
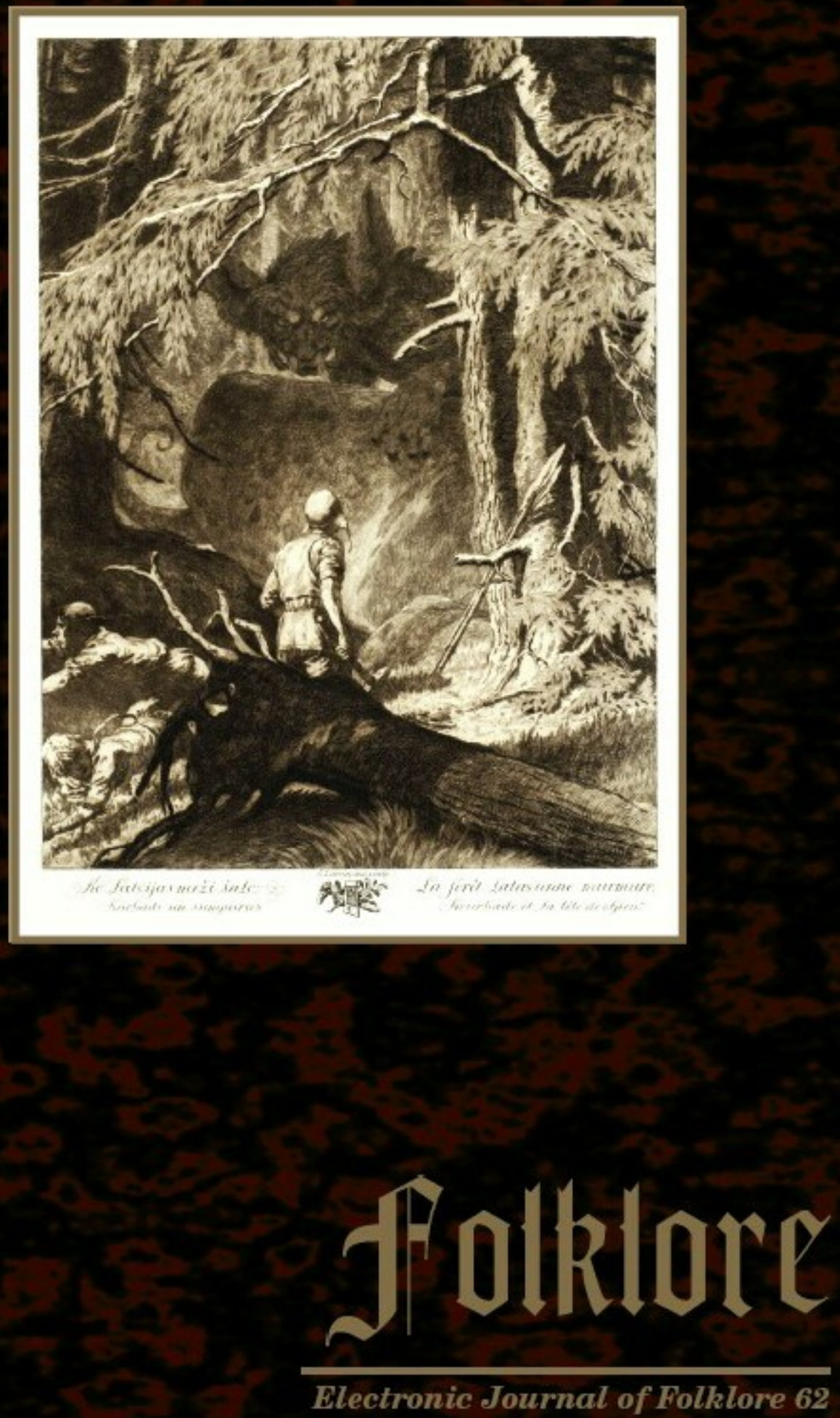


\section{Folklore}

Electronic Journal of Folklore

http://www.folklore.ee/folklore Printed version

Vol. 62

2015 
Folk Belief and Media Group of the Estonian Literary Museum

Estonian Institute of Folklore

\section{Folklore}

Electronic Journal of Folklore Vol. 62

Edited by Mare Kõiva \& Andres Kuperjanov

Tartu 2015 
Editor in chief

Co-editor

Copy editor

News and reviews

Design

Layout
Mare Kõiva

Andres Kuperjanov

Tiina Mällo

Piret Voolaid

Andres Kuperjanov

Diana Kahre

Editorial board 2015-2020: Dan Ben-Amos (University of Pennsylvania, USA), Larisa Fialkova (University of Haifa, Israel), Diane Goldstein (Indiana University, USA), Terry Gunnell (University of Iceland), Jawaharlal Handoo (University of Mysore, India), Frank Korom (Boston University, USA), Jurij Fikfak (Institute of Slovenian Ethnology), Ülo Valk (University of Tartu, Estonia), Wolfgang Mieder (University of Vermont, USA), Irina Sedakova (Russian Academy of Sciences).

The journal is supported by the institutional research funding IUT22-5, the state programme project EKKM14-344, and the Estonian Literary Museum.

Indexed in EBSCO Publishing Humanities International Complete, Thomson Reuters Arts \& Humanities Citation Index, MLA International Bibliography, Ulrich's Periodicals Directory, Internationale Volkskundliche Bibliographie / International Folklore Bibliography / Bibliographie Internationale d'Ethnologie), Open Folklore, DOAJ, C.E.E.O.L., ERIH Plus, Scopus

\section{Editorial address:}

Folklore: Electronic Journal of Folklore

Vanemuise 42-235

51003 Tartu

Estonia

phone: $\quad+3727377740$

fax: $\quad+3727377706$

e-mail: folklore@folklore.ee

home page: http://www.folklore.ee/folklore

All rights reserved

(C) Folk Belief and Media Group of the Estonian Literary Museum

EKM Teaduskirjastus / ELM Scholarly Press

Estonian Institute of Folklore

Authors

Design Andres Kuperjanov

ISSN 1406-0957

doi:10.7592/FEJF2015.62 


\section{CONTENTS}

$\begin{array}{ll}\text { The Revenant on the Threshold } & 7\end{array}$

Elif Boyacıŏlu

Revived Shamanism in the Social Life of Russia

Valentina Kharitonova

The Role of Folklore in the Formation of Latvian Visual Art

Toms Kencis

Children as Prey: A Case of the Utmost. Contemporary Legends

of Organ Theft, Children's Disappearances, Kidnappings, and the Sexual Abuse of Children and Adolescents

Véronique Campion-Vincent

Seeking Borders and Their Mythology in Western Thrace, Greece

Evangelos Avdikos

Walter Anderson's Letters to Joan Amades: A Study of the

Collaboration between Two Contemporary Folklorists

Carme Oriol

Identity Construction in Armenian Music on the Example of Early Folklore Movement

Brigitta Davidjants

Ethnic and Cultural Aspects in the Development

of Kazakh Theatres during the Independence Period:

The Problems of Human Existence

Askhat Mayemirov, Kabyl Khalykov, Bakhyt Nurpeis

Discursive Depiction of Customary Conflict Management

Principles in Selected African Proverbs

Mehari Yimulaw Gebregeorgis 


\section{Discussion}

Scientific Contacts within Ethnology and Folkloristics between Sweden

and Estonia. Personal Experiences and Considerations.

Anders Gustavsson

News IN BRIEF

27th International Humour Conference at Holy Names University,

Oakland, California, June 29 - July 3, 2015. Liisi Laineste

Book Reviews

Mining Corporation and Local Communities in Interaction:

The Case of Batu Hijau. Vladimir Poddubikov

Northern Cultures under the Pressure of Industrial Development.

Dmitri Funk 


\title{
THE REVENANT ON THE THRESHOLD
}

\section{Elif Boyactoğlu}

\begin{abstract}
This study explores accounts of the revenant, the walking dead in medieval Britain through the concept of a failure in the ritual process that surrounded death. This concept is used to explore the rituals leading to, surrounding, and following death, as well as the consequences of their perceived failure. The study of folklore and supernatural beliefs provides a unique insight into the perception of the failed ritual process of death and its consequences, as well as how the community dealt with them. Thus the nature of the revenant and the conditions that lead to its existence as a consequence of a ritual failure will be explored. It is identified as a stagnated presence, divorced from its ritual context, with no foreseeable end. The revenant threatens the community as a whole, be it through physical violence or contagion; it needs to be excised to protect the community and its members.
\end{abstract}

Keywords: Arnold Van Gennep, death, death as ritual process, revenants, rites of passage, ritual failure, stagnated presence, the walking dead, Walter Map, William of Newburgh

\section{INTRODUCTION}

"That the corpses of the dead should sally (I know not by what agency) from their grave, and should wander about to the terror or destruction of the living", would not be remiss in a dark theatre, mesmerising the audience watching with bated breath (Newburgh 1996 [1856]: 658). The vision of a corpse digging itself out of its grave and proceeding to attack those once familiar to it in life was such a strong image that it is still made good use of within the entertainment industry with a whole genre of its own. The thrill of the silver screen aside, however, the quote is from an authentic late twelfth-century historical source. Accounts of revenants were recorded by chroniclers and perceived as intriguing, if worrying curiosities and historically true. As such, the revenant, an interesting topic of study and a vigorous and horrid presence to its percipients, often attracts the attention of scholars who focus on the interaction of the living with the dead. The revenant has been identified as a phenomenon that stands apart from conventional perceptions of ghosts; an unusual grouping of 
dead inhabiting specific anecdotes (Caciola 1996: 15-37; Schmitt 1998: 61-62, 82-83; Simpson 2003: 389-394). Even with only a limited number of revenant anecdotes extant, quite a few academic studies have been produced, varyingly holding light up to the entirety or parts of the spectrum of phenomena, allowing for a clearer picture to be drawn. The narrations of the sources most of the time suggest a prevalent common belief, wherein the percipients, including the victims, are generally aware of the proper conduct and the necessary countermeasures when faced with one of the dead walking.

The revenant was thus, rather than a horrifying exception to the rule, the result of a culmination of specific conditions that allowed it to come forth from its grave. The utilisation of the sources, William of Newburgh and Walter Map, who immediately come to mind where revenants are concerned, is almost a foregone conclusion, as they offer perhaps the most rounded examples of revenant accounts. A few other less familiar sources will be brought into play here as well, but Newburgh and Map have been presented again and again, familiar by now to any that are interested in revenant-lore. This very familiarity is important for the reading and framework proposed in this study, which is a reading of the said phenomena as a consequence of a failure of death as a ritual process. The folkloric approach - that of supernatural belief - allows, it is argued here, for a unique insight into how the failed ritual process of death was perceived and how the consequences for the individual and the community were dealt with. This perspective similarly allows for an unhindered view into consequences perceived as very real by the community that would otherwise remain mythic or theoretical at best, obscuring any possible understanding or reading of the phenomena the way the community experienced it. In a culture where the dead were actually believed to walk, the efficacy and success of the ritual process that was death became of the utmost importance. Dismissing the adverse effects of such failure here as magical, psychological, or imagined would diminish and hinder a direct reading and analysis of the ritual process as perceived by the people of the time.

A clear picture of the revenant and its properties is thus needed to allow for the definition and identification of the conditions that allowed it to come forth. An anthropological approach allows one to read and perceive the phenomena in their entirety, together with their connection to society and its perception of death. It is argued here that if the reading of the revenant as a consequence of the failure in the ritual process of death is indeed applicable, it would indicate that it was perhaps not so isolated a phenomenon as its limited sources from a specific period would indicate, and that the returning presence, in one form or another, was indeed a natural part of the structure that made up the perception 
of death and the process of dying. Indeed, changes in the structure and form of the ritual process that treated death as a threshold from one state to another, as would be evidenced in the Reformation period, would have unavoidable effects on the returning presence, influencing its very nature, manifestations, and motivations. ${ }^{1}$

The revenant-lore, for want of a better name, is in most cases easy to trace within these anecdotes. This lore, it is argued here, was connected to the relations between the living and the dead; relations that were inherent in the social and communal structure, a matter more fundamental than mere organised religion. The revenant was the embodiment of a divergence from a pattern, the failure of a long established and effective process that ensured the continuance of normal communal life when faced with the disruptive forces of death. The revenant represented a most pure example of the consequences of failure in the ritual process that marked the transition of death. It was a presence that struck fear into the hearts of the living, not only through its actions but also through what it represented: the ultimate bad end, stuck between the living and the dead, identified as neither, identity and personality lost, but a corpse with a familiar face. "The exploration of underlying values and the process of evaluation are [---] central issues when studying rituals that have gone wrong" (Hüsken 2007: 339). In other words, how the revenant came into existence, and how the ritual process failed, become equally important questions as they inform us of the community's reaction to the failure and to the existence of the revenant. This in turn tells us about the importance placed on the ritual process itself, the successful integration of the dying person as one of the community's dead, as well as the place of the ritual process in making this transition possible.

In medieval Europe people lived together with their dead, their presence and remembrance very much in evidence in the everyday dealings of the society: "The dead are present among the living" (Oexle 1983: 22). The dead were a veritable age class within society (Geary 1994: 36). In such an environment where the dead existed comfortably in such close proximity to the living, the revenant poses an interesting question by its very existence. What exactly was it that could turn a benign co-existence, which was in all senses expected and the norm, into a source of terror? What was it that called forth the revenant from its grave to haunt and attack the living? 


\section{DEATH AND THE COMMUNITY}

The answer to the question posed above lies in how the community regarded death and the process of dying. Death, biologically an inescapable event, is every living organism's common fate. However, for humanity, "to the organic event is added a complex mass of beliefs, emotions and activities which give it its distinctive character" (Hertz 1960: 27). Death is doubtless the most unsettling event for the human mind to contemplate. This, regardless of the promises of religion and the afterlife, was no different in the Middle Ages. The community, society, and people had no choice but to manage with the existence and proximity of death and the dead.

Thus there were, in the understanding of the times, two basic types of death; the most basic classifications ('good' and 'bad') that human beings bestow upon almost everything are also valid here: "The Good Death is a moral dying, a dying that can be done well or badly as a social performance" (Kellehear 2007: 85-86). The type of death one underwent could very well lead to damnation or salvation, and both of these, as will be discussed below, inherently had both a religious aspect and a social one. Death had to be controlled as much as possible, to follow a pre-set stencil that would indicate and ensure a 'good' death wherein everything was as it should be and nothing deviated from its designated path.

\section{DEATH AS A RITUAL PROCESS}

Control of death was possible through the use of ritual, which would ready both the dying subject and the community for the coming loss: "One of the main functions of ritual is to create and recreate the social and cosmic order [---] as modes of action to cope with disorders such as crises or transitional stages" (Buss 2007: 180). In this sense rituals and ritualisation are indeed strategic acts that are governed by the social situation (Bell 1992: 67). As such, the socio-cultural context becomes inseparable from the ritual itself. Similarly, its purpose is deeply connected to the expected efficacy, social and religious. It constitutes an action with a specific goal to accomplish. A smooth transition in that dual religious and social sense was thus what was sought after when it came to death: "[---] the dead did not cease to be members of the human community. Death marked a transition, a change in status, but not an end" (Geary 1994: 2). However, death was still a break in the normal flow of everyday life, a crisis to be overcome, not only for the individual but also for the community: "Social rituals create a reality which would be nothing without them" (Doug- 
las 1966: 63). Perceived ritual failure could at times bring down disaster upon the community. In the case of medieval death a ritual process was utilised to sooth the upheaval in the community resulting from the loss or expected loss of a member. The term ritual process is used for the period before, during, and after death, and contains a number of rituals with varying aims and properties that contribute to the perception of a successful death. This was primarily a social endeavour, though it employs rituals not only social but also religious in nature, and indeed has influence on the religious/spiritual perception of the fate of the soul as well. "Ritual is consistently depicted as a mechanistically discrete and pragmatic means of sociocultural integration, appropriation, or transformation" (Bell 1992: 16). In this case it was used to transform a dying member of the community into one of the community's dead, so as to allow for continued peaceful coexistence; this was attained not only through the perception of the religious efficacy of the ritual process, but also, and perhaps even more so, through the perceived social efficacy.

Death posed as one threshold that affected the individual as well as the whole community. The schema of the Rites of Passage, first identified in the very early twentieth century by the scholar Arnold Van Gennep, as the rites that marked thresholds in the course of a person's life within the community thus cannot be ignored (Van Gennep 1960). Formed out of the very idea of transition from one stage to another, the schema fits death in the Middle Ages uncannily: "Death relates to life: to the recent life of the deceased, and to the life he or she has procreated and now leaves behind" (Metcalf \& Huntington 1991: 108). The simplified tripartite structure of the schema of the Rites of Passage, while indeed very structural, suits the transitional purpose of the ritual process that surrounded death: "The tripartite scheme persists because it is convenient" (Grimes 2000: 148). It is actually this clear structure that makes this schema an extremely useful tool when dissecting the complex collection of rituals, both secular and religious in nature, that over a period of time aimed to accomplish differing things that all build up to a single result, the transition of death. There are, however, issues that call for caution. For Van Gennep himself the focus seems to be primarily on mortuary rituals; as such his focus perhaps inescapably lay with the living of the society and how they were affected by the death. Death in the Middle Ages, however, started when the subject was alive; it was literally the process of dying; separation from life here is placed before biological death. Thus the folkloric approach with its focus on the dead as a more active party in the process necessitates a careful reading of the utilisation and perceived effects of the ritual process and the rituals it contained, with the dying person as the subject rather than the bereaved. An even more literal approach 
to Van Gennep's theory is proposed here, where the dead are read to have as much faculty as any initiate transitioning from boyhood to adulthood. Thus any failure in the ritual process would initiate a very real perceived danger to the community. This is especially so in the pre-modern era due to the perceived proximity of the dead to the society itself. Death, the inescapable threshold, had specific implications in a society where the dead did not disappear.

Van Gennep subdivided the Rites of Passage into the rites of separation, transition rites or liminal rites, and rites of incorporation (Van Gennep 1960: 11). The theory itself is based on the idea of transition, "which centres on the idea of 'liminality' (from the Latin limen, 'threshold')" (Binski 1996: 29). The Rites of Passage were thus made up of three stages: the separation stage, the liminal/transitional stage, and the reintegration stage. However, as Metcalf and Huntington (1991: 112) warn, Van Gennep's schema remains a vague truism unless one connects it to the values of the culture in question. At the same time, if connected in such a way, it provides insight into the culture's perceptions of death and the ritual process it implements for the transition. The rites surrounding death were concerned first with the life about to be left behind. Hence the resonance is strong with the schema that Van Gennep proposed. This ritual process was in place not only for the sake of the individual though; it was there equally to ensure the continued existence and peace of the community, in overcoming the temporary - even in the case of death - loss of one of its members. A good death gave sufficient warning, allowing enough time for preparations to be completed and the rites to be fulfilled.

In this sense the ritual process that surrounded death was a social event with a single subject at the centre. The dying person, in the best of conditions, would be in the sick bed surrounded by family and neighbours, and be visited by the priest (Wieck 1999: 437; Westerhof 2008: 18). The last rites would be administered and the person would die repentant and absolved. Certain rituals were used to bring about separation and the completion of the ritual process. These rituals were mostly religious in their nature, their source the Church itself. Confession of sins, absolution, and extreme unction - all concerned the salvation of the soul. Within the sick room and the eyes of the community, however, they took on social connotations and came to signify the rituals necessary for the surmounting of the threshold of death. It was in part about readying the member of the community for death, making sure of the readiness of the individual to let go of their previous life and identity. Sudden death and consequent unpreparedness were not only a cause for becoming stuck as a liminal presence, in the transitional phase of the Rites of Passage, between the strata of the living and the dead, but also brought with them suspicion in the eyes of the community and the possibility of the damnation of the individual. The ritu- 
als provided by the Church thus fulfilled double functions, religious and social. The perception created by the ritual process of death thus similarly affected the individual's fate, in both religious and communal terms.

The dying person was encouraged to disentangle all the strands that connected him/her to family, friends, community, society, and the earthly realm. This function was in part fulfilled by confession and absolution, in part by removing any quarrels and exercising forgiveness and thus achieving separation from the community and the current identity of the subject. All ties of affection or enmity were to be discarded. Sins at their very basis were connections to the earthly realm, to family and community that could prove dangerous if left tethered. Geertz describes something similar in a Javanese funeral; emotional distancing is paramount: "[---] it is a calm, undemonstrative, almost languid letting go, a brief ritualized relinquishment of a relationship no longer possible. Tears are not approved of and certainly not encouraged" (Geertz 1973: 153).

In the medieval ritual process the material and economic side of these connections were also considered important and were dealt with through the will and testament; the family that was to be bereaved were taken care of to the best possible extent where the future was concerned, the continuity of the flow of everyday life for the community secured. Any ties, emotional, economical, spiritual, even religious, to those familiar to the dying person, as well as to the community, were cut. Thus this formed the separation stage wherein the subject severed all ties to the community and their identity in preparation for the transition. The subject's own willingness and readiness would play a great role in the perceived success of this stage, as examples given below will indicate.

Binski too, applying the concept of Rites of Passage to the medieval process of dying, and to the rituals surrounding death, indicated that "anointing was the most final ritual statement: the anointing or unction of the dying [---] was a ritually transformative act from which there was no return" (Binski 1996: 29). His concern lay, however, with the ritual process itself and less with the possible consequences of the failure of such a process. Extreme unction was believed to bring about a complete separation from the physical. Its administration to the dying person meant that all hope was abandoned. Extreme unction thus became the beginning of the end of the separation stage in the Rites of Passage that surrounded death. After the administration of extreme unction the subject, "while not literally dead, was considered to have entered a shadow world between life and death, a world of unclear boundaries" (Dinn 1992: 153-154). The subject thus entered the second stage of the Rites of Passage and took on liminal qualities. Survivors after extreme unction, the community believed, were no longer of the living; they were effectively the living dead, outcasts from the living world. They became something other, something liminal that existed 
between the living and the dead: "They would have to live thereafter as a sort of animated corpse" (Duffy 1992: 313), a mirror image of the revenant, one could argue. None of these consequences of course were dictated by the Church; on the contrary, the Church disputed such beliefs, labelling them superstitious and groundless (Thomas 1978 [1971]: 44).

The liminal stage thus commenced during the phase of separation, the deathbed becoming a liminal space that was engaged fully at the point of biological death, when the separation of the dying person from life was complete. The liminal stage, a natural part of the procession of the Rites of Passage that constituted death, and a phase that had to be overcome by both the subject and the community, reflected specific discomforts felt by the community when faced with death. The fear of the newly dead "is something deeply rooted in men's minds, undoubtedly antedating Christianity" (Ellis Davidson 1981: 173). However, these dead would cease to be fearful once they had overcome the liminal stage. Once reintegration was complete, the dead person would become part of the community again under a new identity as one of the community's dead. Similar to the individual dead becoming one of the ancestors (Grimes 2006: 388), here, while individual identity is shed, a collective group is entered, that of the community's dead. Reintegration started with the funeral, the deceased being interred with the others of the community's dead, and was ended, for the most part, either on the seventh or thirtieth day of commemoration after death, these constituting stages of mourning in their own right. The stages of the Rites of Passage - separation, transition, and reintegration - thus provided in death the roadmap for the dying and the dead to follow so as to reaffirm the wholeness of the community even in the face of loss. As such, one can state that the schema of the Rites of Passage is indeed applicable to the much more complex workings of medieval death. It provides a route within the ritual process that the subject going through it takes. The focus here, however, is on what happens when this process fails and is disrupted.

\section{THE REVENANT, LIMINALITY, STAGNATED PASSAGE, AND RITUAL FAILURE}

Revenants thus were the very embodiment of something amiss within this process: the roadmap lost, the subject cast adrift. Revenants were the dead that could not move beyond the liminal stage, and thus inherently personified the very properties of the said stage. The anthropologist Victor Turner, working on the schema of Van Gennep's Rites of Passage, delved further into the concept of liminality, namely the properties of the liminal, threshold phase. It is Turner 
who describes the subjects, while they are in the liminal phase, as 'liminal personae' or 'threshold people' (Turner 1991: 95). These subjects, liminal presences, take on the full meaning of the liminal, the other, that which is isolated and removed from the community, separated but not reintegrated, a source of danger and ambiguity with their lack of identity: "Liminal entities are neither here nor there; they are betwixt and between" (ibid.). In this sense the use of Turner's elaboration of the liminal presence, while self-evident, nevertheless provides a structural shape to what it is that makes the failure of the ritual process as disturbing and dangerous as it was for the community. Where death as a transition from one stage to another was concerned, revenants were by definition beyond the natural order of things; they ended up belonging neither to the living nor to the dead.

"Ideas about contagion can certainly be traced to reaction to anomaly" (Douglas 1966: 5). As such it is not surprising that the liminal personae were also perceived as pollutants, contagious even, poisonous to the whole community, to be avoided at all cost (Turner 1967: 97). However, here too, as the name would imply, the presence is transitional, ephemeral even, the stage has a perceived and foreseeable end. In Turner's approach to the liminal personae the subjects in question are all still within the process of transition, wherein they are being readied for the new state they are to transition into. The only point where Turner tentatively identifies a liminality that is detached from the transitional process is when he is contemplating "the monastic and mendicant states in the great world religions" (ibid.: 107). However, here one has to insert that the "monastic and mendicant states" that are entered into become their own stable and recognised stages. As such, there can be no comparison with the dangerous and uncanny liminal personae cut loose from the ritual process in which they originated. To take Turner's and Van Gennep's theories a step further, the position of the revenant was one of stagnation. Once the ritual process failed, the resultant presence was divorced from its ritual context, and it no longer had a foreseeable end. Thus the revenant becomes not a liminal presence, but a stagnated presence, which displays liminal properties but is no longer transitional or finite. The stagnated presence is thus something incomplete, uncanny, unfinished, and half transformed; that which needs to be excised to protect the community and its members. It is the embodiment of "the fear of those already 'dead' but still reckoned to be a threat to the living" (Davies 2007 [2005]: 131). The reactions this presence provoked from the community, and the countermeasures that were used against it would indicate that this presence, once stagnated, became extremely dangerous, a contagion, the liminal properties amplified: it could not co-exist with the community. While life and death can co-exist, the other, the stagnated presence is in an untenable position. It is 
by its nature destructive and anathema to the society. This would argue that the failed ritual process, at least where death is concerned, is similarly unacceptable and needs vigorous counteraction.

"Most rituals are staged to achieve an end, so there is always something at stake in performances. Because the outcome cannot be known in advance, success and failure [---] are contingent. Ritual is therefore inherently risky" (Howe 2000: 67). The revenant is perhaps the best representation of the consequences of failure and the risk inherent in the ritual process that surrounds death. It is not the mere salvation or damnation of the soul, but the very existence of the social community that is at risk. One could argue that the more vital the ritual for the community, the more dire the consequence of failure. Here, the term failure indicates that the ritual has failed to bring about the expected and hoped for results. There have been theories on the failure of ritual that indicate that it is the performance of the partakers that fails rather than the ritual itself: "[---] a ritual is a divine action; a divine action is divine because it is by definition perfect, therefore no ritual can fail" (Polit 2007: 200). In the case of medieval death, as one shall see, however, there are a great number of conditions that could influence the outcome of the ritual, most of which may be outside of the control of the dying subject.

The failure of the ritual process was first and foremost connected to a 'bad death'. A bad death, as it was understood in the Middle Ages, was a sudden death, one that gave no warning to the dying person, thus no chance for preparation and rituals. The subject would thus face death without any of the rites that would normally ease its way. Sudden, violent, obscure deaths, the death of the traveller alone, out in the wilderness without anyone to bear witness - all were deaths to be avoided if possible. A bad death was thus "the secret death that is without witness or ceremony", a death for which neither the subject nor the community could prepare themselves (Ariès 1982: 11). These people died without receiving the last sacraments and presumably died unconfessed (DuBruck 1999: 24). They were left bereft of rituals, a death uncontrolled and unprepared. "Bad deaths promote disorder", not only as far as the probable fate of the dead person is concerned but also for the community that suffers the said loss (Kellehear 2007: 94). An untimely death was perceived as a primary reason for ritual failure, as there was no opportunity for the ritual process to be commenced properly.

Geertz, again looking at a Javanese funeral, in the aftermath of a rather untimely death of a young boy, identifies the reason for the failure of the ritual to provide the community with closure in the results of social change and social conflict resulting from a discontinuity between the forms of integration of the 
socio-structural and cultural dimensions (Geertz 1973: 164). However, where the phenomenon of the revenant is concerned, it is really impossible, given the nature and the amount of evidence in this period, to speculate, one way or the other, on the effect of any kind of wider socio-structural, cultural, or religious change on the frequency of the perception of failure in the ritual process. As it were, there is little obvious sign of such an effect in the anecdotes. However, as some of the anecdotes shall indicate, while the perception of failure appears to have remained unaffected, there seems to be some correlation between the gradually increasing prevalence of purgatorial ideas and disputes over the kinds of remedies to be utilised against the consequences of such failure.

Within the revenant lore the bad death was one of the main foundations; revenants have almost always died bad deaths. They, unlike the normal dead of the community, refused to stay put in their graves and to co-exist peacefully with the living in the community. They became instigators of chaos within the community, disrupting the community itself. The inability to take their rightful place within the community left the liminal presences as dangerous and uncanny entities in the earthly realm, once familiar and then not familiar strangers. Those that suffered bad deaths could not go through the orderly path of the ritual process; they did not have the opportunity to sever their ties to the living and prepare the community for their loss, be it emotionally, economically, spiritually, or religiously. To this matter of suddenness is also added the common belief that bad people died bad deaths: that the death suffered was indicative of the individual's true nature. This calls forth a link between the failed ritual process and the quality of the individual, in a way that can also be linked to the willingness or unwillingness of the individual to let go of life and the grudges it held.

Thus the ritual process becomes something of a test. Similarly, Howe proposes a reading of the ritual in connection with the inherent risk he perceives in any given ritual: seeing ritual action as a "test, trial, examination" (Howe 2000: 76). The subject thus has to fulfil the conditions of the ritual process, withstanding and passing the test would mean becoming one of the community's dead. The material risk is a community broken by loss, the heirs bereft of economic and parental support. Beneath it, however, is the supernatural risk, not that of damnation - though that too weighted on the relatives - but that of being unable to become one of the community's dead, that is, the proper dead, but to be left as something other, neither living nor dead, something that carried the power to destroy the community utterly, be it through murder or contagion. 


\section{THE STAGNATED PRESENCE AND THE CORPSE}

The folkloric approach allows one actually to trace belief through the believed consequence, the revenant. As belief made flesh, the revenant phenomenon provides a clear narrative as to how the community reacted to the failure of the ritual process and also provides a surprising insight into the consequence of failure and what it indicates about the ritual process itself. It turns out that, at least where death is concerned, once the presence, in the form of the revenant, stagnates and gains independence from the ritual process, existing outside of it, it becomes an untenable presence for the community. It becomes a choice between the community and the stagnated presence. This contradicts how Turner gifted the liminal stage with a certain autonomy from the Rites of Passage (Metcalf \& Huntington 1991: 32). The liminal presence could not be allowed to exist on its own when reintegration within the ritual process was no longer a prospect. As such, when the failure of the ritual process that was death could be identified, pre-emptive countermeasures had to be taken.

The ambivalence of bad deaths and failed ritual processes, which concerned both the eternal fate of the soul and the shaken and fractured community that was left behind, was the most potent factor in the making of the 'suspect' dead, in the creation of the stagnated presence. The suspect dead, when identified, were perceived as potentially dangerous. They were refused burial among the dead of the community, that is, in the graveyard. Suspect dead were thus "condemned to a pitiable existence, since they are never able to enter the world of the dead or to become incorporated in the society established there. These are the most dangerous dead" (Van Gennep 1960: 160). Within the medieval community in Britain most of these dead, with regard to the perceived danger they posed, were buried as far away as possible from the community of the living, as well as from the community of the reintegrated dead: at crossroads, or on roadsides or boundaries. These were places that belonged to no one; they were in a sense liminal themselves, in-between spaces that were to be avoided. This refusal of a proper burial could either be a result of a perceived failure of the subject in the ritual process, or a punishment for crimes against the community, such as excommunication or suicide. Thus the reaction of the community could be gauged by the place of burial: "The sanctified ground in the churchyard was contrasted with the limbo of evil spirits at the crossroads" (Parker Pearson 1993: 207).

However, it was not only the place of burial but also what the living did to these corpses; these dead were mutilated. The living would sometimes stake the corpse into the grave; remove the head and place it between its legs or bury it separately; crush the head after decapitation; crush the body under a heavy boulder; remove the legs; bury the corpse deeper than usual; throw some into 
bogs or rivers, or bind the hands and feet (Reynolds 1998: 8-9; Simpson 2003: 390). Some were buried face down (Gordon \& Marshall 2000: 7). These burial practices were not novel in nature; such burial sites were discovered at the Anglo-Saxon cemetery of Sutton Hoo, and at other archaeological sites as old as the Iron Age (Barber 1988: 79; Carver 1998: 138-9; Daniell 2007: 118). These seem to indicate that the need and urge to practice such gruesome customs on some of the dead had long existed, divorced from any specific religion or even region.

These dead, by having failed the ritual process of death, and to some extent by the impossibility, inability, or unwillingness of the community to bury and reintegrate them properly, were condemned to remain as stagnated presences. In the eyes of the community at least they were clearly a source of danger that had to be dealt with before things got out of hand: "They would like to be reincorporated into the world of the living, and since they cannot be, they behave like hostile strangers toward it" (Van Gennep 1960: 160). The community, when it could identify a failure in the ritual process, aimed to make the corpse stay put in its grave, a sinister indication that the body, the corpse itself, was perceived as a source of danger, a threat.

In the minds of the members of the community, the existence of revenants was first and foremost connected to the dead body left behind, as it was the activity of these physical bodies that set apart these particular stagnated presences. The body, after death, was believed to retain a certain essence of life, which made it a possible threat for a certain period of time, until the complete decomposition of the flesh. This perceived suspect period concerning the body is also connected, in a sense, to the Rites of Passage, though this particular theory belongs to Robert Hertz. Hertz studied the practice of two-fold funerals, which indicate a two-staged death, in certain near-contemporary communities of Indonesian people, particularly in upriver Borneo (Hertz 1960: 28-29). The person effectively dies twice. The first death is the biological death, which leaves behind the fleshy remains, upon which the corpse is interred temporarily and is regarded as liminal and dangerous, indicative of a liminal ambiguous period, wherein the community has to guard against the newly dead. During this time, "it 'returns' of its own initiative through necessity or through malice, and its untimely appearance spreads terror" (Hertz 1960: 37). This period is believed to end only after the complete decomposition of flesh, whereby the body dies its second death, which indicates the safe passage of the dying person into the community of the dead (Barber 1988: 141). The remains at this point are dry remains, mere bones, and are once again, and this time permanently, interred in their final resting place. Van Gennep similarly points to this connection between the flesh and the transitional period during his discussion of funerals 
(Van Gennep 1960: 148). This perception was equally true of the medieval revenant: "The question of a reanimated skeleton is never raised: there must be flesh upon the bone" (Caciola 1996: 32).

For Hertz's subjects, the danger of the dead harassing the living during that particular period seems to have existed for all the dead, as long as they were in this in-between stage wherein the corpse remained intact, a kind of normal liminal phase one could say. However, those that had died bad deaths were perceived quite differently: "It seems, in the most typical cases at least, that the transitory period extends indefinitely for these victims of a special malediction and that their death has no end" (Hertz 1960: 85). Thus, if one combines the perception of the condition of the corpse with the failed ritual process of death, it explains why the intact body featured so heavily in the revenant lore. These stagnated presences were thus pushed outside even of the dominion of nature, rejected by the very soil. They did not seem able to decompose and follow the natural order of things.

Literally trapped between the living and the dead, due to their failure of the ritual process, the revenants walked the earthly realm in their own bodies; they refused to remain in their graves and roamed places familiar to them. They were, in a sense, horrible imitations of the life they had lost. Previous attachments still seem to guide and motivate the revenant, as most of the time their targets are familiar people, loved ones, the bereaved. One argument may well be that the revenant in its own violent way seeks to remove the attachments that the failed ritual process had left behind, or to take these very people with it to the grave. The living have no way of peacefully mitigating the situation, as the revenant seems to act under motivations that have nothing to do with the personality of the living person before their death. They thus become an abomination to the community, estranged members that nevertheless cannot be separated from their previous roles as loved community members, but are lethal monsters nonetheless. The dead in question seem to be warped by the failed ritual process. They are the 'hostile strangers' (Van Gennep 1960: 160). Attachments in this case become a source of danger for the living, no longer a point of comfort. The revenants thus represented the very thing the community would hope to avoid by the ritual process that surrounded death. 


\section{EXAMPLES OF THE STAGNATED PRESENCE IN ITS REVENANT INCARNATION}

The graphically described revenant has been captured in the pages of twelfthand early thirteenth-century chronicles, allowing a glimpse into its nature. William of Newburgh, Walter Map, Geoffrey of Burton, the anonymous recorder of the Lanercost Chronicle, all spared attention and time to record these entities. They were baffled at times by the reports they heard of revenants, but did not doubt their authenticity. William of Newburgh, in his Historia rerum Anglicarum, indicated that there was an abundance of examples, perhaps linked in Newburgh's mind to apocalyptic concerns, but in general his anecdotes seem to be cautionary in nature, providing an insight into revenant lore and the perception of the liminal presence within the community (Newburgh 1996 [1856]: 658).

The following anecdote is, as are the others, set only a few years prior to Newburgh's writing. In a monastery at Melrose a revenant makes its presence known. He is identified as a chaplain of an illustrious lady, buried in the said monastery. The circumstances of the man's death are left unclear. However, suspicion is cast upon him through his way of life, which it turns out is indicative enough: "After his death - as the event showed - the guiltiness of it was brought to light" (ibid.: 658-659). As such one can understand that revenancy was perceived as indicative of a bad life. Here surfaces the link between the failure of the subject in its ritual process and the perceived quality of the said individual and the kind of life they had lived, the ritual process becoming a trial that the subject had failed. The haunt of the revenant, as prescribed by liminality, is a ground familiar to him. After an attempt at hounding the inhabitants of the monastery, the revenant turned its sights on its former mistress; previous attachments, still unbroken, were at play.

The degeneration of the stagnated presence from one of the community's dead, albeit one that had lacked morality in life, to a danger, is indicative of the transformation undergone by the Melrose revenant. It does not communicate nor would it seem that any interaction would benefit the living. The revenant's end comes in a physical altercation wherein a brother of the monastery "struck the axe which he wielded in his hand deep into his body" (ibid.: 659). The presence seems vulnerable to physical attack, retreating back into the grave once wounded. The corpse was dug up and, "having carried it away beyond the walls of the monastery and burnt it, they scattered the ashes to the winds" (ibid.). The complete destruction of the corpse is the way to divest the community of this unwanted stagnated presence. It seems that it does not matter whether the setting is a monastery or a village; the way to deal with a stagnated presence walking in its own body was through the destruction of the corpse. 
Newburgh's revenant at Berwick on Tweed displays similar properties, though the consequences for the community were even direr. A revenant wandered forth from his grave in the town. The man, though wealthy in life, was proven to have been a rogue in the eyes of the community through his postmortem actions (ibid.: 657). The danger posed by this stagnated presence to the community engenders a communal response, a meeting of sorts. Communal solidarity seems to be one reaction towards such presences; the community in some cases clearly banded together to deal with the problem. The threat was not limited to physical altercations, as had been the case in Melrose. The wiser members of the community were aware that a speedy solution to the situation was necessary, or else "the atmosphere, infected and corrupted by the constant whirlings through it of the pestiferous corpse, would engender disease and death to a great extent; the necessity of providing against which was shown by frequent examples in similar cases" (ibid.: 657-658). The presence was believed to be able to infect and corrupt the very air, the very community. The stagnated entity here was present in all its glory.

It was capable of physically laying hands on the members of the community, beating them black and blue, threatening their very lives (ibid.: 660). At the same time its contagious nature presented a wider threat to the whole community. As with Turner's liminal personae, this presence was perceived as contagious, a pollutant; the revenant seen as a source of plagues. However, unlike the liminal personae, the revenant is there to stay. With its unclean presence due to the failed ritual process and its inability to become one of the dead of the community, and thus an outsider, it became a pollutant that had to be removed. The offhand reference to other such happenings, where indeed the pollution of the stagnated presence had proved harmful to the community and its members, indicates that the belief was not uncommon. Similarly, the countermeasures taken against the revenant seem to come from a community well-versed in how to deal with such occurrences. They dig up the body and, "having cut it limb from limb, reduce it into food and fuel for the flames. When this was done, the commotion ceased", though the remedy seems to have been too late, as "a pestilence, which arose in consequence, carried off the greater portion of them" (ibid.: 658). This rather bleak ending would seem to ratify the 'wiser' opinion that all haste is necessary when dealing with the stagnated presence.

In response to the revenant's walking, the community at Berwick took physical action as in the Melrose example. The countermeasure of dismemberment and the complete destruction of the body through fire came from the community. It seems the very connection of the returning dead to the community - the corpse - had to be destroyed to rid the community of this unwanted 'stranger', 
the community thereby closing its ranks and boundaries to further invasion. This destruction may well be read as a complete refusal of reintegration, and at the same time a forceful and final separation of the presence from its original community and any vestiges of identity. As previously mentioned, the stagnated presence thus divorced from its ritual context cannot be allowed to exist if the community is to survive.

Newburgh continues with another anecdote that underlines the rather sinister properties of the revenant, this time located at a castle called Anantis (ibid.: 660). ${ }^{2}$ The man's position in life is made clear at the very beginning. $\mathrm{He}$ was already a rather disreputable sort, having come to this particular castle to escape a shady past and, according to Newburgh, still embracing his 'evil propensities'. Trying to catch his wife in the act of adultery, the man fell from the beams of his bedroom, where indeed the wife was engaged in the said activity. Though the man did not die immediately with the fall, the fall opened the path for his death, and his failed ritual process. The circumstances of his situation were all around unsavoury, the results even more so.

A priest was called for the man who was lingering on death's doorstep. The priest "admonished him to make confession of his sins, and receive the Christian Eucharist in proper form" (ibid.: 660). The man, however, preoccupied with his wife's unfaithfulness, did not confess or receive absolution. He "put off the wholesome advice until the morrow - that morrow which in this world he was fated never to behold" (ibid.: 660). One would deduce from this that he refused to undergo the last rites, or extreme unction; he wilfully refused to partake in the ritual process, unable to let go emotionally, spiritually, and religiously. This, added to his rather misspent life, made the man a perfect candidate for revenancy.

This particular man provides the very representation of a bad death: a ritual process that was almost wilfully failed. Even though he seemed to get a second chance of putting his own death in order, he did not take it. It could thus be argued that the state of mind of the dying, if there is indeed time for consideration, is of utmost importance to the success of the ritual process. The subject undergoing the process is perhaps the most influential factor in the whole process. The Christian burial, an attempt at reintegration, was unsuccessful. Like the Melrose revenant, one would assume, he was given proper burial rites, but this only emphasises the importance placed by the community on the ritual process itself.

Once the dead man walked, the main concern of the community at first was an attempt to isolate themselves physically from the stagnated presence, the revenant, by locking themselves in their houses. Their first fear was the physi- 
cal aspect of the revenant. However, as is generally the case with stagnated presences, something much more insidious was working its way through the community.

For the atmosphere, poisoned by the vagaries of this foul carcass, filled every house with disease and death by its pestiferous breath. Already did the town, which but a short time ago was populous, appear almost deserted; while those of its inhabitants who had escaped destruction migrated to other parts of the country, lest they, too, should die. (ibid.: 660)

Thus a single stagnated presence, left to its own devices, was enough to destroy a whole community; the ties of the community unravelled due to the threat represented by continued deaths and emigration.

In the end, two young men took it upon themselves to rid the town of the presence. Their idea of a remedy was similar to the previous cases: the mutilation and complete destruction of the body. They dug up the body and "then, dragging it beyond the village, they speedily constructed a funeral pile" (ibid.: 661). The fact that the people were eager to remove corpses from the community's space, even for destruction, is telling. All traces of the presence, even of its destruction and destroyed remains, were to be exiled. In this anecdote there is the added detail that they remove the heart and shred it to pieces to allow the body to burn: "this being torn to piecemeal, and the body now consigned to the flames" (ibid.: 661). The successful destruction of the stagnated presence brings immediate relief to the community: "When that infernal hell-hound had thus been destroyed, the pestilence which was rife among the people ceased" (ibid.: 661).

The Anantis revenant is perhaps the best example of the revenant as a stagnated presence that had incorporated the properties of a liminal presence, as Newburgh gives the most detail on the man before, during, and after his death, and on the rites that were supposed to be performed. This allows one to see how the ritual process had failed and had even deliberately been compromised by the man himself, as well as the consequences thereof. This would indicate that the two revenants cited earlier did go through the normal religious rituals surrounding death; the failure of the ritual process was literally the failure of the individual to let go and separate itself from the life it was to leave behind. Here again surfaces the perception of the ritual process as a trial, a test for the subject to pass. The fact that the narration of the Melrose and Berwick anecdotes puts more emphasis on the type of life that these men had led, rather than their deaths, is also of interest. The fact that some revenants seem to have been buried initially among the dead of the community indicates that, at 
first, their deaths, their ritual process, had been perceived as formally fulfilled. In such cases it is the revenant, the stagnated presence walking, that clearly identifies the actual failure of the ritual process. The 'badness' of their death, the failure of their ritual process, was thus rooted in their inability or unwillingness to let go. It is perhaps important to indicate that the ritual process, while it encompassed the rituals surrounding death, proposed by the Church and used by the community, was not limited to the physical rituals alone. As it were, the ritual process was literally a journey for the individual to undertake, fraught with dangers, the possibility of failure always there. Hence it was not only circumstance and fate that created the framework for a bad death and the failure of the ritual process, but it was also deeply rooted in the individual's own preparedness. As such, the folkloric approach provides its own evidence of ritual failure; the very existence of the revenant is what marks the ritual process as failed and one is brought face to face with the direct consequence of such failure.

Another anecdote shares many common points with that of the revenant of Anantis. It was recorded in the first half of the twelfth century, thus relatively early, by Geoffrey of Burton in his Life and Miracles of St Modwenna, but set considerably earlier, during the period 1085-1094, when Geoffrey Malaterra was abbot of Burton (Burton 2002: xxix). While, in the study of the walking dead, saints indeed present difficult issues too tangled to discuss here, this particular anecdote is worth discussing. It is recorded in the section of the book on posthumous miracles, wherein the author recorded local beliefs that were in any way connected to the shrine where the bones of the saint were supposedly at rest.

It concerned two revenants rather than one. These two runaway peasants had caused an inordinate amount of trouble for the abbey, and were suddenly struck down dead. As one can guess, it was this point that tied the anecdote to the saint; it was deemed as just punishment, though the saint is not mentioned at all. The two peasants were buried in the churchyard but were then seen, "while the sun was still up, at Drakelow, carrying on their shoulders the wooden coffins in which they had been buried", almost as if they had been expelled from the churchyard, coffin and all (ibid.: 195-197). The peasants then started to display the notorious properties of the stagnated presence, wandering around, calling out to people. However, it was not physical violence that threatened the community so much as illness: "Such a disease afflicted the village that all the peasants fell into desperate straits" (ibid.: 195-197). The polluting presence of the stagnated entities had poisoned the village.

The threat that the entire village might perish prompted three brave men who were still healthy to take action, at the very least to save themselves. They 
went about it in the traditional way, targeting the bodies of the revenants: "They received permission from the bishop to go to their graves and dig them up" (ibid.: 197). That the bishop granted his permission seems to indicate that in such situations opening the grave and dealing with the corpse was the normal thing to be done. That there were graves to dig would seem to indicate that the corpses were still in the churchyard. Having found the corpses intact, rejected, it seems, by death itself, "they cut off the men's heads and placed them in their graves between their legs, tore out the hearts from their corpses, and covered the bodies with earth again" (ibid.: 197). The hearts, as in the Anantis case, were treated to a special fate and burned, and while an evil spirit was described to have flown out of the hearts, there was no talk of purification, prayers, or the saint. While the runaways' original 'bad death' might have been linked to their offences against the saint, the remedy for the revenancy lay with the community taking familiar action.

The corpses, typical of the restless dead, were found intact, the period identified by Hertz as most dangerous. Thus it seems that in the case of the revenant the normal procession of death and decomposition was halted, had literally stagnated, through the sudden death and the implied failure of the ritual process, and the consequent continued existence of the dead as a revenant. The bodies of those that die bad deaths, those that fail the ritual process, "inspire the most intense horror and are got rid of precipitately; furthermore, their bones are not laid with those of other deceased members of the group who have died a normal death. Their unquiet and spiteful souls roam the earth for ever" (Hertz 1960: 85).

In Christian society, the cemetery was to be off-limits to the suspect dead. The mis-burial of the two culprits is the first statement made. The anecdote also reinforces the idea that "the fate of the soul was linked to that of the corpse", both in burial, it seems, and in its actual condition (Finucane 1981: 60).

The precautions that the peasants take with the decapitation and the placement of the head are very familiar, though in this study this is the only example - and thus doubly important - in that it actually connects this specific burial custom with revenants, whereby it could be argued that, where such graves are found unexplained, it may indicate both precautions against suspect dead, and, to a lesser extent, remedies in the face of such restlessness. The very matter-of-fact actions of the peasants indicate that they were no strangers as to what remedies were to be effective. In the end the sick peasants recovered, and everyone left Drakelow. This anecdote provides the best evidence of how a stagnated entity was capable of destroying a whole community. The stagnated presence, outside of its ritual context, endangers the whole community. The 
perceived danger, which is emphasised through the consequences recounted in the anecdotes, underlines this fact. Similarly, the removal of the presence after destruction allows no leeway for reconciliation of the presence with either its former identity or its proposed identity as one of the community's dead, one of the ancestors, so to say. Thus, where death is concerned, the liminal presence cannot be allowed to exist independently of the ritual process that gave birth to it.

The previous anecdotes stress the otherness of the stagnated presence, both where the personality of the dead person is concerned, but also the threat the revenant posed to the community. The members of the communities do not seem to be in any way surprised that the revenant is the reason for sustained death and destruction within the community, and they are ready to act in order to stop it. No one seems to need a manual on how one is to deal with such occurrences. However, the next anecdote, from Newburgh's Historia, introduces a different aspect to the whole idea, the hint of a possibility that something else could at times be a viable option when one is dealing with a stagnated presence.

Newburgh's Buckingham anecdote represents the most positive outcome of all his anecdotes, as well as the only one where the effectiveness of clerical measures seems to put the divine and the Church to the fore. The story begins similarly to the others: a man died and refused to stay put in his grave. The night after burial, "having entered the bed where his wife was reposing, he not only terrified her on awaking, but nearly crushed her by the insupportable weight of his body" (Newburgh 1996 [1856]: 656). In this rather horrifying imitation of life, the wife got a healthy scare rather than physical injuries, but decided to surround herself with other people to avoid a repeat of the situation. Consequently, the revenant moved on to approach his brothers. Thus his points of interest and interaction were all those who were once closest to him in life.

As with the other anecdotes, the community seems to have come together in the face of this invader and at long last went to the Church for advice. The Bishop of Lincoln, fascinated by the story, decided to look closer into things; some of his companions indicated that commotions like this were common in England and "that tranquillity could not be restored to the people until the body of this most wretched man were dug up and burnt" (ibid.: 657). Thus the normal remedy to a stagnated presence, a revenant walking, was immediately suggested. As was the case with the Melrose monks, the general knowledge of how to get rid of such a danger to the community, whether it was subscribed to or not, was far from limited to the vulgar and ignorant, though the narration seems to suggest that the bishop himself, the Burgundian-born Hugh of Avalon, is unfamiliar with it, which may explain to an extent why, in this anecdote, the 
bishop veers off the beaten path. This deviation, one could argue, may also well flow from a change that was already underway, something that would change the perception of the stagnated presence and the consequences of a failed ritual process. These changes, the effects of which would become more apparent further down the line, were brought on primarily by the emergence and spread of more clearly elaborated purgatorial ideas. These were to introduce the possibility of change to the religious and social status of the 'dead', of reintegration even of the revenant, allowing the living to have a role in this possibility. The bishop thus had other ideas as to how to approach this dead man walking: he "addressed a letter of absolution", which was then placed into the opened grave wherein "the corpse was found as it had been placed there" (ibid.: 657).

The body, as was the case with other revenants, had remained untouched by decomposition, a good indication of stagnation and revenancy, where "the cadaver [---] was condemned not to decompose in the ground" (Schmitt 1998: 200). The surprising thing in this anecdote would be that the letter actually worked, absolving the victim of whichever crimes and sins and thereby completing the separation phase of the dead man, albeit post-mortem, thereby ending his stagnation. The reburial or closing of the grave would then represent the onset of the reintegration stage. Thus the man rested, at last completing his ritual process successfully, albeit after a terrifying detour. However, there are a few important points one must emphasise while taking into account this success. Unlike other revenants and stagnated presences, this revenant claimed no victims, either through lethal physical assault or contagion. This lack of pollution may have been why the bishop deemed this particular man worthy of salvation, or at least helped him come to this conclusion. All in all, the dead man's worst effect on the community was terror, sleepless nights, and the disruption of daily life. As such he was much less of a threat than the others. It may have been this moderation that specified this particular revenant as salvageable.

Walter Map too reserved a place for revenants in his De Nugis Curialium, believed to have been written in stages between about 1181 and 1192 (Gransden 1996: 243). Three such revenant anecdotes are of interest here, in the first of which, in contrast to Newburgh's Buckingham anecdote, the advice of a bishop went awry. An English knight by the name of William Laudun came for help to Gilbert Foliot, Bishop of Hereford (bishop 1148-1163). William's problem was a dead Welshman, who had died in an unchristian manner, one would guess without last rites, suggesting a bad death, and failed the Rites of Passage. The Welshman was wandering from his grave and calling out the names of people of the village, "who upon being called at once fall sick and die within three days, so that now there are very few of them left" (Map 2002: 202-203). 
Here, unlike in the previous case, the revenant was aggressive, even if not physically, and infectious, dragging its victims away from life itself and almost completely eradicating the community. The bishop's conclusion was that there was a divine struggle at work. To remove the evil angel, he advised that they "let the body be exhumed, cut the neck through with a spade, and sprinkle the body and the grave well with holy water, and replace it" (ibid.: 202-203). Unlike the bishop in the Buckingham anecdote, Gilbert Foliot did make some concession to the common belief that the remedy for such presences involved at least a measure of dismemberment - the cutting of the neck - if not the complete destruction of the body. His other remedy was more spiritual, but did not point to a troubled soul in the afterlife, as the Bishop of Lincoln's response had, but rather to the role of evil spirits, demons, against which holy water would be thought effective, a purification in any case. The Bishop of Hereford's recommendations, however, failed to have an effect on the revenant. When William Laudun had his own name called by the revenant, he was forced to take action the old-fashioned way. He went on the counter-offensive, chasing the presence back to its grave where he "clave his head to the neck. From that hour the ravages of that wandering pestilence ceased" (ibid.: 202-203). The rather more rigorous attempt at damaging the body of the revenant seems to have worked. However, whereas in Newburgh's accounts, the more physical response to revenants was successfully adopted in all but the Buckingham anecdote, in Map's collection of revenants the Herefordshire revenant's violent end was the exception.

A pattern similar to that of Newburgh's Buckingham anecdote is followed in Map's next anecdote. In this, "a man, reported to have died unchristianly, for a month or more wandered about in his shroud both at night and also in open day" (ibid.: 204-205). The neighbourhood then came together and trapped him in an orchard. That they allowed the presence to roam for a month before taking action is telling. It seems that this one, as in the case of the Buckingham revenant, was relatively harmless to its surroundings and the community. There are no reported victims, and once again no contagion. The Church, through the agency of Roger, Bishop of Worcester (bishop 1163-1179), is apparently called in to help: "Roger ordered a cross to be laid upon the grave of the wretch, and the man himself to be let go" (ibid.: 204-205). Again, it may have been the lack of victims or the perceived nature of the dead man that made the bishop's advice acceptable in this case.

The laying of the spirit here needed no destruction or removal; rather it seems to indicate reintegration, the return of the formerly stagnated presence to its proper place among the dead of the community. The raising of the cross 
may well suggest that a proper ritual process had been denied to the man the first time around, and that by the order of the bishop the reintegration stage was to be recommenced and completed at this later date. Once the revenant was in the grave and the cross was raised on top of it, "he remained quiet" (ibid.: 204-205). As such, a post-mortem change in the affairs of the living and the dead had thus been effected, very much as in the Buckingham case.

Map's final anecdote is similarly constructed and the change from the threatening revenants that needed violent and extreme measures is clear. It concerned a knight and his late father. The dead man on his return was very articulate and once he convinced the son that he was indeed his father, he asked for a priest to be called (ibid.: 206-207). His demeanour was not threatening and he was actually communicating with his son rather than attacking him as would have been the norm. His actions seemed to inspire pity rather than fear; he was in dire need of something only the living could offer, being very clear as to what, or rather whom, it needed: "I am that wretch whom long since you excommunicated unnamed [---] I am permitted to ask for absolution" (ibid.: 206-207). The man had died excommunicate, and as such was a prime example of a failed ritual process. The subject is, in a sense, exiled and isolated from the community even while alive, a condition which continued on into death. That he was excommunicated anonymously may indicate that the community, even conceivably the man himself, was not aware of his condition until it was presumably too late. This would perhaps argue that such a person, already marked out for stagnation, could not benefit from the normal flow of the religious rites and the ritual process in general, which, even if carried out normally, would be doomed from the start.

How was it then that this man could return, in possession of his faculties, and ask for the correction of the ritual process, when the stagnated presence should have been the embodiment of hostility for the community? It is the revenant himself that gives the answer: "The common prayers of the Church and the alms of the faithful have by God's grace so helped me" (ibid.: 206-207). It seems the living had thus accomplished something previously unattainable for a stagnated presence: they had influenced the very nature of this revenant, and allowed him to return in a fashion that would, rather than lead to complete destruction and an eternal lack of reintegration, attain the very opposite, a post-mortem absolution, that would allow the man to be reclaimed as one of the community, as one of the community's dead: "So being absolved he went, with a great train of people following, to his grave and sank into it, and it closed over him of its own accord" (ibid.: 204-205). 
The man thus is reinterred and reintegrated among the dead with many witnesses including the local community. Map states that "this new case has introduced a new subject of discussion into the books of divinity", emphasising that the event and the story had implications for the afterlife and the fate of the soul, and for the stagnant dead and their relationship to the community, which were as yet novel and unexplored (ibid.: 206-207). This anecdote again provides a strong example that the more elaborate purgatorial ideas were becoming more prevalent.

Roughly contemporary, De Nugis and Historia, with their differing ratios of destroyed or dismembered revenants to those revenants who were saved or reintegrated, suggest that both outcomes were present in that period and of interest to the writers. Stagnated presences were undergoing a change, becoming more talkative for one, and aware of their own motivations. They could now communicate these motivations to the living, and it seems they were becoming less lethal, if not less disturbing, for the community. This change, however, was not in any way uniform, nor does it seem linear, as would be indicated by an anecdote from the Chronicon de Lanercost, the relevant part of which, concerning the late thirteenth century, seems to have been written by a Franciscan friar (Stevenson 1839: iii-iv). In Clydesdale, south-western Scotland, a man who had "lived wickedly and died most wretchedly" and had also been excommunicated, returns, physically assaulting people, and ends up killing the son of a knight (Stevenson 1839: 163-164; Maxwell 2001 [1913]: 118-119). This source, while relatively late, still seems to retain intact the idea of the uncommunicative, violent, even deadly revenant. It may also argue, together with the properties displayed by the more peaceful revenants recounted here, that the perceived quality of the individual in life may also have affected the way the revenant acted and its possibility of reintegration and salvation.

\section{CONCLUSION}

The successful reading of a belief such as that in the revenant through the anthropological concept of failed ritual process, and its resultant identification as an embodiment of the stagnated presence, provides a framework that explains why such phenomena exist, in context with the community and society in which they surface. On the other hand, the study of the revenant also holds up a mirror to the anthropological approach itself. As it were, the very nature of the revenant as a stagnated presence, as well as the anecdotes about revenants, seem to indicate that the transitional-liminal presence can only be 
tolerated by the community as a finite part of the transitional ritual process. Once independence is declared through failure of the ritual process, the subject, the stagnated presence, the other, is no longer a tolerable presence. Only complete destruction of the presence can remedy the situation and salvage the community. Similarly, this framework, while allowing for the revenant to be identified as a stagnated presence, a transitional stage out of its ritual context, provides a broader perspective that indicates that the precise form of that presence was forged through religious and other cultural developments that were open to change.

Newburgh's Buckingham revenant and Map's Worcestershire revenant, as well as the latter's account of the knight's father, and the treatment these particular stagnated entities received, herald ideas that were to become more prevalent, bringing with them change: "We can detect in the ghost stories of the chronicles an intensifying desire to reinterpret the returning dead as souls in need of aid" (Watkins 2009 [2007]: 185). However, the potency of liminal properties and the stagnated presence should not be underestimated. Not all revenants seemed to wish for or were even capable of wishing for reintegration and salvation. As the Clydesdale revenant indicates, the change in ideas and the penetration of new ideas into popular belief may well have been decidedly patchy.

Just before focusing on the 'doctrine of purgatory' under its own heading, Jacqueline Simpson, noting the disappearance of the revenant from British legend, states: "This change may well be due to the more spiritual theology of Purgatory" (Simpson 2003: 394). One can argue that what changed the revenant was less the doctrine of purgatory itself, and more the spread of purgatorial ideas. These implied that post-mortem intervention and alteration of the circumstances of the dead were possible, but not all of them corresponded to a set doctrine. These ideas would translate into the possibility of the reintegration of the lost stagnated presence into the community as one of the dead.

Revenants for a time had been the very embodiment of the stagnated presence, an offshoot of the liminal presence with all its inherent properties: the way they came into existence and the way they interacted with the living of the community; their behaviour, as well as the actions the community took against them, both preventative in nature and as countermeasures after their walking. However, as factors such as the effectiveness of purgatorial ideas changed the society and community, as well as the course of the ritual process and the perception of its failure, stagnated presences were hesitantly starting to go through their own metamorphoses. They seem to become less dangerous, less physical in their attacks; they start to speak, and make sense; their 
motivations become comprehensible to the living, allowing them a way to help, to try and repair failed ritual processes that had previously presented an irredeemable situation. Their dangerous properties and stagnated position were tempered by the possibility of a happy end. The reasons for the existence of the stagnated presence, the failed ritual process, however, would remain as valid as ever. Thus the stagnated presence stubbornly remained within the workings of the community, even while the revenant, once its perfect incarnation, violent and deadly, seemed to be gradually disappearing, leaving its place to another form. The ritual process could still fail and this failure would continue to spawn stagnated presences.

\section{ACKNOWLEDGEMENTS}

This article and indeed the dissertation it originates from would never have been completed without the endlessly patient support of my supervisor Dr Paul Latimer.

\section{NOTES}

1 Further research on this subject, the effects of the Reformation period on the returning dead and their manifestations, form part of my ongoing doctoral work.

2 Joseph Stevenson proposes this castle to be Annand or Annan, in Dumfriesshire (Newburgh 1996 [1856]: 660).

\section{REFERENCES}

Ariès, Philippe 1982. The Hour of Our Death. Transl. by Helen Weaver. New York: Vintage Books.

Barber, Paul 1988. Vampires, Burial, and Death: Folklore and Reality. New Haven: Yale University Press.

Bell, Catherine 1992. Ritual Theory, Ritual Practice. Oxford: Oxford University Press.

Binski, Paul 1996. Medieval Death: Ritual and Representation. Ithaca: Cornell University Press.

Burton, Geoffrey of 2002. Life and Miracles of St Modwenna. Transl. and edited by Robert Bartlett. Oxford: Clarendon Press.

Buss, Johanna 2007. The Sixteenth Pinda as a Hidden Insurance Against Ritual Failure. In: Ute Hüsken (ed.) When Rituals Go Wrong: Mistakes, Failure, and the Dynamics of Ritual. Boston: Brill, pp. 167-182. DOI: 10.1163/ej.9789004158115.i-377.57. 
Caciola, Nancy 1996. Wraiths, Revenants and Ritual in Medieval Culture. Past and Present, Vol. 152, pp. 3-45. Available at http://www.academia.edu/9133076/ Nancy_Caciola, last accessed on September 17, 2015.

Carver, Martin O. H. 1998. Sutton Hoo: Burial Ground of Kings? Pennsylvania: University of Pennsylvania Press.

Daniell, Christopher 1997. Death and Burial in Medieval England: 1066-1550. London: Routledge.

Davies, Douglas J. 2007 [2005]. A Brief History of Death. Malden: Blackwell Publishing.

Dinn, Robert 1992. Death and Rebirth in Late Medieval Bury St. Edmunds. In: Steven Bassett (ed.) Death in Towns: Urban Responses to the Dying and the Dead, 100-1600. London: Leicester University Press, pp. 151-169.

Douglas, Mary 1966. Purity and Danger: An Analysis of Concepts of Pollution and Taboo. New York: Routledge.

DuBruck, Edelgard E. 1999. Introduction. In: Edelgard E. DuBruck and Barbara I. Gusick (eds.) Death and Dying in the Middle Ages. New York: Peter Lang Publishing, pp. 1-28.

Duffy, Eamon 1992. The Stripping of the Altars: Traditional Religion in England, 14001580. New Haven: Yale University Press.

Ellis Davidson, Hilda R. 1981. The Restless Dead: An Icelandic Ghost Story. In: H.R. Ellis Davidson (ed.) The Folklore of Ghosts. Cambridge: St. Edmundsbury Press, pp. $155-176$.

Finucane, R. C. 1981. Sacred Corpse, Profane Carrion: Social Ideals and Death Rituals in the later Middle Ages. In: Joachim Whaley (ed.) Mirrors of Mortality: Studies in the Social History of Death. New York: St Martin's Press, pp. 40-60.

Geary, Patrick J. 1994. Living with the Dead in the Middle Ages. London \& New York: Cornell University Press.

Geertz, Clifford 1973. Ritual and Social Change: A Javanese Example. In: The Interpretation of Cultures: Selected Essays. New York: Basic Books, pp. 142-169.

Gordon, Bruce \& Marshall, Peter 2000. Introduction: Placing the Dead in Late Medieval and Early Modern Europe. In: Bruce Gordon and Peter Marshall (eds.) The Place of the Dead: Death and Remembrance in Late Medieval and Early Modern Europe. Cambridge: Cambridge University Press, pp. 1-16.

Gransden, Antonia 1996. Historical Writing in England c. 550 - c. 1307. London: Routledge.

Grimes, Ronald L. 2000. Deeply Into the Bone: Re-Inventing Rites of Passage. Los Angeles: University of California Press.

Grimes, Ronald L. 2006. Performance. In: Jens Kreinath \& Jan Snoek \& Michael Stausberg (eds.) Theorizing Rituals: Issues, Topics, Approaches, Concepts. Boston: Brill, pp. 379-394.

Hertz, Robert 1960. Death and the Right Hand. Transl. by Rodney and Claudia Needham. Aberdeen: The University Press.

Howe, Leo 2000. Risk, Ritual and Performance. The Journal of the Royal Anthropological Institute, Vol. 6, No. 1, pp. 63-79. DOI: 10.1111/1467-9655.t01-1-00004.

Hüsken, Ute 2007. Ritual Dynamics and Ritual Failure. In: Ute Hüsken (ed.) When Rituals Go Wrong: Mistakes, Failure, and the Dynamics of Ritual. Boston: Brill, pp. 337-366. 
Kellehear, Alan 2007. A Social History of Dying. Cambridge: Cambridge University Press. Map, Walter 2002 [1914, available at https//archive.org/stream/waltermapdenugis00mapwuofttpage/ n13/mode/2up]. De Nugis Curialium: Courtiers' Trifles. Edited and translated by M. R. James. Oxford: Clarendon Press.

Maxwell, Herbert (transl.) 2001 [1913, available at https://archive.org/stream/ chronicleoflaner02maxw\#page/n39/mode/2up]. The Chronicle of Lanercost 12721346. Cribyn: Llanerch Press.

Metcalf, Peter \& Huntington, Richard 1991. Celebrations of Death: The Anthropology of Mortuary Ritual, 2nd ed. Cambridge: Cambridge University Press.

Newburgh, William of 1996 [1856]. The History of William of Newburgh (1066-1194). Translated by Joseph Stevenson. Felinfach: Llanerch Publishers.

Oexle, Otto Gerhard 1983. Die Gegenwart Der Toten. In: Herman Braet and Werner Verbeke (eds.) Death in the Middle Ages. Leuven: Leuven University Press, pp. 19-77.

Parker Pearson, Mike 1993. The Powerful Dead: Archaeological Relationships between the Living and the Dead. Cambridge Archaeological Journal, Vol. 3, No. 2, pp. 203229. Available at http://users.clas.ufl.edu/davidson/arch\%20of\%20death/Week\%20 15/Parker\%20Pearson\%201993.pdf, last accessed on September 17, 2015.

Polit, Karin 2007. Social Consequences of Ritual Failure: A Garhwali Case Study. In: Ute Hüsken (ed.) When Rituals Go Wrong: Mistakes, Failure, and the Dynamics of Ritual. Leiden \& Boston: Brill, pp. 199-207.

Reynolds, Andrew 1998. Executions and Hard Anglo-Saxon Justice. British Archaeology, Vol. 31, pp. 8-9. Available at http://www.archaeologyuk.org/ba/ba31/ba31toc.html, last accessed on October 7, 2015.

Schmitt, Jean-Claude 1998. Ghosts in the Middle Ages: The Living and the Dead in Medieval Society. Transl. by Teresa Lavender Fagan. Chicago: University of Chicago Press.

Simpson, Jacqueline 2003. Repentant Soul or Walking Corpse? Debatable Apparitions in Medieval England. Folklore, Vol. 114, No. 3, pp. 389-402. http://dx.doi.org/10 $.1080 / 0015587032000145397$.

Stevenson, Joseph (ed.) 1839. Chronicon de Lanercost M.CC.I.-MCCCXLVI: e codice cottoniano nunc primum typis mandatum. Edinburgh: Bannatyne Club. Available at http://archive.org/details/chronicondelaner00stevuoft, last accessed on October 7, 2015.

Thomas, Keith 1978 [1971]. Religion and the Decline of Magic: Studies in Popular Beliefs in Sixteenth and Seventeenth Century England. London: Penguin Books.

Turner, Victor W. 1967. The Forest of Symbols: Aspects of Ndembu Ritual. Ithaca: Cornell University Press.

Turner, Victor W. 1991 [1969]. The Ritual Process: Structure and Anti-Structure. Ithaca: Cornell University Press.

Van Gennep, Arnold 1909. Les Rites de passage: Étude systématique des rites. Paris: E. Nourry.

Van Gennep, Arnold 1960. The Rites of Passage. Translated by M. B. Vizedom and G. L. Caffee. Chicago: University of Chicago Press.

Watkins, Carl S. 2009 [2007]. History and the Supernatural in Medieval England. Cambridge: Cambridge University Press. 
Elif Boyacıŏ̆lu

Westerhof, Danielle 2008. Death and the Noble Body in Medieval England. Woodbridge: The Boydell Press.

Wieck, Roger S. 1999. The Death Desired: Books of Hours and the Medieval Funeral. In: Edelgard E. DuBruck \& Barbara I. Gusick (eds.) Death and Dying in the Middle Ages. New York: Peter Lang, pp. 431-476. 


\title{
REVIVED SHAMANISM IN THE SOCIAL LIFE OF RUSSIA
}

\author{
Valentina Kharitonova
}

\begin{abstract}
The article reviews various modern practices associated with the concept of revived shamanism. Many of them have an indirect relation to actual shamanism and its revival. However, their adepts can consider themselves followers of traditional shamanism. The author reviews several variants of shamanic activity widely represented in modern Russia, such as: urban shamanism, experiential shamanism, neoshamanism, and also (neo)shamanism or shamanism. They are discussed, taking into account their religious, socio-political, cultural, healing, scientific, ethno-tourist, and economic (business) contexts. The study shows how, depending on various realities of modern life, the activity of specific individuals who identify themselves as shamans, as well as shamanic organisations (legally regarded as religious), changes.
\end{abstract}

Keywords: confession, core shamanism, neoshamanism, religion, revival of shamanism in Russia, shamanism, shamanistic religious organisation, traditional healing, urban shamanism

\section{INTRODUCTION}

When analysing the current state of shamanism in Russia, we have to review quite a wide range of phenomena, which to some extent are included in the complex of what is conventionally referred to as revived shamanism. Many of those phenomena have an indirect relationship particularly to shamanism and its revival. However, their adepts appeal to different traditional variants of shamanism in support of their practices. In this situation the western colleagues would rather use the term 'neoshamanism' - a vague term with many interpretations, allowing researchers and adepts/followers to relate it either to New Age, or to shamanism itself, which has been modernised today (see, e.g., Townsend 2004: 49-56; Winkelman 2004: 187-191).

I see modern versions of shamanic activities (for further details see Kharitonova 2006 and other works by the author) without going beyond the rational interpretation of the phenomenon: the article does not take into account the newspeak creators of shamanic Volkhvy practices, the authors of the new sha- 
manic concepts and texts (see, e.g., Estrin 2006). The materials used are concerned with:

- Urban shamanism (i.e. practices based on indirect knowledge of certain shamanic/ethnic traditions, often the practices of psychologists, combining different variants of healing, including shamanistic; they are widespread mainly in large cities) ${ }^{1}$;

- Experiential shamanism (core shamanism - shamanism by M. Harner, well-rooted in Russia as a result of the work of his disciples, both direct (primarily, A. Slobodova) and indirect (for example, Anzhela Sergeeva). His disciples call this practice basic shamanism);

- Neoshamanism (significantly modernised version of traditional shamanism, which is associated with an indirect reference to the shamanic practices of the successors of traditional shamans);

- (Neo)shamanism or shamanism (reviving the practice of shamans of different traditions directly, through real initiation/training by adepts; yet, these traditions occur with known violations, caused by the modern transformations of the phenomenon as a whole).

The listed variants of shamanic practices have much in common, but they are not entirely similar. And it is clear why: while urban shamanism and experiential shamanism are represented by practices of new 'shamans', who have learned certain techniques (and who, for the most part, are either psychologists or have taken a crash course in psychologies in institutions actively offering the second and third higher education), neoshamanism and (neo)shamanism are represented by those who try to recover their own ethno-cultural traditions, adapting to the contemporary religious and cultural situation in the country, as well as to legislation in the field of health and religious activities.

This is why I refer, if necessary, to different variants of the named shamanisms, reviewing in various contexts the spread and existence of this large-scale phenomenon today. This article engages, quite briefly, some of them: religious, socio-political, cultural, healing, scientific, ethno-tourist, and business contexts. Let us start with the question most important for the renewed practices - about their relations with the religious idea - and consider their religious context. 


\section{HOW SHAMANISM BECAME THE OFFICIAL RELIGION IN THE}

\section{LATE TWENTIETH CENTURY}

The issue of how shamanism is related to religion - originally debatable - gained impetus during the Perestroika period. As it is known, in the early 1990s, three republics - Tuva, Sakha (Yakutia) and Buryatia - included shamanism in the list of traditional religions in their legal documents (for further details see Kharitonova 2006). This action was inscribed in the general context of the 'passions of religion' (stimulated in the country since the 1980s), and national revival. In this context, the term 'shamanism' was used, essentially, for ideological purposes, but it led to a significant transformation of earlier existing practices. Faith is natural for shamans and shamanists; yet, religion with its dogmas and ideological aspirations is excluded from their rich spiritual life: psychology and ideology generate slightly different phenomena. The phenomenon of shamanism, called to life and supported for thousands of years by human psycho-physiology, in the attempts to involve it in ideological programmes of any period of time, turns (a particular part of it) into priestly and religious practices. These practices in fact need for their realisation other professionals who should have somewhat different qualities, characteristics, and abilities than the actual shamans (Kharitonova 2004, 2006; Kharitonova \& Ukraintseva 2007, 2012).

The legalised religious context demanded new ideas from the people who had turned to shamanic practices and joined healing organisations during that period. These ideas appeared in no time in versions borrowed from the wellknown examples of the party and trade union structure (which can also be compared with the administrative system of former kolkhozes); later on they started improving in the direction of copying religious structures. The inclusion of shamanism in the list of official religions necessitated the creation and legal registration of the shamanic organisations that required the availability of some kind of houses of worship, and already existing indoor spaces were easily transformed into them.

Naturally, it did not connect in any way with the traditional shamanic world view and practices of shamanism. However, with time - under the pressure of socio-cultural and religious context - improvement in 'shamanisms' in terms of copying religious ideas and principles gradually became visible. It was not enough anymore to have just a modest shamanic centre / house of worship for the realisation of religious ideas. A plan was devised to build temples or entire temple complexes (e.g. by the Local Religious Organisation of Shamans (LROS) Tengeri in Ulan $\mathrm{Ude}^{2}$, and the Tos Deer and Adyg Eeren in Kyzyl). 
The understanding of their importance and nature of the activities started to transform notably: unusual lexis could be heard in the mouths of shamans: the congregation, prayer, parish, shaman order.

Interestingly, at the same time some of the adepts who considered themselves as (inter alia) shamans, created and revived their 'traditional religions' (the most actively in the regions where Christian Orthodoxy is widespread Yakutia, Khakassia). Here the activity of neoshamans is already moving from a religious to a socio-political context.

\section{SHAMANIC RELIGIOUS ORGANISATIONS AND ELECTIONS OF THE SUPREME SHAMAN}

Certain most active neoshamanic leaders, who had started with the creation of centralised organisations (and without them, as we know, it was impossible, according to the law, to form a confession), later on came up with the idea of uniting the shamans of Siberia, for example. It has not happened yet, but it is quite possible to imagine a union of several national organisations (at least de jure and only on paper). ${ }^{3}$ One of the attempts to centralise was taken by the LROS Tengeri, which organised a regional conference of shamans in April 2011 , but at that time the real unification of all the shamans of Buryatia had not taken place yet. However, the second conference (in April 2013) proved to be more productive, and, as a result, at the end of 2013 the Inter-Regional Centre of Shamans Khaan-Tengeri was established on the basis of this organisation. It should be noted here that a little earlier certain international organisations had appeared, and shamanic leaders were involved in their foundation and operation (e.g. N. Stepanova, who called herself the Supreme Shaman of Buryatia, created the first shamanic organisation in the Republic of Buryatia, and later on organised the Institute of Buryat Shamanism Enherel in Italy (see Romm 2010), while B. Tsyrendorzhiev created a branch of his organisation Tengeri in Berlin). Foreign formations do not affect the activity of the Siberian and, in general, Russian shamanic organisations.

However, in Russia shamans still do not want a comprehensive centralisation, not only because they well remember the Soviet period, with its crosscutting vertical subordination, but because many of them know the traditional canons. This was confirmed as a result of a casus that was provoked by an urban shaman, actively proving himself in the cultural and ethno-tourist fields and working under the pseudonym Elville Olard Dixon. In the spring of 2009, he and his wife (pseudonym Shoncholay Hovenmey) announced on the Internet, and then in the media and on TV, elections of the Supreme Shaman of Rus- 
sia. On a website specifically created for this purpose a long list of candidates for the post was given (by the way, I counted at least six dead people among them). Of course, this was not an adjustment for elections 'in two worlds'; the misunderstanding resulted from a basic ignorance of the situation, since the information about the shamans was taken, among other sources, from someone else's scientific publications. I will not linger on the ethical side and details of this rather comical situation, especially regarding its results, but I would like to emphasise the fact that the rather self-proclaimed election committee was showered with letters from Siberian (neo)shamans who found themselves in the list of candidates for such a high position, and from entire shamanic organisations demanding to remove their names from the electoral list as they did not know at all about this action and had not given their consent to participate in it. The basic requirement, of course, was to stop the action itself. Serious (neo)shamans and leaders of shamanic associations, such as Ai-Churek S. Oiun and B. Rinchinov, spoke out against such a policy for many reasons, including the fact that they did not want to build a vertical structure with a focus on the capital.

Obviously, the politicisation of the shamanic revival in the form of shamanism, embedded in a religious-political framework and structures, did not correspond to the ideas of the Siberian adepts about shamanism. Assuming that neoshamanic practices significantly changed their functioning in comparison with traditional shamanism, (neo)shamans were not ready to create a religious and administrative structure on the country level. On the local level, on the other hand, many of them are not only members of the LROS, thereby forming a grassroots religious unit, but also participate in the political life - for example, in the election campaigns. However, they try not to get involved in various political actions, especially on the side of the protesters. For example, Buryatian youth protests against the inclusion of the Ust-Ordynsky Buryat Autonomous Region and the Aginsky Buryat Autonomous Region in bigger administrative entities were not supported by shamanic organisations, although in words many neoshamans were in agreement with the ideas of the young. At the same time some of the local neoshamans in several regions, having been invited to official ceremonies to support the governmental position, participated in them. They are also engaged in consulting officials on various issues:

Having arrived at the house of the old man Danilo (Sushkenov - V. Kh.), we noticed at the gate two black Volgas with blue licence plates; it turned out that the shaman was consulting the employees of the Department of the Interior Affairs. (Ketkovich 2004)

Sometimes even officials of the 'first circle' become parentalised by them. 
Spiritual and cultural components, naturally, became more important for modern shamanism. National revival, as well as the prevailing cultural context, helped to actualise these sides of traditional shamanhood and shamanism (on the distinction of the terms see Kharitonova 2004, 2006; Funk \& Kharitonova 2012 [1999]) already in the period of perestroika in the country.

\section{SHAMANISM AND CULTURAL REVIVAL}

The national-cultural revival during the perestroika period aspired to find distinctive, special components in the culture of ethnic groups interested in the revival. It was shamanism, which was transformed and almost eradicated during the Soviet period and the remains of which could still be found in Siberia, that met the requirements (about the peculiarities of the transformation of shamanism in the USSR see Kharitonova 2010). However, shamanism itself with its personality cult and specific features that allowed to predict, diagnose, and heal - intensified in line with the development of traditional healing. And in the process of cultural revival priestly practices were put at the forefront, easily updated by the well-preserved domestic shamanhood (on the preservation of traditions see, e.g., Funk 1997; Pimenova 2007). At the same time a folklore component of shamanism came to the fore, creating curious processes. Below I will dwell upon a few important and interesting issues.

The first one is the inclusion of shamanic elements in revived folk festivals (created according to scenarios, written, inter alia, by using ethnographic and folklore literature), some of which have become legitimised in their republics (for example, Ysyakh in the Republic of Sakha since 1991, Chyl-Pazy in Khakassia since 1995, Alhalalalay in the settlement of Kovran since 1987, and officially in the Kamchatka region since 2010 (http:/www.sgan2009.ru/Prasdniki/Alxalalay/ Alxalalay.html)), whereas others exist in more modest local variants.

The second issue is the very frequent occurrence of actors in the role of shamans on the professional stage and in films, and (neo)shamans on the stage and screen as shaman-healers and soothsayers. Unfortunately, sometimes they show a complete ignorance about the traditions and actively violate them.

The third topic of interest is the folklorisation of phenomena along with their desacralisation; for example, in the case of performing shamanic folklore by the shamans' descendants of the Kosterkin clan (see Dobzhanskaya 2013: 75-85). The transfer of the elements of shamanic practice onto the professional scene and, especially, into the sphere of amateur performance, is not a new phenomenon; such attempts existed already in the Soviet period. However, the general context of what is happening is rather interesting: people who consider 
themselves modern shamans or direct descendants of shamans appear on the stage and in the sphere of amateur art. None of them is forced to do it under the pressure of propaganda of atheism; conversely, there is an active and explicit policy of religionisation in the country.

What is it: the legacy of atheistic education of the past or rather the victory of the world religions, particularly Protestantism, actively spreading in the northern and Siberian regions and changing attitudes towards traditions? Perhaps this is the result of living in the country that has chosen the path of atheism for several decades, which allowed the desacralisation in their minds of both the image of a shaman and the phenomenon of shamanism as a whole?

In any case, the main component of shamanism remains the most important for the direct and indirect followers of shamans: its soothsaying (clairvoyant) and healing origin of shamanism, the revival and modernisation of which has been actively built into the healing context since the 1980s.

\section{TRANSFORMATION OF SHAMANISM AND TRADITIONAL HEALING}

A major component of the modern variants of shamanism is the practice of spiritual healing, coupled with soothsaying / fortune-telling, as well as with the elements of folk healing on the one hand and professional psychotherapy on the other. This is predetermined by the orientation of traditional shamanism to restore the spiritual and psycho-physiological integrity of the members of a society, those patronised by a shaman. The revival of shamanism, we can say, is in perfect harmony with the process of the emergence of traditional healing, which began in the 1980s. Let us leave aside the question of the development level of Soviet medicine and the collapse of the health care system in the era of perestroika, which are often used to explain the appearance of traditional healing as a profession and actualisation of shamanic healing practices. Let us direct our attention to other processes, those closer to shamanism.

The revival of interest in the healing component of spiritual culture and the healing practices developed in parallel to the emergence of traditional healing - a phenomenon representing, in the post-Soviet space, an analogue of traditional medicine, which was forming in the later versions in the twentieth century in some regions (or countries) as either publicly (China) or privately (e.g. Korea) defined systems based on ethnic magical-medical practice. The Russian Federation partly follows the way of China: of course, the Russian system of traditional healing was not formed by a directive of the leader of the country (cf. China: Lynteris 2012), but with the active cooperation by a number of in- 
terested individuals from medical science and scientific areas related to it. The process evolved, on the one hand, as a spontaneous revival of ethno-medicine (and magical-medical as well as magical-mystical practices), and, on the other hand, as regulated from above by a scientific community of primarily medical and psychological orientation.

Shamanism, based on psychotherapy and spiritual practices, as well as on healing activity, was also drawn into it. In fact, many neoshamans came to the practice indirectly: they studied with various healers, hypnotists, and parapsychologists; some took special courses at the schools of healers. Naturally, further on neoshamans and traditional healers developed, for the most part, in parallel: some neoshamans as well as practicing healers received diplomas of healers, passed a range of certifications, became members of academies, were issued credentials similar to state certificates, indicating the existence of a scientific degree of a Candidate or Doctor of Science (including in the field of psychology). Even after groups of neoshamans, having been united in a modern way, legally established their centres in the manner of the LROS, they still continued to be engaged in spiritual and practical healing, ${ }^{4}$ except that, as a result of administrative checks of their work, they removed price lists for their services from the walls (see, e.g., Kharitonova 2008). It should be mentioned here that there are usually no indications of healing activity in the rules of the LROS (to practice it, beginning in 1993, one needs to have documents about special education and licenses).

Thus, de jure, healing practice in religious organisations turns out to be illegal. De facto it continues to exist, but is not advertised; however, the local population knows what traditional shamans, healers, and doctors have always done and actively ask neoshamans for help.

Since 2012, the situation with spiritual healing has become much simpler: according to the new Law on Health Care (in fact, effective from 1 January 2012), this activity is unrelated to medicine and does not require licensing. The healing services offered by shamans of various kinds are not tracked and hence are not prohibited (as, in fact, is the entire ethnic medicine). Variants of psycho-correction, offered in conjunction with shamanic techniques, also lie on the conscience of psychologists/shamans; typically, such professionals are certified for some areas of psychology and psychotherapy, but that does not mean that they work within the framework of only those practices for which they are certified.

As the demand for shamanic services is currently considerable not only in traditional shamanic regions, but also among certain parts of the population of the world, even foreign clients turn to specialist of revived shamanism for professional help. They come to Russia as a variant of specific scientific tourism 
or ethno-tourism; experts themselves travel to different countries of the world, where they give their training seminars (see http://www.shamanstvo.ru/news_ shaman/2005/news-37.htm) with shamanic healing sessions, and some of them organise permanent working centres (e.g., as already indicated, N. Stepanova in Italy and France, etc.); clients and shamans-healers meet at scientific conferences, and rather often at events of pseudo-scientific nature.

In fact, healing practices nowadays do not even require certification; however, the desire to get some certificates from representatives of revived shamanism is rather obvious: sometimes not only psychologists / urban shamans, but also neoshamans seek different ways to be engaged in the context of science.

\section{BETWEEN TRADITIONAL RELIGION AND MASS SCIENCE}

Today this situation requires a special detailed analysis (which, unfortunately, cannot be given in a small review article).

For now we can say that at the present time (largely thanks to the Internet) something has formed in the field under discussion that, by analogy with mass culture, should be called mass science. The integration of scientific thought and metaphysical concepts, as well as of the theories based on 'contactee insights' activated as far back as in the 1980s. A magnificent illustration of this were numerous events such as conferences and congresses where, for example, traditional healing was discussed, as well as new psychological areas and even more unusual phenomena explored at that time.

A distinguishing feature of such events is their interdisciplinarity. When representatives of various scientific domains of knowledge assemble, and, moreover, with practising 'discoverers of the truth' through a variety of virtual characters (from traditional spirits, deities, and gods to cosmic teachers and aliens), the basic idea of interdisciplinarity is implemented pretty quickly: those seeking for the truth find themselves between disciplines, as well as between science and 'divine revelation', being convinced that they have managed to integrate both these crafts. In many cases, this makes some people believe that they have gained access to revelations that science is still not able to explain, while someone has already 'felt' it and brings a new truth to the world; others, at the same time, arrive at the conclusion that it is them who help science 'scientifically', and interpret the unknown on another, higher level.

Today mass science, as well as mass culture, is an inevitable and inescapable phenomenon - the Internet and the mass media contribute to it actively. It is impossible to get rid of it, but the situation must be rectified: firstly, for the scientists who identify interdisciplinary methods of research with complex 
research of specific phenomena (of which their personal knowledge is often insufficient to interpret the subject through basic knowledge and methods of other sciences, in which they are not experts), not to mislead colleagues and not to contribute to the transformation of science into mass science, and secondly, for spiritual practices (including traditional) to remain spiritual practices and do their (rather important) business and not to offer scientific theories.

All this is relevant to neoshamanism and experiential shamanism and especially urban shamanism. It is no secret that many modern shamans of various kinds are people with high educational status. However, every particular person has his/her own thoughts about the relationship between science and shamanic practices. In general, we could say that some of them, due to their education and activities, including scientific, went into shamanism, while for others, on the contrary, science was needed when they felt the shaman's call, in order to understand what was happening to them - to clarify the scientific bases of shamanic practices and conditions.

However, unfortunately, some of the current shamans have not refused the possibility of a simple acquisition of certificates of different types: it is about inclusion in the domain of academic degrees and titles through commercial organisations offering diplomas and certificates, including master's and doctor's degrees, in the field of psychology and of different specialisations in the field of medicine, as well as membership in academies. Behind all this lies a serious problem of faking: either intentional (with commercial and other purposes in mind) or unintentional (delusion because of ignorance, self-deception because of the individual features of the psyche, etc.); sometimes both these factors elegantly combine.

Unfortunately, this leads to necessitated scientific fraud. Sometimes there are references to the works of 'well-known shamanologists' who actually do not even have secondary education, in scientific publications, including dissertations. However, some researchers mistake foreign aliases of current publishers for original names and include them in the list of references. On the other hand, people who in fact have just read ethnographic or esoteric literature offer healing services and call themselves shamans initiated by the Great Spirit.

There is certainly also a positive inception in the introduction of the phenomenon of mass science (one might say, in its revival, as well as that of shamanism: it is not the first time for the humanity to step on the same rake). We might hope that the current situation will make serious researchers study, more actively, well-founded psycho-physiological and neuro-psychic subtexts of shamanism and other such phenomena; yet for now, unfortunately, enthusiasts or shamans themselves are engaged in it to a larger extent. However, the latter often prefer other spheres of operation, for example, ethno-tourism. 


\section{TRAVELLING AROUND THE PLACES OF POWER}

'Shamanisms' appeared rather quickly in this sphere (if we understand the term ethno-tourism in its extended version). Initially, the focus was on individual trips of invited (neo)shamans to large Russian cities (especially to Moscow), the neighbouring countries, and to countries further abroad. They travelled to participate in various events (conferences, including scientific and business forums with a 'scientific' component), to organise so-called educational seminars (where they taught the basics of Shamanism) as well as rituals (see, e.g., Oiun 2011). ${ }^{5}$ Naturally, in return, non-resident and foreign fans of olden times flocked to the depth of the country to get acquainted with the local way of life of shamanists and shamans. And if they experienced some disappointment with regard to shamanists - they did not really seem to like the expected 'religionists' and were sometimes even not interested in these olden times - in just 3-5 years tens and hundreds of 'shamans' appeared out of nowhere, satisfying all their queries. This was true especially in terms of teaching them shamanic techniques: in the 1990s the new shamans still tried to make a secret of their knowledge, and in the twenty-first century, suddenly it became clear that there was nothing to hide (quantity destroyed quality) and they began active trainings and initiations right on the premises. Simultaneously, various books containing revelations about the techniques of shamanism started appearing rather actively in mass science (see, e.g., Sarangerel 2003; Fedorov 2005).

In the $2000 \mathrm{~s}$, new variants of ethno-tourism emerged. Some neoshamans got their own sites on the Internet and began to develop their ethnic and cultural activity in their small motherland and in different 'sacred' places in the world. Today various groups from Russian cities and foreign countries travel to Siberia to participate in the rituals (including calendar holidays), for the sake of visiting holy places (places of power) and study shamanic craft. All this takes place in shamans' organisations or other venues where cultural and entertainment events are held. There are so-called ethno villages and art houses where, as also in the LROS, such actions are carried out. Even more actively than before, neoshamans visit various events in the capital, while the range of the organisers of such events has expanded and somewhat altered. At specialised exhibitions, seminars, and ceremonies in the capital and other cities, representatives of Russian and foreign shamanism of various kinds can be found. They share their experience and knowledge, and it does not bother anyone, because the globalisation and universalisation of the 'shamanic knowledge' and mental experience have been observed already for a long time. Against this background ethno-tours to Morocco and Nepal, organised by neoshamans 
to visit 'places of power', and inclusion into the shamanic practice do not look so strange anymore (see, e.g., www.kobezhikova.ru/travel.shtml).

Another interesting line that does not particularly stand out from the general stream of shamanic movements is travelling to the North and Siberia in the homeland and visits to the Americas and other continents in search of doping variants of shamanism with Amanita muscaria (fly agaric), ayahuasca (entheogenic brew made out of Banisteriopsis caapi vine, often in combination with various other plants), peyote, etc. (cf. Dobkin de Rios \& Rumrrill 2008). Back in the 1990s, for example, a secret import of raw materials for the producing of ayahuasca began, particularly in Moscow. Interest in it, as well as in peyote, was caused by the stories of Carlos Castaneda and the book, The Way of the Shaman, by M. Harner, as well as the mention of the use of ayahuasca in various scientific publications. Knowledge of Amanita muscaria and other mushrooms stimulated shamanic tours on the Siberian grounds. However, all this has much more to do with urban shamans, rather than with (neo)shamans.

In places where people showed an interest in teaching practices, in exploring the unknown in faraway places, and in rare raw material used to immerse into special states of consciousness, a specific shamanistic business context was formed.

\section{SHAMAN IN THE CONTEXT OF CONTEMPORARY CAPITALISM}

Obviously, in the modern world based on financial calculations, everything mentioned in relation to the development of shamanic activities could not, and should not have been done gratuitously. If we consider that the processes of the revival of shamanism took place in parallel with the redistribution of capital and the spread of capitalism in the country, it would be strange to expect the revival of traditional practices of shamans and healers in the form of bartering. We can compare, for example, how the practice of Reiki in Japan, in the period of the spread of capitalism in the country, was restored, enriched by the idea of 'money equals energy', i.e. according to energy exchange, one should pay in cash for the energy spent by a healer (see Kharitonova 1997: 24); so the idea about the price for a service which had to be paid became natural. The help offered in shamanistic healing centres, i.e. within the LROS, became fee-based. Another aspect is that the 'clergy' found themselves in a difficult situation: because of their status, they do not have the right to trade their services. Naturally, they had to turn to the practice of donations. 
More natural was the approval of the financial side when seminars, workshops, and even shamanic initiations were organised, because there existed appropriate models adopted in the field of education, actively developed in the country during the same period, in the field of teaching psychology and psychotherapy. The western experiential shamanism, which began to penetrate into the territory of the USSR already in the late 1980s, was another, more familiar model.

Thus, the revival of shamanism was initially put on a commercial footing, which was provoked by the socio-economic status of the new shamans - they had to make a living and acquiring the status of a shaman or a healer provided, albeit sometimes modest, earnings. In the period of instability (which saw many people surviving almost without a salary), many viewed this as a way out of a difficult situation, but at the same time most of them went through serious depression and even psychosomatic diseases, which was perceived by many as a shamanic illness. During this period, the idea of a shamanic illness dramatically transformed (or rather, most of the latter-day shamans did not know what the specifics of this state were, because it was often associated with just troubles and misfortunes that befell them (see, e.g., Pimenova 2007).

Practice in one's own region is not always good enough to provide for a decent livelihood for new shamans, so a large number of them move to big cities or the capital, whence it appears easier to go, even for quite long periods, to work in the West. Thus, some of the well-known contemporary practitioners work either in their native regions, or in the capital and other major cities in Russia, or outside the country. Usually fixed, periodically working centres are established: for example, an Altai neoshaman can practice at home, from time to time travel to Salekhard and Moscow, and sometimes also work in Turkey, etc. For some experts Moscow has become their second hometown, where they continuously live, sometimes paying brief visits to their homeland for 'energy supply'. The practice of leaving the place of permanent residence for short-term visits to European countries or Turkey still persists. But attempts are also made to establish regular contacts, with the creation of branches of the LROS in European countries (in Germany, for example), and permanent centres in Italy and France, which was already mentioned above. 


\section{INSTEAD OF CONCLUSION}

Obviously, the revived shamanism is forced to adapt to modern conditions, and transforms according to Soviet and post-Soviet mentality of the authors of its revival and its modern adepts. It would be logical to assume that the process of modernisation is not going to stop. At this stage, in addition to the development of the individual practices in various forms (including the option of combining neoshamanic activities with work in network structures), attempts are being made to consolidate shamanic organisations. However, this has not been accomplished by today, and the established organisations have been disbanded or reformed. In Buryatia in April 2013, the second conference of consolidating shamans, initiated by LROS Tengeri, was held and the same organisation began to build a shamanic temple in Ulan-Ude in September 2013 and re-registered it as the Inter-Regional Centre of Shamans Khaan Tengeri. ${ }^{6}$ However, the ambition of individual leaders to form in Russia a shamanic confession under the current polyvariety of 'shamanisms' is unlikely to succeed, unless they are urged by some new legislative initiatives and social transformations. ${ }^{7}$

\section{NOTES}

1 Some modern scholars sometimes use this term to refer to the practices of neoshamans and (neo)shamans who settle in towns and villages (see, e.g., Shaglanova 2007). I do not see the point in it, as the mentioned transformations (the organisation called Local Religious Organisation of Shamans (LROSH), etc.) are not related to changing rural environment into urban, but to the administration of religious and cultural processes; (neo)shamans-individualists still have their practice in cities, towns, and rural settlements, while the inhabitants in the countryside are regularly involved in the work of urban and community LROSH sections. The organisation is represented in all the republics that legally recognise shamanism as one of the traditional religions.

2 The LROSH Tengeri is currently building a large temple on the territory designated by the organisation; moreover (according to the personal message of the head of the organisation, B. Tsyrendorzhiev), the shamans of this organisation have revived the basics of religious doctrines and the main precepts of shamanism. Interestingly, the shamans attempt to correct traditional ideas about the practice of shamanism, in particular, B. Tsyrendorzhiev has said in one of his interviews: "Today, many ethnographers are wondering how shamans can build their temples, but I think it happened earlier as well, but has been forgotten by now. In the time of Genghis Khan shamanistic temples existed; this can be concluded on the basis of The Secret History of the Mongols. So, the shaman of Genghis Khan, Tengeri, had his house-temple, where he performed rituals, worshipping the eternal blue sky. Because of globalisation, we are departing from traditions, while in other countries people still remember their religious culture. There are shamanistic temples in South Korea, and Shinto temples in Japan, while there are only projects in Mongolia and Russia, but still no temple. And I think now it is the time to build a shamanic temple" (Tsydenova 2013). 
3 Attempts of such consolidation occur in different republics: in Tuva, for example, several organisations are subordinated to M. Kenin-Lopsan and constitute a kind of centralised system; a slightly different variant can be found in the Irkutsk region - the Council of Shamanic Communities of the Baikal Region (see http://www.bur-culture. ru/index.php?id=55).

4 Information about this is not always accurate, and is sometimes unreal, and has appeared in various publications, even before it hit the papers of the Government Commission of the Republic of Tyva (see Kharitonova 2008). For example: "In the waiting room, on the secretarial desk, there was a price list, in which services and their prices were listed in the Tuvan language. Thus, purging a house cost 100 thousand roubles, and with a visit to the kozhuun (administrative district) - 150 thousand roubles (July 1997). The list of services also included the treatment of various diseases and the traditional Tuvan fortunetelling huvaanak. The visitor explains the essence of the problem to the secretary, pays the cashier, takes the receipt and goes to a shaman or a soothsayer. The shaman receives a certain percentage of the fee, the rest goes to the fund of the society" (Myshliavtsev 2009).

5 "In 2004, after a visit to Tuva, Siegfried, the leader of the shamans in Germany, invited me, shamaness of the society Spirit of the Bear, to Bielefeld, Germany, for experience exchange. There I held my first seminar on Tuvan shamanism" (Oiun 2011).

6 The head of a new centralised organisation, B. Tsyrendorzhiev, has big plans, which he willingly shares with reporters: "Currently we are establishing the Institute of Shamanism. In the spring of this year a large conference on the current state of shamanism was held. Shamans and the scientists of the Irkutsk region from the Trans-Baikal Territory attended it. We then adopted a resolution on the unification of shamans. And now we are applying for the establishment of inter-regional centralised religious organisation of shamans, Khaan Tengeri. The organisation will unite not only the shamans living in ethnic Buryatia, but also the ones from other regions of Russia. The shamans of the Omsk region, the Moscow region, and the city of Astrakhan have already applied for membership in this organisation. We are also creating a structure for managing the organisation. So, in that way the supreme shaman will be elected, as well as an assembly called duherig (circle in Buryat). This assembly would include the heads of regional organisations of shamans" (Tsydenova 2013).

7 For example, changes in the Law on Health Care: in the last law of 2012 (Art. 50, Traditional Medicine) shamanic healing is not regulated. However, at present (2015), bylaws are being prepared, according to which the healing practices of not only shamans, but also of other specialists will be largely restricted. 


\section{REFERENCES}

Dobkin de Rios, Marlene \& Rumrrill, Roger 2008. A Hallucinogenic Tea, Laced with Controversy: Ayahuasca in the Amazon and the United States. Westport: Praeger Publishers.

Dobzhanskaia, Oksana 2013. Nganasanskie obriadovye pesni v ispolnenii naslednikov shamana Demnime: K probleme imitatsii shamanskogo rituala. [Nganasans' Ritual Songs Performed by the Successors of the Shaman Demnime: On the Problem of Ritual Imitation.] In: V. Kharitonova (ed.) Epicheskoe nasledie i dukhounye praktiki $v$ proshlom $i$ nastoiashchem. Etnologicheskie issledovaniia po shamanstvu i inym traditsionnym verovaniiam i praktikam. T. 15, ch. 1. Moskva: IEA RAN, pp. 75-85.

Estrin, Anatolii 2006. 100 shamanskikh zagovorov: Praktika Vizardiki. [100 Shamanistic Spells: Practice of Vizardika.] Sankt Peterburg: Krylov.

Fedorov, Vladimir 2005. Tainy vudu i shamanizma: Vo vlasti potustoronnikh sil. [Secrets of Voodoo and Shamanism: In the Power of Supernatural Forces.] Moskva: Veche.

Funk, Dmitrii 1997. Teleutskoe shamanstvo: traditsionnye etnograficheskie interpretatsii i novye issledovatel'skie vozmozhnosti. [Teleut Shamanhood: Traditional Ethnographic Interpretations and New Research Opportunities.] Moskva: IEA RAN.

Funk, Dmitrii \& Kharitonova, Valentina 2012 [1999]. Shamanstvo ili shamanism? [Shamanhood or Shamanism?] In: "Izbranniki dukhov"- "Izbravshie dukhov": Traditsionnoe shamanstvo i neoshamanizm. Pamiati V.N. Basilova (1937-1998). ["Chosen by Spirits" - "Chosen Spirits": Traditional Shamanhood and Neoshamanism. In Memory of V.N. Basilov (1937-1998).] Etnologicheskie issledovaniia po shamanstvu i inym traditsionnym verovaniiam i praktikam, T.17. Moskva: IEA RAN, pp. 109-137. Available at http://static.iea.ras.ru/books/Kharitonova_17_Tom.pdf, last accessed on October 21, 2015.

Ketkovich, Vlad 2004. Sovremennyi buriatskii shamanism. [Modern Buryat Shamanism.] Geografiia, No. 28. Available at http:/geo.1september.ru/view_article.php?id=200402809, last accessed on October 21, 2015.

Kharitonova, Valentina 1997. Tselitel'stvo i metodika Reiki. [Healing and Reiki Technique.] VITA: Traditsii. Meditsina. Zdorov'e, No. 2, pp. 23-25.

Kharitonova, Valentina 2004. Shamany i shamanisty: nekotorye teoreticheskie aspekty izucheniia shamanizma i inykh traditsionnykh verovanii i praktik. [Shamans and Shamanists: Some Theoretical Aspects of the Study of Shamanism and Other Traditional Beliefs and Practices.] Etnograficheskoe obozrenie, No. 2, pp. 99-118. Available at http://journal.iea.ras.ru/archive/2000s/2004/2.htm, last accessed on October 21, 2015.

Kharitonova, Valentina. 2006. Feniks iz pepla? Sibirskii shamanizm na rubezhe tysiacheletii. [Phoenix from the Ashes? Siberian Shamanism at the Turn of Millennium.] Moskva: Nauka. Available at http://static.iea.ras.ru/books/Phoenix.pdf, last accessed on October 21, 2015.

Kharitonova, Valentina 2008. Sovremennaia religioznaia situatsiia v Respublike Tyva. [Modern Religious Situation in the Republic of Tyva.] In: D. Funk (ed.) Tiurkskie narody Vostochnoi Sibiri. [Turkic Peoples of Eastern Siberia.] Moskva: Nauka, pp. 166-184. 
Kharitonova, Valentina 2010. Politika, korrektiruiushchaia traditsii: (neo)shamany i (neo)shamanizm v SSSR i RF (1922-2010 gg.). [Politics Correcting Traditions: (Neo)shamans and (Neo)shamanism in the USSR and the Russian Federation (1922-2010).] In: František Bahenský a kolektiv. Národnostní politika na teritoriu bývaleho SSSR. Praha: Etnologický ústav Akademie věd České Republiky, pp. 85-120.

Kharitonova, Valentina \& Ukraintseva, Iuliia 2007. Zov bezmolviia, ili pochemu oni shamany? [Call of Silence, or Why Are They Shamans?] Races and Nations, Vol. 33. Moskva: Nauka, pp. 218-245.

Kharitonova, Valentina \& Ukraintseva, Yulia 2012. Destined for Shamanic Inspiration: An Integrative Study of Buryat (Neo)Shamans. In: D. Eigner (ed.) Consciousness: Cultural and Therapeutic Perspectives. Frankfurt am Main \& Berlin \& Bern \& Bruxelles \& New York \& Oxford \& Wien: Peter Lang International Academic Publishers, pp. 109-130.

Lynteris, Christos 2012. The Spirit of Selflessness in Maoist China: Socialist Medicine and the New Man. Basingstoke \& New York: Palgrave Pivot.

Myshliavtsev, Boris 2009. Normativnaia kul'tura tuvintsev (konets 20 - nachalo 21 veka). [Regulatory Tuvan Culture (Late 20th - Early 21st Century).] Available at http:// samlib.ru/m/myshljawcew_boris_aleksandrowich/tuva-1.shtml, last accessed on October 21, 2015.

Oiun, Liudmila 2011. Podruzhilsia s tuvinskimi shamanami. [Becoming Friends with Tuvan Shamans.] Tuvinskaya pravda. Obschestvenno-politicheskaya gazeta, No. 64, June 23. Available at http://www.tuva.asia/news/tuva/3566-shamany. html, last accessed on November 4, 2015.

Pimenova, Kseniia 2007. Vozrozhdenie i transformatsii traditsionnykh verovanii i praktik tuvintsev $v$ postsovetskii period: osnovnye problemy. [The Revival and Transformation of Traditional Beliefs and Practices of Tuvinians in Post-Soviet Tuva: Main Problems.] Dissertation for the degree of Candidate of Historical Sciences. Moskva: IEA RAN. Available at http://dlib.rsl.ru/viewer/01003052651\#?page=1, last accessed on November 10, 2015.

Romm, Valerii 2010. Interv'iu s Verkhovnoi shamankoi Buriatii Stepanovoi Nadezhdoi Anan'eunoi. [Interview with the Supreme Shaman of Buryatia, Nadezhda Stepanova.] Available at http://slavzso.narod.ru/s-d/10/S3.html, last accessed on October 21, 2015.

Sarangerel 2003. Zov shamana: Drevnie traditsii i dukhounye praktiki. [Call of the Shaman: Ancient Traditions and Spiritual Practices.] Moskva: Fair-press.

Shaglanova, Olga 2007. Shamanizm u buriat Tunkinskoi doliny (Vtoraia polovina XIX$X X v v$.). [Buryat Shamanism in Tunka Valley (second half of the 19th and the 20th cc.).] Dissertation for the degree of Candidate of Historical Sciences. Ulan-Ude. Available at http://dlib.rsl.ru/01002618387, last accessed on November 10, 2015.

Townsend, Joan B. 2004. Core Shamanism and Neo-Shamanism. Shamanism. In: Marico Namba Walter \& Eva Jane Neumann Fridman (eds.) Shamanism: An Encyclopedia of World Beliefs, Practices, and Culture, Volume 1. Santa Barbara, California \& Denver, Colorado \& Oxford, England: ABC-CLIO, pp. 49-56. 
Tsydenova, Ariuna 2013. Shamanskii khram v Buriatii. [Shaman Temple in Buryatia. Interview with B. Tsyrendorzhiev.] Baikal 24: Informatsionnyi portal. September 17. Available at http://www.baikal24.ru/page.php?action=showItem \&type $=$ article\&id=14136, last accessed on October 21, 2015.

Winkelman, Michael 2004. Neuropsychology of Shamanism. In: Marico Namba Walter \& Eva Jane Neumann Fridman (eds.) Shamanism: An Encyclopedia of World Beliefs, Practices, and Culture, Volume 1. Santa Barbara, California \& Denver, Colorado \& Oxford, England: ABC-CLIO, pp. 187-196. 


\title{
THE ROLE OF FOLKLORE IN THE FORMATION OF LATVIAN VISUAL ART
}

\author{
Toms Kencis
}

\begin{abstract}
Latvian folklore, folk ornament, and mythology were an established symbolic capital upon which the second generation of ethnic Latvian artists built a national particularity of visual art during the fin de siècle decades. The construction of national art represents artistic and discursive processes of exchange and conflict between the imperial centre and the local periphery, the Baltic German elite and ethnic Latvian artists, international styles and local particularities. The idea of national art developed within the framework of free discussion, borrowing models of identity from more mature art scenes abroad as well as from other areas of cultural representation, like folklore and ethnography. As a result, several coexisting versions of national art identity are distinguished in the given period. Visual arts were 'nationalised' through form - developing particular ethnographic patterns of ornamentation - or through content, the latter ranging from local landscapes and people to motifs of ancient history, folklore, and mythology. Although developments in visual arts follow the international pattern, the application of conclusions emerging from a wider field of studies on cultural nationalism shows that folklore has played a special role due to the particular setting of cultural production in Latvia.
\end{abstract}

Keywords: art criticism, Finland, folklore, Latvia, mythology, nationalism, visual arts

\section{INTRODUCTION}

Artworks are declared to be a part of national heritage, particular artists are proclaimed to be national artists, and certain works are included in the national canon of art. These processes are retrospective and related to both the professional and the public perception of art history. However, before them lie discursive fields of present/past: the creation of artworks is always embedded in particular socio-political environments, discussed within critical stances, supported or hindered by institutional, academic, and bureaucratic apparatuses. Being a part of them, each artwork creates, challenges, and comments on the aesthetic dispositions of its time. Each artwork is a mute record of the artist's voice, related to his or her personality, part of his or her oeuvre. The 
long nineteenth century gave birth to modern nationalism and the first wave of nation-states that appeared on the stage of history. The second wave followed the collapse of empires after the Great War and the Russian revolution. The result was the emergence of multiple, relatively small, ethnocentric new states in Northern, Eastern and Central Europe, for example, Finland (1917), Poland, Hungary, Czechoslovakia, Estonia, and Latvia (1918), the latter being examined in detail below. The political act of declaring independence was preceded by decades of social change and the ideological formation of so-called national awakenings, partially taking shape also in the realm of cultural production or, as Miroslav Hroch (1985) has titled it, the phase of cultural nationalism. The case of Latvia at the turn of the century provides rich material for mapping various nationalising strategies of symbolic heritage making, the piratisation (cf. Anderson 2006 [1983]) of models of nationalism, the adaptation of international art styles and genres, and discursive practices manoeuvring between multiple identity models. While both the role of folklore in constructing Latvian national identity and recently also Latvian art history around the turn of the century have been studied quite extensively, the aim of this article is to bring together knowledge from both fields. Such an approach would allow us to capture the mechanics of transfer of certain imagery from popular to elite intellectual systems, establishing also a basis for studying the reflexive relationship between both systems.

\section{THE CONDITIONS OF ARTISTIC PRODUCTION}

Contemporary Latvia, once located at the western edge of the Russian Empire, was comprised of part of Die deutschen Ostseeprovinzen Russlands (the German Baltic Provinces of Russia), which were mainly protestant countries and held some of the industrially most advanced cities in the empire, and part of the Province (guberniya) of Vitebsk. It was a German cultural area with Baltic German and German-speaking elites, mainly populated by ethnic Latvians ${ }^{1}$ and ruled by Russian imperial laws within the geopolitical framework of the empire. For the emerging Latvian nationalism this situation provided a set of choices. The more conservative circles of the 1870s aligned with Baltic German proLatvian, relatively liberal Lettisch-Literärische Gesellschaft or Latviešu Draugu biedrība, ${ }^{2}$ while others proclaimed allegiance to Russian central governmental bodies, gaining a foothold against local Baltic-German elites. The turn of the century saw the introduction of the influential social-democratic revolutionary generation of $1905 .{ }^{3}$ The Latvian national movement was definitely not consolidated at the end of the century, nor was the vision of national culture. 
Despite historiographical efforts to background multinational connections in the studies into art history carried out during the period of national independence as well as under the Soviet occupation, the local art scene "was mainly determined by the coexistence of German and Latvian cultural powers, ranging from mutual forthcoming and stimulating rivalry to politicised confrontation" (Ābele 2006: 39). A more mundane but nevertheless influential factor was the art market: the most profitable was the genre of the representational portrait (Kḷaviňs 1996), and artists as well as critics regularly complained that local audiences were not inclined to invest in artworks at all (e.g. Ābele 2006: 42). Regardless of the artists' nationality, the majority of buyers purchasing local artworks were of Baltic German origins. However, the artworks were sold also in other regions of the empire and in Western Europe.

The circles of people who supported artists in different ways beyond the commercial relationships between buyer and seller were also heterogeneous with regard to ethnicity, social standing, profession and the reasons for philanthropic actions. Here one can detect the emerging traits of private patronage and similar forms of promoting art. (Ābele 2014: 103)

The rhetorical demand for ethnically particular Latvian art, articulated by artists themselves and public intellectuals, exceeded the real demand. While closer to the end of the period works of Latvian artists were both produced and bought more, the situation changed considerably only after the First World War, when Latvian state institutions for preserving and promoting art were established.

Career opportunities of nationally minded new artists were limited, to some extent, by the lack of exhibition prospects in their native country. The Riga City Art Gallery was established in 1868, and three years later it joined up with Kunstverein zu Riga (the Baltic German Riga Art Society), which was founded in the same year, 1872, with the aim of popularising visual arts and promoting art in the Baltic Provinces as well as holding exhibitions and compiling a collection of outstanding artworks. The successful cooperation between the two leading agencies of artistic life in the capital city Riga led to the building and establishing of the City Art Museum in 1905. The new building was shared with the Kunstverein. The museum collection consisted mainly of works by Baltic German and Western European artists. The museum held about 60 exhibitions before 1918, only four of which were solo shows by ethnic Latvian artists. Requests for the use of the premises for joint exhibitions by Latvian artists were rejected, sometimes leading to open conflicts and complaints filed by the Latvian Art Promotion Society of Riga City Council (Šmite 2005: 332). The Latvian Art Promotion Society was founded in 1910 with the purpose of promoting and collecting ethnic Latvian art. One of its aims was also to establish its own library 
and museum (Cielava 1986: 79), partially as a response to the aforementioned problems of exhibiting Latvian works at the City Museum (cf. Lāce 2005: 336; Cielava 1986: 77; Jaunsudrabiņš 1910: 3), and partially as an alternative to the Baltischer Künstler-Verband (Baltic Artists Union), which was not really welcoming towards the majority of Latvian artists (Kencis \& Kuutma 2011: 506). Between the first exhibition of works by ethnic Latvian painters (see below) in 1896, and shared exhibitions of Latvian artists regularly organised by the Latvian Art Promotion Society after 1910, artworks by Latvian artists were displayed both on the prominent premises of Baltic German dominated public art institutions ${ }^{4}$ and multiple other premises such as private salons, bookshops, and artists' studios open to the public, as well as sites of local art education (for a detailed overview see Ābele 2014). The increase in artistic activity was paralleled by the growing printing industry, which greatly contributed to public discourse on art. Latvian, German, and Russian-language periodicals regularly featured exhibition reviews as well as theoretical articles on art. The first years of the twentieth century saw the establishment of extended art sections in magazines like Vērotājs, Austrums, and Zalktis, with high-quality design and reproductions from local as well as foreign artists. Some of the leading Latvian artists, like Janis Rozentāls and Jūlijs Madernieks, also became the main contributors to art criticism.

Regarding style, the fin de siècle decades are called the period of Neoromanticism in Latvian art. In this period realism met strong influences of the Russian Peredvizhniki (Wanderers) artistic group, along with symbolism, postimpressionism, the 'modern style' or Art Nouveau, better known in this region by its German title Jugendstil; some late traits of national romanticism were also still present. As Jeremy Howard notes:

The distinction between styles was far from categorical or exclusive. Many artists experimented with different styles as they searched for their creative identities and markets. Sometimes the search overtly expressed the coincidence with political or national movements. At others it was more personal, subjective, or cosmopolitan. (Howard 1998: 128)

While discussions on inventing a particular 'national style' are covered below, at this moment the variety of genres listed above allows one to speak about a multi-directional cultural translation through the adaption of local content to international form. The process of translation, guided by personal agendas as well as market forces, occurred simultaneously on horizontal and vertical axes. The former represents stylistic adaptations and innovations of a formal nature, applying techniques learned abroad and from foreign sources (books, magazines, visits to exhibitions) to depict real or imagined local realities. The 
latter exemplifies the transfer of images from folklore and ethnography, allocated to the lower rung in the status hierarchy of cultural forms, to the framework of fine arts, which occupy the highest level of the same hierarchy. The fragmentary and multidirectional nature of this process was augmented by lack of history or existing tradition of national art, while at the same time marking a situation unique to the genesis of new cultures in the Baltic provinces as opposite to artistic processes in countries like France, the United Kingdom or Bohemia, where the agency of the fine art tradition was native. The relationship between Latvian national art and its counterparts in other countries was also a constant topic in local critical discourse, with appeals both to modernise the art and not to lose local particularity (Pelše 2007). During the formative process, several coexisting directions of creating national art can be distinguished. Visual art was 'nationalised' either via form - by interpreting ethnographic patterns of ornamentation - or via content. The latter ranges from depictions of local landscapes (Vilhelms Purvītis) and people (early Janis Rozentāls) to motifs of ancient history (Arturs Baumanis), folklore (Ādams Alksnis, Rihards Zariņš) and mythology (late Janis Rozentāls). The developing ethnic visual arts scene became a place of negotiation and exchange between international artistic techniques on the one hand and the construction of national cultural heritage on the other.

\section{FORMAL AND INFORMAL EDUCATION}

The formation of national art outside the 'national territory' was determined by institutional dispositions: there was no art academy or other higher level art education institution in the Baltic provinces. Consequently, the majority of Latvian artists around the turn of the century were trained in St. Petersburg - either at the Imperial Academy of Arts or at Stieglitz's School of Technical Drawing (with an official name: Stieglitz St. Petersburg State Academy of Art and Industry). At the end of the day, "this simultaneous education in the main art centre of Russia became a decisive factor not only in the individual masters' biographies but in the whole creation and development of the national art" (Ābele 2014: 51). It might be that interest in Latvian folklore, shared by artists analysed below, initially developed in this very environment. Here also the first organisation of Latvian nationally-oriented artists (musicians and other students of cultural subjects accompanying the majority of practitioners of fine art) was established. The illegal (due to strict laws on freedom of association) society named $R \bar{u} k, i s$ (The Gnome) was set up and its first meetings took place around the late 1880s, gradually involving almost every successful Latvian artist of the generation. 
Unfortunately, the archives of $R \bar{u} \not h i s$ and multiple other evidences were lost during the turmoil of the twentieth century, leaving future art historians with almost a single source - memories of sculptor Gustavs Škilters (1874-1954). "One of R $\bar{u} \not h i s$ 's main principles was that 'the artist must be a true son of his nation and age'." (Ivanovs 1958: 22) Or, as Škilters wrote: "Highly national spirit and folkish enthusiasm prevailed in R $\bar{u} k, i s . "$ Artists "pursued paths to the heart of the nation each in their own way; researched the folkish ways of expression, and tried to maintain and depict the national spirit, particularity, and tone in their works" (Škilters 1924: 217). The initiative to establish this society came from a less known folklore collector, teacher and publicist Kārlis Alberts Pētersons (1855-1917) (Ābele 2014: 56). The first leader of the artists' society was painter Ādams Alksnis (1864-1897). In the initial years he was one of the oldest representatives in the circles of St. Petersburg Latvian art students; it is rather believable that "due to his education and noble personal characteristics, Alksnis became an authority among Latvian art students and their ideological leader. [---] As a man and an artist, Alksnis notably influenced the new generation of artists. According to testimonies of contemporaries, the rigour of his character, model, encouragements and reprimands have, directly or indirectly, left an indelible imprint on those comrades who were closer to him" (Skulme \& Lapiňš 1954: 55).

As demonstrated in the analysis below, folklore characters and motifs were among the favourite subject matters of Alksnis's oeuvre. If not a direct influence, the artist's example might have been an encouragement to his compatriots to choose a similar direction in creative endeavours, both for regular artwork reviews at $R \bar{u} k, i s$ and during their later career. However, this course was not taken by Alksnis's successor Johann Walter (1869-1932).

Members of $R \bar{u} k, i s$ also constituted the majority of artists whose works were displayed at the first solely ethnic Latvian artists' exhibition in Riga. Such an opportunity occurred in the ethnographic realm, bypassing the space of 'pure' fine art, which was locally dominated by the Baltic German elite. The artworks were put on display during the 10th Pan-Russian Archaeological Congress in Riga in 1896, within an exhibition of Latvian ethnography (Vīksna \& Stradiñ 1997: 107; Ābele 2014: 59). The Latvian Ethnographic Exhibition was opened to the public from August 1st to September 15th, 1896, and was a huge success attended by more than 45,000 visitors. The anonymous author of the exhibition catalogue notes: "Previously artists paid little attention to the life of Latvians; by contrast, the new generation of artists mainly take the subject of their paintings from the life and nature of the Baltic countries" (Howard 1998: 131). However, the participation of nationally minded artists in this event, which at first glance was unrelated to the sphere of arts, was not an exception. As Latvia was just 
a province of the Russian Empire, the national representation at a Pan-Russian event might have been correlated with participation at World Fairs by other, independent countries: the national character was to be found best among the representations of other nations (cf. Hirsh 2003 on the Swiss case). The show at the Ethnographic Exhibition remained the greatest achievement in the joint efforts of the members of $R \bar{u} k, i s$. Later on the group gradually dissolved until its demise in about 1902, as its core members left the capital one by one after finishing their studies. Artists' education in St. Petersburg was usually continued by shorter or longer creative trips to Western Europe, especially Paris, and German creative centres like Berlin and Munich, giving them an opportunity to seize the most recent developments in artistic techniques and aesthetics of new popular styles. After graduation from educational institutions in the imperial capital, many members of $R \bar{u} k$, is moved to their native countryside with the purpose of picturing local landscapes and people. In a regional context, this process is similar to the well-documented Finnish artists' trips to the country's northern periphery - Karelia - constructing the image of the 'nation's cradle' located at a distance from the developed southern regions (cf. Häyrynen 2004; Lonkila 2010), or the German heimatkunst (homeland art) movement. In conclusion, one should agree that "as the group's members went their individual ways, their future relationship with Latvianness, Latvia, and the idea of national art differed widely. Nevertheless, they had created Latvian art as a growing phenomenon and for some of them, working in or for their homeland became an everyday reality" (Ābele 2014: 61). The careers of individual artists demonstrate preferences for particular forms of art, depending on the initial choice of the educational institution, but individual styles seem to be more influenced by later training abroad and other factors. Most likely the shared cultural space unofficially 'institutionalised' by $R \bar{u} \not, i s$ generated interest in national subjects and themes of artworks in spite of art market trends. Still, there was no 'control group' of Latvian artists at the end of the nineteenth century against the backdrop of which this hypothesis could be verified.

\section{SHARED LANDSCAPES AND DIVIDED IDENTITIES}

As the case of outstanding, internationally recognised landscape painter Vilhelms Purvitis (1872-1945) illustrates, the homeland and its everyday reality turned out to constitute complex sets of identities, where political, ethnic, personal, and financial trajectories often intersected in unexpected and inconvenient ways. On the one hand, local scenery and characters provide material for particularly national art only in a somewhat weak sense, i.e. due to refer- 
ences that inform the audience of the artwork. On the other hand, embedded in broader multichannel discourses, native landscapes became the locus of national identity in the late nineteenth century Europe (cf. Facos 2003: 236). Writing on English art history, Stephan Daniels generalises:

National identities are coordinated, often largely defined, by 'legends and landscapes', by stories of golden ages, enduring traditions, heroic deeds and dramatic destinies located in ancient or promised home-lands with hallowed sites and scenery. The symbolic activation of time and space, often drawing on the religious sentiment, gives shape to the 'imagined community' of the nation. As exemplars of moral order and aesthetic harmony, particular landscapes achieve the status of national icons. (Daniels 1993: 5)

The acquisition of this status is sustained by the dual interrelationship of portrayal (verbal or visual) and narration. To become part of national iconography, the same landscape appears in history writings and plays, tourist guides, and epic poetry; it is the subject of paintings and illustrations, and it appears in designs for postage stamps and banknotes. While this can be called the typical way of forging a national symbol, Purvititis succeeded in creating a rather 'essentially Latvian' type of landscape painting, characterised more by form than content.

Usually he painted birch groves or pine stands, snow drifts and ice floes in early spring, blooming trees of May or the colourful foliages of autumn. [---] The variations in the color palette, the softened contours and the technique of the brushwork render Purvitis's landscapes freely painterly, yet the compositional structure is strictly maintained. (Latvian Cultural Canon)

Immediately after graduating from the Academy of Arts in St. Petersburg with a Grand Gold Medal, Purvitis successfully participated in several major international exhibitions, acquiring international recognition and subsequent financial independence. Purvītis's solo shows were organised in Berlin, Dresden, Vienna, London and other art centres across Europe. However, away from the local context, the artist was perceived as, and called, a 'Russian painter' (see Âbele 2014: 89-90), adding one more dimension to his identity. Locally, at the beginning of the twentieth century, Purvitis was equally popular among the new ethnic Latvian middle class and representatives of the historic Baltic German elite, whose members proudly called him "unser landsmann", that is, our compatriot (Ābele 2006: 49). Even more so, in 1905 he wrote with some bitterness about the early years of his career: "German art writers have written about my then still only slightly popular painting in the most promoting way. 
German newspapers, in opposite to Latvian, have never printed any articles against my art." ${ }^{\prime 5}$ (Ābele 2012: 101) Declaring that the interests of art are more important than politics, the artist even spent some time living in Revel (contemporary Tallinn, Estonia) around the time of the 1905 revolts, due to unwillingness to take part in the events that had divided Latvian society into two radically opposite parts. Multiple publications on local art around the turn of the century (analysed in Ābele 2006, 2012; Pelše 2007) allow for a reconstruction of the hybrid domain of artistic practices, in which the same artists and their works can be denominated as Latvian and also as Baltic, with reference to the Baltic German notion of territorial identification. Public recognition and subsequent financial benefits proved Purvītis's success. Despite the dominance of the genre at exhibitions, no other artists succeeded in turning their landscapes into national symbols. Scenic paintings by Rozentāls and Walter remain in the background of their oeuvre while the nonconformist postimpressionist painter Voldemārs Zeltin̄š (1879-1909) deliberately avoided entering the art market. The weak link between the type of landscape and the desired expression of 'national spirit', recalled in Škilters's memories of Rūkis, demanded that artworks develop an alternative, more nationally particular content. And the discourse of folklore and ethnography provided such content, undisputedly Latvian, for the general public.

\section{WHY FOLKLORE}

The devil is one of the most popular characters in Latvian folktales and legends. In some tales he is a cunning, exquisite gentleman, dressed all in black and betrayed only by the goat footprints he leaves behind; in some others he is a monster with multiple heads. Many tales feature him as a hairy and naïve antagonist of God, always ending up as a fool. The latter image of the folk devil is represented along with other characters of folklore in the works by Âdams Alksnis, the first leader of $R \bar{u} k, i s$. The national character of Alksnis's oeuvre, contrary to Purvitis's landscapes, was not hidden in a specific use of stylistic devices or an original palette of colours. It was the content, the narrative of artworks that in 1904 allowed another great artist and art critique, Janis Rozentāls, to call him "the pioneer of true Latvian art" (R. 1904: 501). Alksnis, a student from the battaglia ${ }^{6}$ master class under the guidance of Bogdan Willewalde (1819-1903) at the Imperial Academy of Arts in St. Petersburg, devoted multiple works to compositions from the Baltic (including Latvian) history and historical warfare; typical examples in this regard are Senlatviešu kauja ar bruniniekiem (The Battle of Ancient Latvians and Knights, around 1890) 
and Izlüki (Scouts, mid-1890s). While Alksnis was also among the first artists to depict rural scenes and local types, his heritage of around 800 drawings, watercolours, and paintings includes works on other folklore motifs in addition to the devils mentioned above. For example, his picture Jātnieks pils priekš $\bar{a}$ (Rider in Front of the Castle, around mid-1890s) would, according to Rozentāls, be a good "fit for the illustration of a common phrase in our fairy-tales: 'and by darkness approaching, he suddenly saw in front of him a beautiful castle" (ibid.). It was by the same time that Latvian folklorist Ansis Lehris-Puškaitis had already published the first volumes of one of the basic collections of Latvian folklore, Latvian Folktales (1891-1903), consisting of almost 7000 fairy-tales and legends in total.

The relatively intense exploitation of folkloristic motifs in the works of Latvian artists was not coincidental. It was related to the special role of folklore in the articulation of national identity and culture. Commenting on the ideological currents born in Europe from Johann Gottfried Herder's famous celebration of folk culture, Joep Leerssen says:

What is more, it alerted all nations that were as yet without established 'high literature', that their cultural output, even if it took the (hitherto despised) form of oral folksong, was nonetheless a thing to be proud of, a manifestation of the nation's presence in the cultural landscape. (Leersen 2006: 100; cf. Bula 2008)

Already since the formation of nationalistic views in the mid-nineteenth century, there had been an increasing public demand for national culture that would express particularly ethnic Latvian imagery. Collections of folklore were among the first manifestations of national culture, inseparable from the cultural political agenda of liberating the nation. The end of the nineteenth century saw simultaneous publications of the largest collections of folksongs and folktales. Thus folklore was approved and celebrated as a national particularity at a time when an ethnically conscious generation of Latvian artists entered the stage of history. Consequently, one way in which the demand for national fine arts resulted was the borrowing of themes and images from folklore and mythology. However, Latvian national artists were awaited not only by the existing discourse on folklore, but also by foreign models of its adaptation into techniques and modes of visual arts. In this regard one of the geographically and politically closest trendsetters was Finland, extensively analysed by Pertti J. Anttonen (2005) and Derek Fewster (2006). This was not only through the influence of Finnish artist Akseli Gallen-Kallela, described in detail below, but also through the general image of Finnish cultural heritage. The latter served 
as a point of reference in the illustrious call for national mythology-inspired arts by art critic Jānis Liepiṇš as late as 1916:

But does our life lack substance, great events? And if not life, then Latvian mythology has stocked up great treasures of the Latvian soul over long centuries, providing rich matter and national themes for painting and poetry. Still, do we have a single character as the Finns have Väinämöinen and others? But Latvians have "wonderfully lovely antiquity" with the Latvian Bearslayer, the Devil, and the Thunder God with six sons who glance through the roses, and daughters of the moon. And in the northern sea, in a cold castle, the North Father rules with his daughter, and the tender-hearted God, walking upon the earth, doing good to everyone. [---] That is the world that locks the Latvian soul into symbols, a particular and infinitely beautiful world, and when diving into such a story, an individual artist can gain worldwide recognition. But foreigners ask about our art: Where does its particularity lie? (Liepiňš 1916: 1)

Despite Liepiṇš's journalese request, art history demonstrates that before 1916 folklore and mythology motifs were rather well represented in Latvian arts. For example, Alksnis was followed by his successor at the head of the Rūkis society, graphic artist Rihards Zarin,š (1869-1939), although already on a different scale and with much more proficiency. A graduate of Stieglitz's School of Technical Drawing in 1895, Zariņš continued his education in Berlin with graphic artist and illustrator Alexander Zick (1845-1907), in Munich with Rudolf von Seitz (1842-1910) and Maximillian Dasio (1865-1954), and in Vienna with William Unger (1837-1932), as well as studied lithography in Paris. Zariṇš later lived in St. Petersburg until 1919, which allows, with some certainty, to trace in his works the influence of the stylistic devices developed within the Russian modern group, Mir iskusstva (World of Art). For example, particular similarities appear in Zariņš's illustrations of fairy-tales and the works of Ivan Bilibin (1876-1942), illustrator, ethnographer, stage designer, and the author of the monograph Folk Arts of the Russian North (1904). Despite living abroad, Zariņ̌s actively participated in Latvian art life, illustrating books and periodicals, gathering ethnographic material and participating in exhibitions. During the last decade of the nineteenth century he explored a historically-decorative style close to German romantic tradition, also creating a well-known first example of pure Latvian national romanticism, the title page for a Latvian folksong edition, Latvju dainas, in 1894. Developing a synthesising approach to the modern style, Zariņš "made frequent redress to literary analogy and narrative" (Howard 1998: 137). A reviewer of his first exhibition in Riga in December 1899 emphasised: 
As a narrator of fairy tales and an illustrator, he combines a vigorous imagination with an outstanding decorative talent and graphic ability. The mysteries of the forest, goblins and elves, enchanted princesses guarded by ghastly dragons - all this and the like is presented in a pleasant, attractive manner. (ibid.)

Zariņš authored allegorical representations of folklore, like Tautasdziesma (Folksong, 1892) and Pasaka (Fairy-tale, 1898), and depicted ancient Latvian gods like Pērkons (Thunder God, 1904), although his favourite subject still seems to have been scenes from folktales. He also created a series of works dedicated to one story, and was keen on making purely decorative drawings of all kinds of mythological beings from fairy-tales, such as gnomes, devils, mermaids, and dragons.

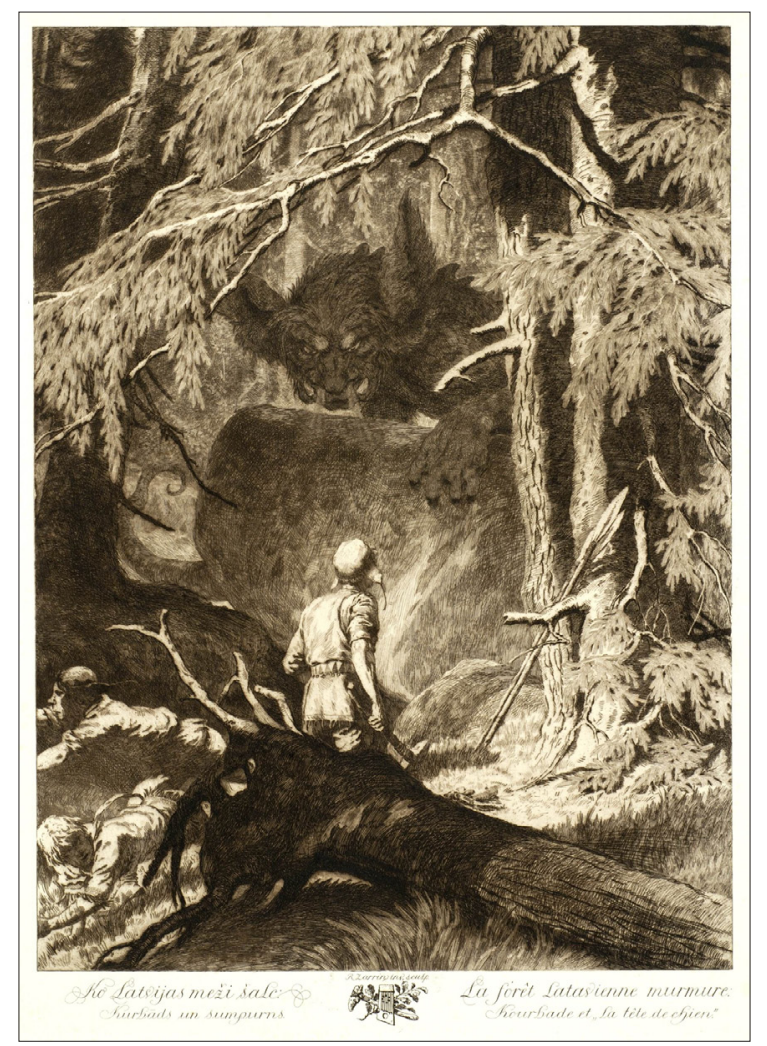

Figure 1. Rihards Zariņš. Kurbads un sumpurnis (Kurbad and Cynocephalus, 1908-1911). Latvian National Museum of Art. 
The history of various European countries demonstrates an extremely varied interest in folklore and the development of folkloristics as a discipline (cf. Ó Giolláin 2000). As such it might be correlated with the development of the discipline of history and the discovery of historical sources. The same also applies to visual arts: where traditions of historical painting bloomed, folklore gained much less prominence. An overview of the cultural developments of the (early) nineteenth century indicates: "In the field of painting and sculpture, themes from national history had become dominant, celebrating the glories and glorifying the tragedies from the nation's annals" (Leerssen 2006: 188). However, this tendency seems to have reached Latvia only in the last decade of the century. Several historical scenes, especially those related to ancient warfare, were created by Âdams Alksnis, although the paintings of Arturs Baumanis (1867-1904) gained more prominence in this regard. Baumanis, who was a student of the Imperial Academy of Arts, borrowed many stylistic devices from the most prominent German masters of academic historical painting, such as Wilhelm von Kaulbach (1805-1874), Alfred Rethel (1816-1859), and Karl von Piloty (1826-1886) (Latvijas mākslas vēsture). Baumanis's most famous painting Likten,a zirgs (The Horse of Destiny, 1887) (Fig. 2) is close to the manner of the Dusseldorf school, and like another large-scale historical composition, Kurši sadedzina savus mirušos (Couronians Burn Their Dead; end of the 1880s), illustrates a scene from the medieval Heinrici Chronicon Lyvoniae, recently translated into Latvian. Apart from these, Baumanis was commissioned by the Riga Latvian Society - the central cultural-cum-political institution of nationforming - to create a series of portraits of outstanding personalities from the national movement. His oeuvre also includes drawings on ancient Latvian history and illustrations to the epic poem Niedrīšu Vidvuds by Jēkabs Lautenbahs (1848-1928). For some time the latter was the main contestant for the honour of being the national epic, like the Finnish Kalevala or Estonian Kalevipoeg. Overall, Baumanis and Alksnis stand out in the construction of national art at the end of the nineteenth century as two authors developing the genre of historical painting. At the same time, they were the only members of the $R \bar{u}, k i s$ society who left the Academy of Arts before the Peredvizhniki reform of 1894; therefore their interest in historical scenes coincides with the curricula of prereform academia. Unfortunately, the premature deaths of both painters left these waters still for about two decades, while their contemporaries chose different styles and subjects for their creative endeavours. The lack of exemplary historical events worth national appraisal and celebration left a discursive gap in the construction of national identity, the latter being notably constituted by shared memories as a form of history. In Latvia, this gap, to some extent, was filled by an already accumulated symbolic capital of folklore. One can say that 


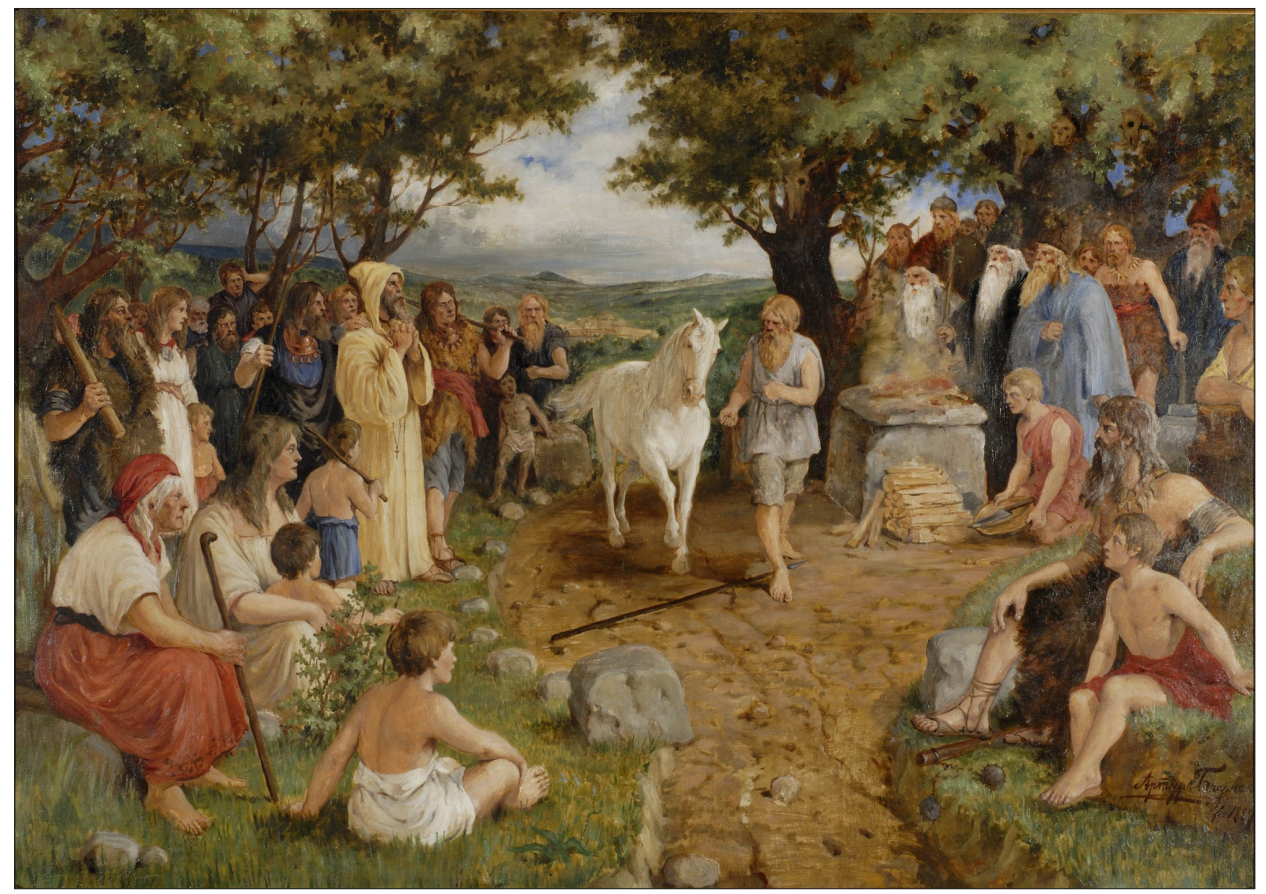

Figure 2. Arturs Baumanis. Liktena zirgs (The Horse of Destiny, 1887). Latvian National Museum of Art.

folklore filled the niche between two opposites (when talking of its value for nation-building) on the axis of national content in art: the anonymous landscape of the native land and the heroic events of the past.

\section{STYLE AND ORNAMENT}

In this regard, folklore went hand in hand with interest in ethnic tangible culture or, more precisely, folk ornament. While folklore materials are narrative and, as such, restricted to the narrative genres of art such as painting, drawing, and sculpture, folk ornament provides a wider choice of expressive forms within the realm of applied design. It might be awarded less prestige in the common hierarchy of arts, but at the same time it reaches a considerably wider market than constituted by elitist purveyors of painting and visitors to art exhibitions. The local blooming of the production of applied design items 
was related to a rapid increase in demand in the Baltic provinces, the most advanced region of the empire. Particular developments can be associated with two somewhat contradictory tendencies: the growing popularity of the modern style and the international Arts and Crafts Movement, established by artist and writer William Morris (1834-1896). According to Morris, design had to return to the organic simplicity of craftsmanship, adapting it to the spirit of time. Nationalisation of design was related more to decorations and patterns than the shapes of objects and materials; it drew inspiration and motifs from the ethnographic ornament, richly preserved in the fabrics of traditional folk costumes. In this regard a rather fierce public discussion occurred between two members of the Rūkis society - Jūlijs Madernieks (1870-1955) and Rihards Zariņš. Madernieks felt rather free regarding the stylisation of ethnographic ornaments and motifs, while Zariņš insisted on deeper studies of visual heritage and fewer changes during its adaptation to contemporary means.

According to Jeremy Howard, after the turn of the century Madernieks became Latvia's leading universalist, practicing graphic arts, embroidery, furniture and interior design as well as painting, teaching, and art criticism (Howard 1998: 134). Madernieks studied decorative painting at Stieglitz's school and later completed his study of professional standards in Paris, Munich, and London, thereafter settling in Riga in 1902. Akin to Swedish painter Gustaf Fjaested (1868-1948), whose works Madernieks is known to have studied, his landscapes echo modern style characteristics; his interiors designed from the first years of the twentieth century are also similar (ibid.). While in his early works Madernieks freely combined ornamental styles like those of traditionally Byzantine or Oriental and natural forms, his preferences later shifted more towards geometric patterns resembling Latvian folk ornament. Analysing Madernieks's writings on art theory, Latvian art historian Stella Pelše deduces that "Madernieks's ideas expose both elements of the aestheticist position of art's autonomy and references to art as the expression of the nation's collective spirit that can be traced back to Herder" (Pelše 2007: 42). Indeed, Madernieks himself wrote:

We only start to recognise a nation's cultural face if its art manifests the wonderful essence, which, like language, allows us to distinguish one nation from another. The more organically healthy and stronger the nation, and the more intense the impulses of national specificity, the more original an artist's work will be. (Madernieks 1914 (287): 2)

Despite using similar metaphors, Herder's influence here is doubtfully direct (cf. Baar 2010: 112). However, it cannot be dismissed as purely coincidental. Folksong collections of Herder's first Baltic correspondents established practices that were later directly continued by the emerging Latvian nationalists. At the 
end of the day, "the symbolic link between nation and oral poetry posited by Herder has had an enormous intellectual and political influence in the history of Latvian national identity, with its central symbolic image of the "nation of singers"' (Bula 2008: 7). This particularity of the nation-building served as a basis for the use of oral poetry, i.e. folklore, motifs in artworks of Latvian artists who contributed to the ongoing nation-building process at the same time. Naturally, Madernieks implemented his ideas of national art in his studio, where at some point he was teaching up to fifty students. Remembering the time before World War I, the artist recalls: "I tried to arouse interest in my pupils regarding our ancient spiritual world - folktales, folksongs, etc. I even assigned particular themes for sketches of compositions" (Madernieks 1940: 7). However, his own loose and sometimes only suggestive use of Latvian ornament provoked a fierce response from Zariňš, expressed in a series of articles in the press as well as in a letter to Rozentāls. The latter, cited also by Howard (1998), is worth quoting here in length to illustrate the nature of discussions about national heritage in contemporary art:

I have decided to go to war in the newspapers against Madernieks. Because it's nonsense to suppose you can modernise your national dress. Then it's not national dress any more. And when have you heard of any nation who has done it? You can modernise "Reform" clothes as much as you like - that's happened in Finland, Sweden and Norway. But no one has changed national costumes. Yet Madernieks does not feel that it is against the style. Just as he does not sense that you cannot mix Latvian woollen shawl ornaments with Russian book decoration - which is what he has done, on the Tālavietis invitation cards. [---] I am sure that Madernieks will be rude to me, even though my criticism is given with the best intentions... He will say that I am a shameless overseer, a Genghis Khan who suppresses freedom. But he does not realise how lacking in taste his work is. He needs about six overseers. (Howard 1998: 136)

Public discussions between Zariņš and Madernieks in several magazines and newspapers lasted for about a year, but final agreement was never reached and both approaches to cultural heritage, represented by these artists, continued to coexist well after World War I (cf. Ābele 2014: 98). Differences in approach to the stylisation of ornaments are quite distinctive in magazine contributions by both artists: designs in Zalktis (1907-1910) and Vērotājs (Wehrotajs, 1903-1905) by Madernieks and in Druva (1912) by Zariņš (all available at www.periodika.lv). Otherwise, the opinions of both artists are more comparable than their works due to difference between Madernieks's specialisation in interior and textile design and Zarinššs commitment to delicate visuals such as the designs of bank 
notes, stamps, and securities. Zariņš, in his decorative (as opposed to narrative, analysed above) works tried to remain faithful to ethnographic designs and to represent them more clearly, without distortion or mixing them with foreign traditions. Zariňš's revivalist stance also bears a resemblance to some of the core ideas of Herder, who wrote on the relationship of symbolic representational systems (like language and culture) and the regional specifics of nature and climate (e.g. Herder 2002: 150). In the same way Zariňš called for the creation of art that "has grown on the fundaments of ancient people's art and is adequate to the climate of the land and living conditions of the people" (Zariňš 1904: 148). Interestingly enough, his own works are not limited to the reproduction of old forms, instead representing distinct characteristics of modern style. Despite the obvious, Zariņš declared:

We will be aware not to spread that international plague of arts that fancies to call itself modern style, but in reality is not anything else than a style without a theory, a composition of pieces from English, German, and French art magazines. (ibid.)

In his later years, authoring a fundamental three-volume edition of Latvian ethnographic folk ornament (1924-1931), Zariņš could be compared with one of the establishers of the Estonian National Museum, Estonian artist Kristjan Raud (1865-1943). Both artists, representing the second generation of their respective nations, emphasised and practised research and collection of visual heritage, leaving its contemporary developments for later times (cf. Seljamaa 2006).

\section{SYMBOLISM AND DIVERSITY}

The most versatile relationship between the imagery of folklore and visual forms of fine arts is to be found in the legacy of Janis Rozentāls (1866-1916). Here we can see not only transmission of images from one discursive realm to another, but also a translation into the international language of fine arts, the latter emphasising parallels of folklore collection on the one hand and its creative visualisation on the other. Rozentāls was a distinguished artist and intellectual of his time, practising painting, graphic design, applied arts, teaching, and art criticism, to a large extent leading the local discourse on art theory in Latvia in the first decade of the nineteenth-century (cf. Rūķe-Draviṇa \& Tārs 1989; Howard 1998; Pelše 2007). He studied painting at the Imperial Academy of Arts in St. Petersburg from 1888 to 1894, at a time when the academy was being reformed and artists representing the realistically (as opposed to the classical 
academic tradition) oriented Peredvizhniki movement took teaching positions, the latter including Rozentāls's tutor Vladimir Makovsky (1846-1920). The reform created an opportunity for the students to freely choose the subjects of their compositions, which were no longer restricted by the framework of the classical programme. It could be the everyday reality or images from the realms of fantasy or folklore (Ābele 2014: 53). However, after the first nationalrealistic compositions with some traits of impressionism, Rozentāls explored a more conceptualist vocabulary in his oeuvre, merging national romanticism, symbolism, and post-impressionism. During his studies Rozentāls was an active member of the $R \bar{u} k, i s$ society and one of the main organisers of the Latvian art display at the aforementioned ethnographic exhibition. In a way, his paintings and drawings of fauns, satyrs, and devils, for example Pēc pirmajiem gailiem (After the First Cock-Crow, ca. 1905), can be regarded as a contribution to a friend and the $R \bar{u}$ ķis leader, Ādams Alksnis. However, compared to Alksnis or Zariňš, "Rozentāls's approach was more subjective, relying on a heightened individual interpretation of the surrounding reality and a lessened reliance on the conventions of stylisation" (Howard 1998: 139). Rozentāls was a renowned portraitist, while his figural compositions often refer, directly or allegorically, to Latvian folklore. Rozentāls's oeuvre is a prime example of the interplay of international formal qualities with both real and symbolic local content. However, some folklore motifs are so international that they cannot be attributed to a particular national tradition. Such as personified death in the eponymous painting Nâve (Death, 1897), merging the social realism of the late Peredvizhniki with the symbolists' mythical image in the haunted clarity of midday light, a time when, in Latvian folklore, the supernatural manifests itself as frequently as at midnight. Of similar uncertainty, regarding the original source, is another folklore-related painting, Gulbju jaunavas (Swan Maidens, ca. 1906). The same subject of merged human and animal features was also dealt with by famous Russian symbolist Mikhail Vrubel (1856-1910) in his 1900 masterpiece, Swan Princess. The subject of the painting is an internationally widespread folktale, listed in the Aarne-Thompson tale-type index under number 400. Of even more complex origin is Rozentāls's painting Teika (The Saga, 1899) (Fig. 3), featuring a naked female harpist against the background of the sea. Jeremy Howard indicates that the image might be related to Latvian deities of the sea, wind, or destiny (Howard 1998: 142). However, the only certain affinity that the image bears is a resemblance to La Muse (1898) by Henri Martin, the immensely popular painting shown at the Salon des Artistes Français the same year that Rozentāls visited Paris.

A more direct and certain reference to Latvian folklore is provided in two paintings by Rozentāls: the post-impressionist Saules meitas (Daughters of 


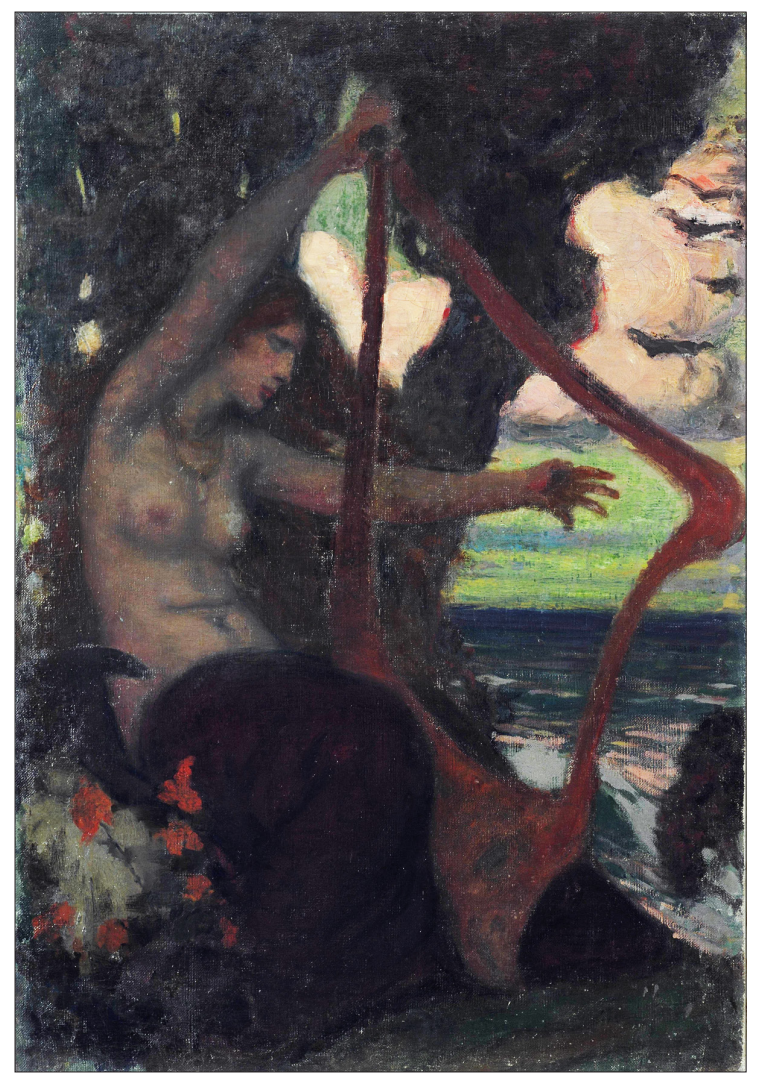

Figure 3. Janis Rozentāls. Teika (The Saga, 1899). Latvian National Museum of Art.

the Sun, 1912), depicting well-known Latvian mythical beings in an idyllic, sunlit environment, and Melna čūska miltus mala (The Black Snake Ground Flour, 1903) (Fig. 4). The latter is stylistically close to the works of the then famous Swiss symbolist Arnold Böcklin (1827-1901), the author of paintings that capture attention with dark, mythical, and sea-related imagery. Moreover, Rozentāls also authored an article on Böcklin in the monthly magazine Vērotājs (R. 1903). The title of Rozentāls's work is a reference to a Latvian folksong: "The black snake ground flour / in the middle of the sea, on a stone / that will be served to masters / who forced to work with no sun" (Krišjāṇa Barona Dainu skapis, No. 31348). The idea of the painting might be related to the suspense before the revolts of 1905 (see, e.g., Cielava 1974: 41). Interestingly, the same particular folksong motif was reproduced by another Latvian artist Rūdolfs 
Pērle (1875-1917) around 1916. Living in St. Petersburg after graduating from Stieglitz's school, Pērle established a distinctive style of his own, in later years developing imagery close to that of Lithuanian artist Mikalojus Konstantinas Čiurlionis (1875-1911), whose already famous works he might have seen in several exhibitions in St. Petersburg (Lamberga 2014: 60). Pērle worked in various media, for example watercolour, oil, etching, and others, depicting various subjects from purely decorative floral compositions to complex symbolic narratives. The Black Snake is not the only one of Pērle's works that refers to folksongs: Kara karodzina rakstittajja (Embroiderer of the War Flag, 1916) both illustrates a recognisable folklore motif and bears ethnographic ornament within the composition; the choice of words in the Latvian title of Saulìt vèlu vakarā (The Sun Late in the Evening, 1916) indicates a folksong; the same applies to the mythological motifs of Saules dèli karā jāja (The Sons of the Sun Rode into Battle, 1917). It seems that the artist's interest in particularly national (and, in two out of four, militant) subjects might have been related to the recent outbreak of World War I, which ravaged his native land of Latvia.

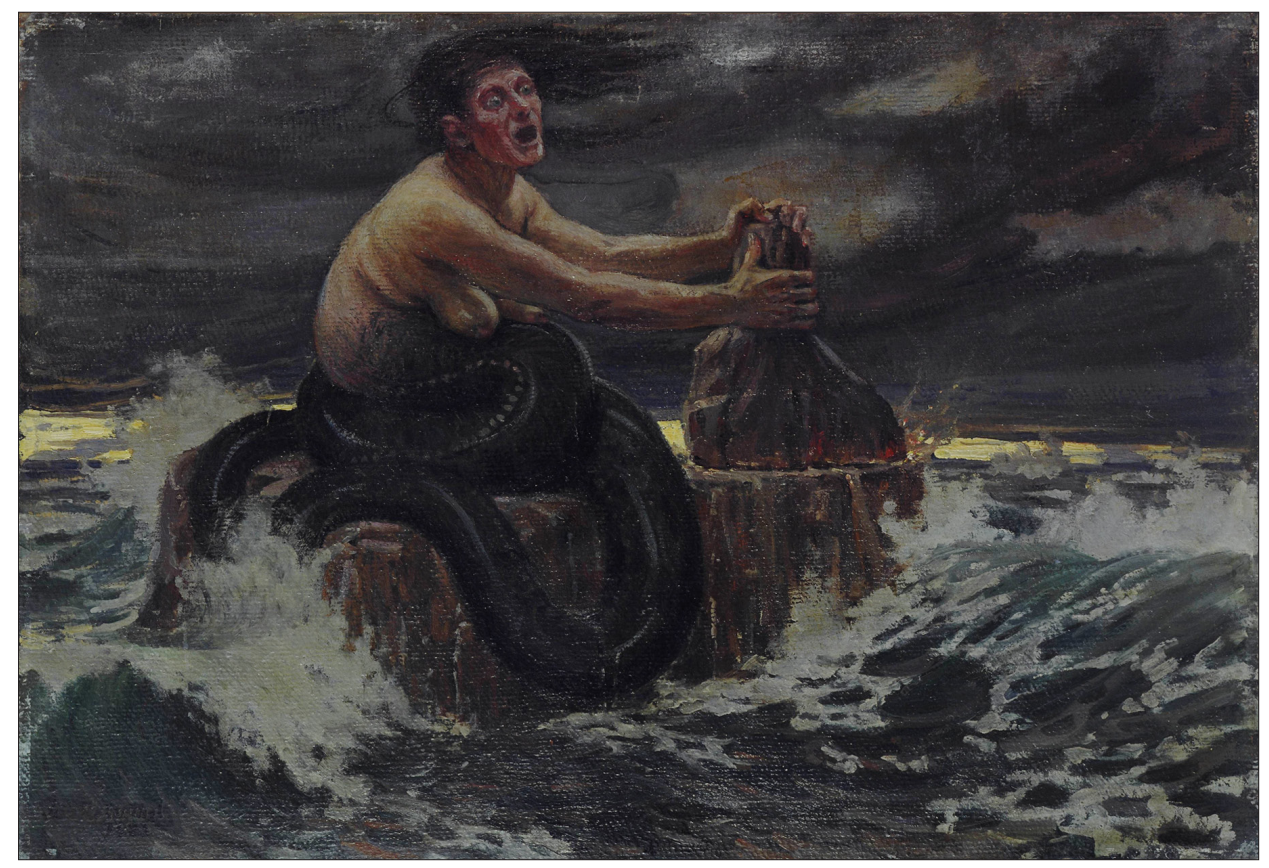

Figure 4. Janis Rozentāls. Melna čuska miltus mala (The Black Snake Ground Flour, 1903). Latvian National Museum of Art. 
The first lines of the folksong Kas tie tādi, kas dziedāja (Who Were Those Who Sung, 1913), and the names of the works of Rozentāls and Pērle, Melna čūska miltus mala (The Black Snake Ground Flour, ca. 1910) are also titles of artworks by another member of the Rūķis, Gustavs Škilters, Pērle's schoolmate at Stiglitz's School of Technical Drawing and later a student of French sculptor Auguste Rodin (1840-1917). Šķilters shares the titles Lietuvēns (Nightmare, 1910) and Gulbja meita (Swan's Daughter, i.e. the motif of the Swan Princess, 1911) with Rozentāls.

Returning to Rozentāls, two of his works are definitive in aligning international connections, stylistic innovations, and personal agenda in creating essentially national art. One such is the painting Vel̦ laiva (The Boat of Dead Souls, ${ }^{7}$ ca. 1905). The painting in many ways resembles The River of Death (1903) by Finnish painter Axeli Gallen-Kallela (1865-1931), who was "indeed the central figure in the resurrection of the so-called 'Kalevala art' in the 1890s" (Fewster 2006: 224). The importance of the folklore-based national epic Kalevala in Finnish nationalistic imagery is inestimable, and the symbolic charge that Kalevala-related art bears can surely inspire recreation of the same effect in other national traditions. Rozentāls visited Finland for the first time in 1896, sponsored by the Riga Latvian Society (Rūḳe-Dravina \& Tārs 1989: 27). He had probably also seen Gallen-Kallela's mural The Advent of Christendom or Christendom and Heathendom in the Finnish pavilion at the Paris Universal Exhibition in 1900. "Even in itself the Finnish pavilion was a statement of the political strength of Finnish nationalism, and displaying a praise of pagan culture bears testimony to the status Gallen already had as a "national painter" (Fewster 2006: 226). The artist definitely visited all three exhibitions of Finnish art held in Riga in 1901 and 1902, even though Rozentāls's relationship with Finnish culture became personal in 1903 when he married a Finnish opera singer, mezzo-soprano Elli Forsell (1871-1943). A few months before the marriage, Rozentāls wrote to his future father-in-law:

All your culture, particularly the art, is a sort of model for me. And being a painter, I most admire your great masters Gallen, Järnefelt, Hallonen, Saarinen and others, and my deepest longing is to become something of their kind here in Latvia. (Translated in Howard 1998: 144)

In subsequent years the artist often visited Finland, becoming personally acquainted with his idols and other Finnish intellectuals. Some researchers even claim that Pekka Halonen (1865-1933), renowned painter of Finnish national heritage, learned German with the purpose of conversing with Rozentāls (RūkeDraviṇa \& Tārs 1989: 31). 
The Finnish model is quintessential for the most monumental and, in a way, the most national of Rozentāls's works - a mural of seven friezes, made of coloured cement and mosaic, on the façade of the new building of the Riga Latvian Society (1910). The society, established in 1868, was at the time the centre of the Latvian national movement. The building, designed by Latvian architects Ernests Pole (1872-1914) and Eižens Laube (1880-1967), still occupies a prominent position on a boulevard at the very centre of the city. Referring to Latvian pagan mythology, these paintings "were in many respects Rozentāls's response to Gallen's Kalevala frescoes for the Finnish Pavilion in Paris ten years earlier" (Howard 1998: 144). Rozentāls's aim was to layer together four levels of symbolic meanings: pagan gods, who together represented the independent, ancient Golden Age of Latvians. Each god separately represents universal stages of the human lifecycle and human virtues: the Thunder God Pērkons represents maturity and power, Potrimps - youth and beauty, and Pīkols - old age and wisdom. Similarly, they represent the basic tripartite Indo-European cosmology: heaven, earth, and the underworld, respectively related to weather, fertility, and death. The fourth layer of symbolism refers to the activities of the Riga Latvian Society - art, science, industry, and agriculture. The deities painted by Rozentāls belonged to the national romanticist pantheon, as described in the poetry of Auseklis (Mikelis Krogzemis) (1850-1879) and in the national epic Lācplēsis (Bearslayer, 1888) by Andrejs Pumpurs (1841-1902). However, in the decades after the completion of Rozentāls's monumental work, the scholarly researchers of Latvian mythology unanimously agree that Pīkols and Potrimps were not genuine Latvian deities, but uncritical romanticists' borrowings from Prussian and Lithuanian sources (e.g. Šmits 1926).

Overall, Rozentāls skilfully balanced the local cultural capital of folklore and international recognition of mythical subjects of Symbolist art, ethnic national sentiments and close comradeship within the Baltic German society, creative work and creation of critical discourse, national uniqueness and following the best foreign examples. His artworks clearly illustrate the fact that national art shares the ambivalent nature of nationalism, which claims to be unique in any country, related to one particular land, language, nationality, and other properties; at the same time, the structure and mechanisms through which nationalism functions are very similar from country to country. In the meantime, comparative studies of art like this reveal broader field-specific dynamics: the interplay between the discursive realms of different statuses, ideals and markets, personal agendas and fashions for international styles, the layered fusion of international and national motifs. The Latvian case of the nationalisation of art around 1900 demonstrates specific recourse to folklore as an established and celebrated symbolic resource of national identity. 


\section{ACKNOWLEDGEMENTS}

Research for this article was supported by European Social Fund project, Cultures within a Culture: Politics and Poetics of Border Narratives.

\section{NOTES}

1 According to approximate data from the census of 1897, the Latvian-speaking population was $68.3 \%$, the Russian-speaking $-8 \%$, and the German-speaking $-7.1 \%$. The remaining largest minorities were Jews, Belarusians, and Poles, all together constituting 13.9\% (Bērziñ š 2000: 108). Almost $70 \%$ of the working population was employed in trade and farming (ibid.: 109).

2 The German Latvian Literary Society with the Latvian title, the Latvian Friends' Society (with all the colonial connotations this title bears), established in 1824 .

3 The German Provinces of Russia were industrially the most developed region in the Russian Empire, therefore urban areas were populated by rapidly increasing numbers of ethnic Latvian proletarians, the main audience for the whole range of politically left organisations from centric socialists to radical Bolsheviks.

${ }^{4}$ Including the opening exhibition of the Riga Art Society Salon, where in 1898 an honourable place was occupied by the works of Vilhelms Purvitis, the most famous Latvian (and Baltic) artist.

5 Quoted from Ābele 2012, originally published in a currently unavailable supplement of Düna-Zeitung from 1905, No. 179: 1.

6 War-related paintings.

7 In the Latvian title “...of dead souls" uses the distinctively folkloristic term velu. In Soviet historiography the painting is also known as The River of Death.

\section{REFERENCES}

Ābele, Kristiāna 2006. Tautieši un novadnieki. Nacionālais jautājums un teritoriālā identitāte Latvijas mākslas dzīvē 19. gadsimta beigās un 20. gs. sākumā. [Fellow Nationals and Compatriots: The National Question and Territorial Identity in the Art Life of Latvia in the Late 19th and Early 20th Centuries.] In: D. Lāce (ed.) Mākssla un politiskie konteksti. [Art and Political Contexts.] Rīga: Neputns, pp. 39-63.

Ābele, Kristiāna 2012. Autoru meklējumos: Mākslas kritik̦i Baltijas un Pēterburgas vācu presē 19.-20. gs. mijā un viṇu dalība latviešu mākslas popularizēšanā. [Attribution of Authorship: Art Critics in the Baltic and St. Petersburg German Periodical Press around 1900 and Their Contribution to the Promotion of Latvian 
Art.] In: K. Ābele (ed.) Personība mākslas procesos. [Personality in the Processes of Art.] Rīga: Neputns, pp. 98-124.

Ābele, Kristiāna 2014. Artistic Life. In: E. Kḷaviṇš (ed.) Art History of Latvia IV: Period of Neo-Romanticist Modernism 1890-1915. Riga: Institute of Art History of the Latvian Academy of Art, pp. 31-173.

Anderson, Benedict 2006 [1983]. Imagined Communities. London \& New York: Verso. Anttonen, Pertti J. 2005. Tradition through Modernity: Postmodernism and the NationState in Folklore Scholarship. Helsinki: Finnish Literature Society.

Baar, Monika 2010. Historians and Nationalism: East-Central Europe in the Nineteenth Century. New York: Oxford University Press.

Bērzin̄š, Valdis (ed.) 2000. 20. gadsimta Latvijas vēsture: Latvija no gadsimta sākuma lìdz neatkarības pasludināšanai 1900-1918. [Latvian History in the 20th Century: Latvia from the Beginning of the Century to Independence 1900-1918.] Rīga: Latvijas vēstures institūta apgāds.

Bula, Dace 2008. Latvian Folksongs: Collected, Published and Studied. In: D. Bula \& S. Rieuwerts (eds.) Singing the Nations: Herder's Legacy. Trier: Wissenschaftlicher Verlag Trier, pp. 7-29.

Cielava, Skaidrīte 1974. Latviešu glezniecība buržuāziski demokrātisko revolūciju posmā (1900-1917). [Latvian Painting in Period of Bourgeois-Democratic Revolutions (1900-1917).] Rīga: Zinātne.

Cielava, Skaidrīte 1986. Latviešu tēlotāja māksla: 1860-1940. [Latvian Fine Arts: 1860-1940.] Rīga: Zinātne.

Daniels, Stephen 1993. Fields of Vision: Landscape Imagery and National Identity in England and the United States. Princeton: Princeton University Press.

Facos, Michelle 2003. Educating a Nation of Patriots: Mural Paintings in Turn of the Century Swedish Schools. In: M. Facos \& S.L. Hirsh (eds.) Art, Culture, and National Identity in Fin-de-Siècle Europe. Cambridge: Cambridge University Press, pp. 229-249.

Fewster, Derek 2006. Visions of Past Glory: Nationalism and the Construction of Early Finnish History. Helsinki: Finnish Literature Society.

Häyrynen, Maunu 2004. A Periphery Lost: The Representation of Karelia in Finnish National Landscape Imagery. Fennia, Vol. 182, No. 1, pp. 23-32. Available at http://ojs.tsv.fi/index.php/fennia/issue/view/627, last accessed on July 22, 2015.

Herder, Johann Gottfried 2002. Philosophical Writings. Translated and edited by Michael N. Foster. Cambridge: Cambridge University Press.

Hirsh, Sharon L. 2003. Swiss Art and National Identity at the Turn of the Twentieth Century. In: M. Facos \& S.L. Hirsh (eds.) Art, Culture, and National Identity in Fin-de-Siècle Europe. Cambridge: Cambridge University Press, pp. 250-285.

Howard, Jeremy C. 1998. Latvian National Romanticism and Art Nouveau: Origins and Synthesis. In: E. Grosmane (ed.) Romantisms un neoromantisms Latvijas mākssāa. [Romanticism and Neoromanticism in Latvian Art.] Rīga: AGB, pp. 128-153.

Hroch, Miroslav 1985. Social Preconditions of National Revival in Europe. Cambridge and New York: Cambridge University Press.

Ivanovs, Miķelis 1958. Gustavs Š ̦̌ilters. Rīga: Latvijas Valsts izdevniecība.

Jaunsudrabiṇš, Jānis 1910. "Baltijas mākslinieku biedrība" un latviešu mākslinieki. [Baltic Artists Association and Latvian Artists.] Latvija, Vol. 10, p. 3. 
Kencis, Toms \& Kuutma, Kristin 2011. National Museums in Latvia. In: P. Aronsson \& G. Elgenius (eds.) Building National Museums in Europe 1750-2010. Conference Proceedings from EuNaMus, European National Museums: Identity Politics, the Users of the Past and the European Citizen, Bologna 28-30 April, 2011. Linköping: Linköping University Electronic Press, pp. 497-519. Available at http://www.diva-portal.org/smash/get/diva2:450373/FULLTEXT01.pdf, last accessed on July 22, 2015.

Kḷaviņš, Eduards 1996. Latviešu portreta glezniecība 1850-1916. [Latvian Portrait Painting 1850-1916.] Rīga: Zinātne.

Krišjān,a Barona Dainu skapis. [Cabinet of Folksongs of Krišjānis Barons.] Available at www.dainuskapis.lv, last accessed on November 5, 2015.

Lāce, Māra 2005. Museum Time: 1918-2005. In: M. Lāce (ed.) Valsts Mākslas muzejs. [State Art Museum.] Rīga: Jumava, pp. 335-343.

Lamberga, Dace 2014. Rūdolfs Pērle. Rīga: Neputns.

Latvian Cultural Canon. Available at http://kulturaskanons.lv/en/1/5/42/, last accessed on July 22, 2015.

Latvijas mākslas vēsture. [Latvian Art History.] Available at www.makslasvesture.lv, last accessed on July 22, 2015.

Leerssen, Joep 2006. National Thought in Europe: A Cultural History. Amsterdam: Amsterdam University Press.

Liepiņš, Jānis 1916. Latviešu mākslinieciskais talants. [Latvian Artistic Talent.] Līdums, Oct. 20, No. 241, p. 1. Available at http://periodika.lv/periodika2-viewer/view/ index-dev.html\#panel:pp| issue:/p_001_lids1916n241| article:DIVL13 | issueTy pe:P, last accessed on November 10, 2015.

Lonkila, Helena 2010. Renne Haverinen: From a Guide of the Karelianists to a Mythic Character and Friend. In: M. Vélez Cea \& A. Waenerberg (eds.) Kalevala granaína: Myth, Image, Idea. Ranua: Mäntykustannus, pp. 57-77.

Madernieks, Jūlijs 1914. Ceturtā latviešu mākslinieku izstāde. [The Fourth Exhibition of Latvian Artists]. Latvija, No. 287, pp. 1-2; No. 289, pp. 2-3; No. 295, pp. 2-3; No. 298, pp. 5; No. 301, pp. 2.

Madernieks, Jūlijs 1940. Niklāva Strunkes 25 gadu mākslas izstāde. [The 25th Anniversary Art Exhibition of Niklāvs Strunke.] Jaunākās Ziñas, March 9, No. 57, p. 7. Available at http://www.periodika.lv/periodika2/\#searchResults;si mpleQuery=Nikl\%C4\%81va\%20Strunkes\%2025\%20gadu\%20m\%C4\%81kslas\%20 izst\%C4\%81de, last accessed on July 22, 2015.

Ó Giolláin, Diarmuid 2000. Locating Irish Folklore: Tradition, Modernity, Identity. Cork: University of Cork Press.

Pelše, Stella 2007. History of Latvian Art Theory: Definitions of Art in the Context of the Prevailing Ideas of the Time (1900-1940). Riga: Institute of Art History, Latvian Academy of Art.

R. 1903 = Rozentāls, Janis. Arnolds Beklins. Wehrotajs, Dec. 1, No. 2, pp. 236-243. Available at http://www.periodika.lv/periodika2/\#searchResults;simpleQuery= Arnolds\%20Beklins, last accessed on July 22, 2015.

R. 1904 = Rozentāls, Janis. Adams Alksnis. Wehrotajs, Jan. 1, No. 3, pp. 368-374; Feb. 1, No. 4, pp. 500-505. Available at http://www.periodika.lv/periodika2/\#searchRes ults;simpleQuery=Adams\%20Alksnis, last accessed on July 22, 2015. 
Rūḳe-Draviṇa, Velta \& Tārs, Juris 1989. Blaumanis, Rozentāls un Somija. [Blaumanis, Rozentāls and Finland.] In: V. Rūḳe-Dravina (ed.) Zari. Stockholm: The Baltic Scientific Institute in Scandinavia, pp. 25-73.

Seljamaa, Elo-Hanna 2006. Building Up/On Power: Representations of the Estonian National Character in the Works and Words of Kristjan Raud. Estonian Art, No. 2. Available at http://www.estinst.ee/Ea/heritage/seljamaa.html, last accessed on July 24, 2015.

Šḳilters, Gustavs 1924. Atmiṇas par Rūḳi. [Memories about Rūḳis.] Ilustrēts žurnāls, March 7, No. 10, pp. 216-217; March 14, No. 11, p. 241. Available at http:// www.periodika.lv/periodika2/\#searchResults;simpleQuery=Atmi\%C5\%86as\%20 par\%20R\%C5\%AB\%C4\%B7i, last accessed on July 24, 2015.

Skulme, Uga \& Lapiṇš, A. 1954. Janis Rozentāls. Rīga: Latvijas Valsts izdevniecība.

Šmite, Edvarda 2005. Art Comes into the Lives of the Citizens of Riga. In: M. Lāce (ed.) Valsts Mākslas muzejs. [State Art Museum.] Rīga: Jumava, pp. 328-334.

Šmits, Pēteris 1926. Latviešu mītoloǵija. [Latvian Mythology.] Rīga: Valters un Rapa.

Vīksne, Rudīte \& Stradiṇš, Jānis 1997. Rīgas Latviešu biedrības Zinību komisija Latvijas un Rīgas Kultūrvēsturē. [Scientific Committee of Riga Latvian Society in Cultural History of Latvia and Riga.] Latvijas vēstures institūta žurnāls, No. 3, pp. 103-126.

Zariņš, Rihards 1904. Mahksla un amats. [Art and Craft.] Austrums, No. 1, pp. 65-67, available at http://periodika.lv/periodika2-viewer/view/index-dev. html\#panel:pp| issue:/p_001_aust1904n01| article:DIVL346| issueType:P; No. 2, pp. 147-153, available at http://periodika.lv/periodika2-viewer/view/index-dev. html\#panel:pp | issue:/p_001_aust1904n02 | article:DIVL603 | issueType:P, both last accessed on November 11, 2015. 


\title{
CHILDREN AS PREY: A CASE OF THE UTMOST Contemporary Legends of Organ Theft, Children's Disappearances, Kidnappings, and the Sexual Abuse of Children and Adolescents
}

\section{Véronique Campion-Vincent}

\begin{abstract}
This article discusses several sets of rumours and contemporary legends studied by the author since the 1990s. The common theme concerned with children as prey, victims of ruthless predators, unites narratives of organ theft, the social construction of disappearances and kidnappings, and sexual abuse of children and adolescents. In light of these facts, the denial of yesterday has turned into an ever-growing obsession. This paper examines children as prey through three subthemes, attending to the individual features and to the ways they overlap and also engage contemporary anxieties. An overview of recent events in the United Kingdom and France indicates the persistence of some scary and hazardous hypotheses regarding the children as prey theme.

The concluding remarks are presented in three parts: first, a review of key transformations in the discourse around the children as prey by the adoption of a different approach; second, an in-depth discussion of the well-known tale of the Slaughter of the Innocents, as always present in the successive sets of accusations linked to the emergence of collective faces of the Evil; and third, an analysis of the concept of the utmost, a special type of the extreme. Finally, the author's hypotheses on the contemporary obsession with child sexual abuse are presented.
\end{abstract}

Keywords: children, contemporary legends, moral panics, organ theft narratives, paedophilia, rumours

\section{INTRODUCTION}

This article examines a common theme in several sets of rumours and contemporary legends that I have studied since the 1990s. This theme is concerned with the children as prey, or the framing of children as victims of the malevolence of ruthless predators. As I will explain below, this theme is not directly expressed but rather presents itself as a conclusion one arrives at 'naturally', by taking into account a biased and hyperbolic presentation of evil, manifested at the 
very core of these rumours and contemporary legends. Following this logic, the children as prey unifies diverse figurations of evil. I also treat disappearances and kidnappings, and the sexual abuse of children and adolescents as facts that are socially constructed and manipulated through narratives. Such an approach allows me to discuss the radical change of attitudes that has also produced a major shift in the children as prey theme, and to suggest that these transformations require further study.

Following the chronological sequence of my previous research, I will first present organ theft legends in which presumed victims were children (CampionVincent 1990, 1997, 2005).

I will then discuss attitudes concerning disappearances and kidnappings, which have evolved from denial to obsession, followed by sexual abuses against children and adolescents (Campion-Vincent 2004, 2006, 2008). Although treated separately in this paper, the three themes overlap and also engage contemporary anxieties.

The children as prey theme is a case of the usage of the utmost, a rhetorical device of persuasion developed through hyperbole and extreme oppositions. Invoking the utmost can render what is exceptional - in this case, manifestations of the extreme evil - as commonplace events.

\section{ORGAN THEFT}

Accusations of systemic organ theft by organised networks appeared in Latin America around the end of the 1980 s, with the development of organ transplantation, following improvements in the control of rejection problems. Leaving aside the stolen kidney motifs that appeared and continue to flourish in wealthy nations and that focus primarily on adults, my discussion will focus on the representation of organ theft in the narratives that I call baby parts and eye thieves.

Baby parts narratives assert that the international adoption of children from poor and developing nations is characterised not only by irregular practices, but also by criminal ones. The babies adopted from abroad did not arrive in the homes of loving families but instead were sent to operating theatres where they were cut into parts by unscrupulous surgeons for patrons from rich countries.

In 1987, there were incidents in Central America (Honduras, Guatemala) in which the discovery of babies who had been kidnapped in order to be sold for adoption abroad was interpreted as proof of organised organ theft. Articles in the local press then picked up the accusations against 'the organ mafia' which circulated orally. These views regarding organised organ theft were 
endorsed by pro-Communist and pro-Third World press all over the world. Through the vigorous propaganda activity of the U.S. Information Agency and other U.S. agencies, several denials countered these accusations. However, on September 15, 1988, following an initiative from a French representative, Danielle de March, affiliated with the Communist Party, the European Parliament adopted an accusatory motion expressing condemnation of the trafficking of organs of Third World babies, which specifically referenced the incidents in Honduras and Guatemala, and identified Israel and the United States as complicit nations. The United States responded on July 15, 1989, with an official letter of protest that suppressed the publicly supported accusations.

In 1992, similar accusations regarding the diversion of international adoption surfaced in Russia and East European countries where international adoption had grown after the fall of the Iron Curtain.

The eye thieves narratives that appeared around the same time, in Central America but also in the Andean Region, Argentina and Brazil, relate the discovery of a mutilated body of a street child along with some money (a larger or smaller sum) and a hand-written note: "Thank you for the/your eyes (or kidney)". The murders of street children, often involving mutilation, reinforce the terror that the elimination of those deemed "disposable/discardable" intends to convey, and also appears to validate accusations of organised organ theft and the complicity of the state. For example, the fact that such murders often remain unpunished suggests that they are perpetrated with the complicity of authorities (police and militias hired by shopkeepers harassed and robbed by the street children), and the fact that the murders are executed semi-clandestinely reinforces uncertainty about their origin and nature.

Another motive in eye thieves narratives can also be found in the accusations targeting clinics and hospitals that allegedly kill or mutilate their patients in order to sustain a system of organ trafficking for the benefit of rich nations and individuals. In fact, a specific form of trafficking has existed for corneas - which are tissues and not organs and can thus be easily harvested after death - in mortuaries around unclaimed bodies.

Consider, for example, the accusations, followed by denials, in the case of the young Columbian Jeison, who, according to his parents, lost his sight because of the hospital's criminal activities. This case became a public controversy in France as a result of Marie-Monique Robin's movie Voleurs d'yeux (Eye Thieves, 1994), the (disputed) recipient of the 1995 Albert Londres Prize for journalism.

Widespread perceptions of the dangers posed to children by predatory foreigners did not diminish in Latin America: cases in point include the 1994 lynching in Guatemala of a U.S. citizen from Alaska, and another in 2000 (a Japanese national), and in Peru at the end of the 1980s of a Swiss citizen, 
which was followed by an urban unrest. These events have been detailed in various studies (Ansión 1989; Molinié Fioravanti 1991), which have also pointed to persistent tensions. The incidents in Guatemala originated with tourists taking pictures - acts that were interpreted by locals as preparing kidnappings of children for organ thefts.

Today there are no more public accusations of the kind. However, distrust of the abuses that international adoption might generate has led to an important diminution of the practice. Opinions are split as to the accusations. On the one hand, all elites and reasonable people deny the existence of organised networks of organ theft. There are numerous impossibilities, of which the most glaring is the multiplicity of actors in organ transplant surgeries, making secrecy impossible. There is also an abundance of organs for sale: why bother to steal organs you can buy? On the other hand, a massive fictional production is entirely oriented towards the validation of these allegations of the organised networks of organ theft. Furthermore, belief in the existence of these networks remains entrenched in the public opinion. There are two main reasons for this: first, the pessimistic conviction that in contemporary society "anything is possible"; second, a confusion with authentic scandals caused periodically by the persisting international organ trafficking.

Today organ theft accusations have declined. In 2014 they were still present among the accusations surrounding the ill treatment of prisoners in the Kosovo War, yet with no real consequences.

Organ theft accusations are often mentioned by sensationalist media to explain away a mysterious disappearance. A recent example occurred in the Netherlands in June 2014, when the news site www.ad.nl published a sensational story about two Dutch women who had disappeared in Panama, asserting that 'local sources' had revealed that they had fallen victim to an organ theft ring. Peter Burger, a specialist of contemporary legends, reacted, pointing out the story's many errors on his website (Burger 2014a), and the news site retracted the item (P. Burger, personal communication, June 12, 2014).

\section{FROM DENIAL TO OBSESSION}

The two subjects - disappearances and kidnappings, and child sexual abuse that I will discuss further down, have generated many legends, but it is important to remember that their origin lies in a radical change of attitudes towards recurrent facts. Previously these facts were not only ignored, but also explicitly denied; today they are recognised and have become obsessive focal points. This obsession seems to validate several breaches of the rule of law: 
The rise or disappearance of former prohibitions is always compensated by the resurgence or reinforcement of other taboos. As if society tried to get off lightly and ease its conscience. [...] The field of sexual delinquency implying minors is especially appropriate to this exercise. The legitimate and consensual emotion that invades us when suspecting sexual abuse troubles judgment: fantasy dominates, psychology regresses, and the Law abdicates. (Bensussan \& Rault 2002: 264) ${ }^{1}$

The emergence of major concerns about child sexual abuse in the United States during the early 1980s marked a radical transformation in social attitudes and stood in total opposition with more indulgent views that prevailed in the 1950s and 1960s (Jenkins 1998: 83-90).

This shift falls into the analytical domain of those studying the surge of social problems; here, the approach of constructivists - marked by the pioneer book published by Malcolm Spector and John Kitsuse in 1987 - has been decisive. Constructivists underlined the importance of the assertions of claims-makers in the evaluation of tense situations and remarked that the latter ignored the socio-economic constraints that played an important role in these situations; they aimed to transform these tense situations into social problems that could be solved through mobilisation alone (Spector \& Kitsuse 1987; Best 2002).

\section{DISAPPEARANCES AND KIDNAPPINGS}

The white slave trade kidnapping narratives will not be discussed here as these kidnappings - erroneously presented as the main source of prostitution - do not target children.

\section{Missing Children}

The missing children movement surged in the United States in the mid-1980s, amidst the unrest that resulted from a series of disappearances of which the best known is that of Ethan Patz (6 years old) in New-York on May 25, 1979, on his way to school ( 2 blocks). Ethan was never found but has been immortalised by the movement. Many countries, including France since 2003, mark May 25 as the Missing Children's Day, which was established in the United States in 1983.

The 6-year-old Adam Walsh disappeared on July 27, 1981, from a Sears department store in Florida and two weeks later his body (actually only the severed head, in a drain pipe) was found 62 miles from the place of his disappearance. His father, John Walsh, became a tireless activist whose deposition 
at the Senate has remained notorious for its exaggerations. In 1983, the TV movie Adam overwhelmed the United States. From 1988 to 2011 John Walsh hosted the television programme America's Most Wanted, whose website announced proudly its 1000th capture on May 2, 2008. In 2008 John Walsh opened the National Museum of Crime \& Punishment in Washington D.C., on 28,000 square feet $\left(2,600 \mathrm{~m}^{2}\right)$. In 1994, the National Center for Missing and Exploited Children (NCMEC, co-founded by John Walsh in 1984), launched - in collaboration with the U.S. retail giant WalMart - the programme called Code Adam. This programme developed a standard set of instructions to be followed by employees in the case of a missing child in a department store or a shopping mall, and it still stands as current protocol.

Named after another victim (9-year-old Amber Hagerman, 1996, Texas), Amber Alert is another child abduction alert system, one that specifically aims to mobilise and coordinate the media and authorities. It was adopted in France in 2006 .

The first names of other girls kidnapped and murdered by recidivists - the 12-year-old Polly Klaas (October 1993, California) and the 7-year-old Megan Kanka (July 1994, New Jersey) - are emblems standing for the repressive measures taken to control sex offenders having served their sentences. Thus long-missing children are remembered in the 21 st century through their association with these repressive measures that still persist.

An important polemic - still active thirty years later - began in the 1980s and focused on the accuracy of statistics concerning missing children. In 1982-1984 the figures were inflated beyond reason and "Senate and House committees were told that as many as 'two million children' disappeared each year and as many as 'five thousand were murdered through kidnapping and abduction"' (Fass 1997: 243).

Criticised already in 1985, these wild statistics were put to rest in 1990 by the pioneering and comprehensive statistical study of the problem of missing children, "National Incidence Studies of Missing, Abducted, Runaway, and Thrownaway Children" (NISMART), a study conducted jointly by the NCMEC and the U.S. Department of Justice. Two-thirds of the cases were related to runaways and thrownaways, family abductions being the next:

Among non-family abductions, NISMART has identified 3,200 to 4,600 child abductions / kidnappings per year. [---] In the NISMART study, the more restricted category, "stereotypical kidnapping," included only the most serious cases of longer detention or intentional abduction, and those in which the child was gone overnight, killed, or transported fifty miles or more, or there was evidence of intent to keep the child permanently. 
These cases [---] were comparatively rare, and in 1988 probably numbered between 200 and 300. [---] Finally, of the stereotypical stranger abductions, the report estimated that between 43 and 147 children had been murdered as a result. (Fass 1997: 243-244)

Comparable figures were quoted in the 2000s. But, as Paula Fass remarks:

The figures only seem small when compared to the initial inflation used to fan the campaign in the 1980s. [---] If the children disappear forever, as many of them do, if they lose their identities, their past, or their lives (and probably half fall into this last category), then the cumulative numbers over a decade become a terrible chart of social and personal loss. (Fass 1997: 254)

\section{Disappearances and Kidnappings in France}

At first, French institutions resisted the anguished claims coming from the United States. Towards the end of the 1980s, authorities refused to answer the requests of activists who tried to define, as major social problems, the disappearances and kidnappings of adults, about which the law was rather vague, and especially of children. It took, among other factors, several scandals for the attitudes to change for good in the 1990s, when disappearances and kidnappings became acknowledged facts: first, the Mourmelon disappearances of young soldiers - long denied by military authorities - that have remained mostly unsolved; second, judicial indifference in the case of the missing girls in care in the city of Auxerre, causing the long-term impunity of the serial murderer Émile Louis; third, the discovery of the long unpunished sexual murders of Michel Fourniret, who acted with his wife's active complicity (each of these serial murderers killed several victims under 15 years of age).

The first disappearance in France that generated an important mobilisation was that of Marion Wagon, on November 14, 1996. Six years later, that of Estelle Mouzin, also 9 years old, on January 9, 2000, led to a national mobilisation and the creation of a very active association. Both cases remained unsolved. Lacking concrete means of action, these mass mobilisations enacted symbolic gestures: white marches, balloons releases, etc., staging outraged innocence. 


\section{The Attempted Abduction}

In 1996, the legend of the attempted abduction, which had spread in the United States since 1978, began to circulate in France. A study authored by Mireille Donadini-Rousseau documented the circulation of this legend in the south of France (Donadini-Rousseau 1998). From a different source, a typical version, told by a person who claimed to have been a direct witness, is quoted here:

Mlle Gisèle Gourdon, [twenty-five, has two degrees and is working for her PhD in England] [---] had spent Christmas at her home in Fayence, Provence, and there she had heard a similar story from her mother, a village housewife of about fifty. [---]

"I [the mother] went to Mme Iehl to get the story of the kidnapped child. It's a true story, not a myth, and often happens in superstores, where security depends on closing off the exits immediately, because attempts at kidnapping take place very quickly without anyone being aware.

On 16 December 1996, Mme Iehl went to Nice Airport to buy tickets for her grandson, and then went shopping at Cap 3000 [a shopping mall] at St Laurent du Var, which is where it happened! A mother who had put down her purchases at the checkout noticed that she'd forgotten butter, and sent her little daughter back to get it, a child aged seven. Scarcely five minutes later, as the little girl hadn't come back, she became worried and reported it. The checkout girl gave the alarm, and all the exits were immediately closed. After a search, the little girl was found asleep in a changing-room, but with her hair cut short and wearing different clothes. The child was all ready to be taken away, but since the exits were closed faster than they had anticipated, the kidnappers didn't finish their work. It is not only in France that these kidnappings occur. [---]

Contacted by telephone, the security staff at Cap 3000 said there had been no such incident and they had never heard the story. (Roper 1997)

This narrative features an attempted kidnapping in a public setting where adults and children mingle - amusement park, shopping mall, department store - and generally ends well, since the child is found. But the story contains some grey areas: the failed kidnappers remain unidentified and are thus still free to strike again; also, the reasons for the attempted abduction remain unknown. The Code Adam protocol presented earlier is said to be applied so that once the alert is sent, the employees close the doors and start a general search that concludes in the recovery, in public toilets or in a fitting cabin, of the child who has been disguised or drugged and whose hair has been dyed or shaven, two very improbable elements as remarks a lawyer quoted by Jan Brunvand: 
"How do you manage to dye a kid's hair in public toilets? I'd rather give a bath to a cat" (Brunvand 1986: 150).

Another consequence of this atmosphere of anxiety is the recurrent circulation of "Wanted" notices on the Internet and social networks. These notices most often concern imaginary children or children already found and thus add to uncertainties surrounding disappearances.

\section{Situation in France in 2014}

In 2014, the situation in France was the result of an evolution that had started in early 1995, with the enactment of a law concerning the search for missing persons (Journal Officiel 1995: 1249).

This law was followed, in 2002, by the creation of the Office Central chargé des Disparitions Inquiétantes de Personnes (Central Office in Charge of Alarming Disappearances, OCDIP) (May 3, 2002), a centralising body requested by the militants. The existence of the OCDIP brought new importance to the development of statistics, as new measures adopted in September improved the law of 1995. However, in 2006, the Office Central pour la Répression des Violences aux Personnes (Central Office for the Repression of Violences towards Persons, OCRVP) integrated the missions of the OCDIP and of the National Division to counter attacks on individual persons.

In the long brief detailing of the new structure's multiple missions, the paragraph concerning alarming disappearances (all minors' disappearances are classified as alarming) seems lost amongst other missions that include the protection of victims of sectarian abuse:

The Office is also competent to investigate cases of:

Majors and minors disappeared in alarming conditions, whatever the cause of the disappearance. These investigations are conducted in accordance with the procedure considered in article 26 of the law of January 21, 1995, or in the frame of a criminal inquiry;

Discoveries of unidentified bodies;

Sectarian drifts creating penal infractions. ${ }^{2}$

Since 2006, the official statistics on alarming disappearances of minors, around 1,000 per year, are no longer accessible to the public. The American Kidnapping Alert (Amber Alert) model, adopted in 2006, was used ten times in 2013. Each time with success, but two per year is a drop of water in the ocean of disappearances (1,000 per year). A new federative association, 116000 Enfants Disparus, ${ }^{3}$ manages the European hotline for missing children, 116 000. It maintains a Facebook page and publishes annual reports. 


\section{CHILD (SEXUAL) ABUSE}

A seminal article published in 1962 by paediatrician C. Henry Kempe (Kempe et al. 1962) was a major factor in discovering the frequency of ill-treatment of very young children by their close kin. The study brought about a focus on intrafamilial abuses, including sexual abuse. Kempe campaigned successfully for the adoption of abuse reporting laws that made it mandatory for social workers or teachers to report situations of abuse to authorities. In 1972, Kempe created the National Center for the Prevention and Treatment of Child Abuse and Neglect, and in 1977 the International Society for the Prevention of Child Abuse and Neglect (ISPCAN), which fostered an international multidisciplinary journal, Child Abuse and Neglect.

The proper term is probably rediscovery as abuse in families was a subject of debate in the 19th century, as a consequence of the development of public hospitals. The subject was launched in France by Ambroise Tardieu's pioneering works, a book in 1857 and a lengthy article in 1860 (Tardieu 1857, 1860). Tardieu was rediscovered in the 1960s and the battered child syndrome is also called Tardieu's syndrome.

Since the 1970 s, a radical and nervous climate thus developed around children, and especially around the notion of the child as victim of sexual abuse by adults considered as absolute evil. A true moral panic seems to have seized the whole of society.

\section{Situation in France}

In France sexual abuse against children emerged as a subject of public concern in the late 1980s as witnessed by the growth of sentences for rapes of children (the judicial expression is "minors under 15 years of age"), multiplied by six from 1984 (100 per year) to 1993 (578). In 2000, the figures were close to those of $1993-599$ sentences.

In 1988, the French Department of Social Affairs organised its first public campaign against the sexual abuse of children. An abuse reporting law was adopted in 1989 and allegations and incidents of abuse needed to be reported to a local administrative body (the district's Conseil Général), which would then decide whether to implement measures to help the family or refer the case to a court. This 1989 law also established the lengthening of the limitation period for incest to ten years beyond the victim's majority. In 1993, a reform of the Penal Code confirmed the recognition of sexual abuse through a radical redefinition and renaming of "offenses to public morale" as "sexual aggressions". Very 
heavy sentences, up to 20 years of prison time, were then enforced, making France one of the most repressive of European countries.

In the 21st century France, the paedophile is the monster and a criminal who represents absolute evil. From Lille to Marseilles terrifying tales (mostly erroneous) of aggressions and kidnappings circulate, peppered with a zest of organ theft. Their examination shows that the themes of organ theft and kidnappings remain very close to the fear of paedophilia. Practically every week police forces are alerted about a sexual aggression against a child or a kidnapping that is generally revealed to be false. Some have caused very serious incidents (see the list in the appendix (Aron \& Cognard 2014: 126-138) concerning cases that took place in France in 2010-2011 and entailed police inquiries).

\section{Conspiracy of the Elites}

In the discourse of child sexual abuse, a prominent structural feature is the conspiracy of the elites, based on the assumption that child abusers generally belong to privileged social classes and are thus embedded in powerful and protective networks that enable them not only to obtain their prey but that also help them to hide their crimes.

This theme has been prominent in three cases that received significant media coverage in France.

Firstly, the case of Marc Dutroux from Belgium, who was perpetrator of several kidnappings and murders, which were discovered in 1996 and resulted in the sentencing of Dutroux and his wife in 2004. During the lengthy judicial inquiry, Dutroux had repeatedly asserted that he was "working for a network", and several media, even the parents of one of his victims believed this was the case. Furthermore, a whole array of sensationalist media fell for the extravagant accusations of Régina Louf, who maintained that she had seen the King of the Belgians participate in horse-riding child hunts where the hunters were equipped with bows and arrows in a walled-up secret park. Louf (who had certainly been a victim of abuse) was no longer considered a witness by justice after 1997 but several 'documentaries' uncritically spread her wild accusations.

Secondly, the case involving the city government of Toulouse (sadism and murder accusations orchestrated against the Mayor Dominique Baudis, who in 2003-2005 was accused of having ordered murders from a murderer Patrice Allègre, convicted in 2002. The accusations were picked up in the media: thus the reference daily Le Monde, dated June 17, 2003, published a sensational "Affaire Allègre: Les enquêteurs reconstituent l'histoire de la maison de Noé" (Allègre Case: Investigators reconstruct the story of the Noe's house), filled with 
juicy details describing the hypothetic place of the supposed orgies and "red masses with animal sacrifices". But Le Monde apologised in September and the author of the article publicly admitted that he had been repeating hearsay.

Thirdly, the case of Outreau (intrafamilial rapes transformed with the active participation of convinced therapists into a supposed case of paedophile sex networks, which entailed numerous arrests in 2001-2005). Those arrested for participation in a sex network were freed and compensated after being exonerated by the second trial in 2005, with the exception of the parents and another couple of neighbours. However, in 2013, eight years after the second trial, participants of the 'sex network' version are still very present. This topic will be taken up later.

\section{Satanism Scare}

It was in the late 1980s that accusations of satanic ritual abuse became topical in the United States. The Satanism Scare (Richardson \& Best \& Bromley 1991) was a complex phenomenon influenced by the beliefs and actions of many different actors: religious fundamentalists, psychiatrists, and psychologists engaging in an uncritical use of hypnotic regression techniques that often created false memories, as well as feminists for whom these supposed horrors exemplified masculine tyranny. The accusations also relied on inflated statistics of disappearances erroneously quoted by the missing children movement to legitimate the extreme assertions made in The Satanism Scare that missing children were often sacrificed during cannibalistic ritual orgies. The supposed link of Satanism with disappearances seemed to give weight to assertions that are discredited today but still believed in certain circles that continue to practice uncontrolled hypnotic regression techniques.

Jean La Fontaine, an anthropologist in charge of an official inquiry on satanic ritual abuse accusations that impacted social services personnel in Great Britain through biased seminars given by their U.S. counterparts, analysed the survival of discredited beliefs:

This contemporary social movement has evolved, relying after 1995 no longer on children's assertions but on adult "survivors" as patients rather than saved souls. The movement drew on different strata of British society: In the first phase "Christian fundamentalist fighting against the occult, feminists and social workers who had been convinced there was a new threat to children [...], professionals in the psychotherapeutic community supported by certain feminist activists" in the second phase. (La Fontaine 1998: 160) 
While in France the satanic ritual abuse movement only spread to limited circles of evangelist Christians, many French professionals, psychotherapists, feminists, and activists took up the idea that "the acceptance of the stories of the victims as true, even or perhaps especially when they seem incredible, is a demonstration of support and may be experienced by the teller as healing" (ibid.: 6). The origins of the French Outreau case, which led to the erroneous indictment of many innocent persons who were accused of active participation in imaginary sex networks (see above) are evident in this quotation.

\section{Repressed Memories of Sexual Abuse}

In the late 1980s several American psychotherapists and psychiatrists adopted the theory that memories of traumas - and especially of sexual abuse during childhood - were often repressed and that the recovery and rebuilding of these lost memories through hypnosis was a miraculous remedy for 'survivors' who had previously been mistreated by their parents. Accompanying this theory was the notions, that survivors often developed multiple personalities - 'alters', whose manipulation and evocation by the therapist could induce the cure. In addition, some believed that abusive parents were often active members of satanic cults (see the earlier discussion).

The Courage to Heal: A Guide for Women Survivors of Child Sexual Abuse by Ellen Bass, a poet and creative writing teacher, and Laura Davis, an incest survivor, was an international bestseller with four editions from 1988 until 2008. It became the bible of the movement. Bass and Davis had no training in psychotherapy and "defended their lack of training, saying that a $\mathrm{PhD}$ is not necessary 'to listen carefully and compassionately to another human being". Their approach was simple, even simplistic: any disturbance or social maladjustment was the consequence of sexual family abuse, suffered in early childhood, repressed and forgotten. These memories could be recovered through hypnotic psychotherapy leading to cure. They thus defended "the vision that childhood sexual abuse could be discovered with no corroborating evidence beyond a vague set of symptoms". ${ }^{4}$

The theory was applied with messianic zeal. Utilising hypnosis, dream analysis, guided imagery, and regression towards previous ages, the convinced therapists persuaded their patients, mostly women, to 'recover' from the sexual abuses that marked their childhood, generally abuses perpetrated by their fathers or step-fathers, sometimes with the active participation of their mothers. More-over, many of these patients became convinced that they had developed multiple personalities and the orientation of their therapy in that direction aggravated their condition: 
Disintegrating even more, these unfortunate were then sent in costly clinics specializing in "dissociated identities" where their fantasies to harbour five, a dozen or up to hundreds of alternative identities were flattered until, their insurance policy being over, they were abandoned in a lunatic state. At the top of the panic, some traumatologists considered that "from twenty to fifty per cent of psychiatric patients suffer from dissociative disorders". (Crews 2004; quotation Van der Kolk \& Van der Hart 1991: 432)

The attacks led by psychologists and psychiatrists that did not subscribe to the theory of repressed memory were decisive and effectively discredited the allegations of the survivors who had recovered their memories through hypnosis, as well as the depositions of children obtained through suggestion. A seminal book to turn the tide was published in 1994 (Loftus \& Ketcham 1994).

While professionals were anxious to maintain "the recognition and treatment of sexually abused children" (Brandon et al. 1998: 296), they realised the danger of resorting to methods that created fictions and distanced themselves from them, specifying, for example, that "when memories are 'recovered' after long periods of amnesia, particularly when extraordinary means were used to secure the recovery of memory, there is a high probability that the memories are false" (ibid.).

\section{Abuse by Strangers, Sexual Predators}

It has been shown earlier that alarming kidnappings by strangers constituted only a small percentage of disappearances of minors. However, public attention has focused on these relatively rare cases. The irrational violence of evil characters striking at random victims raises emotions and these horrors seem easier to solve radically than the more complex cases of violence within the family, which occur frequently in socially deprived groups. These more numerous cases are neglected, do not become 'good' subjects for large-scale media, and do not generate urban legends. The media and human interest stories that attain a legendary status centre on white children of the middle classes who inspire dramatic tales and vigilante-oriented action. According to the logic of these tales, the problem does not concern social organisation, and society in general does not incur any responsibility since it is the work of evil individuals. Proposed solutions tend to advance this theory of the problem's origin: a better implementation of law, more severe sentences of imprisonment, and enlargement of prisons rather than development of social programmes (Conrad 1998).

At the beginning of the 1990s an extreme view on child abusers became prevalent in the United States. They became considered as potential recidivists 
beyond redemption. The expression 'sexual predator', already used in sensationalist crime fiction, did not reach the press until 1987, and was still infrequent in 1987-1989, but it appeared 140 times per year in 1990-1992, 321 times in 1993, 865 times in 1994, and 924 times in 1995 (Jenkins 1998: 189-214).

In 2007, the official website of the U.S. Immigration and Customs Enforcement launched Operation Predator, still active in 2014 and self-defined as "an ongoing enforcement effort targeting those who prey upon and sexually exploit our nation's children - including Internet pornographers, international sex tourists, and foreign national sexual predators". ${ }^{5}$

Moreover, as Philip Jenkins notes, it is commonly asserted that sex abusers have invaded cyberspace, which has thus become terribly dangerous. This surge of fear exemplifies the adaptation of the fears of sexual abuse of children to new environments (Jenkins 1998).

In 2014, specialised police units hunted down 'cyber-predators' in France by infiltrating meeting sites that connect to young female adolescents. Early in 2014, Terre des hommes Netherlands, a Dutch branch of the Swiss organisation Terre des hommes (Land of Men) based in The Hague, announced proudly to have invented a 'bait-child' called Sweetie, and thus to have succeeded in tracking numerous predators. The picture, meant to terrify, shown on the organisation's Facebook page, is worth reproducing.

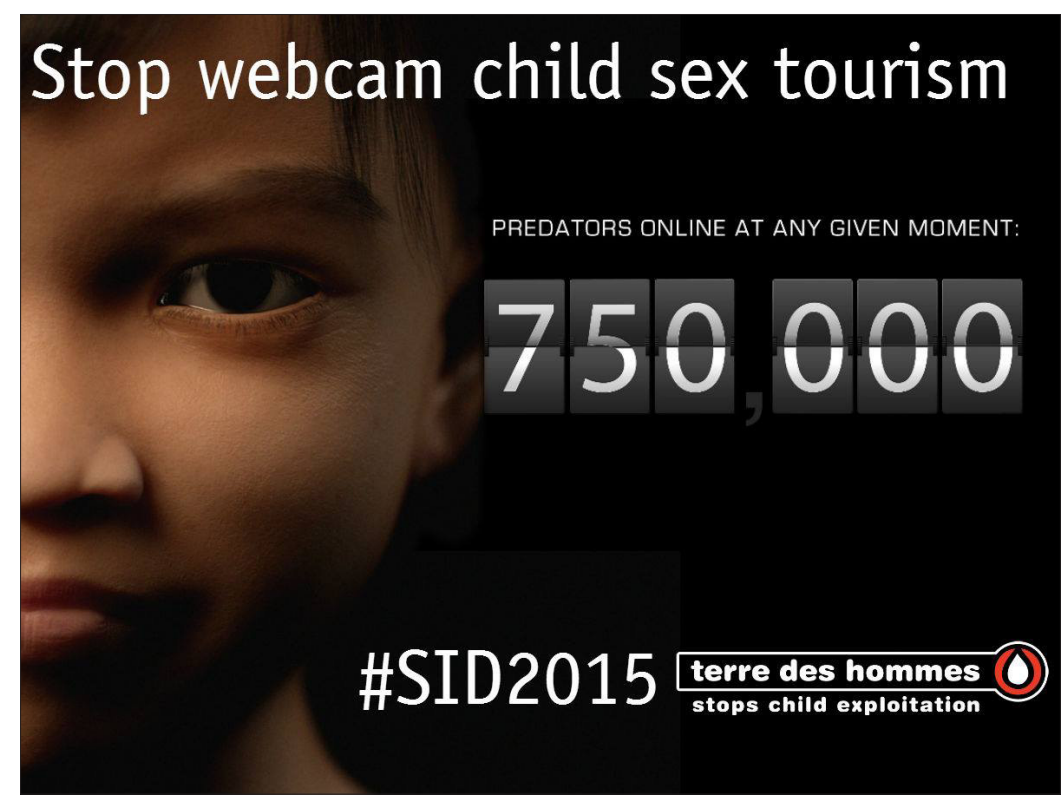

Figure 1. https: / / www.facebook.com / Sweetie.International / photos / a. 80436180 9576476.1073741828.803980692947921 / 930457996966856 / ?type=3\& theater, last accessed on November 17, 2015. 


\section{Hunting Down Potential Recidivists}

In the United States the programmes for the prevention of sexual abuse delivered in schools since the 1980s shifted in the 1990s, to focus on dangers caused by chance encounters, 'stranger danger'. Murders by recidivists of young victims met by chance have had a huge impact and have led to the adoption, strongly encouraged at the federal level, of laws and administrative measures planning mandatory treatments (behavioural, psychiatric, and chemical), police surveillance, and reporting to local communities, for those who have been sentenced for child sexual abuse and have completed their imprisonment. At the level of each state, information is increasingly being shared: records (including names) of those who have been formerly sentenced, the motives of their sentences, their descriptions and addresses are compiled and published by the authorities. Jenkins notes that in 1998 the records made public by the State of California contained the names of 64,000 liberated sexual abusers (Jenkins 1998: 189-214).

As anticipated, these measures consequently led to numerous attacks against those who had been convicted and then released. The reporting practices were contested by certain lawyers and magistrates as they effectively constituted informal extensions of prison sentences; however, they were still followed in 2014. One of the recent measures is the Adam Walsh Child Protection and Safety Act (July 27, 2006), which imposes strict controls on those deemed the most dangerous sexual abuse offenders, including the requirement that they declare their residence to authorities every three months, and paves the way for an integrated reporting and surveillance system at both local and federal levels. In March 2007, nineteen U.S. states maintained retention centres for sex offenders who had completed their sentences, and other such centres were planned, especially in the State of New York. The results of these treatment centres, which handled 2,900 sex offenders who had completed their sentences, seem disappointing and very difficult to evaluate. Furthermore, one must take into account the fact that there are few professionals receiving recognition from their peers, among those who have received lucrative contracts to implement the treatment programmes (Davey \& Goodnough 2007a, 2007b, 2007c).

\section{CHILDREN AS PREY IN 2014}

\section{The United Kingdom}

In the United Kingdom, the posthumous revelation of numerous sexual abuses perpetrated by Jimmy Savile (1926-2011), a TV and charity fundraiser per- 
sonality, created a scandal. It developed into an investigation of past sexual abuses carried out by other living media celebrities, which was not devoid of hysteria, hype, and fabrication. In general, there was little protest regarding the allegations and sensational media coverage.

Launched in October 2012, after the screening of Exposure: The Other Side of Jimmy Savile, an ITV documentary that denounced Savile's many abuses, Operation Yewtree, an inquiry headed by the Metropolitan Police, examined the numerous allegations that circulated after Exposure. Published January 11, 2013, the report, Giving Victims a Voice, ${ }^{6}$ was co-written by the Metropolitan Police and the National Society for the Prevention of Cruelty to Children (NSPCC). It disclosed the inquiries concerning Savile, including 450 allegations and 284 criminal offences, but also revealed other inquiries into sexual abuses by living persons, which involved prosecutions. Operation Yewtree was justified in the introduction as follows:

Savile was able, through his celebrity status, to 'hide in plain sight' while abusing children and adults over six decades [---] We must use the learning from these shocking events to prevent other children and vulnerable adults being abused in the future. They will get a voice. (Gray \& Watt 2013)

The critics, infrequent and marginal, raised interesting points: What was the point of "putting the past on trial" (Hume 2013)? Was it the police's mission to ask "anybody who claims to have been abused by a public figure in the distant past to come forward" (ibid.)?

The idea of conspiracies to abuse children, though unofficial, had not disappeared, remarked Jean La Fontaine, and, as the Satanic explanations were discredited, had become "non-religious in appearance but no less zealous and demonological in essence" (Black 2013). The deep unity between "the Satanic panic of the early 1990s and the post-Savile celebrity witch-hunt of today" was "the near existential need among certain sections of society for the existence of evil" (ibid.). La Fontaine had remarked in her 1998 book that today the sexual abuse of children was the most potent representation of evil.

Frank Furedi stressed the mix of reality and entertainment in Operation Yewtree, especially regarding the public response to its revelations. Recalling the TV series, To Catch a Predator, launched in the United States in November 2004, in which investigators impersonated youngsters to bait 'predators', leading to arrests on camera where "potential sex predators were put in the spotlight in order that they might be humiliated and punished for their behaviour" with the active participation of the police, Furedi concluded that "sometimes it seems that even the people involved in official inquiries into alleged past behavior also struggle to distinguish between media reality and reality itself" (Furedi 
2013b). Furedi authored a book on the subject (Furedi 2013a) that received a very severe review in The Guardian, which judged it as insensitive and short-sighted, saying: "[Furedi] sidesteps the 'victims' completely. He shows no interest in them, Savile or the culture in which this abuse was prevalent" (Moore 2013). A more measured review in the Times Higher Education was also unfavourable, arguing that Furedi was too narrowly focused on the denunciation of moral crusades to treat fully the questions raised by the treatment of the Jimmy Savile case (Egan 2013).

These criticisms are marginalised in the British media, even if one article written by academics takes the same approach and mentions moral panics (Cree \& Clapton \& Smith 2014).

\section{France}

Controversy over the Outreau case (see above) that developed from 2001 until 2005 , is still alive today, with a minority defending the notion that there really was a sex network, although the second trial of 2005 dismissed the idea when only the abusive parents and another couple were sentenced, and the other adults supposedly involved in the 'sex network' were freed and compensated. In February 2013, accusations surrounding the case took the form of a film that was released in theatres. The screenplay was written by Serge Garde, a retired journalist who had belonged to the communist daily L'Humanité and had formerly co-authored with Laurence Beneux, journalist in the conservative daily Le Figaro, a book that fully endorsed sex network hypotheses in paedophilia cases (Beneux \& Garde 2001). Interviewed at length in the movie, psychologist Marie-Christine Gryson-Dejehansart, whose partisan expertise had been severely criticised during the Outreau second trial of 2005, continued to defend the exclusive truth of "la parole de l'enfant" (the child's word) (Gryson-Dejehansart 2009). Chérif Delay, the main victim of repeated rapes perpetrated by his own parents and now an adult, was also interviewed. Delay had co-written a book with Serge Garde, describing his terrible experience but also defending the sex network hypothesis (Delay \& Garde 2011). Delay toured the conference circuit with journalist Jacques Thomet (Thomet 2013) to defend their theory of a paedophile network. While the hypothesis of a criminal conspiracy is invoked in the Outreau case, it is not a conspiracy of the elites since the parties do not belong to the elite classes.

Reworking several unsolved cases of disappearances, the sensationalist journalist Karl Zéro's recent book presentation resumes the 'networks' theme: 
Where is Maddie McCann, the 4-year-old little English girl who disappeared in Portugal? Who kidnapped Estelle Mouzin? [---] Karl Zéro has reworked all these cases, one by one. [---] This book sheds a new light on these files of unsolved disappearances. It reveals the dysfunctions of the law and the existence of networks that some obstinately deny. (Zéro 2014)

These themes and cases are echoed on the website Égalité et Réconciliation (Equality and Reconciliation), created by influential populist Alain Soral. ${ }^{7}$ Soral produced 55,900 YouTube videos in 2014 and 5,200 of these (almost 10\%) concern paedophilia envisioned as a characteristic of the 'new' Zionist elites he opposes. Jacques Thomet's book has been published by Kontre Kulture, Alain Soral's publishing house.

What we see here is a case of instrumentalisation, where child sexual abuse cases are assimilated into a conspiracy of the elites, of which they constitute an especially horrible occurrence, situated in the realm of propaganda and not that of legend. An analysis of the exploitation of these themes in extremist fringes of society is beyond the scope of this paper; however, the assertions of the extremists are important as they are a powerful conduit of legends.

The situation is very different in the United Kingdom and France. In the former, people contesting the network hypotheses are on the margins, in the latter it is those who defend the legitimacy of the networks that are marginalised. But an in-depth study would certainly show that the approaches in the public are more complex than they seem to be in these two countries. These hypotheses are not situated in the realm of rational analysis. Adhesion to them is fleeting and the idea that terrible crimes are committed according to some master plan can be harboured, albeit often briefly, by each of us, especially when we discover a new horror through the media.

After investigating the emergence of legends in the three different domains of (1) organ theft, (2) the reinterpretation of disappearances and kidnappings, and (3) new approaches to child abuse and child sexual abuse, it is important to recall that, although they had to be discussed separately, these issues are all linked to the defence of children. This convergence over the defence of children resonates in the various panics and reactions in which they can also be found.

\section{CONCLUSION}

Concluding remarks will unfold in three parts: firstly, a review of the transformations in the discourse of children as prey, as brought about by the adoption of a different approach; secondly, an in-depth discussion of the tale of the 
Slaughter of the Innocents, as an always present sub-text in successive sets of accusations that involve the emergence of collective faces of Evil; and thirdly, an analysis of the concept of the utmost, a special type of the extreme.

\section{A New Approach Transforms the Phenomenon}

When it comes to ill-treatment, disappearances, and sexual abuses targeting children, what weight should be given to the increasing number of statistics compiled to approach these social problems? In his book on statistical illusions, Joel Best builds on his previous studies (Best 1987, 1990) about missing children in his review of well-known facts. A social problem supposes certain definitions - variations of these definitions can radically modify perceptions of the problem. Thus, most cases of ill-treatment and child sexual abuse were not reported before 1960 . Then the age of childhood was changed to include adolescents, and "if in 1963 there were about 163,000 reports of child abuse, there were nearly 3 million in 1995" (Best 2001: 99). Should one consider that ill treatment and child sexual abuses have grown exorbitantly? Rather, an entire apparatus of detection and reporting has been set up, enlisting professionals to report all detected cases:

The figures of statistics measure not the frequency of the problem but new social attitudes and organizational schemes set up. However [in paedophilia cases, for example] militants stress these figures as proofs of the increasing seriousness of the problem and the need of new actions to conquer it. (Best 2001: 102)

Both social psychologists and folklorists have studied rumours. The former have focused on the social context and analysed the conditions under which rumours are generated, which generally involve a situation of crisis and uncertainty and the lack of trustworthy information (always true in this 'information explosion' age, if you insist on trustworthiness). Folklorists, on the other hand, have identified traditional narrative motifs in several successive waves of rumours and shown that these motifs can be transmitted through the continuous narration of legends, but can also, when social conditions are fulfilled, give rise to rumour panics (Klintberg 2014).

\section{The Slaughter of the Innocents}

The central question is that of the spontaneous, unthinking first move: the acceptance of the legends of organ theft, reliance upon the assumption that 
disappearances and kidnappings of children are mainly of collective and organised criminal origin, or adoption of the terrifying hypotheses that seem to cover all child abuse and child sexual abuse. This first impulse towards unthinking acceptance has deep roots, which must be considered in the sphere of symbolic thought, where symbols and fables flourish, where fears and wishes become fixtures in exemplary tales of horror. The names given to this sphere of thought vary from one author to another: for Claude Lévi-Strauss it is the savage mind (Lévi-Strauss 1962), for Michel-Louis Rouquette - natural or social thought(Rouquette 1973), for Nicole Belmont - mythical thought (Belmont 1984 [1968-1974]), for Peter Lienhardt - metaphorical or analogical thought (Lienhardt 1975). It is within each person (as is now recognised) that this symbolic thought mode 'alternates' with that of rational and reflexive thought so that two opposed approaches can coexist.

Magical reasoning attributes extraordinary powers to body fluids and extreme efficiency to innocence. These ideas contribute to universal conceptions of exchange and sacrifice that persist in the modern world and that can even be said to be gaining ground today with the growing popularity of alternative beliefs and lifestyles that repudiate the dictates of science and rationalism.

Centred on the preys, or the victims, the legends that I have discussed point to organised organ thefts, criminal kidnappings, and abuse by quasisupernatural predators that prowl about among us. It is evident that in the 21 st century, criminals occupy the space that in traditional societies was devoted to malevolent entities. They bring to mind the immemorial tale of the slaughter of the innocents, known more or less by everyone.

The core of this tale, which has been embedded in numerous stories in multiple cultures for centuries, is that young children from the storyteller's social group are being abducted and murdered, or ritually slaughtered, by evil-doers. The main outlines to be found in these various cycles can be summed up as follows:

Conspiracy is unmasked. An incomprehensible and meaningless coincidence is replaced by something that makes sense of the situation, although it is malevolent in nature.

- Victims are the children of the group, simultaneously its weakest elements and the embodiment of its future. Their extreme innocence makes them magically powerful and hence precious to the evil-doers.

- The evil-doers are, most often, either hostile foreigners or members of culturally different minorities living within our 'normal' society. But they may also be social deviants who seem, at first, to belong to our culture, e.g. criminals, heretics, or sorcerers. 
- This extraordinarily adaptable story can express normal people's fear of deviants, minorities, and foreigners, but also the ruling elites' fears of the poor and minorities. The evil-doers can also be the group's own rulers, own elites. This has been especially true in situations of colonisation or conquest, where the rulers were foreigners.

- The victims are eaten, emptied of their blood or their fat, and their vital forces are absorbed by the evil-doers. Often the evil-doers are sick or in some ways defective, and the victims possess the precious and unique element that can cure them or supply what they lack.

Christian culture has developed specific narrative cycles that incorporate and adapt the tale of the slaughter of the innocents. Thus, by denouncing outsiders, the ritual murder targeted Jews - or, the devilish pact is said to involve witchcraft.

The tale is extremely flexible and can express dominant fears, but also those of marginalised groups. The Topsy/Eva cycle identified by Patricia Turner (1993), in which identical rumours circulate in polarised communities and are adapted to make sense in each, comes to mind. The tale is then inverted as one of these optical illusions whose salient features become hollow and target the elites. In colonial and post-colonial societies the foreign masters, and today the rich, having adopted modern ways, continue to be perceived as vampires and sorcerers who devour children.

Dark legends play an important role as a mobilisation tool when a new social problem appears - or, rather, when a condition is successfully designated as a new social problem by claims-makers. Dark legends are elaborate versions that overstate disturbing facts, conflict-ridden social situations, and tense situations between social or ethnic groups. Often disseminated or fabricated by propagandists who find in these disquieting and sensationalist tales a way to mobilise publics for their own interests, these cycles of dark legends have followed and referenced each other by adapting themselves to the diverse historical circumstances from which they have emerged. It is most often the long-standing tale of the slaughter of the innocents that serves as a catalyst for these chilling tales and demonologies.

\section{The Extreme, the Concept of the Utmost}

Contemporary legends often seem to be rhetorical exercises built on the two processes of hyperbole, or the practice of exaggerating with the goal of attracting attention and advancing a particular view, and of extreme oppositions.

Hyperbole, which is a conscious exaggeration in order to persuade, is a standard tool of the claims-makers. In his recent analysis of Crime Legends, 
Peter Burger (2014b) discusses its use in the 'drugged and abused' (white slave trade) and the 'Smiley Gang' themes.

To stage extreme oppositions, the legends employ metaphors revolving around the theme of the utmost, to which I will now turn.

French dictionaries (Larousse 1869; Rey 1994) specify that the utmost, a dramatic form of the extreme, is both the most of (from the Latin culmen: the highest) and too much of (from the Latin cumulus: excess of). Different in their proper senses, the two Latin terms are united when used figuratively, always in a pejorative sense.

One example of the utmost of savagery is the exotic big cat, whose pseudoappearances have haunted the French and British countryside since some fifty years; the utmost of cruelty are these razor-blade cuts at the corners of the mouth inflicted by the Smiley Face Gang to their victims and that have disfigured Victor Hugo's Laughing Man (L'homme qui rit, 1869), as well as the Joker in Batman.

The notion of the utmost was introduced in 1962 by semiotician Roland Barthes in his analysis of the structure of fait divers (roughly equivalent to the human interest stories in U.S. newspapers in the 1940s). Barthes pointed out then that the fait divers was built up through the presentation of a dysfunction in the relations of causality and coincidence. Especially important were these coincidences so perfectly opposed that they overturned stereotypes. Barthes' example was the headline, "In Little Rock (AR) the police chief murders his wife" . Such extreme coincidences become meaningful, transforming chance or hazard into fate or destiny. In the rhetorical construction of these 'utmost' oppositions events become signs, but signs whose meaning is practically impossible to decipher (Barthes 1972).

In their 1947 Psychology of Rumour, social psychologists Gordon Allport and Joseph Postman used three terms to describe the movement of rumour: levelling, sharpening, and assimilation. The sharpening process, which refers to the selection of details in the transmission process studied by the authors, can be incorporated in the evolution towards the extreme. It is thus clear that resorting to the utmost is a reinforcement process, broadly spontaneous, which structures the understanding of faits divers and the elaboration of the plots of many contemporary legends.

\section{The Obsession}

After centuries of denial and neglect, what are the reasons for this long-lasting obsession with child abuse, and especially child sexual abuse? In a society 
plagued by uncertainty, and fearing the future, the notion that contemporary evil can be explained by looking to a demonised past may seem to offer a solution.

The taboo against sexual relations with youngsters has grown in parallel with the development of sexual permissiveness. Between consenting adults, everything is possible. Society organises and exacerbates desire but the means of its fulfilment are not provided.

If evil is situated outside, in the almost demonic sexual predator, the question of our own urges that may be evil need not be raised, and it is convenient to forget that $92 \%$ of sexual abuses are perpetrated within the family and close circle of friends.

It is impossible to dream of a return to the good old days of silence and denial; it is only by renouncing the eradication of evil as a goal that the combat for children can be both compassionate and rational, as well as truly effective. ${ }^{9}$

\section{APPENDIX}

\section{Imagined Sexual Aggressions and Molestation of Foreigners Erroneously Identified as Paedophiles, France 2010-2013}

(Aron \& Cognard 2014: 126-138)

Practically every week police forces are alerted about a sexual aggression against a child or a kidnapping that is revealed to be false. The following list concerns cases that took place in 2010 and 2011 and entailed police inquiries:

Reims (east of France), September 16, 2010. A paedophile dressed as Zorro is said to try to kidnap children near schools.

North of France, September 30, 2010. A couple in their sixties (she is a redhead wearing thick glasses) is said to drive near schools, trying to kidnap children. A Facebook page is created.

Bonneville (southeast Alps), early 2011. An English couple that has stopped to ask directions is mistaken for a pair of kidnappers and the police surround the village school.

Delle (near Belfort, east), January 26, 2011. A mother complains at the police station that two men in a white van, one of them bald, have tried to kidnap her 9-year-old daughter leaving school, by offering her sweets. Fantastic tales then surge in the community, thus Eastern Europeans are said to have killed four people leaving a nightclub (and stolen their organs). The police organise an investigation of all white vans to calm the people, thus validating the crazy rumours.

Lèves (southwest of Paris), January 2011. Rumours of sexual fondling entail the medical examination of a little schoolgirl. 
Allier (central France), January 2011. An outdated picture of a sexual criminal circulates and causes panic.

Côtes d'Armor (Brittany, west), February 2011. A white van with a kidnapper of little girls and organ traffickers.

Toulouse (southwest), March 2011. The same story of a white van, a kidnapper, and organ traffickers.

Strasbourg (east), April 2011. The same story of a white van, a kidnapper, and organ traffickers.

Picardie (northeast), May 2011. The same story of a white van, a kidnapper, and organ traffickers. The mayor of Beauvais denies it.

Lille (north), June 2011. The same story of a white van, a kidnapper, and organ traffickers.

Teil (southeast), June 2011. Two little girls escape kidnapping outside a school.

Three more serious incidents occurred in this climate of fear. In Marseilles (south), in May 2008, the disappearance of Fatima Saiah (aged 21, on her way to a baby-sitting appointment; still unsolved in 2014) entailed a strong community mobilisation. Shortly afterwards, the rumoured white vans driven by Eastern Europeans belonging to the 'organ mafia' are said to have been prowling around schools to kidnap children. On June 21, 2008, the day of the Music Feast, when everyone was outside dancing, three men who were Roma from Romania - a community of some 1,500 was settling in these Northern districts of Marseilles mainly inhabited by populations originally from North Africa were spotted searching in refuse bins for copper bits. They were designated by an excited crowd as 'the organ thieves', their van was burned, they succeeded to escape and found refuge on the roof of a snack bar where it took over 40 police officers with Flash Balls to liberate them from the lynching mob and take them to a hospital. No charges were filed.

On November 28, 2011, in Brest (Brittany), a 65-year-old Jean Claude Basset was smoking outside the apartment where he had been staying since April, just across the kindergarten school. This retiree with a strong southern accent (he used to work in the shipyards at Toulon) and of a rather shabby appearance, was under care for mental health issues and had been hospitalised for depression. On November 18, he had helped to bring back to school a 3-year-old little girl who had disappeared before her mother's eyes and this incident aroused the neighbours' suspicion. Suddenly some 10 to 15 mothers who were waiting for their kids outside the school rushed upon him, shouting insults. He took refuge in the building's hallway and shortly afterwards the police arrived. The policemen handcuffed him and transported him in their van when suddenly he fell on the floor, victim of a heart attack. A cardiac massage proved futile 
and Basset arrived dead at the city hospital. Since he carried no trace of blows, no charges were filed - the assailants were considered as 'actors of good faith' and the prosecutor declared to the press: "It is rumour that killed Jean-Claude Basset".

August 31, 2013. When the ferry Excelsior, coming from Marseilles, landed in Ajaccio (Corsica) in the evening, a pre-riot atmosphere broke out, fuelled by several alarming messages from mobile phones. It was said that "a group of kids back from a trip to Barcelona have been targeted by a party of Roma on the ship. There have been sexual fondling, kids - boys or girls - cornered in an elevator, pictures taken..." (Luccioni 2013).

The ship's captain identified 16 men, aged 30 to 50, who did not speak French; the police took them ashore and then to the police station in vans that passed with great difficulty through the crowds of people who were shouting insults and hitting the vehicles. Two kids talked to the police but no inappropriate conduct was detected. It appeared the kids were playing ball in the ship corridors and the men briefly joined in. The ball was taken - and given back. The men were Portuguese and regular farm workers in the vicinity of Ajaccio, their mobile phones revealed no inappropriate pictures and they were released. The comments of the article published the following Monday can apply not only to Corsica but also to France as a whole:

The facts are revealing. Fantasies that occur in a part of the population, which routinely sees in the other, especially if it is a foreigner, an immediate threat. And reveals the hidden face of a Corsican that cowers for imaginary terrors sustained by rejection and xenophobia. Worrying. (Luccioni 2013)

\section{NOTES}

1 Hereinafter translations of the quotations not originally in English are from the author.

${ }^{2}$ See www.police-nationale.interieur.gouv.fr/Organisation/Direction-Centrale-de-la-PoliceJudiciaire/Lutte-contre-la-criminalite-organisee/Office-central-pour-la-repression-desviolences-aux-personnes, last accessed on July 28, 2015.

3 See http://www.116000enfantsdisparu.fr/presentation.html, last accessed on July 28, 2015.

4 See https://en.wikipedia.org/wiki/The_Courage_to_Heal, last accessed on July 28, 2015.

5 See http://www.ice.gov/news/releases/internet-predator-group-member-sentenced-15years-prison-engaging-child-exploitation, last accessed on July 28, 2015. 
6 Available at http//content.met.police.uk/News/Giving-Victims-a-Voice/1400014181251/1257246745756, last accessed on July 28, 2015.

7 See http://www.egaliteetreconciliation.fr/, last accessed on September 10, 2015.

8 See http://archives.chicagotribune.com/1960/03/20/page/53/article/little-rock-chief-killswife-and-self, last accessed on November 12, 2015.

9 Drawn from a presentation given on April 5, 2014, at the workshop on new forms of mediations, organised by Michael Houseman and Marika Moisseeff (Collège de France, Paris).

\section{REFERENCES}

Ansión, Juan 1989. Pishtacos: De verdugos a sacaojos. Lima: Tarea.

Aron, Matthieu \& Cognard, Franck 2014. Folles rumeurs: Les nouvelles frontières de l'intox. Paris: Stock.

Barthes, Roland 1972. Structure of the Fait Divers (orig. publ. 1962 in Médiations). In: R. Barthes. Critical Essays. Transl. by Richard Howard. Evanston: Northwestern University Press, pp. 185-196.

Belmont, Nicole 1984 [1968-1974]. Folklore. Encyclopedia Universalis. Paris: Ed. Encyclopedia Universalis. Available at http://www.universalis.fr/encyclopedie/folklore/, last accessed November 11, 2015.

Beneux, Laurence \& Garde, Serge 2001. Le livre de la honte: Les réseaux pédophiles. Paris: Le Cherche Midi.

Bensussan, Paul \& Rault, Florence 2002. La dictature de l'émotion: La protection de l'enfant et ses dérives. Paris: Belfond.

Best, Joel 1987. Rhetoric in Claims-Making: Constructing the Missing Children Problem. Social Problems, Vol. 34, No. 2, pp. 101-121. http://dx.doi.org/10.1525/ sp.1987.34.2.03a00010.

Best, Joel 1990. Threatened Children: Rhetoric and Concern About Child-Victims. Chicago \& London: The University of Chicago Press.

Best, Joel 2001. Damned Lies and Statistics: Untangling Numbers from the Media, Politicians, and Activists. Berkeley \& Los Angeles \& London: University of California Press.

Best, Joel 2002. Constructing the Sociology of Social Problems: Spector and Kitsuse Twenty-Five Years Later. Sociological Forum, Vol. 17, No. 4, pp. 699-706. Available at http://link.springer.com/article/10.1023/A\%3A1021037709754, last accessed on September 15, 2015.

Black, Tim 2013. Jimmy Savile: The Satanic Panic Resurrected. Jean La Fontaine on the Savile Case's Eerie Echoes of Past Hysteria. Spiked, July 1. Available at http://www.spiked-online.com/newsite/article/jimmy_savile_the_satanic_panic_ resurrected1/13765\#.VfFal31y73U, last accessed on September 10, 2015.

Brandon, S. \& Boakes, J. \& Glaser, D. \& Green, R. 1998. Recovered Memories of Childhood Sexual Abuse: Implications for Clinical Practice. The British Journal of Psychiatry, Vol. 172, pp. 296-307. http://dx.doi.org/10.1192/bjp.172.4.296. 
Brunvand, Jan Harold 1986. The Mexican Pet: More "New" Urban Legends and Some Old Favorites. New York \& London: W.W. Norton \& Company.

Burger, Peter 2014a. AD brengt gerucht als nieuws: Kris en Lisanne slachtoffer van orgaanroof. [AD Presents Rumour as News: Kris and Lisanne Victims of Organ Harvesting.] Available at http://www.gestolengrootmoeder.nl/wordpress/geruchtals-nieuws-vermiste-kris-en-lisanne-slachtoffer-van-orgaanroof/, last accessed on September 15, 2015.

Burger, Peter 2014b. Monsterlijke verhalen: Misdaadsagen in het nieuws en op webforums als retorische constructies. [Monster Tales: Crime Legends in the News and on Internet Forums as Rhetoric Constructions.] Den Haag: Boom Lemma.

Campion-Vincent, Véronique 1990. The Baby-Parts Story: A New Latin American Legend. Western Folklore, Vol. 49, No. 1 (Special issue: Contemporary Legends in Emergence), pp. 9-25. http://dx.doi.org/10.2307/1499480.

Campion-Vincent, Véronique 1997. Organ Theft Narratives. Western Folklore, Vol. 56, No. 1, pp. 1-37. http://dx.doi.org/10.2307/1500384.

Campion-Vincent, Véronique 2004. The Social Climate and Scare Stories about Children: An Overview and Evaluation. In: A. Palàdi-Kovàcs (ed.) Times, Places, Passages: Ethnological Approaches in the New Millennium. 7th SIEF Conference, Budapest, April 23-28, 2001. Selected Papers. Budapest: Akadémiai Kiadó, pp. 481-495.

Campion-Vincent, Véronique 2005. Organ Theft Legends. Transl. by Jacqueline Simpson. Jackson, MS: University Press of Mississippi.

Campion-Vincent, Véronique 2006. Élites maléfiques et 'complot pédophile': paniques morales autour des enfants. Schweizerisches Archiv für Volkskunde / Archives suisses des traditions populaires, Vol. 102, No. 1, pp. 49-70. Available at http:// retro.seals.ch/digbib/view?rid=sav-001:2006:102::62\&id=browse\&id2=browse2, last accessed on September 15, 2015.

Campion-Vincent, Véronique 2008. Comme un abus d'enfance. Paris: Seuil.

Conrad, Joann 1998. Stranger Danger: Defending Innocence, Denying Responsibility. Contemporary Legend, Vol. 1, pp. 55-96. Available at http://collections.mun. $\mathrm{ca} / \mathrm{cdm} /$ compoundobject/collection/clegend/id/2335/rec/7, last accessed on September 15, 2015.

Cree, Vivienne \& Clapton, Gary \& Smith, Mark 2014. Moral Panics, Jimmy Savile and Social Work: A 21st Century Morality Tale. Discover Society, No. 4, January 6. Available at http://www.discoversociety.org/2014/01/06/moral-panicsjimmy-savile-and-social-work-a-21st-century-morality-tale/, last accessed on September 15, 2015.

Crews, Frederick C. 2004. The Trauma Trap. The New York Review of Books, Vol. 51, No. 4. Available at http://www.nybooks.com/articles/archives/2004/mar/11/thetrauma-trap/, last accessed on September 9, 2015.

Davey, Monica \& Goodnough, Abby 2007a. Doubts Rise as States Hold Sex Offenders after Prison. New York Times, March 4. Available at http://www.nytimes.com/2007/03/04/ us/04civil.html?pagewanted=all\&_r=0, last accessed on September 15, 2015.

Davey, Monica \& Goodnough, Abby 2007b. A Record of Failure at Center for Sex Offenders.

New York Times, March 5. Available at http://www.nytimes.com/2007/03/05/ us/05civil.html?pagewanted=all, last accessed on September 15, 2015.

Davey, Monica \& Goodnough, Abby 2007c. For Sex Offenders, a Dispute over Therapy's Benefits. New York Times, March 6. Available at http://www.nytimes. 
com/2007/03/06/us/06civil.html?pagewanted=all, last accessed on September 15, 2015.

Delay, Chérif \& Garde, Serge 2011. Je suis debout: L'aîné des enfants d'Outreau sort du silence. Paris: Le Cherche Midi.

Donadini-Rousseau, Mireille 1998. Le discours social de la rumeur et le monde vécu. Montréal: Université du Québec à Montréal.

Egan, R. Danielle 2013. Moral Crusades in an Age of Mistrust: The Jimmy Savile Scandal by Frank Furedi. Times Higher Education Supplement, May 23. Available at https://www.timeshighereducation.co.uk/books/moral-crusades-in-an-age-ofmistrust-the-jimmy-savile-scandal-by-frank-furedi/2003935.article, last accessed on September 16, 2015.

Fass, Paula S. 1997. Kidnapped: Child Abduction in America. New York \& Oxford: Oxford University Press.

Furedi, Frank 2013a. Moral Crusades in an Age of Mistrust: The Jimmy Savile Scandal. Basingstoke, UK: Palgrave Macmillan. DOI: 10.1057/9781137338020.

Furedi, Frank 2013b. After Savile: Policing as Entertainment. Spiked, April 29. Available at http://www.spiked-online.com/newsite/article/13580\#.VFsmmDSG_nh, last accessed on September 10, 2015.

Garde, Serge 2013. Outreau l'autre vérité. Documentary.

Gray, David \& Watt, Peter 2013. Giving Victims a Voice. Available at http://content. met.police.uk/News/Giving-Victims-a-Voice/1400014181251/1257246745756, last accessed on September 10, 2015.

Gryson-Dejehansart, Marie-Christine 2009. Outreau la vérité abusée. Paris: Hugo et Compagnie.

Hume, Mike 2013. Operation Yewtree: Putting the Past on Trial. Spiked, January 14. Available at http://www.spiked-online.com/newsite/article/13251\#.VkXx517pYQ1, last accessed on November 11, 2015.

Jenkins, Philip 1996. Paedophiles and Priests: Anatomy of a Contemporary Crisis. Oxford \& New York: Oxford University Press.

Jenkins, Philip 1998. Moral Panic: Changing Concepts of the Child Molester in Modern America. New Haven \& London: Yale University Press.

Journal Officiel $1995=$ Loi n $^{\circ}$ 95-73 du 21 janvier 1995 d'orientation et de programmation relative à la sécurité. Article 26. Légifrance. Available at http://www.legifrance. gouv.fr/affichTexte.do?cidTexte=LEGITEXT000005617582, last accessed on September 16, 2015.

Kempe, C. Henry \& Silverman, Frederic M. \& Steele, Brandt F. \& Droegemueller, William \& Silver, Henry K. 1962. The Battered Child Syndrome. Journal of the American Medical Association, Vol. 181, No. 1, pp. 17-24.

Klintberg, Bengt af 2014. The Human Sausage Factory: A Study of Post-War Rumour in Tartu. Journal of Baltic Studies, Vol. 45, No. 2, pp. 272-274. DOI:10.1080/0 1629778.2014.892245.

La Fontaine, Jean S. 1998. Speak of the Devil: Tales of Satanic Abuse in Contemporary England. Cambridge: Cambridge University Press.

Larousse, Pierre (ed.) 1869. Grand Dictionnaire universel du XIX ${ }^{e}$ siècle. Vol. 4. Paris: Administration du Grand Dictionnaire Universel. Available at http://www. archive.org/stream/LarousGrdictionnXIX04bnf\#page/n10/mode/1up, last accessed on September 16, 2015. 
Lévi-Strauss, Claude 1962. La pensée sauvage. Paris: Plon. Available at http://monoskop. org/images/f/f6/Levi-Strauss_Claude_La_Pensee_sauvage_1962.pdf, last accessed on November 16, 2015.

Lienhardt, Peter 1975. The Interpretation of Rumour. In: J. H. M. Beattie \& R. G. Lienhardt (eds.) Studies in Social Anthropology: Essays in Memory of E. E. EvansPritchard. Oxford: Clarendon Press, pp. 105-131.

Loftus, Elizabeth \& Ketcham, Katherine 1994. The Myth of Repressed Memory: False Memories and Allegations of Sexual Abuse. New York: St Martin's Press.

Luccioni, Isabelle 2013. A Ajaccio, la rumeur de sévices sexuels a failli tourner au lynchage. Corse-Matin, September 2. Available at http://www.corsematin. com/article/ajaccio/a-ajaccio-la-rumeur-de-sevices-sexuels-a-failli-tourner-aulynchage.1130991.html, last accessed on September 14, 2015.

Molinié Fioravanti, Antoinette (ed.) 1991. El Pishtaco. Bulletin de l'Institut Français d'Etudes Andines, Vol. 20, No. 1, pp. 1-92. Available at http://www.ifeanet.org/ publicaciones/detvol.php?codigo=178, last accessed on November 16, 2015.

Moore, Suzanne 2013. Moral Crusades in an Age of Mistrust: The Jimmy Savile Scandal Crusades by Frank Furedi. Review. The Guardian, March 13. Available at http:// www.theguardian.com/books/2013/mar/13/moral-crusades-frank-furedi-review, last accessed on September 10, 2015.

Rey, Alain (ed.) 1994. Dictionnaire historique de la langue française. Vol. 1. Paris: Dictionnaires Le Robert.

Richardson, James T. \& Best, Joel \& Bromley, David G. (eds.) 1991. The Satanism Scare: An Anthropological View. New York: Aldine de Gruyter.

Roper, Derek 1997. More Mall Kidnapping Stories. FoafTale News, Vol. 42, No. 10. Available at http://www.folklore.ee/FOAFtale/ftn42.htm, last accessed on September 8, 2015.

Rouquette, Michel-Louis 1973. La pensée sociale. In: S. Moscovici (ed.) Introduction à la psychologie sociale, Vol. 2. Paris: Larousse, pp. 298-328. Available at http:// classiques.uqac.ca/contemporains/moscovici_serge/intro_psycho_soc_t2/intro_ psycho_soc_t2.pdf, last accessed on September 16, 2015.

Spector, Malcolm \& Kitsuse, John I. 1987. Constructing Social Problems. New York: Aldine de Gruyter.

Tardieu, Ambroise 1857. Étude médico-légale sur les attentats aux mœurs. Paris: J. B. Baillière et Fils.

Tardieu, Ambroise 1860. Étude médico-légale sur les sévices et les mauvais traitements exercés sur des enfants. Annales d'hygiène publique et de médecine légale, $2 \mathrm{e}$ série, tome XIII, pp. 361-398.

Thomet, Jacques 2013. Retour à Outreau: Contre-enquête sur une manipulation pédocriminelle. Paris: Kontre Kulture.

Turner, Patricia A. 1993. I Heard It Through the Grapevine: Rumour in African-American Culture. Berkeley \& Los Angeles \& London: University of California Press.

Van der Kolk, B. A. \& Van der Hart, Onno 1991. The Intrusive Past: The Flexibility of Memory and the Engraving of Trauma. American Imago, Vol. 48, No. 4, pp. 425454. Available at http://www.pep-web.org/toc.php?journal=aim\&volume=48, last accessed on September 9, 2015.

Zéro, Karl 2014. Disparues: Que sont-elles devenues? Paris: L’Archipel. 


\title{
SEEKING BORDERS AND THEIR MYTHOLOGY IN WESTERN THRACE, GREECE
}

\author{
Evangelos Avdikos
}

\begin{abstract}
This article deals with the boundaries of western Thrace, a Greek region bordering both the Bulgarian (northern) and Turkish (eastern) Thrace. The main aim here is to re-contextualise the perspective of the residents of western Thrace on Thracian borders. Such an interpretive process has to take account of the political changes in the southern part of the Balkan Peninsula after the collapse of the communist regime in Bulgaria and the increasing incorporation of Greece into the political structures of the European Union.
\end{abstract}

Keywords: border, Bulgaria, European Union, Greece, identity, liminality, migration, Pomaks, Turkey

The aim of this article is to explore the function of the border of western Thrace, the furthest and easterly area of Greece, which, in the east, shares a border with Turkey. Specifically, Greek (eastern) Thrace is a part of the historic and geographical area of Thrace which today consists of two other parts belonging to Bulgaria (northern Thrace) and Turkey (eastern Thrace). What changes occurred in the perception of the border over the 20th century? What was the role of older narrative motifs in the representation of the border? And what is the situation at the beginning of the 21st century, assuming that Greek borders are also the borders of the European Union? How - and to what extent - is the geographical border related to the invisible borders between the ethnic groups of the Muslim minority, on the one hand, and between the Christian and the Muslim population on the other hand.

\section{THE THEORETICAL FRAMEWORK}

This paper makes use of autoethnography, which has been of great value in the process of revealing the importance of subjectivity. "Autoethnography is a qualitative research method that utilizes data about self and its context to gain an understanding of the connectivity between self and others within the 
same context" (Ngunjiri \& Hernandez \& Chang 2010: 2). Autoethnography borrows the theoretical reflections of anthropological thought, with the aim of overcoming misgivings about feelings and an obsession with generalisability; that is, the researcher is attempting to find a balance between him/herself and the other. This theoretical and methodological framework facilitated my fieldwork and relations with my informants. My academic presence in Thrace over a long period of time (Narayan 1993: 671-686) and my public intervention created a framework for communication, which eased the transition from private to public discourse. My research in Thrace formed a part of my academic autobiography. This created a favourable atmosphere for discussions with my numerous informants, who were both ordinary citizens and members of the intellectual, financial, and social elite.

I was led to consider whether private conversations on all these matters are in fact representations of otherness and ethnic boundaries disseminated through public networks or whether such private conversations rest on ideas and motifs deeply rooted in a previous historical environment (Brunnbauer 1999: 40). Let me give an example. "You do not live in the area yet. Thrace has changed. Swarms of immigrants come down from the northern Evros." These phrases were uttered by a close friend in Alexandroupolis, in Greece. She is not politically conservative and is indeed an open-minded person, radical, and opposed to any nationalistic perceptions of otherness. Could we attribute the content of a private conversation about migrants and boundaries exclusively to the influence exercised by public discourse? Is history, when made in the present, not engaged in conversation with the past? Such an ahistorical position cannot be maintained. Thus I think it useful for my approach to attempt to trace motifs in private narratives that cause people to easily accept ideas and perceptions regarding otherness and its symbols (Linke 1990: 118). "I am afraid that I will not take pleasure in my house. Some Turks have been living in it," added the abovementioned colleague.

Is such a perception an exception? It most certainly is not. In these cases the use of both long-term research and researcher autobiography is unavoidable. Eight years (1992-2000) of teaching and research presence in the Evros area, which gave me a chance to conduct fieldwork in various localities in this region and to have conversations with many inhabitants, mainly in the context of daily life outside my research, in places across the Evros prefecture, contributed to the understanding of the historical, cultural, and social context of Thrace by me as an investigator from the outside. However, it also facilitated my identifying with the inhabitants of Thrace, with the result that they more or less regarded me as a local. The fact that I had, then, to transmute from an external to an 
internal observer, and also move in the opposite direction, which was achieved through reflexivity, contributed to a fuller understanding of many perceptions held by local people, relating to such concepts as boundary, ethnic/national otherness, and cultural practices. Thus I am convinced that this scepticism is not a limited phenomenon.

\section{Narrative Representations before the Second World War}

What occurred in the Balkans after the communist regimes collapsed forms an appropriate framework for contextualising the narrative on boundaries in Thrace. All these ethnic clashes called into question a very strict dipole relating to the stereotype of continuity that has been identified with the nation-state. Boundary as a concept has been ingrained in human minds and practices since the distant past and obviously before the nation-state emerged. Borders are usually considered state boundaries. However, they form a symbolic expression of every form of power and of ethnic groups that have felt a need to form distinctions (Gielis 2009: 599; Van Houtum 2005: 672-679). The example offered by the Balkans is very useful for grasping the idea of a boundary as a pre-national motif, which is then infused into various cultural forms that are reinvented in pursuit of national demands (Strüver 2003: 166-167; Görög-Karady 1992: 114-126).

Clearly, the only way to untangle this is to go back to the matter of how history is transformed into a mythology that contains the nuclei of historical facts now located in another historical, social, and political environment (Herzfeld 1989 [1987]: 123-149). This means that we need, in the case of western Thrace, to examine how the border of Thrace is linked with events both historical and re-invented. The first independent Greek nation-state was created in 1830. The border with Turkey was fixed by the Treaty of Lausanne in 1923, whereby the state of Turkey was established, replacing the Ottoman Empire that had existed here for about four hundred years.

This is the problem behind the discussion on the future of property in the Evros area and the dam, the so-called frachtis. Is there any interrelationship between these two issues? At first sight it may seem possible to connect one with the other. However, history - or its representations - and narratives can show that such an interrelationship is not bizarre. Various narrative forms are imbued with otherness expressed in large numbers. In particular, boundaryrelated narratives are organised around the border and how it creates the relationship of the self to the other (Paredes 1995 [1993]: 19-48). 
Let us take an example. In some erotic songs, the whole idea revolves around a potential marriage between a Greek girl and a Turkish man (Avdikos 2007: 104-121). The girl's mother focuses on how rich the Turk is and on the fact that if the daughter marries him, she will ensure her wellbeing. However, the girl disagrees with her mother and considers a range of ways to escape this marriage. All such songs display an ambiguous attitude towards Turkish otherness. On the one hand, there emerges a tendency towards co-existence, if not towards a blurring of ethnic borders, and on the other hand, songs express insistence on a strict representation of a line defining ethnicity.

This conflict, it should be noted, is not static and unchanging over time. It depends on the historic environment. Thus the defining line between Greece and Turkey, especially since the integration of the Evros area into the Greek nation-state in 1919, did not originally depict a conflicting representation in both public and private discourses. The Greek-Turkish border clearly demarcated the eastern end of Greek territory from 1920 onwards, after the signing of the Treaty of Sévres (Akçam 2004). However, in daily life, the River Evros did not actually function as a strict boundary on either bank. Many Greeks faced difficulties because they had resisted the German-Bulgarian occupation (1941-1944) and were forced to escape from Greece and seek refuge in Turkey. Furthermore, during the 1950s and 1960s residents on both sides co-operated over fishing and hunting (Avdikos 1998: 262). For locals, the border was not a barrier.

\section{The Cold War Narratives}

It is difficult, anyway, for the border to tell the same story. "This means that the perceptions of borders differ when they focus on different parts of the border" (Laube \& Roos 2010: 32). In western Thrace the border is to be regarded in a context of various stories that show the different historical past and the quality of relations with bordering peoples.

As regards Turkey, these narratives illustrate the historical and political relations between the two states (Rizas 2009: 367-387) that were political allies, in that both countries belong to NATO. They thus belonged to the camp of the West, in contrast to Bulgaria, which belonged to the opposing camp. To a great extent, the Greek-Turkish border was constituted by the River Evros, which separated the western, that is, the part that belonged to Greece, from the eastern Thrace, which had been granted to Turkey. There were certainly close relationships between inhabitants on either side of the border and the two states developed friendly relations after the Ankara Convention of 1930 
(Demirözü 2008: 313-314). Many Greeks who lived on the Greek bank of the River Evros were refugees from the opposite side (today the European or eastern Thrace). The same was the case with many inhabitants on the Turkish side of the river. Thus the inhabitants shared a common feeling of nostalgia for the ancestral land that they had been compelled to leave (Stuckey 2009: 14). They also shared common memories.

However, the situation radically changed after the so-called Septemvriana (September Events) in 1955 (Zayas 2007: 137-138; Alexandris 1992). ${ }^{1}$ The occasion for this orchestrated uprising in 1955 on the part of the inhabitants of Constantinople was a false rumour that Greeks had set fire to the house in Thessaloniki in which Kemal Ataturk, the founder of the modern Turkish state, had been born. The houses and property of the Greeks of Constantinople were destroyed. This led to mass migration to Greece and the drastic reduction in size of the Greek minority (Vryonis 2005). These events directly influenced the functioning of the border. The Evros area began to show a dangerous level of pollution, which caused the cessation of communication and collaboration in fishing and hunting. Both sides of the border turned their backs on each other, turning in upon themselves. Matters deteriorated yet further after the Turkish invasion of Cyprus in 1974, which made the border even more 'polluted' and dangerous. Thus Thrace and the Evros area became a military camp. Indicative of this is the fact that the Greek-Turkish border acquired a negative symbolism. For a long period it had been a place of exile and national exclusion for citizens with political views that put them among the 'tainted' in the Cold War (Tsibiridou 2005: 66), thanks to the Civil War, or those exiled there may have committed some administrative offence and fallen into disfavour in the eyes of their superiors in the civil service. The threat that public servants of the Greek state faced was that of social stigmatisation and geographical isolation, that is, what has been termed 'spatial strategy' (Certeau 1980).

Keep silent, Lady Virgin. Again with the years and time, it will be ours. (Ioannou 1977: 91)

Oral literature provides a motif, albeit in inverted form. Both the Agia Sofia song ${ }^{2}$ and the perception of the future of Greek Thrace are based on a historical substratum resting on an eschatological view of history (Andriomenos 2011: 24-27). The analysis that anthropologist Michael Herzfeld has performed on the song is particularly successful (Herzfeld 1986: 124-139). He devotes the sixth chapter (Expansion and Collapse) of his study to the song. He also maintains that there is an eschatological concept of history that led many to avoid active support to the struggle for national independence. Herzfeld agrees with Politis (1918: 151-170), the founder of Greek folklore, that this song embodies 
various prophecies according to which the last emperor, turned to marble, will return and enter Constantinople in triumph. Herzfeld also agrees with Politis that such prophecies fed the expectation of liberation. Herzfeld, however, differs from Politis as regards the former's view that this motif is an indication of cultural continuity. In any case, the last verse was a main source of hope for the renaissance of Hellenism.

In other words, such a discourse is conditioned by a determinist outlook. Thus the territory and borders merely constitute a temporary situation before eschatology is redeemed. This view is directly related to the historical relations between Greeks and Turks in the context of the Ottoman Empire that formed the stereotypes of otherness, and "the threatening Turk" (Hirschon 2008: 88), who, in an abstract fashion, in a private discourse, is regarded as a source of unending enmity and as the "other of Greeks" (Theodossopoulos 2006: 3). The various forms of both the spoken discourse, such as riddles, proverbs and songs, and of the private discourse have created the figure of the Turk as a barbarian, a harsh and bloodthirsty conqueror. This image of the Turk finally became clear and definite with the Treaty of Lausanne. Thrace gradually became a volatile region, thanks to the institutionalisation of a three-way pattern of conflict. In this were caught up the Muslim minority, Greece as the state in which the minority was resident, and Turkey as an external national entity that was guarantor of the safety of its co-religionist minority. The Treaty of Lausanne gave Turkey the power to intervene in anything regarding relations between the Greek state and the minority, whenever they thought they were capable of exercising pressure. Thus the border functions as a mirror of the state of the Greek-Turkish relations.

The stereotype of the 'evil Turk' forms the historical and cultural background that favours Greeks' reformulation of images of Turks and vice versa. Some skeletons from the past have come out of the cupboard, with important consequences for the process of restating them and for their passage into a different context. Particularly after the Septemvriana and the invasion of Cyprus by Turkey in 1974, relations between Greece and Turkey worsened and Greeks and Turks do live in a state of national introversion and isolation, as regards their supposedly recalcitrant neighbour. National frontiers, particularly during the seven-year period of military dictatorship in Greece, between 1967 and 1974, are endowed with a symbolism of suspicion and hostility and are responsible for a 'victim complex' (Hirschon 2008: 87). In particular, the Greek-Turkish border on the River Evros has become the symbol of the 'danger from the East' (Troumbeta 2001: 50), a belief that is responsible for the formation of a feeling of fluidity on the spatial formulation of the frontiers. This atmosphere has contributed to the creation of what Ardener (1989: 69) has called a 'hollow category'. The 
conception of the Turk is formed through discrimination and prejudice that spring from various sources in the main national fears and suspicions.

All this is intimately associated with the process whereby the Greek nationstate was formed. It was created upon the independence of territories from the Ottoman Empire. The borders on the River Evros were the expression of the Sevres Treaty (10 August 1920), when Thrace was absorbed into Greece, the demonised Other, which, at least in the eyes of Greek public discourse, did not allow the question of borders in the area to be settled once and for good. The danger from the East that created the feeling that all was temporary on the borders led the whole of Thrace to a state of social and economic asphyxiation (Troumbeta 2001: 51), a fact that rendered the minority invisible for a lengthy period ending in the 1980s. State authorities remained indifferent, although they did not hinder the solution of the problems of the minority, such as housing and ownership. This was a period when, inter alia, the minority and thus also Turkey were portrayed as the expression of a dark and stigmatised past and culture of the East, which the Greeks wish to forget. It is a culture with which the Greeks feel uncomfortable, as it is identified with the 'backward Orient', whilst, as early as the 1960s, attempts were being made to complete the westernisation that has been a dream and a goal since the Greek War of Independence in the early 19 th century.

In addition to this view, yet another one of the area has come into existence since the early 1960s, when Greece became a member of the then European Community. As a result, the Evros authorities placed signs just inside the Greek border, for visitors coming from Turkey as they left the customs post at Kipi. These signs reminded the visitor that Alexandroupolis, the capital of the Evros area, was the first city in Europe that they would encounter. In general, after the Second World War, the River Evros became a symbol that distinguished citizens of Europe from the people who lived beyond the eastern bank of the river. Such people were regarded as oriental. As my informants said, this meant that people of the western bank, that is, Greeks, identified with progress. They feel that the Evros border separates two different worlds.

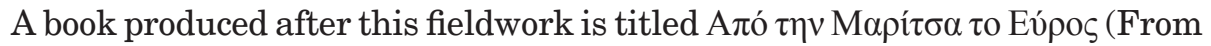
Maritsa to Evros; Avdikos 1998: 266). Maritsa (sometimes also called Martsa) is the Slavic name for the River Evros, which became the official name of the river immediately after the liberation and integration of western Thrace into the Greek state, on 14 May 1920. The Slavic name Maritsa, however, continued to be used in private discourse by those resident along the river. The Greek name Evros unofficially replaced the Slavic name in the first decades of the post-war period. For locals, however, the river remained the River Maritsa, a thread of cultural continuity that echoes the multicultural and multiethnic 
co-existence in this area as reflected in place-names. There are two important factors in regard to how the river was viewed up to the late 20th century. Firstly, Evros, the name employed in official discourse, is increasingly penetrating the unofficial speech of young generations, thanks to the effects of the educational system. Thus, in particular after the Septemvriana in Istanbul and the invasion by Turkish troops of Cyprus, it became the emblematic outpost of the territory of the Greek state. The name Maritsa, on the other hand, conveys the memory of a world and culture that have faded away.

In Levi-Strauss's view (1966: 181), "the name is an identifying mark". If we use this term and apply it to a political system, in this case to the process of creating the Greek nation-state, the change of name replaces, at a symbolic level, the historical and cultural continuity of the ethnos, which was interrupted by the Ottoman Empire. There is, nevertheless, yet another level to the discussion, which is to be linked with the change of political environment, with the move from the Ottoman Empire made up of many nations to a developing and homogenised nation-state that endeavoured to gain control from the start at the symbolic level of names and territorial domination. The change of name was expressive of a desire for communication, but was chiefly an act whereby power relations were made manifest (Cohen 1974: 16). So if we distinguish between private and public ways regarding the interpretation of symbols, then this theoretical framework facilitates the understanding of private and public discourses that are produced in Greece, pertaining to the name of the river and, more broadly, in relation to the orientation of the Greek state. In other words, we can understand that the nation-state built in Greece is organised around a contradictory principle. On the one hand, there is the orientation towards the West and the attempt to apply the principles of the Enlightenment to the organisation of the state. On the other hand, there is the inheritance of the Orient, experience arising from co-existence with many other ethnic groups. ${ }^{3}$ The Greek name Evros expresses, at a symbolic level, the intention of the Greek state to cut loose from the Ottoman and multicultural past.

\section{TRANSNATIONAL MIGRATION, EUROPEAN UNION, AND BORDERS}

The 1990s were of crucial importance in dictating how the borders of Thrace functioned and how they influenced the invisible borders between the majority community of Christians and the Muslim minority in Thrace. Since then, Greece has become more closely linked to the political structures of the European Union, a process which has had various consequences. The "internalisation of 
minority rights gained significant momentum towards the end of the twentieth century" (Memisoglu 2007). In the case of Greece, this was expressed in the form of various pressures on Greece to apply the measures passed by the European Union regarding the rights of members of the community as citizens of the Greek state.

Unavoidably, the Muslim minority in Greece is studied in the context laid down by international law regarding the rights of minorities, Greek-Turkish relations, and the relations that have developed within the Muslim minority. All these three factors negotiate visible and invisible boundaries. That is to say, they are influenced by the relations between Greece and Turkey and the views evolved regarding the Greek-Turkish border. They are also influenced by the legal decisions and political texts produced by the European Union (Tsitselikis \& Christopoulos 1997).

Public discourse has thus gradually incorporated European discourse and representations of a wide range of matters relating to how the Greek state functions. The European Union functions as a supra-national entity that reformulates relations within its nation-states. In the case of borders between Greece and Turkey, in western Thrace, this can be seen in the sign placed at the customs Post At Kipi, the main gateway from Turkey to Greece, reading, "Greece, the First Country towards the European Union". This slogan expressed both private and public discourses in the area. The borders between Greece and Turkey thus lay down hierarchies of national states. ${ }^{4}$

Greece, then, is adapting itself at a fairly speedy pace to the status quo laid down by the European Union, whilst at the same time Thrace is turning into a testing ground for multiculturalism, a new concept imported by the former (Tsibiridou 2009). As part of this, the existence of two conflicting concepts is to be noticed. On the one hand, there are the attempts on the part of the Muslim community to claim equality in the context of the nation-state of Greece and to protect its rights regarding education established by the Treaty of Lausanne. The Federation of Western Thrace Turks in Europe has been playing a leading role in this direction. Their aim is to institute bilingual education at nursery school level, but they also adhere to their right to define themselves as Turks. All this forms a uniform Muslim identity, which, however, has gradually come to be regarded as Turkish.

On the other hand, there is the doubt cast on the idea that Muslim and Turkish identities are one and the same. The Greek state and the municipality of Komotini support this opening for multiculturalism and have instituted a 'food event'. The theoretical approach employed by Yiakoumaki in her doctoral dissertation is remarkable. The relationship between Greece and the European Union reinforces positive feelings on the part of the Greeks. Such sentiments 
stand in opposition to Herzfeld's cultural intimacy. Yiakoumaki (2003: 105) defines this new view held by Greeks as 'cultural autarky', that is, a trope in nationalist discourse, which through the affirmation of cultural 'possession' becomes a powerful affirmation of national existence.

All these new concepts have consequently flowed into the perception of the Greek-Turkish border. However, this process is ill-focussed and tends to the regressive, depending on the current status of relationships between Greece and Turkey. In addition, the meaning borne by the border is connected with some other, mainly economic factors. This was made clear by the events in the northern part of the Evros region in 1990. At that time most of the inhabitants would go across the border at the village of Kastanies, in the northern part of the region, to do their shopping in Adrianoupolis (Edirne). This deprived local shops of income vital to their survival. The situation raised the question as to how the border functioned and whether it in fact protected Greeks' interests. Inevitably, this public discussion drew on a pre-existing view of the border, infused with particular local meanings.

Clearly, themes relating to representations of the border are perplexing and contradictory. Some Greek citizens pride themselves on holding European citizenship, a feature, in their opinion, which automatically makes them superior to those who live beyond the eastern bank of the River Evros. Such persons managed for some years to convince authorities to impose control on the Greek citizens passing through the Kastanies customs post to enter Turkey. It must also be said that those making such demands stress the risk of economic decline in the northern Evros region, because of uncontrolled access to Turkey and because of the subsequent flow of capital into the Edirne (Adrianoupolis) market (Prokkola 2008: 658).

It is clear that, when the border is endowed with such meanings, the concept has moved away from its original sense. The meaning now assigned to the border does not draw attention to a traditional representation of the border as an indicator of national territory. Our example above throws light on a new perception of the border, which is now considered to demarcate an economic zone necessary for the survival of a community. This conception of the border, although it indeed dominates the discourse, has never actually moved into the foreground.

In my view, this concept of the border has caused all the current public discourse over the frachtis over recent months to cohere. What differentiates it from the previously prevailing conception is how the concept of liminal space is used. The residents of the northern Evros region regard the area as liminal (Turner 1967: 93-100) and thus exposed to the danger of losing its economic well-being, which may prove disadvantageous for the Greek-Turkish border 
balance. Later, as part of a wider discussion on the European perspective of Turkey, the liminality was expanded to include all of Thrace. This was now regarded as facing the danger of inundation by Muslims from Turkey, a situation capable of changing the composition of the population. There is a permanent and unchanging thread that runs through all similar narratives on the border liminality. It is often interconnected with what happens on the eastern bank of the River Evros. The existence of the border guarantees the safety of liminal space ${ }^{5}$. Thus strict surveillance of borders is regarded as a necessary condition both for maintaining the current ethnic composition of the population and, therefore, for maintaining the territorial integrity of the Greek state. Furthermore, the prospect of the free movement of labour from Turkey to Greece supplied material for private and public discourses over the decade 2000-2010, when Turkey was seeking entrance to the European Union. This possibility was regarded as a threat to the economy both of the area and of Greece as a whole, since it was thought that it would trigger seasonal transnational migration of cheap labour from Turkey to Greece, which would lead to Greeks' unemployment and the closure of Greek businesses.

In early 2011, this discussion moved from being a peripheral issue to becoming a matter for national debate. Immigrants, mainly from Asia and Africa, were entering Greece via the land section of the Greek-Turkish border in the northern Evros region, a fact that set off a public debate on law and order, migration, unemployment, the ethnic composition of the Greek population, and, above all, on the concept of the nation-state. Despite the importance of this, I intend to remain focussed on how the border is linked to the concept of liminal space. So in the case of illegal immigrants (lathrometanastes being the term used in Greek public discourse, despite the disapproval of some of the participants in this discussion), liminality is transmitted to southern Greece.

It is interesting that the majority of Greeks, despite being adherents of a wide range of political parties, considered that the dam, the frachtis, was necessary, in order to avoid the expansion of liminal space in nationwide terms. The crucial point in the maintenance of this attitude was the involvement of the European Union in the whole process, a fact that mitigated the national burden of guilt by shifting the responsibility for the entire issue to the European agenda.

The matter of the borders is to be set in a broader context. An increasingly large number of migrants from the countries of Asia and Africa, suffering from serious financial and political problems, are seeking a way out in Western Europe from hunger and the danger of genocide. They attempt to reach Europe via Greece, the first country of the European Union on their way.

Transnational migration has given a new meaning to the borders between Greece and illegal immigrants who cross either the land section of the Greek- 
Turkish border or the River Evros. This flow of migrants from the Evros area has made the matter of transnational migration a basic problem for Greece, with tensions increasing in the wake of the economic crisis in Greece in 2010. The increasing influence of illegal migrants and the inability of the Greek state to handle the matter in a humane fashion and safely for all have led to the strengthening of extreme rightwing views and spread of racist ideas. This has occasionally been attributed to Turkey, due to the suspicion that has been cultivated that Turkey is responsible for increasing the flow of illegal migrants to Greece, in order to dispose of them.

The Greek-Turkish borders on the Evros, and the inability of Greece to prevent migrants from crossing the borders have become the symbols of a 'conspiracy'. This motif repeats what both the private discourse and the narrative discourse of folk culture have expressed in the past regarding the danger and certainty that Thrace will fall into the hands of Turkey.

\section{GREEK-TURKISH BORDERS AND INVISIBLE BORDERS IN THRACE}

Another dimension to the question of how borders are defined lies in the question of how national borders are associated with ethnic borders, the so-called 'invisible' borders. The ambiguity that arises from this acquired a new lease of life at the end of the 20th and in the early years of the 21st century. For Greece, during this period it was a political priority to deepen and reinforce its position within the European Union. This, however, had various, and inconsistent, impacts on how boundaries are represented. In other words, the increasing integration of Greece into the European Union led to the questioning of the inflexible manner in which, at a national level, both visible, national, and invisible, ethnic, boundaries were comprehended (Fisher Onar \& Özgüneş 2010: 122-123). The old world had collapsed and international relationships had completely changed. During this period, the European Union focused clearly and powerfully on human rights, on the rights of minorities, and on religious freedom (Pollis 1992: 177). This led to the redefinition of the concept of borders, which occurred where this did not create confusion at the level of existing national borders. On the one hand, the European context made borders more flexible, in that they now functioned as a means of communication. On the other, this new state of affairs blurred borders, reorganised the lives of the inhabitants and impacted on their contact with those across the borders. Thus the main feature that characterises ethnic borders in a context of reversed direction is that representations of such borders become more aggressive and conflict-oriented. 
In my view, the Pomaks (Tsibiridou 2000), a Slavonic-speaking ethnic group within the Muslim minority in Thrace, which was recognised by the Treaty of Lausanne in 1923, exemplify this phenomenon. The Muslim minority in western Thrace consists of three different ethnic groups (Turks, Pomaks, and Gypsies), the total number being, according to the Greek census of 2011, 116,000 (Christidis 1996: 136) $)^{6}$. Of course, estimates of the numbers of the Muslim population in Thrace depend on the aim of the demographic record in question (Aarbakke 2000: 35-40). The Muslim minority, as they were termed in accord with the Treaty of Lausanne of 1923, which laid down the borders between Greece and Turkey in their final form and which was signed after the military defeat of the Greeks in Asia Minor, was excepted from the exchange of Muslims and Christians who lived in Greece and Turkey respectively (Yildirim 2006: 45).

The Pomaks used to live, as many of them still do, in the mountains above Xanthi, one of the three prefectures of Thrace. ${ }^{7}$ Their chief source of income was the cultivation of tobacco, which gradually decreased, so that they were no longer able to support their families (Vernier 1981: 122-142). Thus after the Second World War some of them migrated to Athens within Greece and to Belgium (Madianou 2005: 527), a few shipped as members of the crew on cargo ships, whilst many of them moved down from the mountains either to the villages on the plain or to the town of Xanthi, where they married partners of Turkish origin. ${ }^{8}$ Their children were enrolled in minority schools. Turkey was responsible for these schools and provided teachers to teach the Turkish language and history. Furthermore, "from the early 1950s until 1967, the Greek state actively supported the linguistic Turkification of the local Muslim population, through compulsory minority education" (Antoniou 2005: 82).

The Pomaks are an exceptionally interesting example, if one wishes to broaden the link between external and internal borders, which are frequently not so invisible. Their own area was delimited by bares, as the Greek word is, that is, checkpoints, which controlled the flow of people entering the principal area occupied by the Pomaks (Markou 2010: 103). The presence of bares as a material border within a nation-state made clear the disadvantaged status of the Pomaks as an ethnic group. The bares identified the whole area with liminality and danger and was regarded as a polluted geography.

Unavoidably, then, an understanding of the identity of the Pomaks and of their position in the Muslim minority of Thrace can be gained when one applies Gramsci's concept of hegemony. This perspective "seems applicable to relations between Pomaks and Turks as well as to those between Pomaks and Greeks, where Pomaks are subordinated in both cases" (Demetriou 2004: 115). Tsibiridou uses the concept of the politics of place, to deal with the creation of sectioned-off areas in Thrace, divided into locations where "the lower ranges 
of society are regarded as possessing the exotic features of natives" (Tsibiridou 2005). She also uses it to deal with the role of the Turkish elite in the formation of these areas. Such ethnic areas are ranked hierarchically, depending on who is seen as the stronger party. In the past, however, the view focused more on the Muslim minority and its division, in relation to the Christian majority. In Western Thrace, in the view of the public discourse of the Greek administration that legitimised its arguments by reference to the Treaty of Lausanne, there was one landscape divided up into the world of Christians and the world of Muslims. The Pomaks were invisible, thanks to their geographical isolation, but also by reason of the indifference of the Greek state towards them. The Greek state had done nothing to improve standards of living or promote development in the area.

This is the result of the Treaty of Lausanne, which indeed imposed an institutionalised relationship with the Turkish state, nominated as a national centre for the Muslims (Troumbeta 2001: 33). Thus the Greek-Turkish borders on the Evros influenced the formation of internal borders between Muslims and Christians in western Thrace, which made no allowance for any internal differences within the minority itself. This is obvious in the fashion in which the Pomaks were defined. Poulton (1997: 84) labels them as Islamicised Slavs. The alternative and indiscriminating labels 'Muslim' and 'Turk' in the pre-war period did not cause tension. However, in the post-war period, "the way the minority was named became of crucial importance" (Tsitselikis 2007: 7). The Turkification of the Pomaks occurred after the Second World War, particularly during the 1970s, when a transnational Turkish identity evolved (Karakasidou 1995). This attracted the Pomaks and guaranteed their rights as citizens of the Greek state that had marginalised them. In addition, the Greek state was positively disposed to the Turkification of the Pomaks during the post-war period, given that they inhabited an area on the Greek-Bulgarian borders deemed 'dangerous'. The Bulgarians were at the time regarded as the enemy and the fear that Bulgaria had not relinquished its aim of altering the Greek-Bulgarian borders by demanding part of the Greek territory impacted upon the internal borders of the Pomaks. The gradual Turkification of the Pomaks was encouraged and the impression was given that the Pomak minority was homogeneous. Furthermore, the process of making a nation of the Muslim minority created an arena of conflict for Greece and Turkey. It was also an area in which origin myths evolved, so that they were absorbed into Greek or Turkish narratives. For the Greeks, the Pomaks were the descendants of the soldiers of Alexander the Great who had converted to Islam, whilst for the Turks the Pomaks were ancestors of Turks (Smith 1999: 57-95; Troumbeta 2001: 83). 
The issue of the identity of the Pomaks became an important national matter for Greece and Turkey, which attempted to put the term 'transnational Turkish identity' in clear form. For scholars, the identity of the Pomaks and the threepronged relationship among Greece, the Muslim minority, and Turkey formed an irresistible topic for research on the processes behind the formation of identities.

In the 1990s, Greek authorities reviewed their policy towards the Muslim minority in general and focused on the Pomaks in particular. In the mid-1990s, the Greek authorities changed the situation in Pomak areas, firstly by abolishing the bares, and secondly by introducing legislation to give all Muslims easier access to Greek universities. This approach was impossible until the 1990s, because of the educational conditions for the minority. After this legislation was passed, Muslims began to apply to Greek universities. All these changes were due to the appearance of human rights as a fundamental principle of the European Union and of other international bodies, such as the Council of Europe and the International Court of Human Rights (Aarbakke 2000). This became particularly the case during the 1990s and after the Greek state was obliged, as a member of the European Union, to adopt these new texts as part of its body of law.

The new European and international environment favours the expression of demands and of political identities. This arrangement makes clear the fluidity of the identity of the Pomaks in western Thrace. As a starting point for the broadening of the fluidity of their identity, we have the view, or rather, received opinion, that the life of an identity is dependent, to a great extent, upon its ability to offer protection, social status, and economic benefits for the members of a group (Eminov 2007: 1). For the Pomaks, Greece was to be identified with insecurity, poverty, lack of opportunities for social mobility, and the road barriers that symbolised all of this (Tsibiridou 1999: 163-182). As an ethnic group, they had a body of common experience that one would expect, which compelled them to adopt strategies of survival for dealing with their social environment, and of submission to whomever happened to exercise power. This occurred in the Bulgarian invasion during the Second World War (Demetriou 2004: 101). Thus Poulton's term for the Pomaks, 'Islamicised Slavs', ignores historical circumstances and fails to regard identities as malleable, which can be reformulated, manipulated, and changed. In fact, he regards it as fixed essence. In other words, both states, Greek and Turkey, attempted to show that Pomak identity was primordial, remaining indifferent to the fact that men, at a local level, choose their identity. The Pomaks were influenced by their experiences and views, and by their relations with the central administration or with other neighbouring ethnic groups (Bringa 1993: 70). The public discourse of both states, Greece and Turkey, clashes at the level of internal borders. Turkey 
attempts to legitimise the existence of the internal border in Greece, which has facilitated its function as a national centre for the Muslim, and so Turkish, minority. Greece attempts, unofficially, to link the Pomaks with a Greek descent, which would then cast doubt on their identity.

These two policies have caused cracks in the type of identity chosen by the Pomaks. A fair number have chosen a Turkish identity. This Turkish identity is particularly strong among Pomak academics and those ambitious to enter political life, the local administration, or to hold other positions.

Many Pomak scholars and intellectuals became members of the Turkish Union of Xanthi. A court case was fought over the name of the Union (Kyriakou 2009: 7), as to whether it should be the 'Muslim Union' or the 'Turkish Union', and the insistence of the members of the minority on the adjective 'Turkish' showed that Pomak scholars and intellectuals had been Turkified (Tsitselikis 2007: 8). The closer Greece was tied to the European Union, the more the minority demands for ethnic self-ascription increased. The Turkish Union of Xanthi is the most characteristic example of how the weakening of strict national borders is not necessarily correlated to any tendencies influencing ethnic boundaries within the nation-state. To sustain a symbolic issue related to how a minority is named, a fact that does not take into account social realities, turns a political matter into a human rights problem (Markou 2003: 43-55). That is, to change the name of a minority from 'Muslim' to 'Turkish' has a symbolic value only. In other words, this argument deals with such a process in terms of only superficial change. However, the renaming process involves borders and representations of otherness both inside and outside the Muslim minority. According to Bourdieu, all symbolic strategies are used by agents to "impose their vision of the division of the social world" (Bourdieu 1997 [1991]: 239).

Thus the predominance of the adjective 'Turkish' over 'Muslim' in how cultural associations and other societies define themselves could perhaps be regarded as a shifting of the border, in the sense that the inter-ethnic borders within the Muslim minority have lost their symbolic value as an emblem of differentiation. Instead, the use of the adjective 'Turkish' implies that the minority discourse illuminates the borderline between Christians and Muslims. The most important aspect lies in the change of the adjective. Thus the border has now been drawn between Greeks and Turks. In any case, Pomakness does not have any independent existence. It is a slippery identity, an area that is open to any expansion in relations of power, subordination, and national policies (Demetriou 2004: 100). This is clear in the most obvious fashion in the elections for the local administration and for the Greek parliament. The case of Gulbeyaz Karahasan is typical. She was a PASOK (Pan-Hellenic Socialist Movement Party) candidate for the 'super-prefecture' that included the pre- 
fectures of Drama, Kavala, and Xanthi, and a member of the Muslim minority descended from the Pomak villages around Xanthi.

The daughter of Muslim farmers, she was born in the village of Glavki, in the municipality of Myki, 28 years ago. The inhabitants of the village are $100 \%$ Muslim. Her father was a farmer and carpenter, in order to bring up three daughters. (Giannaka 2006)

This extract from an article repeatedly stresses her religious identity, which accords with the public discourse of the Greek state regarding this identity. Yet her village is one of the Pomak villages. Her candidacy provoked controversy and various extreme reactions. The decision of PASOK was regarded as an attempt to force to the surface the question of the Pomaks, while ignoring Turkey as a national centre for the Pomaks. Some political circles in Athens stressed that the Pomak origin of Ms Karahasan drew her away from the unchanging plans of Ankara and the Turkish Consulate (Kalliagopoulos 2006). In other words, the selection of Karahasan as a candidate showed how complicated the issue of the Pomaks was. Their identity thus became an arena for conflict, which was occasionally difficult to interpret for the uninitiated. The aim was control of the Pomaks and the matter of whether the fault line in Thrace would continue to divide the inhabitants into Christians and Muslims or would bring out new lines of division among the ethnic minorities of Thrace. Furthermore, the Karahasan affair revealed the existence of yet another important centre of power in the Pomak minority. This is the Turkish Minority of Western Thrace Advisory Committee, since Karahasan's candidacy required approval by the members of the Turkish minority. This set off a heated debate, since it was considered to be by extension the policy of the leaders of the minority and of Turkey, whose aim was to control the members of the minority that wielded power.

In addition to this, the candidacy of Karahasan and her life form a frame of reference for whatever is said to the effect that Pomak identity is fluid and labile. To deal with this dimension, Demetriou employs the example of two young Pomaks, Selim and Osman, who chose identities different from each other. The first "could be a Pomac Turk" and the second "could be considered a Pomak Greek" (Demetriou 2004: 101).

The case of Karahasan shows that identity is a more complicated and multilevel matter, to the point that Selim and Osman exist in the same person, as is the case with Karahasan and many other members of the minority of Pomak origin. The fluidity and multiplicity of their identity allow the Pomaks to adapt to various circumstances and use them to their advantage (Eminov 2007: 5). Karahasan is a member of the Turkish Union of Xanthi, of which the greater part of Pomak intellectuals who have studied in Turkey are members. 
Various ethnic groups usually adopt the identity of the dominant group when they share the same religion. This process facilitates survival strategies and social upward mobility. In the case of the Muslim minority of western Thrace, the ambitions of young academics and intellectuals for professional, social, and political progress are to be achieved only through the agency and in the context of the minority, which functions as another form of power, an alternative to the indifferent Greek state. "Turkishness is a hegemonic minority identity discourse" (Demetriou 2004: 101). Consequently, the Pomaks, after Turkish education at primary and secondary level and training at Turkish universities, have no choice other than to join 'Turkish' associations to indicate that they are Turkish and to map out their future, as their starting point, with the Muslim minority that struggles for recognition as Turkish. Besides, the elite of the minority disapprove of the use of the ethnic term 'Pomak', as it might revive the old inter-ethnic borderline within the minority. Thus the Muslim or Turkish Union of Xanthi, as well as all the other cultural and professional associations for members of the Muslim minority in Greek Thrace, functions as a symbolic space, in which "a play of differences" (Gupta \& Ferguson 1997: 17) and identities are shaped.

It was inevitable that Karahasan joined the Turkish Union, since public discourse regarding identity can develop "within seemingly solid classificatory boundaries" (Demetriou 2004: 100). This view is reinforced by a consideration of the reaction on the part of various elements in Greece, such as the media, various associations, and websites. These brought into the living rooms of Greek households across the country the matter of the Muslim minority and its ethnic groups. If we leave aside the various conspiracy theories that were articulated, the participation of Karahasan made clear her intention to move into a new area of activity, where her Pomak descent has great importance for the understanding of the fluidity of her identity, even if she declares herself to be Turkish. This is indeed a case of doubt being cast upon the solid classificatory boundaries in the definition of identities.

\section{POMAK PUBLIC DISCOURSE}

During the 2000s the public discourse of Pomaks who wished to be recognised as Greeks was formulated. The Pomak Cultural Association of Xanthi, established in 2007, returned to the issue of Pomak identity and the inter-ethnic borderline. The members of the association wrote in their declaration: 
Most of our fellow citizens, either because of ignorance or intention, persist in identifying Islam with the Turks. We are Pomaks, deeply rooted in the land of Thrace, and our destiny is unbreakably connected with that of this land. We want to live in this area, preserving our language, belief, and our ancestors' customs, in order to hand them down to our children. ${ }^{9}$

This extract is clear. It displays the opinion of those who have composed it that there is an inter-ethnic borderline within the Muslim minority, whose existence is questioned by minority authorities and even by a great number of Pomaks who have chosen the Turkish identity. Light is cast on all the discourse over the name of the Pomak ethnic group by the view of Barth, who maintains that what is important in such cases is the "ethnic boundary that defines the group rather than the cultural stuff that it encloses" (Barth 1969: 15). The Pomaks choose a minority consciousness, albeit rejecting any attempt to define them as members of the Turkish minority. Their association, the newspaper Natprash, and the website zaglisa.gr, are expressions of the other element that chooses the Greek identity, in that they accept the mythological story regarding their descent from the soldiers of Alexander the Great. Journalist Karahotza, one of the leaders of the group who wish to maintain their Pomak identity, states, "They simply want to be known as Pomaks, because this is a fact, and want to proclaim their Greek consciousness" (Karahotza 2009). This is the first time that a demand for the Pomak identity has appeared, along with terms defining the identity, and the myth of descent that has been formulated by a group of Greek academics (Seyppel 1989: 42). Doubt is thereby cast on the internal borders of the Muslim minority. This group of Pomaks are now demanding education via use of the Greek language and have sent a letter to the Prime Minister. ${ }^{10}$ This action directly casts doubt on the validity of the Treaty of Lausanne, that is, on the acceptance of Turkey as their national centre.

The whole attitude of minority authorities and minority elite towards the possibility of restoring the internal border is condensed in a public debate that occurred in the village of Echinos, which was the capital of the Pomakochoria area in the Xanthi Mountains. Riots broke out, protests being lodged about an actress who insulted the beliefs of the local inhabitants by entering a mosque in a supposedly immodest dress. I cannot myself say whether the person in question did, or did not, behave in this fashion. Even if the matter had its origins in such unacceptable behaviour, I have the impression that the main point lies in how this case then developed. It was an opportunity for minority authorities and those who wished to regard the minority as a Turkish ethnic group to formulate the matter in a collective manner. Their reaction managed to end up, functioning as a ritual expression, making clear their desire that it be taken for granted that there are no Pomaks and that no intra-ethnic border exists. 
In general, the more Greece comes to adopt European legislation, the more the Muslim minority - at least minority authorities and elites - increase their demands for self-definition, which means allowing their cultural associations to be renamed. There is no doubt that this situation arises from a long-term policy implemented by the Greek state over the second half of the 20th century. Thus over all this period there was complete correspondence between an inflexible representation of the national borderline and the marginalised minority. Both of them occupied a liminal space regarded as polluted and dangerous. The newly-established European environment put the spotlight on the minority as it drew attention to the new state of affairs. A number of Pomaks have ended up defining themselves as Turks, after the process of Turkification that occurred during the period when the Greek authorities thrust the Pomaks to the margins of the state, believing this to be the only solution. The state regarded the members of this minority as liminal, a fact that justified their marginalisation, and the lower status accorded them as citizens of the Greek state. What emerges from the public debate over where the ethnic borderlines of the Muslim minority in Thrace are to be drawn consists of two main issues. The first one relates to a ritual held in the area of the Alevi Pomaks, on the Sitsek plateau, each August (Tsibiridou 2005: 79). This is a summer feast, which in recent decades has been transformed into a ritual for sanctifying the minority unification as a whole and at the same time for reaffirming the fact that self-definition as Turks prevails over particular ethnic names, i.e. Pomaks and Roma. The main activities of this rite consist of wrestling contests on the one hand and of the gathering of politicians and delegates of cultural and other groups on the other. Everything that occurs at this feast, official or otherwise, including the plateau itself, the participants, the wrestling, the symbols, the music, the flags, the discussions, the politicians and their speeches, constitutes the essence of this discourse, which focuses on the practice and the objectification of a sense of belonging.

Wrestlers from Turkey, mostly from Edirne (Adrianoupolis) area, come and compete. However, the most important aspects of the event lie in how this rite is contextualised by its organisers.

The Turks of western Thrace revived on the Sitsek Plateau (Chilia being the name in Greek) the traditional wrestling organised by our people living in the Evros region. Each year visitors from our mother country came over. The Turks who arrived at the Sitsek Plateau from across western Thrace watched traditional wrestling and the dance groups of the Turkish Union of Xanthi, the Union of Komotini Turkish Youth and the Association of the Southern Evros and Goniko. ${ }^{11}$ 
The website emphasises the identity of those who participated in the festival. Among them were the Consul General of Turkey in Komotini, Thrace, the mufti (Muslim expert on the law of Koran), mayors, and delegates of associations and societies. At the same time it stresses the absence of 'Greeks' and Muslims as members of Parliament in Greece.

This text makes very clear what is taking place on the Sitsek Plateau. This article upbraids Muslim politicians who avoided taking part in this annual event, and attributes their behaviour to the possibility that perhaps they took it for just a rite. This makes it clear how this event is contextualised by the organisers. Obviously the controversial point is not the ritual dimension of the whole meeting. This is unquestionable, however one regards the event. Thus the main point of this public discourse is to be associated with what it focuses on. In other words, we appear to have conflicting views concerning the aim of the ritual. The rite in the past used to be a ritual to encourage reproduction for the Bektashi religious community in Thrace. Gradually this content was transmuted and different material was introduced. It provided the appropriate formula for reproducing the new collectivity and identity. Consequently, the main point of these events has been to reaffirm that the only border that exists is the one between Turks and Greeks.

\section{CONCLUSIONS}

Borders epitomise historical routes, national ambitions, conflicts and rivalries, cultural similarities and dissimilarities. All these are expressed in a national or ethnic mythology which, if illuminated in an appropriate way, can offer much regarding representations, thoughts, emotions, and the aims of neighbouring populations.

The border between Greece and Turkey, after the two nation-states had been established, and especially during the 20 th century, imposed a policy that brought about a spatial reorganisation of the Greek territory, which involved the division and marginalisation of Thrace. This was responsible for its stigmatisation as a 'polluted area', so to speak. The absorption of Greece into the European Union changed this view of the border with Turkey, which was under complete control even as late as the beginning of the 1990s. Closer relations between Greece and the European Union influenced the representation of the border and improved relations with Turkey. This was reflected in the relations of both Greece and Turkey with the Muslim minority of Thrace.

Although the reorganisation of space continues, increasing transnational migration from Asia and Africa, particularly with the background of the finan- 
cial crisis that hit Greece at the end of the 2000s, this process is responsible for bringing about a change in the meaning of the borders and of Thrace itself. The erection of the fence that functions as a wall on the Greek-Turkish border brings out into the open the need to redefine the terms of discussion on concepts such as borders, identity, Europe, and minorities. Above all, the fence is a challenge to reorder Greek-Turkish relations and the relationships between the visible border, i.e. the Evros region, and the unseen borders, i.e. the ethnic groups of the Muslim minority of Thrace.

\section{NOTES}

1 The word 'septemvriana' refers to everything the Turks did against the Greek minority in Istanbul in September 1955. This included destruction and burning of 1,004 houses, 4,348 shops, 27 pharmacies and laboratories, 21 factories, 110 restaurants, a number of cafes and hotels, 73 churches, 26 schools, 5 sports clubs, and 2 cemeteries (Alexandris 1992: 259).

2 One of the songs which constitute the circle of the songs of Constantinople/Istanbul, depicting the fall of the city under the power of the Ottomans in 1453 and encouraging Greeks that sometime in the future the city will become Greek again.

${ }^{3}$ Herzfeld called disemia such a fundamental concept (Herzfeld 1989: 95-122).

${ }^{4}$ Here we have a practical application of the concept of the 'politics of place' (Appadurai 1986).

5 The phrase 'liminal space' recalls the expression 'territorial space' (Van Gennep 1965: 15).

6 "This profoundly religious minority of 100,000 - composed of approximately 70,000 Muslims of Turkish ethnic origin, 35,000 Pomaks (slavophone Muslims) and 5000 Muslims of Romany ethnic origin" (Oran 2003: 98).

7 The area of Pomaks is located in the Rodope Range, which is the border with Bulgaria, where over 250,000 Pomaks, called Bulgarian Mohammedans, live (Poulton 1991).

8 The same occurs in the case of the Pomaks who migrate to Komotini, the regional capital of western Thrace (Demetriou 2004: 101).

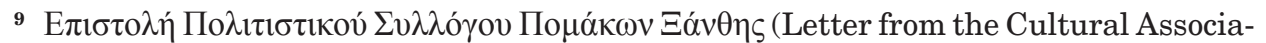
tion of Pomaks, prefecture of Xanthi, western Thrace). March 4, 2009. Available at https://voukino.wordpress.com/2009/03/04/pomakoi/, last accessed on October 5, 2015.

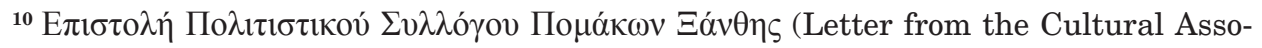

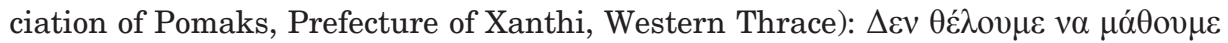

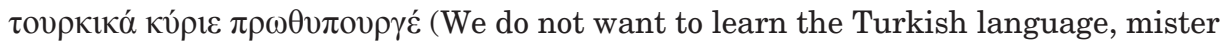
Prime Minister). Available at http://infognomonpolitics.blogspot.com.ee/2010/03/blogpost_6559.html, last accessed on November 6, 2015. 


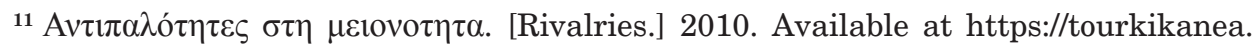
wordpress.com/2010/08/06/secek-2/, last accessed on November 6, 2015.

\section{REFERENCES}

Aarbakke, Vemund 2000. The Muslim Minority of Greek Thrace. Diss. (PhD Thesis). University of Bergen. Unpublished.

Akçam Taner 2004. From Empire to Republic: Turkish Nationalism and the Armenian Genocide. London \& New York: Zed Books.

Alexandris, Alexis 1992. The Greek Minority of Istanbul and Greek-Turkish Relations, 1918-1974. Athens: Centre for Asia Minor Studies.

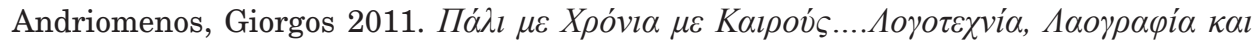

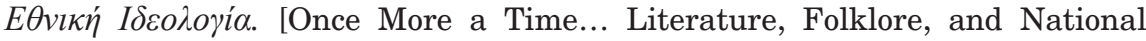
Ideology.] Athens: I. Sideris.

Antoniou, Dimitris 2005. Western Thracian Muslims in Athens: From Economic Migration to Religious Organization. Balkanologie, Vol. 9, No. 1-2, pp. 79-101. Available at http://balkanologie.revues.org/579, last accessed on October 6, 2015.

Appadurai, Arjun 1986. Theory in Anthropology: Center and Periphery. Comparative Studies in Society and History, Vol. 28, No. 2, pp. 356-361. http://dx.doi. org/10.1017/S0010417500013906.

Ardener, Edwin 1989. Language, Ethnicity and Population. In: M. Chapman (ed.) The Voice of Prophecy and Other Essays. Oxford: Blackwell, pp. 65-71.

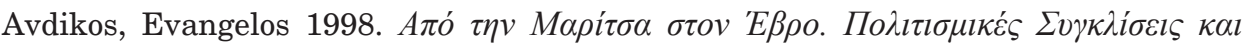

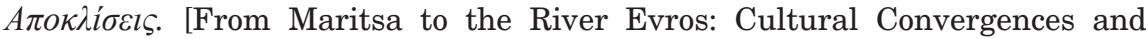
Divergences.] Alexandroupolis: Municipality of Tyhero.

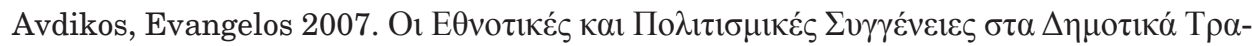

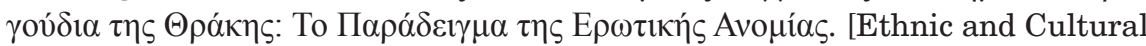
Affinities and Contrasts in the Folk Songs of Greece: The Example of Erotic

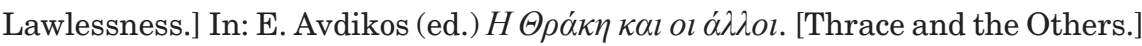
Athens: Odysseas, pp. 104-121.

Barth, Fredrik 1969. Introduction. In: F. Barth (ed.) Ethnic Groups and Boundaries: The Social Organization of Culture Difference. London: Allen and Unwin, pp. 9-38.

Bourdieu, Pierre 1997 [1991]. Language and Symbolic Power. Cambridge, UK: Polity Press.

Bringa, Tone R. 1993. Nationality Categories, National Identification and Identity Formation in "Multinational" Bosnia. The Anthropology of East Europe Review, Vol. 11, No. 1-2, pp. 80-89. Available at https://scholarworks.iu.edu/journals/ index.php/aeer/article/view/591, last accessed on October 6, 2015.

Brunnbauer, Ulf 1999. Diverging (Hi-)Stories: The Contested Identity of the Bulgarian Pomaks. Ethnologia Balkanica, Vol. 3, pp. 35-50.

Certeau, Michel de 1980. L'Invention du Quotidien. Paris: UGE.

Cohen, Abner 1974. Two-Dimensional Man: An Essay on the Anthropology of Power and Symbolism in Complex Society. London: Routledge \& Kegan Paul. 
Christidis, Yorgos 1996. The Muslim Minority in Greece. In: Gerd Nonneman \& Tim Niblock \& Bogdan Szajkowski (eds.) Muslim Communities in the New Europe. Berkshire: Ithaca Press, pp. 153-166.

Demetriou, Olga 2004. Prioritizing 'Ethnicities': The Uncertainty of Pomak-ness in the Urban Greek Rhodoppe. Ethnic and Racial Studies, Vol. 27, No.1, pp. 95-119. DOI: 10.1080/0141987032000147959.

Demirözü, Damla 2008. The Greek-Turkish Rapprochement of 1930 and the Repercussions of the Ankara Convention in Turkey. Journal of Islamic Studies, Vol. 19, No. 3, pp. 309-324. DOI:10.1093/jis/etn003.

Ellison, Ralph 1952. Invisible Man. New York: Vintage International.

Eminov, Ali 2007. Social Construction of Identities: Pomaks in Bulgaria. Journal of Ethnopolitics and Minority Issues in Europe, Vol. 2, pp. 1-25. Available at http:// www.isn.ethz.ch/Digital-Library/Publications/Detail/?lang=en\&id=115615, last accessed on October 6, 2015.

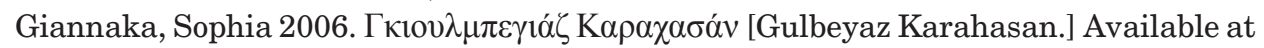
http://www.tovima.gr/politics/article/?aid=173197, last accessed on November 13, 2015.

Gielis, Ruben 2009. Borders Make the Difference: Migrant Transnationalism as a Border Experience. Tijdschrift voor Economische en Sociale Geografie, Vol. 100, No. 5, pp. 598-609. http://dx.doi.org/10.1111/j.1467-9663.2009.00572.x.

Görög-Karady, Veronika 1992. Ethnic Stereotypes and Folklore: The Jew in Hungarian Oral Literature. In: Reimund Kvideland (ed.) Folklore Processed: In Honour of Lauri Honko on his 60th Birthday, 6th March 1992. Helsinki: Suomalaisen Kirjallissuuden Seura, pp. 114-126.

Gupta, Akhil \& Ferguson, James 1997. Culture, Power, Place: Ethnography at the End of an Era. In: A. Gupta and J. Ferguson (eds.) Culture, Power, Place: Explorations in Critical Anthropology. Durham \& London: Duke University Press, pp. 1-29.

Fisher Onar, Nora \& Özgüneş, Meriç 2010. How Deep a Transformation? Europeanization of Greek and Turkish Minority Policies. International Journal on Minority and Group Rights, Vol. 17, No. 1, pp. 111-136. DOI: 10.1163/157181110X12595859 744240.

Herzfeld, Michael 1986. Ours Once More: Folklore, Ideology and the Making of Modern Greece. New York: Pella Publishing Company.

Herzfeld, Michael 1989 [1987]. Anthropology through the Looking-Glass: Critical Ethnography in the Margins of Europe. Cambridge, UK: Cambridge University Press.

Hirschon, Renée 2008. History's Long Shadow: The Lausanne Treaty and Contemporary Greco-Turkish Relations. In: Othon Anastasakis \& Kalypso Nicolaidis \& Kerem Öktem (eds.) In the Long Shadow of Europe: Greeks and Turks in the Era of Postnationalism. Leiden \& Boston: Martinus Nijhoff, pp. 73-94. Available at https://www.anthro.ox.ac.uk/fileadmin/images/staff/Associates/15--history_s_ long_shadow_proofs.pdf, last accessed on October 6, 2015.

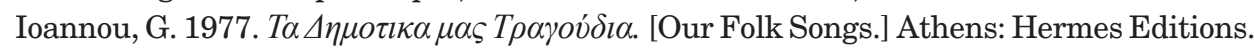




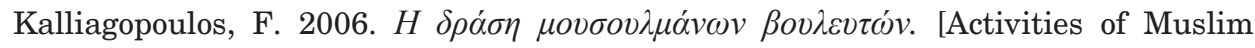
Members of Greek Parliament.] May 13. Available at http://www.kathimerini. gr/250838/article/epikairothta/politikh/h-drash-moysoylmanwn-voyleytwn, last accessed on November 13, 2015.

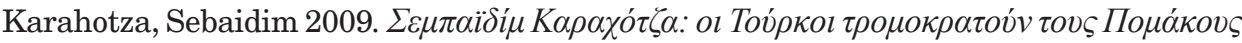

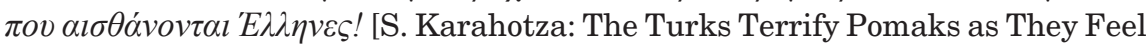
Greeks!] Available at http://proxeneio-stop.org/?s=\%CE\%B1\%CE\%B9\%CF\%83\% $\mathrm{CE} \% \mathrm{~B} 8 \% \mathrm{CE} \% \mathrm{AC} \% \mathrm{CE} \% \mathrm{BD} \% \mathrm{CE} \% \mathrm{BF} \% \mathrm{CE} \% \mathrm{BD} \% \mathrm{CF} \% 84 \% \mathrm{CE} \% \mathrm{~B} 1 \% \mathrm{CE} \% \mathrm{~B} 9++\%$ $\mathrm{CE} \% \mathrm{AD} \% \mathrm{CE} \% \mathrm{BB} \% \mathrm{CE} \% \mathrm{BB} \% \mathrm{CE} \% \mathrm{~B} 7 \% \mathrm{CE} \% \mathrm{BD} \% \mathrm{CE} \% \mathrm{~B} 5 \% \mathrm{CF} \% 82$, last accessed on November 13, 2015.

Karakasidou, Anastasia 1995. Vestiges of the Ottoman Past: Muslims under Siege in Contemporary Greek Thrace. Cultural Survival Quarterly, Vol. 19, No. 2, pp. 71-75. Available at http://www.culturalsurvival.org/publications/culturalsurvival-quarterly/192-summer-1995-nationalism-eastern-europe, last accessed on October 6, 2015.

Kyriakou, Nikolas 2009. Minority Participation in Public Life: The Case of Greece. Journal on Ethnopolitics and Minority Issues in Europe, Vol. 2, pp. 1-18. Available at http://www.isn.ethz.ch/Digital-Library/Publications/Detail/?ots591=0c54e3b31e9c-be1e-2c24-a6a8c7060233\&lng=en\&id=115480, last accessed on November 20, 2015.

Laube, Lena \& Roos, Christof 2010. A "Border for the People"? Narratives on Changing Eastern Borders in Finland and Austria. Journal of Borderlands Studies, Vol. 25, Nos. 3-4, pp. 31-49. DOI:10.1080/08865655.2010.9695770.

Levi-Strauss, Claude 1966. The Savage Mind. London: Weidenfeld and Nicholson.

Linke, Uli 1990. Folklore, Anthropology, and the Government of Social Life. Comparative Studies in Society and History, Vol. 32, No. 1, pp. 117-148. DOI: http://dx.doi. org/10.1017/S0010417500016352.

Madianou, Mirca 2005. Contested Communicative Spaces: Rethinking Identities, Boundaries and the Role of the Media among Turkish Speakers in Greece. Journal of Ethnic and Migration Studies, Vol. 31, No. 3, pp. 521-541. http:// dx.doi.org/10.1080/13691830500058760.

Markou, Katerina 2003. La Terminologie Adoptée à propos des Musulmans de Thrace Grecque. Mésogeios, Vol. 20-21, pp. 43-55.

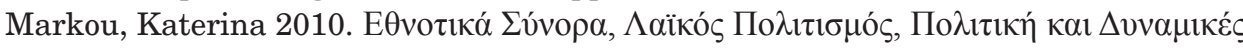

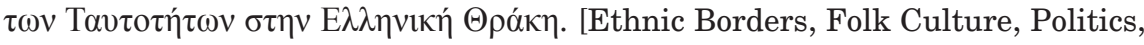

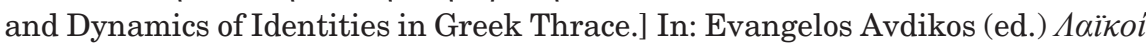

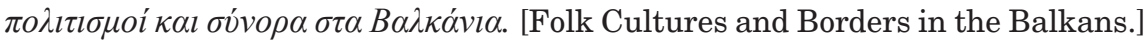
Athens: Pedio, pp. 97-118.

Memisoglu, Fulya 2007. The European Union's Minority Rights Policy and Its Impact on the Development of Minority Rights Protection in Greece. Available at http://www. lse.ac.uk/europeanInstitute/research/hellenicObservatory/pdf/3rd_Symposium/ PAPERS/MEMISOGLOU_FULYA.pdf, last accessed on September 23, 2015. 
Narayan, Kirin 1993. How Native Is a "Native" Anthropologist? American Anthropologist, Vol. 95, No. 3, pp. 671-686. http://dx.doi.org/10.1525/aa.1993.95.3.02a00070.

Ngunjiri, Faith Wambura \& Hernandez, Kathy-Ann C. \& Chang, Heewon 2010. Living Autoethnography: Connecting Life and Research. Journal of Research Practice, Vol. 6, No. 1, pp. 1-17. Available at http://jrp.icaap.org/index.php/jrp/article/ view/241, last accessed on September 22, 2015.

Oran, Baskin 2003. The Story of Those Who Stayed: Lessons from Articles 1 and 2 of the 1923 Convention. In: Renée Hirschon (ed.) Crossing the Aegean: An Appraisal of the 1923 Compulsory Population Exchange between Greece and Turkey. Oxford: Berghahn, pp. 97-116.

Paredes, Américo 1995 [1993]. The Problem of Identity in a Changing Culture: Popular Expressions of Culture Conflict along the Lower Rio Grande Border. In: R. Bauman (ed.) Folklore and Culture on the Texas-Mexican Border. Austin: University of Texas Press, pp. 19-48.

Politis, N. G. 1918. Croyances Populaires sur le Retablissement de la Nation Hellenique. Revue de Gréce, Vol. 1, No. 1, pp. 151-170.

Pollis, Adamantia 1992. Greek National Identity: Religious Minorities, Rights, and European Norms. Journal of Modern Greek Studies, Vol. 10, No. 2, pp. 171-196. http://dx.doi.org/10.1353/mgs.2010.0193.

Poulton, Hugh 1991. The Balkans: Minorities and States in Conflict. London: Minority Rights Publications.

Poulton, Hugh 1997. Changing Notions of National Identity among Muslims in Thrace and Macedonia: Turks, Pomaks and Roma. In: H. Poulton \& S. Taji-Farouki (eds.) Muslim Identity and the Balkan State. London: Hurst and Company, pp. 82-102.

Prokkola, Eeva-Kaisa 2008. Border Narratives at Work: Theatrical Smuggling and the Politics of Commemoration. Geopolitics, Vol. 13, No. 4, pp. 657-675. http://dx.doi. org/10.1080/14650040802275495.

Rizas, Sotiris 2009. Managing a Conflict between Allies: United States Policy towards Greece and Turkey in Relation to the Aegean Dispute, 1974-76. Cold War in the Aegean. Cold War History, Vol. 9, No. 3, pp. 367-387. DOI:10.1080/14682740802170883.

Smith, Anthony D. 1999. Myths and Memories of the Nation. Oxford: Oxford University Press.

Strüver, Anke 2003. Presenting Representations: On the Analysis of Narratives and Images along the Dutch-German Border. In: E. Berg \& H. Van Houtum (eds.) Routing Borders Between Territories, Discourses and Practices. Aldershot, GB: Ashgate, pp. 161-176.

Seyppel, Tatjana 1989. Pomaks in Northeastern Greece: An Endangered Balkan Population. Journal Muslim Minority Affairs, Vol. 10, No. 1, pp. 41-49. DOI:10.1080/02666958908716100.

Stuckey, Leigh 2009. Narrating the Greco-Turkish Population Exchange: Stories about Belonging and Otherness in the Nation. Diss. (MA Thesis). Duke University, Department of Cultural Anthropology. Available at http://dukespace.lib.duke. edu/dspace/handle/10161/1282, last accessed on October 7, 2015. 
Theodossopoulos, Dimitrios 2006. Introduction: The 'Turks' in the Imagination of the 'Greeks'. South European Society \& Politics, Vol. 11, No. 1, pp. 1-32. DOI:10.1080/13608740500470299.

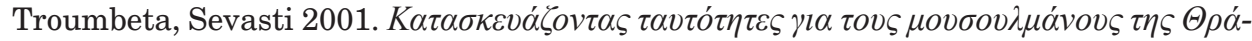
$\kappa \eta \varsigma$. [Constructing Identities for the Muslims in Thrace: The Pomak and Roma Issue.] Athens: Kritiki.

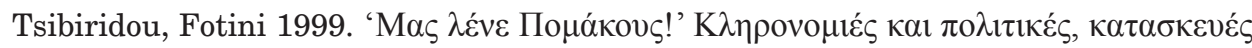

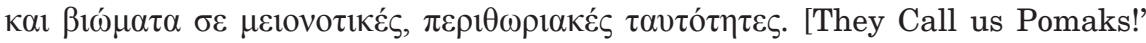
Legacies and Experiences in the Identities of Marginalised Minorities.] Mví $\mu \omega v$ [Mnimon], Vol. 21, pp. 163-182. http://dx.doi.org/10.12681/mnimon.789.

Tsibiridou, Fotini 2000. Les Pomak dans la Thrace Grecque: Discours Ethnique et Practiques Socioculturelles. Paris: L'Harmattan.

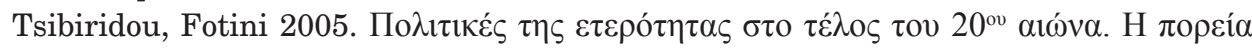

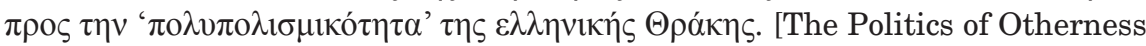
at the End of the 20th Century: The Path towards Multiculturalism in Greek

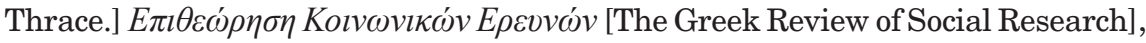
Vol. 118, pp. 59-93.

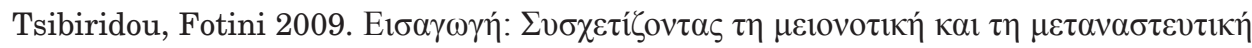
$\varepsilon \mu \pi \varepsilon i p i ́ \alpha$. [Introduction: Linking the Minority and Migrant Experiences.] In: F. Tsi-

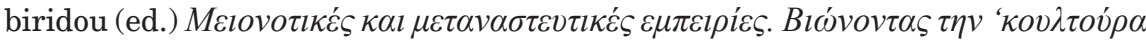

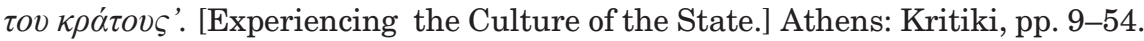

Tsitselikis, Konstantinos 2007. The Pending Modernisation of Islam in Greece: From Millet to Minority Status. Südosteuropa, Vol. 4, pp. 354-372. Available at http://www.ceeol.com/aspx/issuedetails.aspx?issueid=185158aa-f4fa-429e-92b8c2a19dd788ef\&articleid=d1d7f028-5705-4f10-b6f9-890a3effab81\#ad1d7f0285705-4f10-b6f9-890a3effab81, last accessed on October 7, 2015.

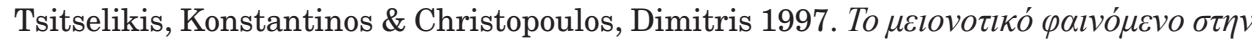
$E \lambda \lambda \alpha \dot{\delta} \alpha$. [The Minority Phenomenon in Greece.] Athens: Kritiki.

Turner, Victor 1967. The Forest of Symbols: Aspects of Ndembu Ritual. Ithaca \& London: Cornel University Press.

Van Gennep, Arnold 1965 [1960]. The Rites of Passage. London: Routledge and Kegan Paul.

Van Houtum, Henk 2005. The Geopolitics of Borders and Boundaries. Geopolitics, Vol. 10, No. 4, pp. 672-679. DOI:10.1080/14650040500318522.

Vernier, Bernard 1981. Représentation Mythique du monde et Domination Masculine chez les Pomaques Grecs. The Greek Review of Social Research: Special Volume, pp. 22-142. Available at http://www.grsr.gr/index.php/ekke/article/view/571/1965, last accessed on October 7, 2015.

Vryonis, Speros 2005. The Mechanism of Catastrophe: The Turkish Pogrom of September 6-7, 1955, and the Destruction of the Greek Community of Istanbul. New York: greekworks.com.

Yiakoumaki, Vassiliki 2003. The Nation as "Acquired Taste": On Greekness, Consumption of Food Heritage, and the Making of the New Europe. Diss. (PhD Thesis), The New School, New York. Unpublished. 
Yildirim, Onur 2006. The 1923 Population Exchange, Refugees and National Historiographies in Greece and Turkey. East European Quarterly, Vol. 40, No. 1, pp. 45-70. Available at http://www.academia.edu/3242406/_Historiography_of_ the_Turco-Greek_Exchange_of_Populations_, last accessed on October 8, 2015.

Zayas, Alfred de 2007. The Istanbul Pogrom of 6-7 September 1955 in the Light of International Law. Genocide Studies and Prevention, Vol. 2, No. 2, pp. 137-154. Available at http://scholarcommons.usf.edu/gsp/vol2/iss2/4/, last accessed on October 6, 2015. 


\title{
WALTER ANDERSON'S LETTERS TO JOAN AMADES: A STUDY OF THE COLLABORATION BETWEEN TWO CONTEMPORARY FOLKLORISTS
}

\author{
Carme Oriol
}

\begin{abstract}
Between 1953 and 1958, Walter Anderson and Joan Amades maintained a frequent correspondence, in which they discussed issues related to the study of folklore. Of these letters, only those written by Walter Anderson - a total of 31 - have been preserved. This article examines the contents of those letters and, consequently, the nature of the collaboration between the two folklorists. In addition to some biographical details, the letters provide first-hand information about the work the folklorists were doing, the publications they exchanged, their participation in folklorist associations and international conferences, etc. However, the letters show, above all, the extent to which Anderson acted as Amades's mentor, especially on issues related to the cataloguing of Catalan folktales a project which was still unfinished when Joan Amades died in 1959, followed by Walter Anderson in 1962, and which was not completed until more recently.
\end{abstract}

Keywords: collected letters, folklore, folktale, history of folklore studies, historical-geographical method, Joan Amades, Walter Anderson

On the 125th anniversary of the birth of Joan Amades

\section{INTRODUCTION}

Walter Anderson was born in Minsk on 10 October 1885 and died in Kiel on 23 August 1962. Anderson's family background meant that he was likely to receive a university education. He studied classical philology at the University of Kazan and later continued his studies at the Department of Germanic and Romance philology at the University of St. Petersburg. Initially his research focused on folktales in classical literature; however, over time his attention increasingly turned towards the study of folklore in its own right. Between 1920 and 1939, he occupied the first Chair of Estonian and Comparative Folklore at the University of Tartu. Between 1940 and 1945, he was professor of folklore at the University of Königsberg and, between 1945 and 1953, at the Univer- 
sity of Kiel, where he remained as a professor emeritus until 1962. In 1950 he spent several months as a visiting scholar at the University of Bloomington (Indiana) along with Professor Stith Thompson (1885-1976). He was renowned for his knowledge of the historic-geographic method, an area in which he made several important theoretical contributions, some of which were not without controversy, such as his Law of Self-Correction and the concept of "Normalform" (Seljamaa 2005: 154). His formidable gift for languages (he had a command of more than 40, in addition to several dialects) enabled him to study folklore from the perspective of the historic-geographic method, which he regarded as a specific scientific method for studying folklore. He made innovative contributions to the study of folklore, such as the experiments he conducted to demonstrate the validity of the Law of Self-Correction (Anderson 1951, 1956), and his research into aspects of contemporary folklore such as chain letters (Anderson 1937) and rumours (Anderson 1925-1926, 1960). His study of rumours titled Die Marspanik in Estland 1921 (Anderson 1925-1926) was one of the first to examine this phenomenon as an element of folklore (Kalmre 2013: 18).

Joan Amades was born in Barcelona on 23 July 1890, and died therein on 17 January 1959. Amades was born into a working-class Barcelonese family and had to work from an early age in the family's antiquarian book business. In 1905 he started to attend courses offered by the Ateneu Enciclopèdic Popular de Barcelona (People's Encyclopaedia Association of Barcelona), an organisation meant to increase education standards among the working classes. Whilst there, he studied languages (French, English, German, and Esperanto) alongside other subjects, and he also participated in excursions into the countryside, aimed at collecting samples of traditional Catalan culture from various villages around Catalonia. Between 1915 and 1926, he collaborated in folklorecollecting projects organised by the Arxiu d'Etnografia i Folklore de Catalunya (Archive of Ethnography and Folklore of Catalonia) (1915-1923), and in the Obra del Cançoner Popular de Catalunya (Popular Song Project of Catalonia) (1922-1935). Although he was largely self-taught, he became one of the most highly respected Catalan folklorists. His most extensive works on Catalan folklore were published during the 1950s and dealt with folktales, traditions, and legends (Amades 1950), songs, proverbs, and riddles (Amades 1951) and customs (Amades 1950-56).

It can be seen from these two short biographies that the two folklorists came from very different backgrounds. Anderson received a university education and was a university lecturer, in short, he was an academic in every sense of the word. In contrast, Amades was self-taught and often expended great personal effort to compensate for his limited knowledge of scientific methods. Nevertheless, the two men shared two fundamental characteristics: a great collaborative spirit and an enormous capacity for work. 


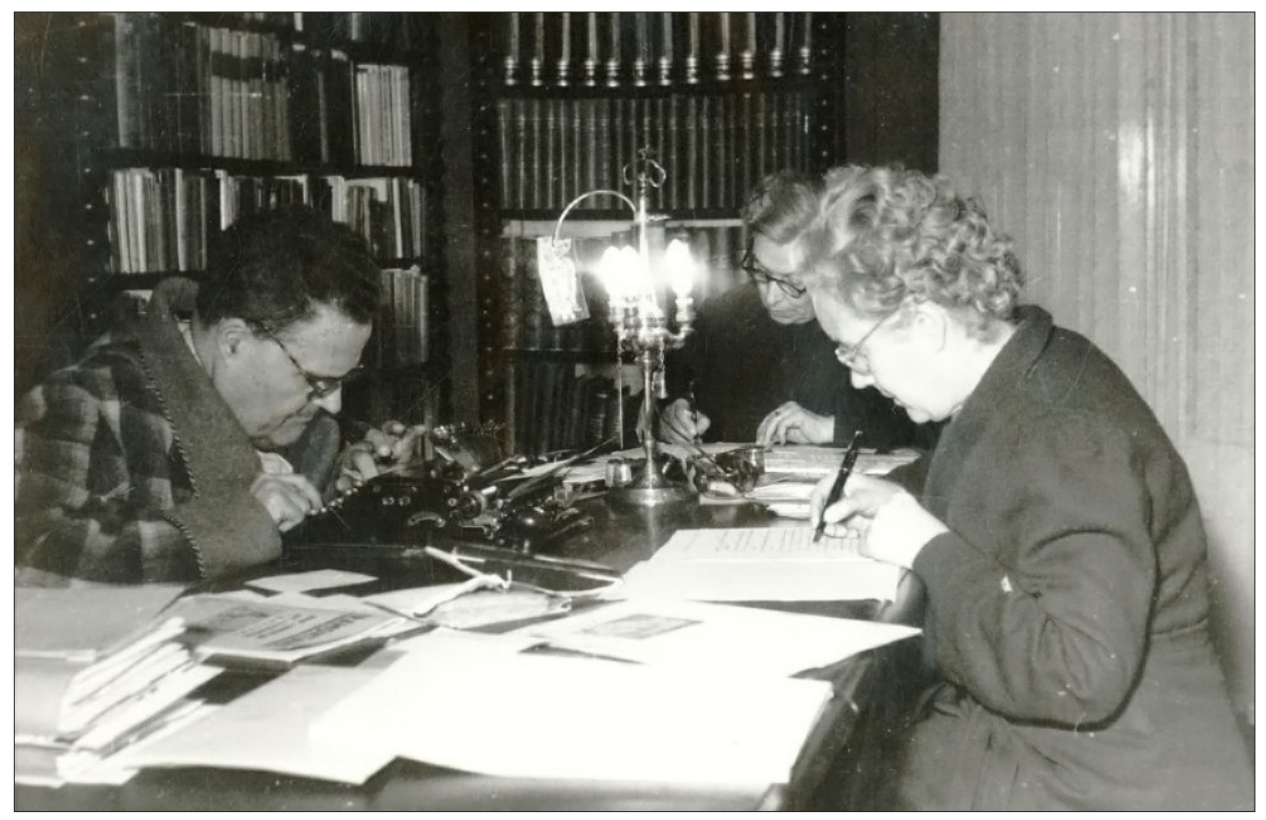

Figure 1. From left to right: Joan Amades, Enriqueta Mallofrè, his wife, and Consol Mallofrè, his sister-in-law, working in his home office in Barcelona in 1956. Fons Joan Amades: Centre de Documentació de Cultura Popular de la Generalitat de Catalunya, Barcelona.

Although Anderson and Amades belonged to the same generation of folklorists, their relationship only began in the later years of their lives, specifically in 1953, after Anderson had sent a letter to Amades. That same year, Anderson retired at the age of 68 and became professor emeritus of folklore at the University of Kiel, where he had worked since $1945 .{ }^{1}$ Meanwhile, Amades had held the position of curator of the prints and imagery section at the Museu d'Indústries i Arts Populars del Poble Espanyol in Barcelona from 1949 (Calvo 1990: 159, note 138$){ }^{2}$

During this period, Amades published Les cent millors rondalles populars (1948-1949) and Folklore de Catalunya: Rondallística (1950). These works were very well received by specialists, in particular those interested in comparative studies because Amades's works provided them with new tales that they could incorporate into their research.

Amades corresponded with the leading folklorists of the day in areas relating to the study of folktales, such as sharing versions, carrying out editorial projects, exchanging information on conferences, publishing articles, etc. Among others, Amades was in regular contact with Aurelio M. Espinosa, Ralf S. Boogs, Arnold Van Gennep, Paul Delarue, Stith Thompson, and Kurt Ranke; however, the 
folklorist with whom he most frequently corresponded was undoubtedly Walter Anderson.

The excellent relationship between Walter Anderson and Joan Amades can be seen in the content of the letters that Anderson wrote to Amades. After the latter's death, Anderson continued to correspond, for a short period, with Amades's widow Enriqueta Mallofrè, and her sister, Consol Mallofrè, who had collaborated on the many works that Amades published during his life (see Figure 1). All of this correspondence has recently been published (Oriol 2014) ${ }^{3}$ and is held in the Amades archive at the Catalan Government's Centre de Documentació de Cultura Popular in Barcelona. In this article, however, I will only study the letters that Anderson sent Amades since these constitute the main body of the letters that have been preserved. Unfortunately, it has proved impossible to locate the correspondence that Amades sent to Anderson, despite various attempts to do so. ${ }^{4}$

The aim of this study is therefore to ascertain the extent of the collaboration that took place between the two folklorists, and to examine the subjects that they discussed in their letters in the context of folklore studies of the time. Although we can only rely on the information provided in Anderson's letters, these are often sufficiently explicit to allow us to deduct part of the content of the letters sent by Amades.

\section{WALTER ANDERSON'S LETTERS TO JOAN AMADES}

Anderson's correspondence to Amades was written sporadically between 18 January 1953 and 5 December 1958. The documents consist of 26 letters and 5 postcards (although for practical purposes all of the documents are referred to as letters throughout this study) and their distribution by year is as follows: 7 were written in 1953; 5 in 1954; 1 in 1956; 10 in 1957; and 8 in 1958. More than half of the letters were therefore written in 1957 and 1958; that is, in the last two years of Joan Amades's life.

Anderson wrote all the letters in French. ${ }^{5}$ In the early letters, as is natural in any initial contact, he uses a very formal tone, while in the later letters the tone is more informal. For example, in the earlier letters he uses the closing formula En vous priant d'excuser mon audace (I beg your pardon for my boldness), whereas in the later ones he uses more informal expressions such as Mille saluts (A thousand greetings).

Another feature of the letters is their pedagogical tone, which is apparent not only in their content, but also in their form. Anderson writes his letters simply and clearly. He often organises the contents into numbered sections 


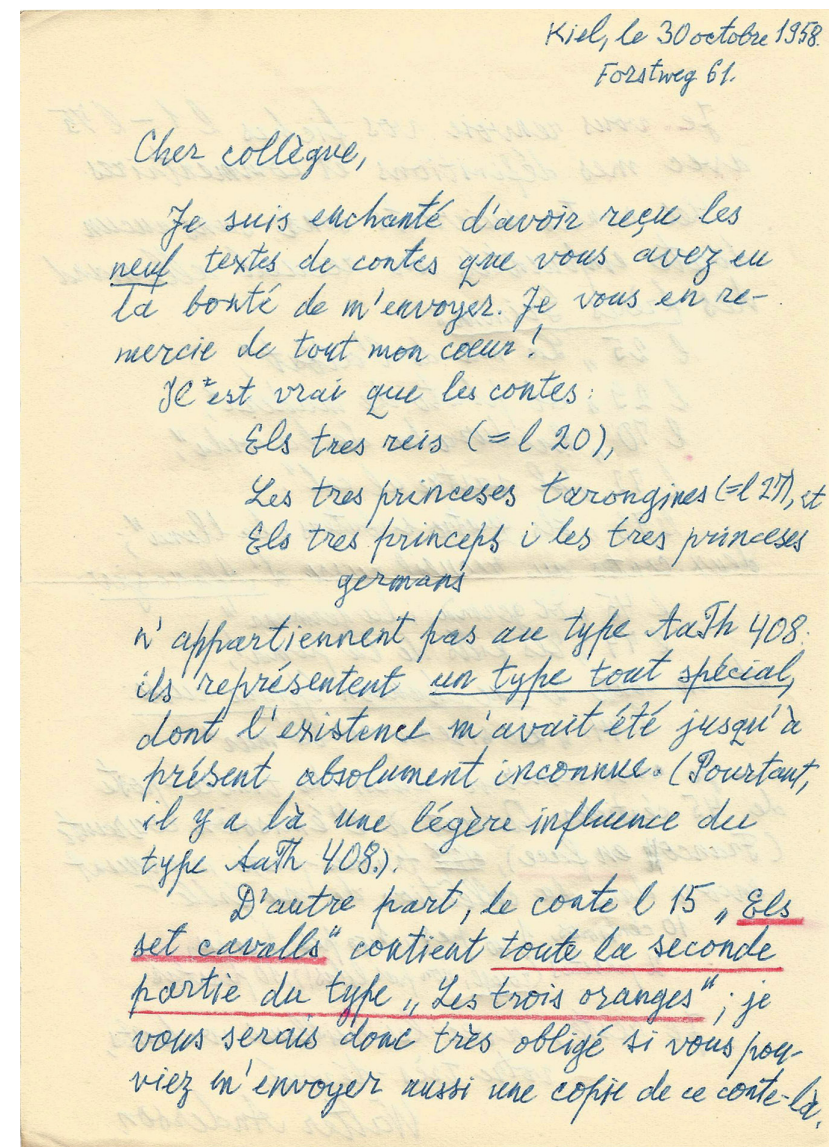

Figure 2. First page of a letter from Walter Anderson to Joan Amades, dated 30 October 1958. Fons Amades: Centre de Documentació de Cultura Popular de la Generalitat de Catalunya, Barcelona.

so that the issues addressed are well-structured. Furthermore, on many occasions he underlines words or phrases that he considers to be important in much the same way as a teacher would (see Figure 2). Indeed, in his letters Anderson undoubtedly acts as Amades's teacher and discusses theoretical and methodological aspects of the study of folklore, international folklorist associations, publications of interest, catalogues of folktales, cataloguing criteria, etc.

Meanwhile, Amades provided Anderson with texts and summaries of Catalan folktales for his comparative research and sent him information about tales published by Catalan folklorists (e.g. Valeri Serra i Boldú and Andreu Ferrer i Ginard) which Anderson was unaware of. The two folklorists also sent each 


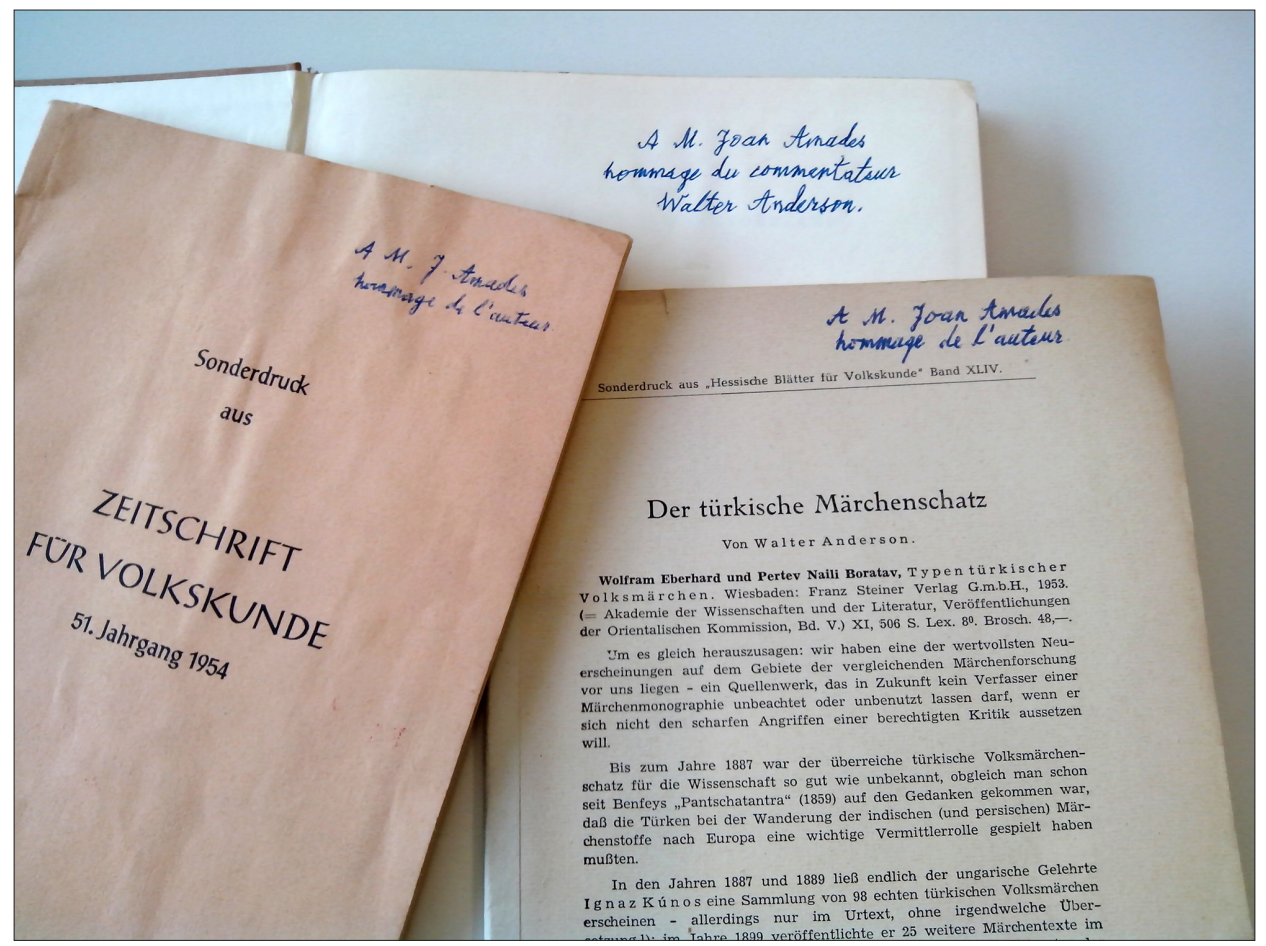

Figure 3. Publications with dedications by Walter Anderson. Fons Amades. Centre de Documentació de Cultura Popular de la Generalitat de Catalunya, Barcelona.

other books and articles that they had difficulty obtaining in their respective countries (see Figure 3).

\section{STUDY OF THE LETTERS}

Although Anderson's letters primarily deal with subjects relating to the study of folklore, he also occasionally provides biographical information about both folklorists. Consequently, the correspondence between the two men allows us to confirm information that we already know and to gather new information about their respective lives and work. Moreover, Walter Anderson's letters give us information provided by the author in the first person, thus making them important historical documents.

The nature and importance of the biographical information contained in the letters is illustrated by the following five points. 


\section{(1) Walter Anderson was a great polyglot}

Walter Anderson had an extraordinary ability to learn languages, which enabled him to successfully undertake so many comparative historic-geographic studies of folktales over the course of his life. ${ }^{6}$

In his first letter to Amades, dated 18 January 1953, Anderson, who was at that time working on a monograph on the tale of The Three Oranges, mentions the need to use versions of the folktale in various languages. In a later letter, dated 26 February 1953, Anderson says that knowledge of foreign languages is the greatest difficulty for those wishing to write a monograph on a folktale; he adds that it is necessary to at least understand all the Romance, Germanic, and Slavic languages (not only the literary languages but also the various dialects), or to have translations of texts written in these languages, which is very expensive. He then refers to his specific circumstances and says that he is relatively fortunate as he is able to understand texts in over forty languages (including Finnish, Estonian, Hungarian, Hebrew, Arabic, Persian, and Turkish).

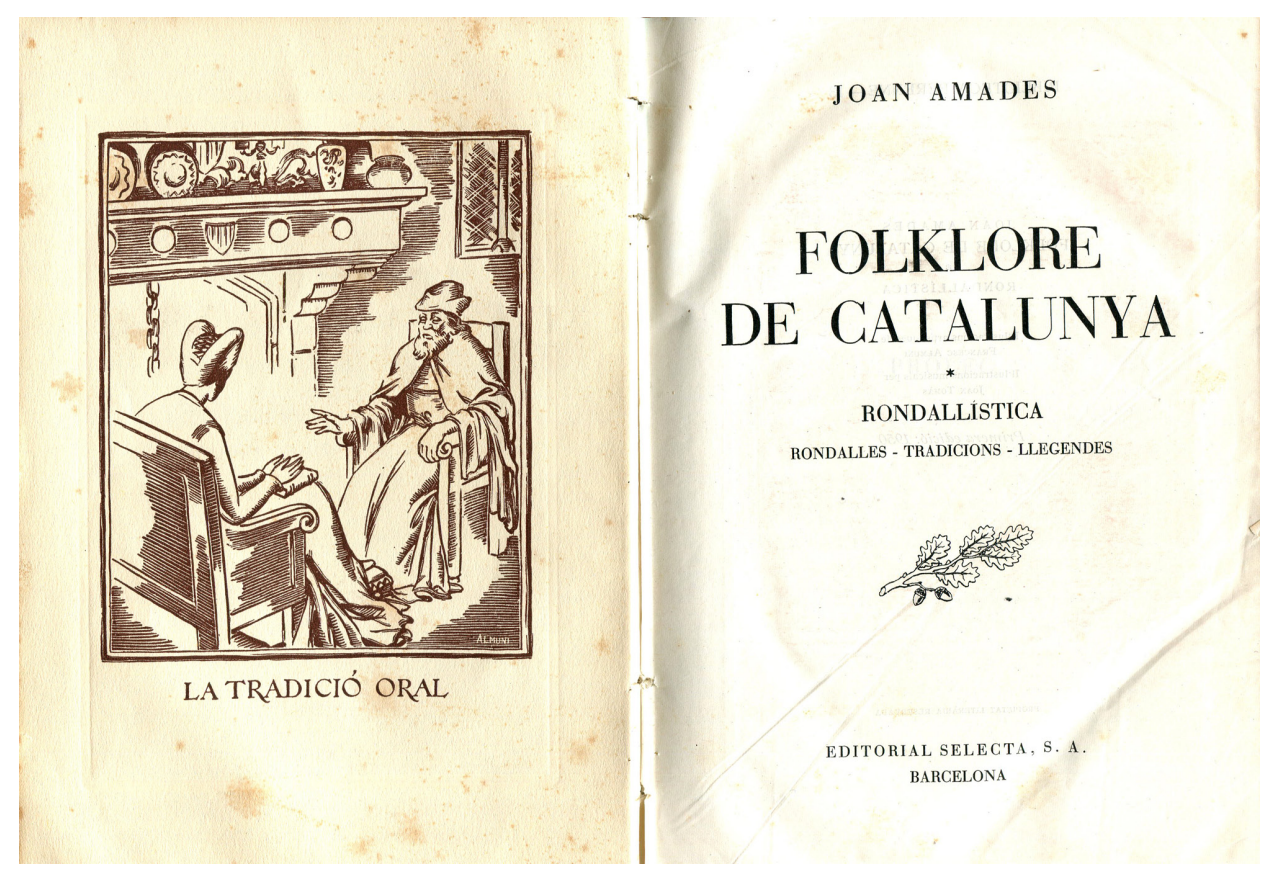

Figure 4. Frontispiece and cover of the first edition of the book Folklore de Catalunya: Rondallística (Amades 1950). 
Anderson understood Catalan, as he said in his first letter, which like all the others was written in French: "I understand Catalan and Spanish, but I do not know these two languages well enough to use them in my letters". ${ }^{7}$ Consequently, Anderson was able to read the folktales that appeared in the book Folklore de Catalunya: Rondallistica (Amades 1950), among others (see Figure 4). He was also able to understand the Majorcan dialect of Catalan, which in turn meant that he could read the Majorcan folktales collected in the books by Antoni M. Alcover, use them in his studies of comparative folktales, ${ }^{8}$ and catalogue them. ${ }^{9}$

Anderson's interest in languages, and in the Catalan language in particular, is highlighted in a letter written on 12 September 1957. In this letter, Anderson asks Amades about the meaning of the word clatell, which appears in the folktale L'amor de les tres taronges ${ }^{10}$ (The Love for Three Oranges) (ATU 408) and the folktale Maria Roseta ${ }^{11}$ (C-011). ${ }^{12}$ The word clatell $^{13}$ refers to the nape of the neck, and is much more widely used in Catalan than its synonym nuca. This is interesting because clatell belongs to a lexical family different from the corresponding terms used in other Romance languages. For example, in Spanish clatell is nuca, cogote, or cerviz, in French it is nuque, in Italian it is nuca, coppa, or collo, and in Portuguese it is nuca, pescoço, or cerviz. It is therefore difficult to guess the meaning of clatell by comparing the word with other Romance languages. This is undoubtedly why Anderson had difficulties understanding it and why, after mentioning that he had no access to a dictionary at the time, he asked Amades for the meaning of the word.

\section{(2) Walter Anderson lost his entire library as a result of the war}

One of Anderson's letters, dated 21 September 1957, discusses the loss of his library during the siege of Königsberg, which took place at the end of the Second World War, in 1945. This siege led to the destruction of almost the entire city and its annexation by Russia, under the new name of Kaliningrad. Anderson's loss of his library has been mentioned by other authors including Levin (1963: 294) and Seljamaa (2005: 159), and indeed Anderson himself briefly refers to it in one of his letters to Amades:

As regards the three works you would like to see, I cannot send you my own copies as they have been destroyed (as were all my books and manuscripts) during the siege of Königsberg (1945); however, you will soon receive three books from the commissioner of the Finnish Academy of Sciences, and I would ask you to accept them as proof of my gratitude. ${ }^{14}$ 


\section{(3) Joan Amades was a member of Folklore Fellows}

We know about Amades's membership of Folklore Fellows thanks to the information contained in Anderson's letters. During those years, the association operated in a highly unusual manner, as we will see below.

Anderson had told Amades about the organisation's existence in his letter dated 26 February 1953, and Amades must have asked him for further information about it because in his letter dated 4 April 1953, Anderson refers to it in the following terms:

The organisation Folklore Fellows in which you are interested is a very strange organisation; it has no president, no committees, no branches, no budget, no meetings, no minutes, and no reviews. ${ }^{15}$

He then explained that almost all of these items had been planned when the federation was founded (in 1907), but had not been implemented because they were considered superfluous. Anderson made his own personal assessment by saying:

The Federation is somewhat similar to the Republic of Letters imagined by Erasmus of Rotterdam: one becomes a member either by declaring (or by showing) that one is willing to help other folklorists with their studies - and now you are a member, as I am. If any folklorist is in need of any Catalan folklore material, I shall give them your address - in the same way as I received yours from Mr. Paul Delarue. And if you need materials, bibliographical information, etc., I and all the other folklorists will be happy to assist you. That is all; there are no formalities or membership lists; I myself am a member of the editorial board of the FF Communications (the Federation's only committee), i.e. the series published on behalf of the Folklore Fellows and funded by the Finnish Academy of Sciences. Since 1926, my name, together with another five names, has been on the covers of all volumes in this series (there are now 60, consisting of 144 issues), and yet neither I nor my other five colleagues (including Professor Martti Haavio, who is the head of the committee) possess any documents to show that we are editors (or even members of the Federation). ${ }^{16}$

The statutes of Folklore Fellows (Statuten des Bundes "FF") are recorded in a short text of ten paragraphs, which was published in Volume 4 of the collection Folklore Fellows' Communications (Krohn 1910). 


\section{(4) Walter Anderson and Joan Amades were both keen philatelists}

Anderson's interest in numismatics is well known (Ranke 1962, 1977: 494), but his letters also reveal to us that he was a keen philatelist and that he must have passed this interest in stamp collecting on to his daughter because at the end of the letter dated 30 October 1958, Anderson tells Amades which stamps his daughter needs for her collection. And in the last letter Anderson wrote to Amades, dated 5 December 1958, he thanked him for the two stamps and the folktales he had been sent.

After the death of Amades, Anderson continued a brief correspondence with Amades's wife and sister-in-law, as mentioned above, and the content of one of these letters shows that they also sent him stamps. Thus, in the letter dated 21 December 1960, Anderson includes a postscript stating: "Merci beaucoup aussi pour les 49 timbres-poste!" (Thank you also for the 49 stamps!).

We know that Amades and his sister-in-law were also avid stamp-collectors ${ }^{17}$ because of the stamp albums kept in the Amades archive in Barcelona.

\section{(5) Walter Anderson and Joan Amades met in person}

Anderson's letters show us that the two folklorists met in person. The letter dated 1 September 1954 mentions the first meeting between the two folklorists at a congress in Naples. In this letter Anderson says that he has seen Amades's name on the list of those attending the congress in Naples and is looking forward to meeting him in person because, notwithstanding any unforeseen difficulty, he also plans to attend. In the biography of Amades (Calvo 1990: 236), the only congress that Amades is known to have attended in Naples in 1954 was the Congresso Internazionale di Etnografia e Folklore del Mare, which took place on October 3-10. At the congress, Amades presented the communication under the heading Rito di una construzione di una barca. ${ }^{18}$ However, I have been unable to confirm that this is the congress Anderson refers to or indeed if the two folklorists actually met on this occasion.

In another letter dated 29 May 1958, Anderson refers to two more meetings that took place in 1955 and 1958 respectively. The letter does not provide enough information to ascertain where the 1955 meeting took place; however, it is more explicit regarding the 1958 meeting. In this letter, Anderson writes:

I hope to visit you in Barcelona at the end of June. I intend to participate in a congress to be held in Porto from 18 to 23 June (Colóquio de estudos etnográficos Dr. José Leite de Vasconcelos). I will travel (if the political situation permits) via Irun, but I will return via Barcelona, where I plan to stay for one or two days. ${ }^{19}$ 
Anderson's letter crossed paths with those that Amades wrote to him on 30 May and 1 June 1958. In these letters, Amades must have told Anderson that he also intended to attend the conference in Porto because in Anderson's next letter, dated 6 June 1958, he acknowledges receipt of the two letters from Amades and concludes with “Au revoir à Porto!" (See you in Porto!). We also have a photograph in the Amades archive in Barcelona showing that the two folklorists met at this conference (see Figure 5).

In addition to these essentially biographical data, Anderson's letters provide information about his professional work as a folklorist and feature comments and explanations on a whole range of subjects, including a monograph titled The Three Oranges (ATU 408), international folklore associations and archives, an article titled A Folklore Experiment, a review of the book Folklore de Catalunya: Rondallística (Amades 1950), the concept of the folktale, a project for cataloguing Catalan folktales, and a catalogue of Catalan etiological legends.

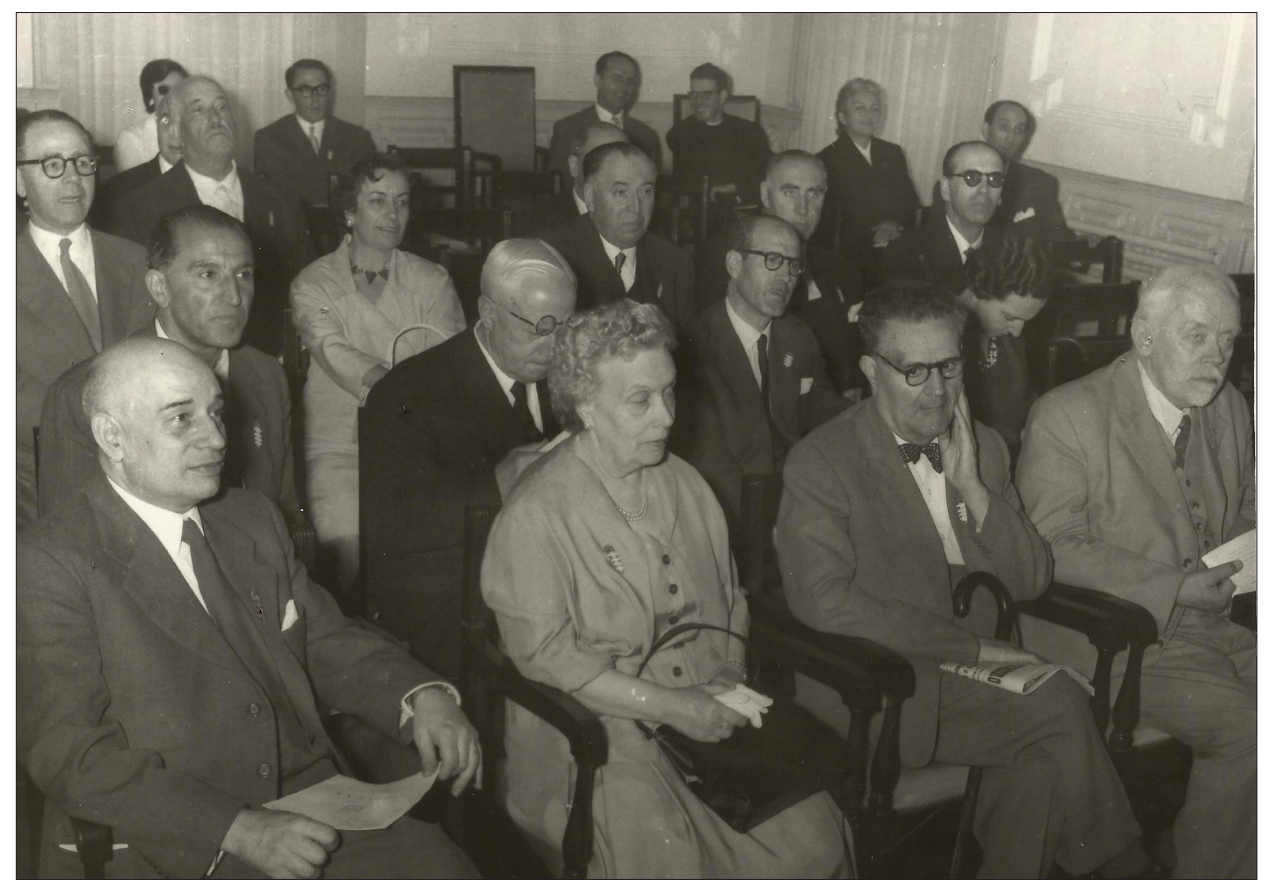

Figure 5. First row from right to left: Walter Anderson and Joan Amades with his wife, Enriqueta Mallofrè, at the Colóquio de estudos etnográficos "Dr. José Leite de Vasconcelos”, Porto, 1958. Fons Amades: Centre de Documentació de Cultura Popular de la Generalitat de Catalunya, Barcelona. 


\section{THE THREE ORANGES MONOGRAPH (ATU 408)}

Walter Anderson, who had been working on the monograph of the tale of The Three Oranges for some years ${ }^{20}$ heard of the existence of two Catalan versions in the volume Folklore de Catalunya: Rondallística (Amades 1950), as a result of his collaboration with the French folklorist Paul Delarue. Specifically, Delarue sent Anderson the texts of folktales No. 62, Les tres taronges de la vida (The Three Oranges of Life), and No. 93, L'amor de les tres taronges (The Love for Three Oranges). This led to Anderson's first letter to Amades on 18 January 1953, in which he asked him to clarify some questions regarding these versions and whether he had other manuscript versions of the folktale. Anderson was studying the tale of The Three Oranges from the historic-geographic perspective, hence his remark to Amades that he was attempting to compile all the versions of the folktale in existence, and that he had already compiled more than two hundred from Europe, America, Africa, and Asia (where the story is well known even in China and Korea).

The historic-geographic method aims to determine where and when a folktale originated and how it has spread; consequently, researchers who use it need to collect as many versions from as many countries as possible.

Amades must have replied that he had no manuscript versions of the tale and seems to have sent him a list of published versions instead, because Anderson, in his letter dated 5 February 1953, tells him that he knows of all of them except the one by Valeri Serra i Boldú, Rondalles populars (Serra i Boldú 1930: 45), and says he would be very grateful if he could copy this text for him and send it.

Rather than the complete text, Amades sent him a summary of the folktale, because on 15 February 1953 Anderson thanks him for his highly detailed summary and then asks a series of questions relating to the version, including:

(1) Are the giant's eyes open while he is asleep (and closed when he is awake) or not? (2) Does the witch stick the enchanted needle in the girl's ear or elsewhere on her head? (3) Does the girl turn into a dove or another bird? (4) Does the witch promise the prince that she will become beautiful again or not? (5) Does the bird come to the prince's garden to talk to the gardener three times, or not? (6) If so, what do the bird and the gardener say ${ }^{21}$

Then Anderson, in a very cordial tone, says that he regrets having to ask so many questions, but that it is precisely these minor details that enable him to reconstruct the history of the development and migration of the folktale.

In the following letter, dated 26 February 1953, Anderson thanks Amades very warmly for replying to his questions on the Serra i Boldú version, and for 
sending him three new Catalan versions of the tale of The Three Oranges. Anderson believes that the Catalan tradition of the folktale is well represented as he has thirteen versions of it. In the same letter, he says that he cannot begin writing his monograph before the end of the year, as he still needs some important texts published in books that are relatively inaccessible. For this reason, he will still be able to use any materials that he finds or that are sent to him.

Amades was willing to help him, and continued to send him versions of the folktale. We know this, for example, from the letter dated 16 October 1954, in which Anderson thanks him for sending three unpublished versions of The Three Oranges and says that he will use them in the analysis of the folktale to reconstruct its original form and the subsequent evolution, and he will mention the Arxiu Històric Municipal de Barcelona (see Figure 6). ${ }^{22}$

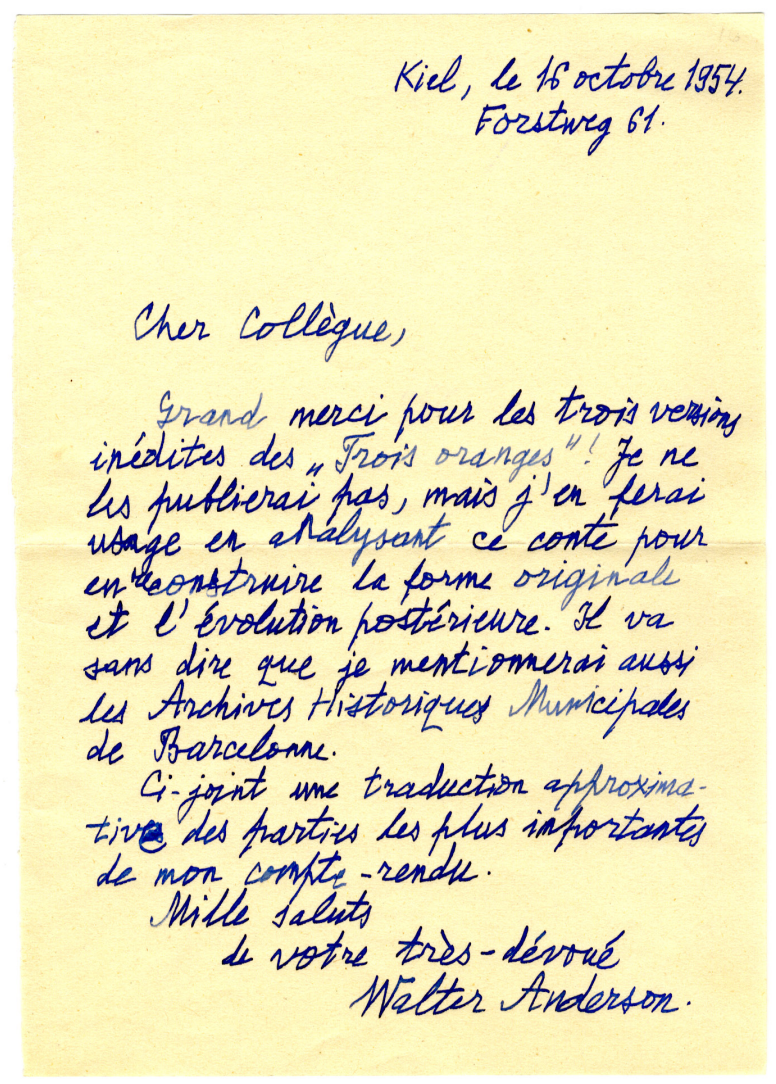

Figure 6. Letter from Walter Anderson to Joan Amades, dated 16 October 1954. Fons Amades: Centre de Documentació de Cultura Popular de la Generalitat de Catalunya, Barcelona. 
Anderson never published the monograph about the tale of The Three Oranges. The text is preserved in the archives of the Enzyklopädie des Märchens and consists of 746 handwritten sheets of A5 paper. ${ }^{23}$ Anderson used a total of 22 Catalan versions (as can be seen in the text of the manuscript) with the RC code followed by the corresponding number. The letter ' $R$ ' indicates that the version is Romance, and the letter ' $\mathrm{C}$ ' shows that it is Catalan. However, the manuscript is incomplete and lacks the part containing the bibliographical references; we are therefore unable to ascertain which Catalan versions Anderson used.

In the second revision of the Aarne-Thompson catalogue (1961), Walter Anderson was responsible for the description of type 408, The Three Oranges (as explicitly stated), and the monograph he was preparing was cited as a paper intended for publication in the near future, although, in the event, this never happened.

\section{INTERNATIONAL ASSOCIATIONS AND FOLKLORE ARCHIVES}

In his letter dated 26 February 1953, Anderson discusses Nordic folklorists' organisations, which indicates that in his previous letter Amades must have shown some interest in them. Anderson refers to them in the following terms:

The Nordic folklorists' organisations you referred to are not special societies, but are instead archives in which a nation's entire folklore material (printed or handwritten) is compiled and preserved. These archives can be found in Copenhagen, Oslo, in various parts of Sweden, Helsinki, Tartu, and Riga. In Germany, there are the archives of folk songs and tales in Fribourg, and the folktales archives in Marburg. Even the great Folklore Fellows is not really a truly international society, but instead an ideal league of all the world's folklorists who have pledged to help each other in their studies. ${ }^{24}$

Anderson then discusses the books in the FF Communications collection, as Amades must have asked him if it was possible to publish them in Catalan. In response, Anderson explains that they are an international series published on behalf of Folklore Fellows by the Finnish Academy of Sciences but that at the time of writing all of its publications had always been in German, English, or French. He then goes on to point out that neither of Finland's two (very different) official languages, Finnish and Swedish, had ever been included in this series. He concludes by suggesting that perhaps something in Italian could be published, whereas Spanish would be much more doubtful, and a work in 
Catalan would have very few readers. He concludes by saying: "Knowledge of your beautiful language is unfortunately very limited in the world". ${ }^{25}$

\section{THE 'FOLKLORE EXPERIMENT' ARTICLE}

Anderson sent Amades a copy of his work titled Ein Volkskundlische Experiment (Anderson 1951) ${ }^{26}$ and, in his letter dated 26 February 1953, he briefly explains its contents as follows:

Over thirty years ago, I established a theory that every man who tells a folktale has heard it not only once in his life, but instead many times and from many different people; otherwise, the folktale would constantly be changed and distorted until it would soon be unrecognisable. ${ }^{27}$

Anderson's comment refers to one of his major contributions to the study of folklore of the time: the Law of Self-Correction. This law was formulated by Anderson in the monograph type ATU 923, Kaiser und Abt (The Emperor and the Abbott) (Anderson 1923), and he says in his letter: "This thesis was opposed by many folklorists who did not want to believe it". ${ }^{28}$

He then explains the experiment he has carried out, which is at the heart of the work he sent to Amades:

In order to resolve the issue, I read a (little-known) legend to three students at our university, and asked them to write it down the next day just as they remembered it at that time, and then asked each one to read it to another student, who would do the same the next day; and this procedure was repeated twelve times. As a result, I obtained three sets of twelve texts each, and the final texts in these series (A12, B12, C12) were all totally distorted and with major discrepancies between them, which was exactly what I had expected. Twenty years ago, I carried out some similar experiments in Estonia (without publishing the results); the results were absolutely identical. ${ }^{29}$

The theses that Anderson put forward in his work became the focus of debate not only among contemporary folklorists but also among future generations. This can be seen, for example, in the extensive bibliography that accompanies the article Experimentelle Erzählforschung, published in the Enzyklopädie des Märchens (Oring 1984). 


\section{THE REVIEW OF THE BOOK \\ FOLKLORE DE CATALUNYA: RONDALLÍSTICA}

In his letter dated 26 February 1953, Anderson tells Amades that if the latter sent him some of his work, Anderson would be happy to review it in a Swiss or German folklore journal. A subsequent letter, dated 1 October 1953, tells us that Amades sent him the two volumes of the anthology, Les cent millors rondalles populars (Amades 1948-1949), ${ }^{30}$ because Anderson thanks him for doing so and says that he has taken many notes although he admits that he has still not had time to write the review he promised as he is in the middle of some other urgent work.

However, in the following letter, dated 11 February 1954, Anderson says that instead of publishing a review of the anthology, he has decided to write one about a large collection, amounting to 1,735 pages, which has been brought to him from Spain. The work Anderson is referring to is undoubtedly Folklore de Catalunya: Rondallística (Amades 1950). In the same letter, Anderson adds that he is studying Amades's unique collection, that his review will be about a dozen pages long, and that this review will mention Amades's anthology (in two volumes).

This decision is not surprising given that Anderson greatly admired the size and breadth of this book and found it very useful in his comparative studies (see Figures 7 and 8). For this reason, in the letters dated 18 January 1953 and 11 February 1954, he describes the work as a "monumental collection" 31 and a "unique collection" respectively. ${ }^{32}$ In the later letter ${ }^{33}$ he also says:

Reading your great book has given me many surprises: when reading folktale no. 231, "The man who turned into a donkey", my eyes widened: this folktale has been very well known in Germany since the Thirty Years' War (the versions include two from the seventeenth century), a folktale that is probably derived from the novel by Apuleius and which I was very familiar with as I studied it about forty years ago! But I did not have the slightest idea that the tale was known to other peoples - and especially to the Catalans! ${ }^{34}$

And in yet another letter ${ }^{35}$, Anderson writes, "It is impressive to read that you have compiled so many folktales and songs: 15,000 is a huge number". ${ }^{36}$

Anderson reviewed Amades's book (Anderson 1954) in which he catalogued the folktales according to the Aarne-Thompson system (1928). In a later letter, dated 16 October 1954, Anderson sent Amades a rough translation (in French) of the most important parts of the review. Anderson basically emphasises two aspects: (1) the length of the book, which contains a total of 2,215 numbers cor- 


\section{ches Collègue, \\ Kine, 623 fentin 1954 \\ Te erous remersic le flus} vivement she nouveau texte

que vous avez en la bonte. de mienvoyer, at qki sans votre secours the serait resté inaccessifle.

$\gamma_{0}$ suis toujours à étudier votre inéfuisable recucil: plus $j^{\prime \prime} y$ lis - phes je

\section{Votre très-dévocé} Watter troderstos.

\section{PROT. DR. WALTER \\ (246) ANDERSON \\ FORSTWEG 61

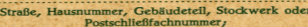 \\ bet Untermiletern auch Name des Vermileters}

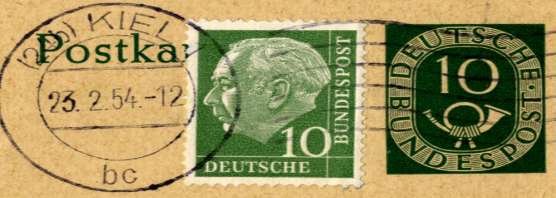

$S_{R}$ J. AMADES

PROVENZA, 209

BARCELONA

(ESPAC,NE)

Figures 7-8. Postcard from Walter Anderson to Joan Amades, dated 23 February 1954. Fons Amades: Centre de Documentació de Cultura Popular de la Generalitat de Catalunya, Barcelona. 
responding to folktales, stories, and legends; and (2) its importance to specialists due to its richness and variety.

Because of these characteristics, Anderson felt it was necessary to catalogue the folktales in Amades's book, giving the following explanation:

If a specialist is looking for versions of a given folktale, how will he fish for them in the ocean of the Catalan book? Versions of the same folktale are often scattered in different places, such as wonderful true folktales (due to an accidental location) in the chapter on legends of castles. Will the specialist have to follow my example, sacrificing many weeks studying the Catalan book? That is not something everyone can do! In order to at least partially remedy this problem, the following table shows the numbers under which the reader will find the tale-types stipulated by Aarne and Thompson. ${ }^{37}$

The catalogue included in Anderson's review (1954) does not exactly match the one included in the second revision of the Aarne-Thompson catalogue (1961), as has been highlighted by Oriol (1990). The causes for the differences between these classifications are unclear. On the one hand, Thompson would undoubtedly have used the catalogue published by Anderson. However, on the other hand, Anderson himself subsequently modified his own cataloguing system. Evidence of some of the amendments made by Anderson can be found in his letter to Amades, dated 29 May 1958, in which he includes a short list of types with the corresponding corrections (see Figures 9 and 10).

However, Anderson would not have sent these amendments to Thompson, who at that time was working on the second revision of the international catalogue (Aarne \& Thompson 1961). This is made clear by Anderson in a letter dated 30 January 1958, in which he says that he has not sent the amendments to Thompson and that Amades must contact him himself. As can be seen in the same letter, Anderson intended to revise the way in which Folklore de Catalunya: Rondallistica (Amades 1950) was catalogued, and to send Amades a copy of this revision so that he could use it in his own catalogue. Anderson soon put his intention into effect when in his letter dated 29 May 1958 he sent Amades a 45-page review of the folktales contained in Amades's book.

\section{THE CONCEPT OF THE FOLKTALE}

Amades must have soon told Anderson that he was having difficulties in defining the term 'folktale' and that this was a problem for him because he was thinking of producing a catalogue of Catalan folktales and he needed to be able to 


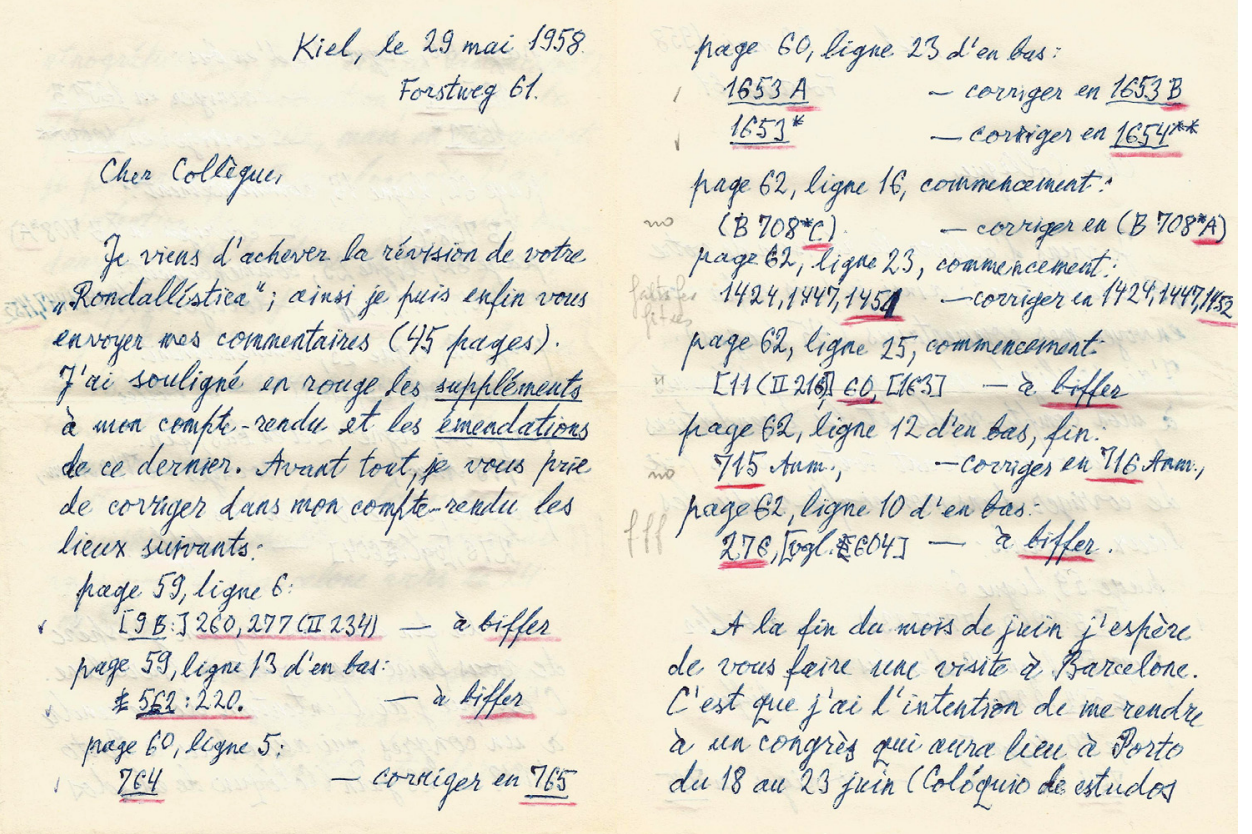

Figures 9-10. Initial pages of the letter from Walter Anderson to Joan Amades, dated 29 May 1958. Fons Amades: Centre de Documentació de Cultura Popular de la Generalitat de Catalunya, Barcelona.

decide which ones he should include (Oriol 1999: 370). This would explain the following excerpt from Anderson to Amades, dated 1 October 1953:

As regards the definition of a folktale, I must confess that I am not particularly concerned with definitions and classifications - certainly less than you are, as a compatriot of Ramon Llull. There are so many things in the universe that defy rigorous definition - so many transitional or hybrid forms that cannot be classified. I would call a 'folktale' a narrative of something that happened once, but not of something that often happens in the present. Many savage peoples believe that the sun or the moon is devoured by a monster during each eclipse, and then emerges from its belly: that is not a folktale, it is a belief. The Russians say that the earth rests on three giant whales, whose tremors cause earthquakes: that is also a belief, not a folktale. However, there are also peoples who believe that in ancient times, there were 10 suns in the sky that mercilessly scorched the land, until a hero killed nine of them with his arrows: that is a genuine folktale - an etiological folktale. 
There are folktales that explain the origin of a proverb or a riddle, or a teasing nickname: these are always folktales; but fingerplays are not: they are instead small representations rather than folktales. I would also not classify mathematical problems [---] or the texts that you call 'embarbussaments' [tongue-twisters] as folktales. ${ }^{38}$

It can be seen here that Anderson approaches the issue of genres of folktales with a certain degree of pragmatism. This is hardly surprising from someone who had read, studied, and catalogued thousands of texts over the years and was therefore aware of their diversity. So he decided to offer Amades an explanation that aimed, above all, to be practical and avoided sweeping definitions.

In the same letter, Anderson explains to Amades the differences between the books Motif-Index of Folk Literature (Thompson 1932-1936) and Types of the Folktale (Aarne \& Thompson 1928), which Amades must have asked about with regard to cataloguing Catalan folktales. This may have been related to the fact that Amades had been commissioned by UNESCO to produce a bibliography and classification of Catalan folktales. Although it has been impossible to ascertain precisely how this commission came about, Walter Anderson and Paul Delarue both seem to have played a part in it, particularly because the latter was secretary of a UNESCO committee devoted to the study of folktales (Calvo 1990: 172, note 187).

\section{THE CATALAN FOLKTALE CATALOGUING PROJECT}

From 1954 onwards, the collaboration between Anderson and Amades focused mainly on the task of cataloguing Catalan folktales. In a letter dated 1 September 1954, Anderson is keen to help Amades obtain the Aarne-Thompson catalogue (1928). He says: "I will do everything possible to send it to you within a few weeks". ${ }^{39}$

In an undated letter from 1954, Anderson gives clear instructions about which tales need to be catalogued. He says:

You were right: preparing a national catalogue of folktales is an extremely useful task, but also a very extensive and difficult one. If possible, all the folktales must be recorded, including those which have been published in almanacs, magazines, newspapers, etc., and those that have not been published, as well as those that have been printed in books for children, provided that they are not artificial re-workings of texts already recorded in your catalogue. 
However, you do not have to take into account local legends about fairies, giants, mermaids, etc., those about fabulous countries and ships, or legends about the lives of saints or religious miracles. Those things are very interesting, but they require a special catalogue.

As for anecdotes and jokes, as many as possible should be recordedand at least all those named in the Aarne-Thompson catalogue. However, purely local anecdotes (e.g. blason populaires, etc.) may be omitted, as well as interpretations of birdsong and mathematical problems..$^{40}$

Anderson goes on to explain the criteria he used to catalogue the folktales in the book Folklore de Catalunya: Rondallística (Amades 1950). He says:

Reading your great collection, I have not recorded all your folktales, but instead only those listed in Aarne and Thompson's catalogue, and those that are missing from it but which are nonetheless very well-known and important. I have covered all of this in my review. ${ }^{41}$

It is clear from this that Anderson was undoubtedly an expert cataloguer whereas Amades was only just beginning to familiarise himself with the process. Therefore, Amades must have been incredibly grateful for the following offer that Anderson made in the same letter: "If you have any concerns about any folktale, send me a brief summary of it or the appropriate number in your Rondallistica and I will give you my opinion". ${ }^{42}$

Between 1954 and 1957, Amades was working on editing the book titled Contes Catalans (Catalan Tales), which Delarue had commissioned for the collection Contes des Cinq Continents (Tales from Five Continents) (Amades 1957) (see Figure 11). The annotations on the informants were provided by Amades, while Anderson was responsible for cataloguing the folktales.

Figure 11. Bookplate from the back cover of the book Contes Catalans (Amades 1957). Fons Amades: Centre de Documentació de Cultura Popular de la Generalitat de Catalunya, Barcelona.

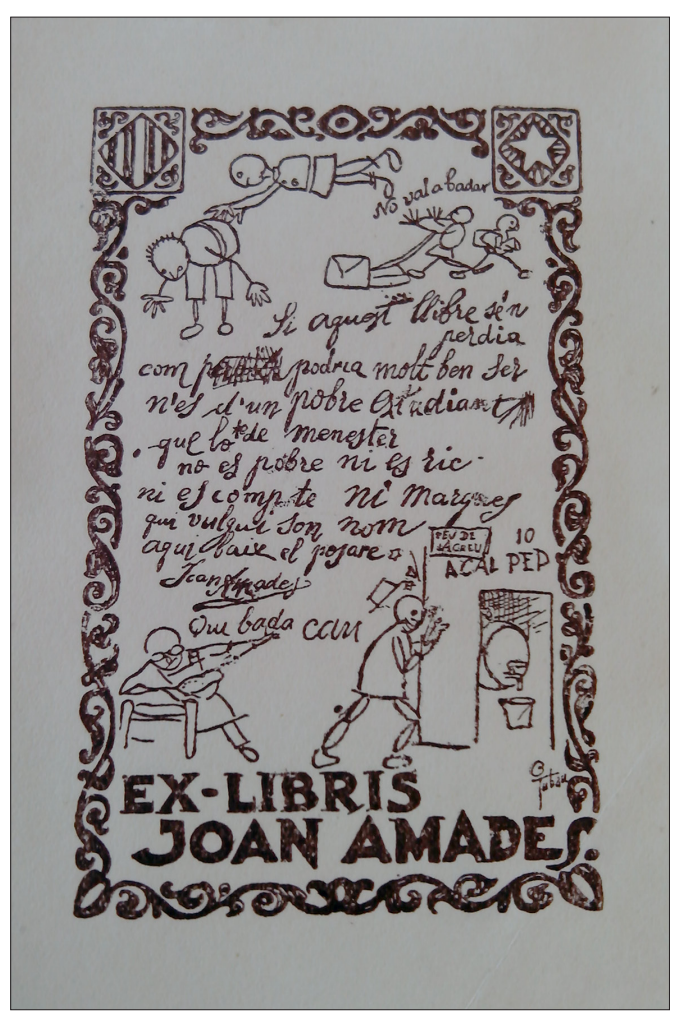


The correspondence between Anderson and Amades intensified in 1957 with the most frequent subject continuing to be the cataloguing of folktales. In his letter dated 10 April 1957, Anderson sent a postcard to Amades, in which he says that he would be delighted to classify the folktales from all the collections sent to him as his Rondallistica is the only Catalan collection in the libraries of his city. He goes on to insist: "In general, I will do everything possible to help you in your undertaking". ${ }^{43}$

On 2 May 1957, Anderson informs Amades that he has received the fourteen volumes by Alcover, although he also says that he would need a few weeks to read and classify these long folktales. He then states that he has only received volumes I-VII and IX-XV, that perhaps stocks of volume VIII have run out, but that he will be able to order it from the Lateinamerikanische Bibliothek in Berlin (which has volumes I-XIV) ${ }^{44}$ (see Figure 12).

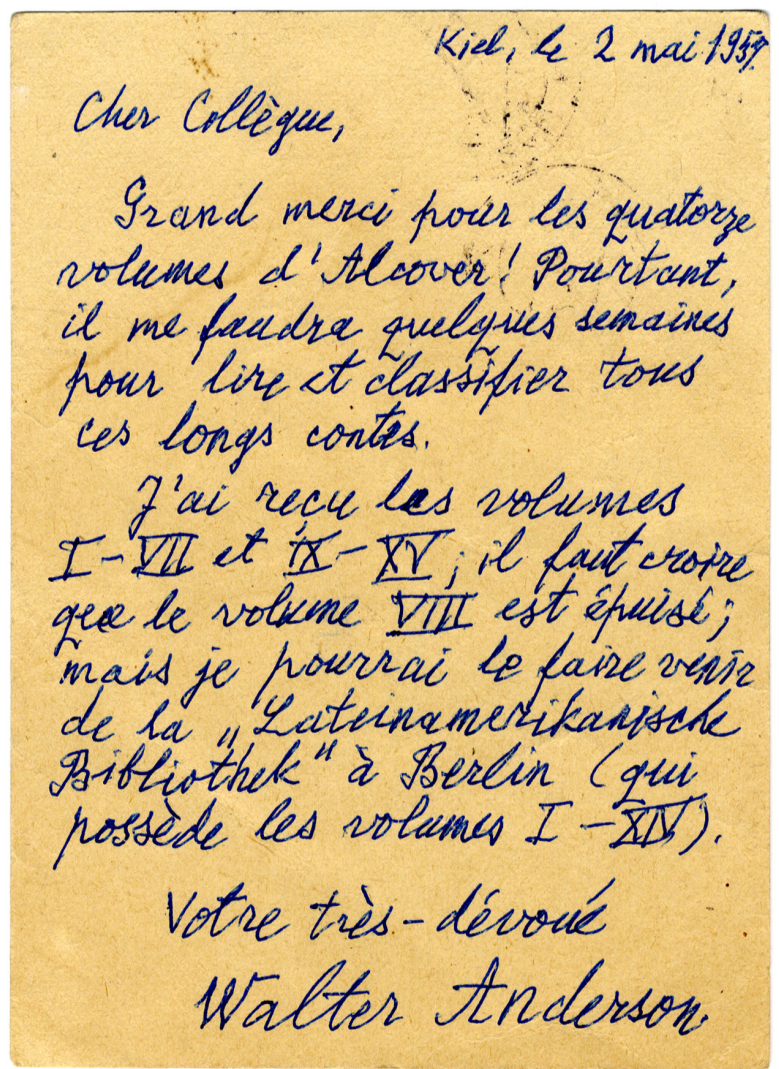

Figure 12. Postcard from Walter Anderson to Joan Amades, dated 2 May 1957. Fons Amades: Centre de Documentació de Cultura Popular de la Generalitat de Catalunya, Barcelona. 
Throughout 1957, Amades must have immersed himself in cataloguing Catalan folktales, collecting books of folktales and selecting material to send to Anderson $^{45}$ because in the letter dated 25 August 1957, Anderson once again clearly acts as Amades's mentor when he says:

You ask me to clearly explain to you which folktales have been excluded from the Aarne-Thompson system. Unfortunately, this is almost impossible; we would need a new Ramon Llull to give you all the definitions, distinctions, and classifications that you would like. We can say that in general, religious, biblical, etiological, historical, and local legends are excluded from this system; separate catalogues are produced for all the folktales in these genres. ${ }^{46}$

Anderson then tells him that the numbers of the types missing from Folklore Fellows Communications volume 74, that is the Aarne-Thompson catalogue (1928), will be determined by Mr. Thompson himself, who is now preparing a new edition of his catalogue. He then continues: "To facilitate your work, I intend to review your Rondallistica in order to complete the index I have published in the Swiss archives of folk traditions". ${ }^{47}$ He concludes: "I look forward with great interest to receiving the collections of Catalan folktales that you have been kind enough to tell me about". ${ }^{48}$

Anderson's involvement in Amades's classification of Catalan folktales was so important that Amades must have proposed to him that both men appear as joint authors of the future catalogue, because in his letter dated 12 September 1957 Anderson says:

As for your suggestion, I will with great pleasure do everything to help you in your undertaking, in which I take great interest. Send me all the cards and all the questions you would like and I will resolve and explain as much as I can. However, I cannot allow my name to appear next to yours on the frontispiece of your catalogue: this would only be possible if we were in daily contact and able to personally discuss all the matters related to this work; there are points regarding the cataloguing of folktales on which the greatest specialists do not agree. I would have to check all of your work, which is impossible. But you can certainly mention and specify my collaboration in the prologue. ${ }^{49}$

In his letter dated 23 October 1957, Anderson continues to express his willingness to help Amades with his cataloguing. He tells him once again that he will check the cataloguing of Amades's folktales published in the journal Schweizeriches Archiv für Volkskunde (Anderson 1954) so that Amades can use it in his catalogue. He also expresses his conviction that it will not be difficult 
to find a publisher for a catalogue that is "so desired by specialists", and says that he will do everything possible to help Amades. Finally he concludes that the preparation of the new edition of the Aarne-Thompson catalogue will still require many months of work.

On 4 December 1957, Anderson writes to Amades to tell him that he has received the three letters and the precious parcel of books, and that he is profoundly grateful for them. He then asks Amades to excuse his delay in responding to him and explains that it is because he wanted to include some of the classifications that he had promised Amades in his reply. He says that he has already classified the tales that Amades had sent him earlier and that he will attach the notes to the folktales of Serra i Boldú.

Anderson is as good as his word because in his next letter, dated 16 December 1957, he sends Amades his classification of the eighteen volumes of Rondalles populars (Serra i Boldú 1930-1933) and the volume Rondalles meravelloses (Serra i Boldú 1924). In this letter, Anderson advises Amades on a system to follow when preparing the catalogue. He says that the most useful system is the one used by Delarue, which requires an analysis of every version of each type, but he says that this system requires an enormous amount of work and would delay the publication of the book. He therefore advises Amades to restrict himself to making brief summaries of each type, as in the Aarne-Thompson catalogue (1928), but without including any lengthy analyses. We must therefore assume Anderson's recommendation for each type is a representative summary of all the versions rather than a detailed analysis based on sequences and motifs.

On this point, it is interesting to note that Anderson's recommendation mirrors the criterion used in the latest revision of the international catalogue (Uther 2004); that is, the use of a general overview for each type rather than a detailed description of sequences and motifs. This criterion has also been followed in the Catalan catalogues by Oriol and Pujol (2003, 2008).

Anderson then warns him that if only one version of a folktale is known, it is doubtful whether it should be catalogued. According to Anderson, "it is very often a combination of traditional (or non-traditional) motifs, a free composition by a narrator (a compiler or editor)" ${ }^{50}$

This fruitful collaboration continues in the following letters. Amades sends Catalan folktales to Anderson, who then catalogues them and in return gives Amades some advice on cataloguing (see Figure 13). For example, in the letter dated 30 January 1958, he recommends that Amades reserve space in his catalogue for fables, provided that these stories really exist in the Catalan oral tradition. To reinforce this criterion, he says that Aarne and Thompson included many of Aesop's fables in their catalogue, and as examples, cites types 34,41 , $50,51,57,60,61,62$, and 70 , among others. 
[Dau Bertràn y Bros], Les rondalles potuI. II. Barcelond 1908.1909.

- I p.1-16 [ns.I], se fill de l's". Anuth 301 s.

- Ifr.1T-32 Lur. II]" Les tres filles del rey". Aath 956 B

- In.33-44[ns. III] "El nen y las nena més bonichs que'l sot que'ss enllemena". Atagh 70\%

$x$ Ip. 45-48[m. VI], El reuch de les bueisees" Lua léyende de l'honme transformé en âne. que j'ai étudiée.

- Ifr.49-64 [nr. VI \&ls tres fretendents". Aasth $654+655$.

- If.65-72 [m. III "El gat del gegant". stasth $311+665 I$.

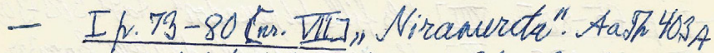
(t mo motif due type tath 408: "El sol y la serene fa tornar la gent morend").

- Ifr.81-86 [m. DIII]. El friencep serpent". Atatr $480+433+425$ (selor Sevatn: 425 B).

Figure 13. First page of Walter Anderson's catalogue of the Les rondalles populars catalanes by Pau Bertran i Bros, annex to the letter from Walter Anderson to Joan Amades, dated 30 October 1958. Fons Amades: Centre de Documentació de Cultura Popular de la Generalitat de Catalunya, Barcelona.

\section{THE CATALOGUE OF ETIOLOGICAL LEGENDS}

The process of cataloguing Catalan folktales and Anderson's guidance with regard to the materials that needed to be included made it clear to Amades that he should also publish a catalogue of etiological legends, and once again Anderson acted as a mentor to Amades.

In his letter dated 12 September 1957, Anderson explains to Amades that most national catalogues of etiological and historical legends have been published in the appendices to various folktale catalogues. These include the ones by Aarne (1918, 1920), Qvigstad (1925), Loorits (1926), and Sinninghe (1943), 
and for the German legends about giants, the catalogue by Höttges (1937). In his next letter dated 21 September 1957, he recommends the system used by Loorits (1926) for etiological legends, although he says that those used by Sinninghe (1943) and Aarne (1918, 1920) are also highly recommendable. He then continues that, to assist Amades, he has translated the titles of the first 59 types by Loorits into French, as well as the abbreviated titles of types 60 to 127. Anderson includes these lists in an appendix to the letter.

Amades must have been considering publishing the catalogue in French, as in his letter dated 23 October 1957, Anderson says:

When talking about animals, plants, etc., you should use the French nomenclature; if they are unusual and special terms that do not appear in the dictionary, you can use the Catalan word, followed in brackets by 'a type of...' Latin scientific names are useful, but not essential. ${ }^{51}$

Amades was probably considering publishing the catalogue of etiological legends as a separate book from the catalogue of folktales, because in his letter dated 11 April 1958, Anderson says that etiological and religious legends and tales about treasures should be catalogued, but that it is quite a difficult task and that a catalogue of that type could be published together with the catalogue of folktales, like those by Loorits (1926) and Sinninghe (1943), or as part of a separate book.

\section{EPILOGUE}

The task of cataloguing Catalan folktales was interrupted by the death of Amades in 1959. Anderson tried to continue the work and even raised the subject at the conference held in Kiel-Copenhagen in 1959. That conference discussed a proposal by Anderson to preserve the work done and ensure the completion of the catalogue. However, despite general support for the proposal, the difficulty of accessing Amades's materials and the fact that Anderson died three years later meant that the project was never completed (Oriol 1999: 383-384). Consequently, Stith Thompson's revision of the international catalogue published in 1961 was therefore only able to include Anderson's cataloguing (1954) of the Catalan folktales contained in the volume Folklore de Catalunya: Rondallistica (Amades 1950).

Fortunately, the last thirty years have seen renewed interest in the cataloguing of Catalan folktales. Josep Antoni Grimalt (1975) studied and catalogued the Majorcan folktales collected by Antoni M. Alcover, and Josep M. Pujol (1982) did the same for the other collections of Catalan folktales that had been published 
up to the end of the 1970s. Both studies were conducted in accordance with the guidelines of the second revision of the Aarne-Thompson catalogue (1961).

In 2000, Carme Oriol and Josep M. Pujol undertook the project of cataloguing all the Catalan folktales. To date, the most important results of the project have been: the Índex tipològic de la rondalla catalana (Oriol \& Pujol 2003), which is cited in the latest revision of the international catalogue, The Types of International Folktales (Uther 2004); the Index of Catalan Folktales (Oriol $\&$ Pujol 2008), a revised and expanded version of the previous catalogue, published in English and adapted to changes in the latest revision of the international catalogue (Uther 2004); and the multilingual website RondCat (http://rondcat.arxiudefolklore.cat/), which enables data on Catalan folktales to be constantly updated. As a result, the cataloguing of Catalan folktales, in which Amades and Anderson were key figures in the 1950s, has finally come to fruition and been presented to the international research community, just as the two folklorists would have wished.

\section{CONCLUSIONS}

The letters sent to Joan Amades by Walter Anderson provide us with first-hand knowledge of interesting aspects regarding the history of folklore because they cover topics that are related to the life and works of both folklorists.

The letters show that they collaborated to a remarkable degree. Amades provided Anderson with Catalan versions of folktales that he was able to use in his comparative studies. For his part, Anderson rated very highly the abundant corpus of Catalan folktales, and especially the book Folklore de Catalunya: Rondallística (Amades 1950).

The letters also enable us to follow how the cataloguing of Catalan folktales has evolved over the years, and to see the crucial role played by Anderson early on in the process. Anderson advised his Catalan colleague on how to determine what constituted a folktale, what criteria should be adopted when cataloguing, how to create international indices, how to approach the cataloguing of folktales, and how to deal with legends. Moreover, Anderson himself also undertook a thorough cataloguing of the Catalan folktales collections available to him, from Folklore de Catalunya: Rondallistica (Amades 1950) to those sent to him by Amades.

In addition, the letters provide other details relating to the publications that were exchanged by the two folklorists, the working materials they sent each other, their intention to participate in international conferences where they would have met, etc. In summary, the letters reflect the extensive collaboration 
between two exceptional folklorists who both possessed a remarkable capacity for work and who established a personal and professional relationship based on mutual respect and admiration.

\section{ACKNOWLEDGEMENTS}

This study is part of the research by the Grup de Recerca Identitats en la Literatura Catalana (GRILC), established by the Catalan Government (2014 SGR755) and was conducted as part of a project on Catalan folk literature, which received funding from the Spanish Government's Ministry of Economy and Competitiveness (FFI 2012-31808).

\section{NOTES}

1 For more biographical information on Anderson, see Järv (2008), Levin (1963), Ranke (1962, 1977), Seljamaa (2005), and Thompson (1996: 261, 333).

2 On the biographical details of Amades, see Calvo (1990) and Oriol (2008).

3 I am very grateful for the help provided by Veronica Guarch, Antoni Serés, and Marcus Yáñez when consulting the archives of Joan Amades.

4 Some years ago, I conducted a thorough investigation in an attempt to locate the letters that Amades wrote to Anderson. After finding that they were not in Barcelona with the rest of Amades's correspondence, I subsequently contacted Anderson's family, with the help of Professor of Romance Philology at the University of Kiel, Phil Helmut Lüdtke, and was informed that they did not have them either. In a letter written from Brühl on 7 April 1998, Mrs Helene Anderson told me that this correspondence had not been preserved because she had passed on all Anderson's documentation to the folklorist Kurt Ranke, who had been Anderson's disciple and a lecturer at the University of Kiel. Finally, I was also unable, despite the help of Hans-Jörg Uther, to find the letters in the archives of the Enzyklöpadie des Märchens (Göttingen, Germany), which houses the Kurt Ranke archives. Although my efforts to locate Amades's correspondence were ultimately unsuccessful, I am nevertheless very grateful to all of these individuals for their assistance and for the efforts they made on my behalf at that time.

5 Throughout this paper, I have given English translations for the excerpts from the letters in the text, and supplied the original French in the endnotes. The originals of the letters can be consulted in Oriol (2014).

${ }^{6}$ On Walter Anderson and the historic-geographic method, see Chesnutt (1996).

7 Je comprends le catalan et l'espagnol, mais je ne connais pas ces deux langues assez bien pour en faire usage dans mes lettres.

8 Letter dated 18 January 1953. 
9 Letter dated 7 August 1957, to which Anderson attaches 18 pages containing the catalogue of the folktales in the first fifteen volumes of the Alcover collection (1936-1972).

${ }^{10}$ Amades (1950, No. 93: 229-231).

${ }^{11}$ Amades (1950, No. 173: 416-420).

12 This folktale has no catalogue number in the international type index (Uther 2004). C-011 is the internal number given on the RondCat website for those types found during the cataloguing of Catalan folktales that are not included in the international catalogue.

${ }^{13}$ Clatell, derived from the older clotell, is probably a diminutive of clot (hole), as applied to the small cavity at the occiput (Coromines 1986: 741-743). The origin of the word clot is obscure, and is probably pre-Roman (ibid.: 765).

${ }^{14}$ Quant aux trois ouvrages que vous désirez voir, je ne puis vous en envoyer mes propres exemplaires, car ceux-ci ont été anéanti (ainsi que tous mes livres et tous mes manuscrits) pendant le siège de Koenigsberg (1945); pourtant vous recevrez bientôt ces trois livres de la part du commissionnaire de l'Académie des Sciences de Finlande, et je vous prie de les accepter comme témoignage de ma reconnaissance.

${ }^{15}$ La Fédération des Folkloristes qui vous intéresse est une organisation bien étrange: une organisation sans président, sans commissions, sans filiales, sans budget, sans séances, sans procès-verbaux, sans comptes-rendus.

${ }^{16}$ La Fédération est quelque chose comme la "république des savants" imaginée par Erasme de Rotterdam: on en devient membre en déclarant (ou même en montrant) qu'on est prêt à aider les autres folkloristes dans leurs études - et maintenant vous en êtes membre au même titre que moi. Si quelque folkloriste a besoin de matériaux folkloriques catalans, je lui donnerai votre adresse - de même que je l'ai reçue de la part de M. Paul Delarue. Et si vous-même vous aurez besoin de quelques matériaux, de renseignements bibliographiques etc., moi et tous les autres folkloristes, nous serons heureux de pouvoir vous servir à cet égard. C'est tout; il n'y a pas de formalités, il n'y a pas de listes de membres. - Moi-même, je suis membre du comité de rédaction des FF Communications (le seul comité de la Fédération!), c'est-à-dire de la série éditée au nom de la Fédération des Folkloristes et financée par l'Académie Finnoise des Sciences; depuis 1926 mon nom, à côté de cinq autres noms, figure sur les couvertures de tous les volumes de cette série (il y en a déjà 60, formés par 144 numéros); et cependant ni moi ni mes cinq collègues (parmi lesquels le prof. Martti Haavio est le chef) ne possédons aucun document qui atteste notre qualité de rédacteurs (ou même de membres de la Fédération)!.

${ }^{17}$ Consol Mallofrè made clear her interest in stamp collecting to Antoni Serés during a visit he made to her home. I thank Antoni Serés for providing me with this information.

18 This congress is also cited on the website of the Joan Amades Association (http:// joanamades.cat/la-postguerra-la-internacionalitat-i-les-grans-obres-1940-1959/, last accessed on September 18, 2015).

${ }^{19}$ A la fin du mois de juin j'espère de vous faire une visite à Barcelone. C'est que j'ai l'intention de me rendre à un congrès qui aura lieu à Porto du 18 au 23 juin (Coló- 
quio de estudos etnográficos "Dr. José Leite de Vasconcelos"). J’y irai (si la situation politique le permettra) via Irún, mais en retournant je passerai par Barcelone, où j’ai l'intention de m'arrêter pour un ou deux jours.

${ }^{20}$ Seljamaa (2005: 159) says that Anderson may have begun work on the monograph when he was a lecturer at Königsberg (between 1940 and 1945).

21 (1) Est-ce que le géant tient les yeux ouverts en dormant (et fermés en veillant), ou non? (2) Est-ce que la vieille sorcière enfonce l'aiguille enchantée dans une oreille de la fille, ou dans un autre endroit de sa tête? (3) Est-ce que la fille est métamorphosée en colombe, ou en un autre oiseau? (4) Est-ce que la sorcière promet au prince de devenir belle de nouveau, ou non? (5) Est-ce que l'oiseau vient trois fois dans le jardin du prince pour parler au jardinier, ou non? (6) Si c'est ainsi: quelles sont les paroles de l'oiseau et du jardinier?

${ }^{22}$ The Engravings and Images Department of the Museu d'Indústries i Arts Populars at the Poble Espanyol, of which Amades was the director, was housed in the building of the Arxiu Històric Municipal de Barcelona. The unpublished versions sent by Amades must have come from this archive.

${ }^{23}$ This manuscript has been of great assistance to researchers carrying out subsequent studies of the folktale The Three Oranges, for example Goldberg (1997) and Shojaei Kawan (2000 and 2002).

${ }^{24}$ Les organisations nordiques des folkloristes dont vous parlez ne sont pas des sociétés spéciales: ce sont des archives où tous les matériaux folkloriques d'une nation (imprimés ou manuscrits) sont recueillis et conservés. Il y a de telles archives à Copenhague, à Oslo, en plusieurs endroits de la Suède, à Helsinki, à Tartu, à Riga. En Allemagne on peut mentionner les archives des chansons populaires à Fribourg et des contes populaires à Marbourg. Même la grande "Fédération des Folkloristes" internationale n'est pas une vraie société concrète: c'est plutôt une ligue idéale de tous les folkloristes du monde qui se sont promis de s'entr'aider dans leurs études.

${ }^{25}$ La connaissance de votre belle langue est malheureusement trop peu répandue dans le monde.

${ }^{26}$ On the subject matter covered by Anderson in his paper, see Oring (1984).

${ }^{27} \mathrm{Il}$ y a plus de trente ans, j'avais établi la thèse que chaque homme qui récite un conte populaire l'a entendu lui-même non pas une seule fois dans sa vie, mais presque toujours plusieurs fois et de la bouche de plusieurs personnages; autrement le conte s'altérerait et se déformerait de plus en plus, ainsi que bientôt il ne serait plus à reconnaître.

${ }^{28}$ Cette thèse fut combattue par beaucoup de folkloristes, qui ne voulaient pas y croire.

${ }^{29}$ Pour décider la question, je lus une légende (peu connue) à trois étudiants de notre université, en les priant de l'écrire le jour suivant ainsi comme ils s'en souviendraient alors, et de la lire chacun à un autre étudiant, qui un jour après ferait la même chose; et ainsi de suite douze fois. En résultat j'eus trois séries, de 12 textes chacune, et les derniers textes de ces séries (A12, B12, C12) étaient tous affreusement déformés et divergeaient entre eux complètement; c'était précisément ce que j’avais prévu. Il y a une vingtaine d'années, j'avais fait quelques expériences analogues en Estonie (sans en publier les résultats); les résultats avaient été absolument identiques. 
${ }^{30}$ It is unclear whether Amades sent him this first edition (Amades 1948-49) or the second, which was also published in two volumes in 1953.

${ }^{31}$ Letter dated 18 January 1953.

${ }^{32}$ Letter dated 11 February 1954.

${ }^{33}$ Letter dated 11 February 1954.

${ }^{34} \mathrm{La}$ lecture de votre grand livre me fournit beaucoup de surprises. En lisant le conte $\mathrm{N}^{\circ} 231$ "L'home tornat ruc", je fis vraiment "des yeux comme des oranges": c'est un conte répandu en Allemagne depuis la Guerre des Trente Ans (parmi ses versions, il y en a deux du XVIIe siècle), un conte qui est probablement emprunté au roman d'Apulée, et que je connaissais très bien, puisque je l'avais étudié il y a plus de quarante ans! Mais je n'avais pas la moindre idée que ce conte fût connu aussi chez d'autres peuples - et surtout chez les Catalans!

${ }^{35}$ Letter dated 4 April 1953.

36 Je suis bien étonné de lire que vous avez recueilli tant de contes et de chansons populaires: 15.000 - c'est un nombre colossal!

${ }^{37} \mathrm{Si}$ un spécialiste se met à y chercher des versions d'un certain conte populaire - comment les pêchera-t-il de l'océan du livre catalan? Des versions d'un même conte s'y trouvent souvent dispersés en différents lieux - par exemple de véritables contes de fées (grâce à une localisation accidentelle) dans le chapitre des légendes de châteaux. Est-ce que le spécialiste doit imiter mon exemple en sacrifiant plusieurs semaines à l'étude du livre catalan? Ce n'est pas une chose que chacun puisse faire! Pour remédier, au moins en partie, à ce mal, j'indique dans la table suivante les numéros, sous lesquels le lecteur trouvera les contes-types registrés par Aarne et Thompson.

${ }^{38}$ Quant à la définition de ce qui est un conte populaire, je confesse de me soucier assez peu de définitions et classifications - en tout cas moins que vous qui êtes un compatriote de Raymond Lulle. Dans l'univers il y a tant de choses qui résistent à une définition rigoureuse, tant de formes de transition ou hybrides qui ne peuvent être classées. Moi j'appellerais un "conte" tout récit de ce qui s'est passé une fois, mais non pas de ce qui se passe beaucoup de fois à présent. Bien des peuples sauvages croient que pendant chaque éclipse le soleil ou la lune sont dévorés par un monstre et sortent puis de son ventre: ce n'est pas un conte, c'est une croyance. Le peuple russe dit que la terre repose sur trois baleines gigantesques, dont les convulsions causent les tremblements de terre: cela aussi, c'est une croyance, ce n'est pas un conte. Mais il y a aussi des peuples qui croient qu'au temps jadis il y a eu au ciel dix soleils qui brûlaient la terre sans pitié, jusqu'à ce qu'un héros en tua neuf par ses flèches: ceci, c'est un conte véritable - un conte étiologique.

Il y a des contes qui expliquent l'origine d'un proverbe ou d'une devinette, ou bien d'un surnom moqueur: tout cela, ce sont toujours des contes; mais par exemple les jeux de doigts ne le sont pas: ce sont plutôt de petits drames que de contes. Je ne classerais pas parmi les contes non plus les problèmes mathématiques (par exemple celui des 100 oies: $x+x+1 / 2 x+1 / 4 x+l=100$ ), ni les textes que vous appelez "embarrassallengues".

${ }^{39} \mathrm{Je}$ ferai tout mon possible pour vous le procurer dans quelques semaines. 
${ }^{40}$ Vous avez raison: la composition d'un catalogue national de contes populaires est un travail extrêmement utile, mais aussi très grand et très difficile.

Il faut enregistrer, si c'est possible, tous les contes populaires, bien qu'ils aient été publiés dans des almanachs, des revues, des journaux etc., et même ceux qui sont restés non-publiés; aussi ceux qui furent imprimés dans des livres d'enfants, pourvu que ce ne soient pas des remaniements artificiels de textes déjà enregistrés dans votre catalogue.

Pourtant il ne faut pas tenir compte des légendes locales sur les fées, les géants, les sirènes etc., sur les pays et les vaisseaux fabuleux, ni des légendes sur les vies des saints ou sur des miracles religieux. Ce sont là des choses très intéressantes, mais qui exigent un catalogue spécial.

Quant aux anecdotes et facécies, il faut en enregistrer le plus grand nombre possible - au moins toutes celles qui sont nommées dans le catalogue d'Aarne et Thompson. Pourtant les anecdotes purement locales (sur le blason populaire, etc.) pourraient être omises, de même que les interprétations du chant des oiseaux et les problèmes mathématiques.

${ }^{41}$ En lisant votre grand recueil, je n'ai point enregistré tous vos contes, mais seulement ceux qui figurent dans le catalogue d'Aarne et Thompson, et ceux qui y manquent, mais sont d'ailleurs très connus et importants. Tout ceci j'ai imprimé dans mon compterendu.

Anderson's review (1954).

${ }^{42} \mathrm{Si}$ vous avez des doutes sur quelque conte populaire, envoyez-m’en un bref résumé ou bien le numéro correspondant de votre Rondallística, et je vous en dirai mon opinion.

${ }^{43}$ En général, je ferai tout mon possible pour vous secourir dans votre entreprise.

${ }^{44}$ On the early work to catalogue the Alcover folktales, see Oriol (2001).

${ }^{45}$ On the steps that Amades took to obtain the materials that needed cataloguing, see Oriol (1998, 1999, 2001, and 2012).

${ }^{46}$ Vous me priez de vous expliquer bien clairement, quels contes sont exclus du système d'Aarne-Thompson. Hélas! C'est presque impossible; il faudrait un nouveau Raymond Lulle pour vous fournir toutes les définitions, distinctions et classifications que vous désirez. On peut seulement dire en général que les légendes religieuses, bibliques, étiologiques, historiques et locales sont exclues de ce système-là; pour tous les contes de ces genres on compose des catalogues à part.

${ }^{47}$ Pour faciliter votre travail, j'ai l'intention de faire une révision de votre Rondallística pour compléter l'index que j'en ai publié dans les Archives suisses des traditions populaires.

48 J'attends avec grand intérêt les recueils de contes catalans que vous avez eu la bonté de m'annoncer.

${ }^{49}$ Quant à vos propositions, je ferai avec le plus grand plaisir tout le possible pour vous aider dans votre entreprise, à laquelle je prends beaucoup d'intérêt. Envoyez-moi toutes les fiches et toutes les questions que vous voulez, et j'arrangerai et j'expliquerai tout ce que je pourrai. Pourtant je ne puis consentir à ce que mon nom apparaisse à côté du vôtre sur le frontispice de votre catalogue: ce serait possible seulement si nous pouvions entretenir un contact quotidien et conférer personnellement sur toutes les 
questions qui s'élèvent pendant un tel travail; quant à la classification des contes populaires, il y a des points à l'égard desquels les plus grands spécialistes ne sont pas d'accord l'un avec l'autre. Je devrais donc contrôler tout votre travail, ce qui est impossible. - Mais vous pouvez, sans doute, mentionner et préciser ma collaboration dans la préface de votre livre.

${ }^{50}$ C'est trop souvent une combinaison accidentelle de motifs traditionnels (ou non-traditionnels), une libre composition de quelque conteur (ou même de quelque collectionneur ou éditeur).

${ }^{51}$ En parlant des animaux, des plantes, etc., vous devriez faire usage de la nomenclature française; s'il s'agit de termes rares et spéciaux qui manquent dans les dictionnaires, vous pouvez conserver le nom catalan, en y ajoutant entre deux parenthèses: (une espèce de...). Les noms latins scientifiques sont utiles, mais non pas indispensables.

\section{MANUSCRIPT SOURCES}

Collected letters of Walter Anderson (1953-1958) from the Amades archive (Fons Amades. Centre de Documentació de Cultura Popular de la Generalitat de Catalunya, Barcelona).

\section{REFERENCES}

Aarne, Antti 1918. Estnische Märchen- und Sagenvarianten. FFC 25. Helsinki: Suomalainen Tiedeakatemia.

Aarne, Antti 1920. Finnische Märchenvarianten, Ergänzungsheft I. FFC 33. Helsinki: Suomalainen Tiedeakatemia.

Aarne, Antti \& Thompson, Stith 1928. The Types of the Folktale: A Classification and Bibliography. FFC 74. Helsinki: Suomalainen Tiedeakatemia.

Aarne, Antti \& Thompson, Stith 1961. The Types of the Folktale: A Classification and Bibliography. FFC 184. Helsinki: Suomalainen Tiedeakatemia.

Alcover, Antoni M. 1936-1972. Aplec de Rondaies Mallorquines d'En Jordi des Racó. 24 vols. Ciutat de Mallorca: Moll.

Amades, Joan 1948-1949. Les cent millors rondalles populars. 2 vols. Barcelona: Selecta.

Amades, Joan 1950. Folklore de Catalunya: Rondallística (Rondalles-TradicionsLlegendes). Barcelona: Selecta.

Amades, Joan 1950-1956. Costumari català. 5 vols. Barcelona: Selecta.

Amades, Joan 1951. Folklore de Catalunya: Cançoner (Cançons-Refranys-Endevinalles). Barcelona: Selecta.

Amades, Joan 1957. Contes Catalans. Contes des cinq continents 3. Paris: Erasme.

Anderson, Walter 1923. Kaiser und Abt: Die Geschichte eines Schwanks. FFC 42. Helsinki: Suomalainen Tiedeakatemia.

Anderson, Walter 1925-1926. Die Marspanik in Estland 1921. Zeitschrift des Vereins für Volkskunde, Vol. 35-36, pp. 229-252. 
Anderson, Walter 1937. Kettenbriefe in Estland. Eesti Rahvaluule Arhiivi toimetused 7. Tartu: n.p.

Anderson, Walter 1951. Ein volkskundliches Experiment. FFC 141. Helsinki: Suomalainen Tiedeakatemia.

Anderson, Walter 1954. Eine katalanische Märchensammlung. Schweizeriches Archiv für Volkskunde 50, pp. 57-62. Available at http://retro.seals.ch/digbib/ view2?pid=sav-001:1954:50::63, last accessed on November 19, 2015.

Anderson, Walter 1956. Eine neue Arbeit zur experimentellen Volkskunde. FFC 168. Helsinki: Suomalainen Tiedeakatemia.

Anderson, Walter 1960. Volkserzählungen in Tageszeitungen und Wochenblättern. In: W. D. Hand \& G. O. Arlt (eds.) Humaniora: Essays in Literature, Folklore and Bibliography, Honoring Archer Taylor on his Seventieth Birthday. Locust Valley, N.Y.: J. J. Augustin, pp. 58-68.

Calvo, Lluís 1990. Joan Amades i Gelats, biografia. In: Antoni Anguela \& Lluís Calvo (eds.) El món de Joan Amades. Barcelona: Departament de Cultura de la Generalitat de Catalunya, pp. 111-191.

Chesnutt, Michael 1996. The Great Crusader of Diffusionism: Walter Anderson and the Geographic-Historical Method. In: Ülo Valk (ed.) Studies in Folklore and Popular Religion, Vol. 1. Papers Delivered at the Symposium "Walter Anderson and Folklore Studies Today". Tartu: University of Tartu, pp. 11-26.

Coromines, Joan 1986 [1981]. Diccionari etimològic $i$ complementari de la llengua catalana, Vol. 2. Barcelona: Curial.

Goldberg, Christine 1977. The Tale of the Three Oranges. FFC 263. Helsinki: Suomalainen Tiedeakatemia.

Grimalt, Josep A. 1975. Classificació de les rondalles de Mossèn Alcover: Introducció a llur estudi. Doctoral thesis. Barcelona: Universitat de Barcelona.

Höttges, Valerie 1937. Typenverzeichnis der deutschen Reisen- und riesischen Teufelssagen. FFC 122. Helsinki: Suomalainen Tiedeakatemia.

Järv, Risto 2008. Anderson, Walter (1885-1962). In: Donald Haase (ed.) The Greenwood Encyclopedia of Folktales and Fairy Tales, Vol. 1. Westport: Greenwood Press, pp. 38-39.

Kalmre, Eda 2013. The Human Sausage Factory: A Study of Post-War Rumour in Tartu. Amsterdam \& New York: Editions Rodopi B.V.

Krohn, Kaarle 1910. Statuten des Bundes "FF". Erster Bericht über die Tätigkeit des folkloristischen Forscherbundes "FF". FFC 4. Helsinki: Suomalaisen Tiedeakatemian Toimituksia, pp. 15-16.

Levin, Isidor 1963. Walter Anderson. Deutsches Jahrbuch für Volkskunde, Vol 9. Berlin: Akademie Verlag, pp. 293-311. Available at http://digi-alt.ub.hu-berlin.de/viewer/ image/DE-11-001911673/307/, last accessed on September 21, 2015.

Loorits, Oskar 1926. Livische Märchen- und Sagenvarianten. FFC 66. Helsinki: Suomalainen Tiedeakatemia.

Oring, Elliott 1984. Experimentelle Erzählforschung. Enzyklopädie des Märchens, Vol. 4. Berlin: Walter de Gruyter, pp. 684-694.

Oriol, Carme 1990. Revision of Amades' Classification of the Catalan Folktales. Fabula, Vol. 31, Nos. 3-4, pp. 304-312. DOI: 10.1515/fabl.1990.31.3-4.304. 
Oriol, Carme 1998. Els rondallaris mallorquins, menorquins i eivissencs de l'Enzyklopädie des Märchens. Estudis de llengua i literatura en honor de Joan Veny, Vol. 2. Barcelona: Publicacions de l'Abadia de Montserrat, pp. 463-479.

Oriol, Carme 1999. El projecte de catalogació de la rondallística catalana en els anys 50. Actes de l'Onzè Col-loqui Internacional de Llengua i Literatura Catalanes. Palma (Mallorca), 8-12 de setembre de 1997. Barcelona: Publicacions de l'Abadia de Montserrat, pp. 365-386.

Oriol, Carme 2001. Els primers treballs catalogràfics de les Rondaies Mallorquines d'en Jordi des Recó. Estudis de llengua i literatura catalanes, Vol. 43. Miscel-lània Giuseppe Tavani 2. Barcelona: Publicacions de l'Abadia de Montserrat, pp. 185-201.

Oriol, Carme 2008. Amades, Joan (1890-1959). In: Donald Haase (ed.) The Greenwood Encyclopedia of Folktales \& Fairy Tales, Vol. 1. Westport: Greenwood Press, pp. 29-30.

Oriol, Carme 2012. Les primeres rondalles d'Enric Valor i la seva catalogació tipològica inèdita. Estudis de llengua i literatura catalanes, Vol. 65. Miscel-lània Albert Hauf 4. Barcelona: Publicacions de l'Abadia de Montserrat, pp. 201-213.

Oriol, Carme 2014. Édition de la correspondance entre les folkloristes Walter Anderson et Joan Amades. Estudis de Literatura Oral Popular / Studies in Oral Folk Literature, No. 3, pp. 49-84. DOI: http://dx.doi.org/10.17345/elop201449-84.

Oriol, Carme \& Pujol, Josep M. 2003. Índex tipològic de la rondalla catalana. Barcelona: Generalitat de Catalunya, Departament de Cultura.

Oriol, Carme \& Pujol, Josep M. 2008. Index of Catalan Folktales. FFC 294. Helsinki: Suomalainen Tiedeakatemia.

Pujol, Josep M. 1982. Contribució a l'índex de tipus de la rondalla catalana. Degree dissertation. Barcelona: Universitat de Barcelona.

Qvigstad, Just 1925. Lappische Märchen- und Sagenvarianten. FFC 60. Helsinki: Suomalainen Tiedeakatemia.

Ranke, Kurt 1962. Walter Anderson (1885-1962). Fabula, Vol. 5, unpaginated betw. 184-185.

Ranke, Kurt 1977. Anderson, Walter. Enzyklopädie des Märchens, Vol. 1. Berlin: Walter de Gruyter, pp. 493-494.

RondCat. Cercador de la rondalla catalana / Catalan Folktales Search Engine / Buscador del cuento folclórico catalán / Moteur de recherche des contes populaires catalans. Available at www.rondcat.arxiudefolklore.cat, last accessed on September 21, 2015.

Seljamaa, Elo-Hanna 2005. Walter Anderson: A Scientist beyond Historic and Geographic Borders. In: Kristin Kuutma \& Tiiu Jaago (eds.) Studies in Estonian Folkloristics and Ethnology: A Reader and Reflexive History. Tartu: Tartu University Press, pp. 153-168.

Serra i Boldú, Valeri 1924. Rondalles meravelloses. Barcelona: Editorial Catalana.

Serra i Boldú, Valeri 1930-1933. Rondalles populars. 18 vols. Barcelona: Políglota.

Shojaei Kawan, Christine 2000. Einige Gedanken zur internationalen Märchenforschung, anhand von drei Orangen. Volkskunde in Niedersachsen, Vol. 17, No. 1, pp. 41-54.

Shojaei Kawan, Christine 2002. Orangen: Die drei O. (AaTh 408). Enzyklopädie des Märchens, Band 10, pp. 346-355. Berlin: Walter de Gruyter. 
Sinninghe, Jacques R. W. 1943. Katalog der niederländischen Märchen-, Ursprungssagen-, Sagen- und Legendenvarianten. FFC 132. Helsinki: Suomalainen Tiedeakatemia.

Thompson, Stith 1932-1936. Motif-Index of Folk Literature. 6 vols. Bloomington: Indiana University Press.

Thompson, Stith 1996. A Folklorist's Progress: Reflections of a Scholar's Life. Edited by J. H. MacDowell \& I. G. Carpenter \& D. Braid \& E. Peterson-Veatch. Special Publications of the Folklore Institute, No. 5. Bloomington: Indiana University.

Uther, Hans-Jörg 2004. The Types of International Folktales: A Classification and Biography. FFC 284-286. Helsinki: Suomalainen Tiedeakatemia. 


\title{
IDENTITY CONSTRUCTION IN ARMENIAN MUSIC ON THE EXAMPLE OF EARLY FOLKLORE MOVEMENT
}

\author{
Brigitta Davidjants
}

\begin{abstract}
The aim of the article is to present various identity constructions in the early Armenian folklore movement. Armenian identity construction has been affected by various factors, including Armenia being the first country to adopt Christianity, and also the fact that it has a well-integrated diaspora in the West, both of which are used to present the 'Europeanness' of Armenians. Yet Armenia is surrounded by Muslim countries with which it shares many cultural similarities. Armenia has also been involved in various conflicts with its neighbours, starting with the Romans in the first century BC and ending with the Nagorno-Karabakh War between Azerbaijan and Armenia between 1988 and 1994. Due to these processes, the country is trying to distance itself from the East and, instead, belong to the West, and music can be used for the benefit of such identity construction. As an example, the article introduces various approaches to transcriptions of Armenian folk tunes that were made by composer and folklorist Komitas (Soghomon Soghomonian, 1869-1935), and folklorist Arshak Brutyan (1864-1936). Komitas is regarded as the most important figure in Armenian music. While transcribing folk tunes, he relied more on the Western way of thinking by standardising tunes according to the Western music system while Brutyan, on the other hand, tried to find transcription methods that would fit more with Armenian musical culture. Nowadays, unlike Brutyan, Komitas's ideas are still strongly advocated in Armenian academic circles, and he is respected for unifying Armenian music with Western European musical culture.
\end{abstract}

Keywords: cultural boundaries, early folklore movement, folk tune transcriptions, national identity construction

\section{INTRODUCTION}

In this paper, I will concentrate on national identity construction in the Armenian ethnomusicological discourse in light of the work of the composer and folklorist Komitas (Soghomon Soghomonian, 1869-1935), one of the founders of the discourse, and his contemporary, folklorist Arshak Brutyan (1864-1936). I will show how folk music transcriptions reflect different aesthetic preferences and methodological starting points, and how they can be related to national identity 
construction in general, as folk tunes formed in the past as well as today - an important part of creating a homogenous national identity. In describing those processes, I will analyse the same folk tune transcriptions that were carried out both by Komitas and Brutyan. According to my hypothesis, the former adopted his transcriptions according to the expectations of the Western audience, by simplifying the melodic, rhythmic, and metric elements of folk tunes, whilst the latter sought out methods from inside the culture he was researching by trying to mark down every single melodic and rhythmic characteristic in the tunes. The subsequent reception of Komitas and Brutyan by Armenian musicologists over the last hundred years contains a national identity construction that culturally positions Armenians within Europe. Partly due to that, unlike Brutyan, Komitas still maintains an important position in modern Armenian musicology.

Most of the Eastern European nations have created their own schools of national music in the Western tradition and Armenians are no exception. Armenian writing of national history through music writing emerged in the Russian area in the late nineteenth and early twentieth centuries and continued to develop in Soviet Armenia (Pahlevanyan \& Kerovpyan \& Sarkisyan 2001). In the Armenian national discourse, Komitas is considered to be the founder of Armenian national music. He was a composer, folklorist, musicologist, and music teacher at the time of the national awakening at the end of the nineteenth and beginning of the twentieth centuries. His musical activities brought Armenia closer to Europe: as a folklorist he worked towards the research and preservation of Armenian traditional music, while he also used this music according to the conventions of western national-romantic music. The story of Armenian music has presented Komitas almost as a mythical national hero. ${ }^{1}$ Even today he is the symbol of Armenian European cultural identity, although such a self-perception conflicts with regional realities. Armenia is historically divided into eastern and western Armenia. Since the nineteenth century, eastern Armenia was lodged within the Russian empire and now forms the modern Armenian Republic. The western part belonged to the Ottoman Empire and has been absorbed into eastern Turkey. In Armenian culture two branches can be distinguished, eastern and western, and both have their own dialects, culture, etc. (Samuelian et al. 2003: 26). Komitas lived mainly in today's Turkey, and his identity can be tied more to western Armenian traditions.

Brutyan was Komitas's contemporary and, at first sight, certain similarities can be traced between them. They both originated in the western Armenian region (modern north-eastern Turkey), but studied and graduated from the Gevorkian Theological Seminary in Vagharshapat in the east (today's Etchmiadzin), Brutyan in 1882 and Komitas in 1893. As was typical of the era, they 
were engaged in a large number of activities: they were music theorists, folklorists, and teachers, they developed choral singing, etc. For example, Komitas wrote multiple comparative research papers on traditional music, in which he generalised the traditional music of various nations (Geodakyan 1969: 48), while Brutyan compared Western and Armenian notations (Brutyan 1985: 15). Allegedly, Komitas and Brutyan also met at least once - according to Margarit Brutyan, the grand old lady of Armenian musicology and granddaughter of Arshak Brutyan - when Komitas and another composer, Kara-Mourza, arrived in Alexandropol (today's Gyumri) to give concerts. Brutyan worked there as a music teacher and he introduced them to his choirs for four voices (Brutyan 1985: 15-18).

Brutyan offers interesting material for comparison with Komitas. His position in Armenian musical life and in the history of Armenian music is different. Considering Komitas's role in Armenian musical life also as a composer, Brutyan's scope of activities was narrower, which did not bring him such a prominent position. Though highly appreciated by folk musicians and folklorists (Brutyan 1985: 8; Kushnaryov 1958: 5), he did not gain such public attention as Komitas. He has not been that well recognised by later musicologists, and he also did not form a separate school of folklore in Armenia. The reason might also be that he was more local in his activities and stayed mainly in Alexandropol where he is highly appreciated also today, and where a music school has been named after him. The difference between Komitas's and Brutyan's positions in Armenian ethnomusicology was reinforced and confirmed by later Armenian national music history writing, which evaluated Western concert and choral music more highly than folk music in itself, but perhaps also because Brutyan's transcriptions did not correspond to the ruling ideology of Europeanness.

This all makes it harder to explain Brutyan's position in Armenian folklore discourse, which is not ideologically so loaded as Komitas's, yet also carries a certain meaning. Today, his transcriptions are still used for practical purposes: through history, they have been taken as good examples of Armenian folk music and art of ashugh ${ }^{2}$ (Kushnaryov 1958); folk music students use them in their performances (according to my fieldwork at the Yerevan State Conservatory named after Komitas from 2002 to 2011), etc., yet there is no such discourse around him as around Komitas.

Brutyan was slightly older than Komitas and worked simultaneously with him, and yet they represented different musical worlds. When comparing Komitas's and Brutyan's folk tune transcriptions, one can notice a big methodological difference between approaches towards transcriptions. Their transcriptions reflect their different ways of musical thinking: which aspects either of the folklorists have emphasised, or on what they have concentrated while placing 
the musical material into the framework that originated in a culture different to that of Western tonal music. The analysis shows a difference in their cultural background according to which they observed and valued the collected material. This difference can be partially explained by Brutyan's probably unconscious denial of the ruling European identity construction in his folkloristic work. In his contrast, Komitas's ideological nature becomes particularly evident. This is something that has never been called in question in Armenian musicological discourse.

Yet in Armenian ethnomusicology new trends have also emerged since those days that include new transcription techniques. Beginning in the 1960s, more precise transcription methods were developed in Armenia, too, according to developments of ethnomusicology. Armenian musicologists started to use recordings for transcriptions, many additional marks came into use for marking down melody, they started to make textual analysis next to musical analysis, songs were transposed only exceptionally, etc. Those methods are still present in modern Armenian ethnomusicology (Pahlevanyan 2005: 25-30).

In the next chapter, a description is given of the methods being used in the current research, while in the following parts Armenian music is positioned on the boundaries between East and West. The theoretical background of this research is based on the discourses of post-colonial theorists (Homi Bhabha 1994; Benedict Anderson 2006; etc.), musicologists (Andy Nercessian 2000; Philip Bohlman 2001 [1999]; Carl Dahlhaus 1983 [1980]; etc.), and political scientists who have concentrated on Armenian topics (Ronald Grigor Suny 2001; Razmik Panossian 2002; etc.). The last chapter presents some comparative analyses of two folk tunes that were transcribed both by Komitas and Brutyan. The transcriptions are in the archives of the Charents Museum of Literature and Art in Yerevan, Armenia.

\section{METHODOLOGY}

The aim of the present analysis is to describe the different ideologies in early Armenian folklore movement that reflect themselves in approaches chosen for transcribing the same folk melodies. Such differences can result from different, perhaps hidden, unconscious ideologies, and reflect the cultural context of the two folklorist. By and large, the sociocultural model for studying music is used, in which both the research of the cultural context and comparative music analysis are applied.

Transcriptions are seen as cultural texts, and by analysing them and their cultural background I will highlight the common codes, ideologies, and 
discourses. I try to map what can be said about the individuals featured in the texts, and also how the texts are framed and presented. I am interested in which terms are used and what is their symbolic meaning, and what are the assumptions embedded in the musical texts. I will use the answers to the questions to build arguments about those who construct cultural products and wider social and cultural conditions (Davis 2008: 56).

My first step was to examine Komitas' ${ }^{3}$ and Brutyan's ${ }^{4}$ folk tune collections to discover general tendencies in their transcriptions, which would support my comparative analysis of folk tunes. More than a hundred songs by Komitas and the same amount by Brutyan were examined for having a representative sample of the texts that would help to make more extensive conclusions about the transcriptions. In general, the songs shared the same tendencies that characterised the songs chosen for comparative analysis. Transcriptions made by Komitas were generally without embellishments, the rhythmic picture was symmetric and the songs were both metrically and modally adjusted to correspond to the European discourse of folklorism in the late nineteenth and early twentieth centuries. Brutyan's transcriptions, on the other hand, were characterised by a very complicated rhythmic picture, melodies included many embellishments and were not modally so adjusted to European folklorist discourse.

As a background to Komitas's and Arshak Brutyan's folk tune collections, I also analysed other Armenian folk tune collections, to see which parameters other folklorists had concentrated on: metro-rhythmic, tonal, form, etc. ${ }^{5}$ Here I noticed a tendency that earlier transcriptions - until the first half of the twentieth century, for example by Spiridon Melikyan and Mihran Toumajian resembled more, both rhythmically and tonally, Komitas's transcriptions, yet in the second half of the twentieth century - those of Brutyan's. The latter was common, for example, to an important modern source, the prominent folk tune collection Talin: Zhoghourdakan yergery ${ }^{6}$, which was published in 1984. Rhythmical similarities became especially clear while comparing transcriptions of the same song, such as Le le yaman, by Brutyan and Komitas, and a version of Dle Yaman in Talin, although the latter was created around half a century later (Pahlevanyan 1984: 143-145).

To better understand Armenian folk tunes, I also transcribed and analysed living and recorded performances of folk tunes, to start with Hayrik Muradyan's recordings from 1958 to $1988,{ }^{7}$ and to end with Margarit Voskanyan's performances in 2013. ${ }^{8}$ The analysis was also supported with my own experience of performing Armenian music, and studying, living, and working in Armenia for more than ten years. As experience is central to cultural studies (Pickering 2008: 17), my own practical experience has offered me valuable insight into the performance of Armenian folk music. In other words, my own ethnographic 
observation has been useful as it has offered me an opportunity to document the actual processes and people involved in cultural production (Davis 2008: 58).

The majority of work was done in the archives of the Charents Museum of Literature and Art, with Komitas's archived materials (Archive collections Nos. 302, 303, and 304), and also those of Brutyan's (Archive collections Nos. 3 , 4 , and 5), searching for transcriptions of the same tunes that were made by both of them. I found four songs in which the musical material and lyrics largely overlapped, and compared their tonal, rhythmic, and formal structures, in addition to a few dozen songs that overlapped only to some extent. In the article, I will present the analysis of two of them, Chem chem and Le le yaman, which are both good examples of different approaches to interpreting folk tunes. For both songs, there is one version by Komitas and two versions by Brutyan, which makes a total of six transcriptions.

There is no information available as to where or when precisely these transcriptions were made. Komitas and Brutyan both lived and worked mainly in western Armenia, i.e. the Ottoman Empire. In general, it is known that all of Komitas's transcriptions were made between 1881 and 1913, mostly in the western Armenian area (Muradyan \& Atayan \& Tatevosyan 1956: 28-31), and some in eastern Armenia, i.e. in the Russian Empire (Shaverdyan 1989: 58). Brutyan started his work in the eastern Armenian area at approximately the same time (1879) (Brutyan 1985: 16).

Transcriptions of the same songs made by different folklorists in dissimilar places at different times may differ from each other due to regional features, variability, incidental deviations, etc. Even so, by juxtaposing the songs, an interesting picture of the transcribers unfolds, which reveals the interests and preferences of the folklorists, and the similarities and differences in their cultural background, the era's research methods, etc. Therefore, the transcriptions of the two songs illustrate more general tendencies that characterise the transcriptions of Komitas and Brutyan but - with the analysis of cultural context - also show how their meanings were produced later on in the Soviet era.

Names of places and people in Armenian are transliterated according to eastern Armenian pronunciation and orthographic rules, except the names of persons who originated from western Armenia, as there are minor differences between the two dialects. 


\section{SOME ASPECTS OF IDENTITY CONSTRUCTION IN ARMENIAN CULTURE}

In Armenian musicological literature, both the reception and transcriptions of Komitas and Brutyan - but also of many other Armenian folklorists - bring us to a larger topic of identity construction for Armenians. Identity is the representation of selected habits that are used for defining one's self to others (Turino 2004: 8), and there is an "atavistic belief that identities can be maintained and secured only by eliminating difference and otherness" (Wodak et al. 1999: 3). In Armenian culture, across the centuries, self-positioning towards the West has been common, which often includes creating boundaries and neglecting common ground with regional neighbours. Boundaries can be defined in several ways: geographically, culturally, politically, religiously, linguistically, etc. Armenians locate themselves geographically on the borderlands of East and West; they position themselves geographically in Asia, but as Christians they see themselves as a part of Europe. An essential element of their identity is antagonism towards pre-Russian colonisers who were mostly Muslims. Also today, Armenia is surrounded on three sides by Muslim countries: Azerbaijan, Turkey, and Iran. The idea of Europeanness is reflected in many fields, such as everyday politics and media, as well as arts and humanities. ${ }^{9}$ As one of the reformers of Armenian music according to the Western tradition, Komitas agrees well with the construction of cultural boundaries between Armenia and its Muslim neighbours.

The first important strategy for constructing Europeanness in Armenian identity is related to the adoption of Christianity in the fourth century after Christ (Panossian 2002: 126). Religion is a significant factor in Armenian identity construction. In the South Caucasus, before the Bolshevist Revolution in 1917, identity was shared primarily with co-religionists, rather than with a theoretically bounded territory as a homeland (Suny 2001: 873). In Armenia, Christianity is traced back to the missions of apostles Bartholomew and Thaddeus around AD 60. In AD 301, Saint Gregory the Illuminator converted Armenian king Tiridates III to Christianity, which was soon recognised as the state religion (Ter-Sarkisyants 2005: 136-179). According to legend, Christianity was adopted due to the miraculous convalescence of the king from madness. Yet the reason was probably political: Tiridates III had been informed that Roman Emperor Diocletian had negotiated with the Persian powers (the Sassanids) against the Armenians. As Christians had already been exerting a noticeable influence on Armenian society, the king decided to baptise himself, and Christianity became the official state religion (Panossian 2002: 126). 
Today, Armenians emphasise that they were the first Christian country in the world. They have an independent church, and they are "the defenders of Christianity at the frontiers of Islam" (Suny 2001: 885). The church has been an essential institution in establishing boundaries between Armenians and the 'others'. Particularly, in the diaspora, the church has organised life for centuries; it has been forming the community and preserving it. The church has helped to preserve rituals, foods, dances, and customs, which are all markers of diasporic identity (Yazedjian 2004: 44). The Armenian diaspora emerged first in Middle Eastern countries: during the existence of the Sassanid and Persian empires (Tololyan 2005: 37). The rise of modern diasporas in Western countries is also based on religion: the Armenian genocide of 1915 within the territory of the Ottoman Empire is interpreted in the light of a deep antagonism between Muslim Turks and Christian Armenians. It has to be mentioned that the refugees of the genocide did not form the first wave of the Armenian diaspora: living in diaspora was not new for the Armenians of the twentieth century. Certain waves of emigration can be distinguished in history and the earliest of them go back to the ancient period and the Middle Ages. However, the largest emigration to affect the modern Armenian self-consciousness took place at the beginning of the twentieth century (Adalian 2010: 271).

In the cultural resources of the classical diaspora, suffering experienced through forced exiles, persecutions, and finally genocide, is explained through religious theodicy (Smith 2010: 8). The figure of Komitas is interpreted as being a great example - he was a genocide survivor, and yet surviving is a relative term because after this experience Komitas lost his mind and spent the rest of his life in a nursing home in France (Poladian 1972: 83). According to Shaverdyan, the path trod by "Komitas [---] does not reflect so much, or solely, his personal destiny but rather the nation's" (Shaverdyan 1989: 20). ${ }^{10}$ Also, musicologist Georgi Geodakyan has written the following:

In the destiny of Komitas, on his thorny and tragic path, the whole historical epoch of the Armenian nation is reflected: the rise of national consciousness, struggles, emerging hopes, and the era that concluded with the terrible tragedy of 1915, overshadowed by the most horrible pages in the history of much-affected Armenia. Komitas drank to the bottom the bitter cup of suffering that was devolved to his nation. ${ }^{11}$ (Geodakyan 1969: 7)

So Komitas is included in the genocide discourse. The reception of Komitas reflects how secular nationalists found in ethnohistory resources in the struggle for raising Armenian consciousness and shows that where ethnic heroism is linked to Christian martyrdom, the nation is linked to religion (Smith 2010: 13-14). Komitas has become a martyr, the embodiment of various factors of 
the construction of the Armenian national identity, in which Western culture is contrasted against the Muslim Middle East - such approaches can be traced in most writings about Komitas. ${ }^{12}$ This way, the reception of Komitas shows how music is used in the construction of national ideologies which are especially evident in comparison with other folklorists, i.e. Brutyan in the current case.

\section{ARMENIAN MUSIC IN THE SERVICE OF WESTERN NATIONAL IDEAS}

Western-type Armenian composers appeared in the context of the nineteenthcentury national awakening, when national ideas spread progressively throughout Eastern Europe. The concept of nation was born in an age in which the Enlightenment and Revolution were destroying the legitimacy of the divinelyordained, hierarchical dynastic realm (Anderson 2006: 7), and the idea arose that instead of a dynasty one should be loyal to one's nation. Until the end of the eighteenth century, national style in music was largely a writing convention that a composer could select and change, rather than some inner ethnic character that was inherited at birth (Dahlhaus 1983 [1980]: 90). In the nineteenth century, however, national styles became associated with the ethnic origin.

Armenian musicians were no exception. After 500 years as part of the Persian and Ottoman empires, Eastern Armenia became part of Tsarist Russia (with some areas being taken from Persia in 1828, and others from Turkey in 1878). Armenian societies, cultural and educational centres and publishing houses arose not so much in the areas of modern Armenia, but also in Moscow, Tbilisi, St. Petersburg, Baku, Constantinople, Paris, Venice, Vienna, etc. Constantinople and Tbilisi became the most important centres of Armenian musical culture. Both centres had strong links with European musical culture - Constantinople primarily with France and Italy, while in 1846 Tbilisi itself became a provincial centre within the Russian empire (Pahlevanyan \& Kerovpyan \& Sarkisyan 2001; Samuelian et al. 2003: 26). ${ }^{13}$

Under those conditions, the new generation of Armenian musicians was brought up in the Western tradition and the role of the educated elite was decisive in the rise of nationalist ideas in Armenia. Their relationship to the old Armenian tradition was different. They started to evaluate their ancient culture from the 'outside'. At the same time, in search of musical materials and ideas for new national music it was natural for them to turn to Armenian folklore (Shaverdyan 1989: 40).

This school had nothing in common with earlier Armenian musicians: for centuries musical skills were passed from masters to their apprentices and 
singing was predominantly monodic, but the new musicians were educated in conservatories, and they spread polyphonic choral songs, formed orchestras, organised public concerts, etc. (Geodakyan 1969: 42, 48; Shaverdyan 1989: 47; Brutyan 1985: 15-16). Some younger musicians had studied in Europe, while some were taught by Russian composers who themselves had often received their education in Germany. For example, a composer of choral music, KaraMourza, had studied in Odessa and was one of the first to unify European composition techniques and Armenian folk tunes (Geodakyan 1969: 18). Makar Yekmalyan, who had a strong influence on Komitas, was Rimski-Korsakov's student and was therefore well acquainted with Russian ideas about musical nationalism (Geodakyan 1969: 36; Shaverdyan 1989: 66). Tigran Tchoukhadjian (1837-1898), who composed the first Armenian opera Anush, had studied in Milan; Nikoghayos Tigranyan (1856-1951) in Venice and St. Petersburg, etc. (Geodakyan 1969: 18; Pahlevanyan 2005: 21). Therefore it can be seen that Armenian Western-style interest towards traditional music positions itself towards the Russian sphere of influence, while ideas about collecting and studying folk melodies originate in German comparative musicology of the late nineteenth century.

Among them, Komitas is considered as one of the most important figures. Part of the reason might be that, compared to other early folklorists, he was international and extensive in his activities: he studied musicology in Germany, gave lectures at conferences in France and Turkey, he was member of the International Musical Society, etc. Brutyan, on the other hand, remained, for most of his working career, in Alexandropol. Komitas also travelled around Europe and communicated with European musicologists just at the time when the contemporary music history writing tradition was on the rise. Thanks to this serendipitous timing, Komitas promoted cultural values that later started to re-create his myth in the writings about Armenian history.

After completing his studies at the Gevorkian Theological Seminary in Vagharshapat in 1896, Komitas went to Berlin to study at the Kaiser Friedrich Wilhelm University and at the private conservatory of R. Schmidt. After graduating with a doctorate in musicology, he returned to Vagharshapat where he applied his knowledge to re-organise music studies. He formed an orchestra of western instruments and composed new music for the Armenian liturgy, Patarag (Geodakyan 1969: 48, 42; Shaverdyan 1989:47). Brutyan also received his education at the Theological Seminary in Vagharshapat, and his activities reflect the institutional changes of the period: he formed several schools and church choirs, composed Armenian polyphonic choral songs, and organised public concerts (Brutyan 1985: 15). 
Along with those new ideas, the movement towards collecting folk music developed, and was supported by the belief that the collective national spirit of people is the driving force in history (Dahlhaus 1983 [1980]: 81). Therefore, fieldwork became an important part of the Armenian national movement, and researchers studied their collections with methods acquired from their Western musical education. Transcriptions were based on authentic material, but the scores had to be understandable by the average Western musician or musicologist - those being the addressee of the research and publication. Folk tunes became 'museum pieces', something to conserve, exhibit, and use for composing music in the national style.

The Western audience was important for Komitas, as he had connections with international music institutions. From 1899, he belonged to the International Music Society. In 1906 and 1914 he gave lectures about Armenian traditional and church music at international musicological conferences in Paris (Muradyan \& Atayan \& Tatevosyan 1956: 26-32; Poladian 1972: 83). Also in Paris, he published his arrangements of folk tunes and organised concerts of Armenian music. Komitas also introduced Armenian music to Switzerland, Italy, Russia, etc. (Geodakyan 1969: 95; Shaverdyan 1989: 71). Komitas's own way of thinking was probably nation-centred, as he considered Armenian music to be something special. In an interview to the Armenian newspaper Azatamart in Constantinople, after returning from Paris in 1914, he emphasised that he had succeeded in convincing guests at the conference that Armenian music was of a high artistic value and that "it has been preserved in a more untouchable way than the music of some other nations" (Shaverdyan 1989: 305).

Komitas had also many students and friends who kept alive his memory and continued his school: composers Nikoghayos Tigranyan (1856-1951), Grikor Suni (1876-1939), Armen Tigranyan (1879-1950), Romanos Melikian (1883-1935), Anushavan Ter-Gevondian (1887-1961), Sargis Barkhudaryan (1887-1973), etc. (Muradyan 1960: 273-274), and folklorists Manuk Abegyan (1865-1944), Spiridon Melikyan (1881-1933), Barsegh Kanachian (1888-1967), Mihran Toumajian (1890-1973), and Vagharshak Srvandztian (1891-1958). Those folklorists were also characterised by more normative, European way of transcribing which was typical to the era and to the early folklore movement, and their transcriptions resemble more the transcriptions made by Komitas. ${ }^{14}$

Among Komitas's students, the most important input came from his pupil, musicologist Spiridon Melikyan. He studied under Komitas in Etchmiadzin, Armenian religious centre, and helped him at his work with the choir. Later, in 1904, Melikyan left for Berlin, where he stayed until 1908, to study with the same professors as Komitas. He transcribed folk tune transcriptions of Komitas 
from Armenian notation system, called Limondjian system, into the European one, and prepared the songs for publishing in 1931 (Melikyan 1949: 22-23).

Among Komitas's friends were many Armenian cultural figures who participated actively in creating Armenian national culture, for example poet Hovhannes Tumanyan, together with whom Komitas wanted to write the opera Anush. Another friend of Komitas' was literary scholar Manuk Abeghyan. Together with Komitas, he published in 1903 a collection of folk songs titled One Thousand and One Songs (Shaverdyan 1989: 61-62), which can be seen as an allusion to west and south Asian story compilation One Thousand and One Nights, which became hugely popular in Europe since the Enlightenment era and symbolises Orient.

When it comes to transcribing folk tunes, Armenian early folklorists mostly used their own notational system, one that was comfortable for transcribing monody, but which also carried strong national significance by being derived from the Armenian seventh-century notation, the khaz system. At the beginning of the nineteenth century music theorist Hampartsoum Limondjian (1768-1839) took some symbols from the khaz system and adapted them to the diatonic scale. ${ }^{15}$ The similarity between the new notation and the khaz system was just visual (Kushnaryov 1958: 351-356). In the second half of the nineteenth century, western notation also became widespread, as Limondjian's system was incomplete for writing polyphonic music (Atayan 1973: 168-186). Yet, the system was later used by many folklorists - also by Brutyan and Komitas - for transcribing monodic music. There was also an important ideological aspect concerning Limondjian's system. By the early nineteenth century, the khaz system had reached a crisis point as musicians no longer knew how to read it (Pahlevanyan \& Kerovpyan \& Sarkisyan 2001). By giving the symbols a new meaning, Limondjian hoped to preserve them in the memory of contemporary musicians (Kushnaryov 1958: 351-352). When it comes to the old khaz notation, one more aspect has to be noted. In Armenian musicological literature, it is often claimed that Komitas had almost discovered the key to reading the old khazes, but his work was destroyed in the genocide. ${ }^{16}$ Thanks to this, the claim has become a part of Komitas's reception, in which the genocide is linked to national heroism and martyrdom.

In the nineteenth century, there was a belief all over Europe that national spirit initially revealed itself in folk tunes and would later be embodied in the classical music of this national culture. Creating art music was seen as the aim of collecting and studying folk tunes and a perfect expression of the essential spiritual characteristics of the nation once embedded in folk music (Dahlhaus 1983 [1980]: 62). So, as in many other countries, folk tunes spread into Armenian art music. The intensity of the national message that was com- 
municated by composition was for a long time evaluated by a composer's level of skill in using folk tunes (Nercessian 2000: 85). Armenian composers, such as Kara-Mourza, Makar Yekmalyan, and also Komitas, composed arrangements of Armenian folk tunes (Muradyan 1960: 273-274). In larger choral and polyphonic compositions that required the musical development of folk materials, most composers followed Komitas's principles (ibid.): melody lines and voice parts were created using the modes and rhythmic patterns of a folk tune taken as the thematic material of a new polyphonic composition (Kushnaryov 1958: 599-603). This makes Komitas the key figure among Armenian composers as he laid the foundation for the polyphonic (Western choral) repertoire so that it sounded Armenian and preserved recognisable Armenian tunes (Muradyan 1960: 273-274). At the same time, Brutyan's most valuable achievement was his work as a folklorist; he collected not only Armenian folk tunes but also a wider and more Middle Eastern tradition, the ashugh art (Brutyan 1985: 17).

\section{CERTAIN PECULIARITIES OF ARMENIAN TRADITIONAL MUSIC}

In Armenian traditional music we find peasant folk music with its common genres, such as work songs, ritual songs, lyrical songs, dance songs, and instrumental music. But there are also various traditions of professional music. One of the oldest known traditions is the art of gusans. References to this tradition date back to sources from the fifth century. The tradition included narrators, singers, instrumentalists, dancers, and actors. Gusans were professionals performing to an audience and this art was handed on from a master to his disciples. In the seventeenth and eighteenth centuries, the art of ashugh that spread across Armenia shared some features of the art of gusans; however, there were certain differences in the form and content of their music as well as in their performance traditions. The name ashugh appears in many languages and comes from Arabic, meaning 'in love' (Pahlevanyan \& Kerovpyan \& Sarkisyan 2001). Ashugh art was largely based on the poetic formulas of Middle Eastern literature: it had much in common with the system of melodic modes used in Middle Eastern traditional music, i.e. Azeri mughams, and Persian and Arabian maqams, and it was often performed to the same audience (Kushnaryov 1958: 240-258; Pahlevanyan 2005: 33-34; Atayan 1965: 26-52). Ashugh art was both close and important to Brutyan, who lived in the ashugh centre of the nineteenth-century Alexandropol, and collected many ashugh songs (Brutyan 1985: 15-17). Komitas, on the other hand, according to the common narrative in Armenian musicological discourse, did not consider ashugh art to 
be 'true' Armenian music as it was strongly influenced by Middle Eastern art (Shaverdyan 1989: 106-107).

As for its structural features, Armenian music is firmly rooted in the traditions of the Middle East. Both secular and medieval religious music are monodic traditions. The scales are not based on dividing the octave and repeating the intervallic structure an octave higher or lower. In Middle Eastern and Caucasian music, vibrato, glissando, and tremolo are widespread and concern a different intonation of certain scale steps. Among Armenian singers, the most common ambit for vibrato are whole tone, semitone, or less. Vibratos with the ambit of third and sometimes fourth resembling tremolo also appear, but less frequently. However, these are common phenomena in Islamic musical culture and occur in the music of Armenian ashughs (Pahlevanyan 2005: 33-34), whose art crossed the borders of various states and empires. The rhythm in Armenian music is additive and rhythmic patterns of irregular duration follow each other, contrasting against the divisive rhythmic thinking in which a larger period of time is divided into smaller rhythmic units (Sachs 1953: 25).

While describing Armenian music, musicologists often use theoretical tools that are unambiguously associated with Western culture, which is very different from the culture of the Caucasus and the Middle East. Such an approach, which was particularly widespread before the era of sound recording, is problematic. Armenian traditional music has developed in the Middle Eastern sphere of culture, and contains phenomena that are structurally very different from Western classical music. For example, while describing the pitch structures of Armenian traditional music, all leading Armenian musicologists refer to its modal, diatonic structure. ${ }^{17}$ However, European modal scales have nothing to do with Armenian music, as they go back to the medieval church modes and belong to the European pitch structuring system. Later, during the height of national romanticism, they were performed on equal-tempered instruments.

Armenians are certainly not the only nation to apply the concept of diatonic scales when it comes to describing their traditional music. This was and still is a common practice in many countries in Eastern Europe, something that started in the nineteenth century, when Ukrainian researcher Sokalsky aimed to set all traditional music within the frames of Greek diatonic tetrachords (Spencer 2001: 625-626). In the atmosphere of national awakening, several structural features of the folk music (and poetry) of small nations were used to prove their origin in ancient civilisations and their honourably long history. The use of diatonic scales for describing different types of folk music and linking them with ancient European musical cultures stimulated national pride (Ambrazevičius 2006; Lippus 1988: 89, 91). This approach seems to apply also to the historical development of the theory of Armenian traditional music. The 
founder of this theory in Armenian music was again Komitas (Brutyan 1973: 226-228; Kushnaryov 1958: 11). This was one more of his many contributions to the European discourse in Armenian music theory.

There are also cognitive reasons that make descriptions of pitch structures in Armenian traditional music by projecting them on the diatonic scales unsuitable. The musical perception of many researchers, brought up in the Western tradition, often performs this transfer unconsciously when trying to analyse music in an unknown tuning system. Therefore, sometimes, analysis may rather blend the structure of music that it should explain, which was especially the case during the early folklore movement. It seems to be the case with Armenian music as well. Diatonic octave modes are applied in the analysis of melodies that use only part of the scale steps. However, several modes contain similar tetrachords, pentachords, and even hexachords, not to mention trichordal melodies. Also, problems occur when a song contains more than seven scale steps of a diatonic octave-mode (either with smaller intervals or different intervallic structures of scale segments). Twentieth-century researchers understood that diatonic scales did not offer enough opportunities for describing this repertoire. However, for example, musicologist Margarit Brutyan has proposed that in order to describe Armenian traditional music we have to form new scales by combining different diatonic octave-modes (Brutyan 1973: 231-233). Nevertheless, this method seems to make their usage for analysing Armenian traditional music even more disputable.

\section{A COMPARATIVE ANALYSIS OF THE TRANSCRIPTIONS OF THE FOLK TUNE CHEM CHEM}

This song is a dance song and we have three transcriptions of it, all made in Limondjian system. ${ }^{18}$ One version is by Komitas (Fig. 1) and two more are by Brutyan (Figs. 2 and 3). The lyrics are approximately the same in all three versions. The melody of Chem chem consists of two lines, both begin and end with $\mathrm{C}$ (in one transcription Brutyan has presented $\mathrm{C}$ in the first two bar as a lower appoggiatura to D-flat). The final segments of the lines are similar but initial segments contrast: at the beginning of the first line of the melody, a motive is repeated, 'twisting' around the initial $\mathrm{C}$ (the whole scale is (G)-AB-flat-C-D-flat-E-F), ${ }^{19}$ while at the beginning of the second line, the melody ascends from $\mathrm{C}$ to $\mathrm{F}$, bringing in the 'oriental' gap - an augmented second or minor third (D-flat-E) - which is described in terms of the European system of diatonic modes. In the transcriptions this characteristic element of the melody is presented differently: in Komitas's transcription the movement (D-flat-E) 


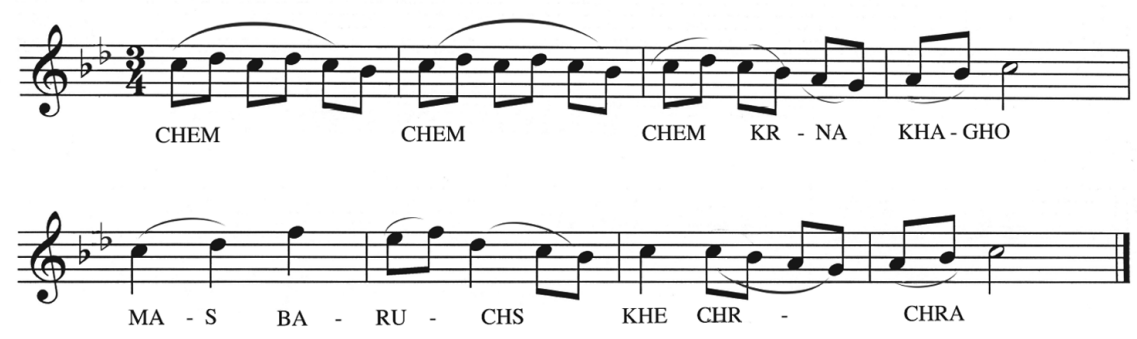

Figure 1. Chem chem by Komitas.

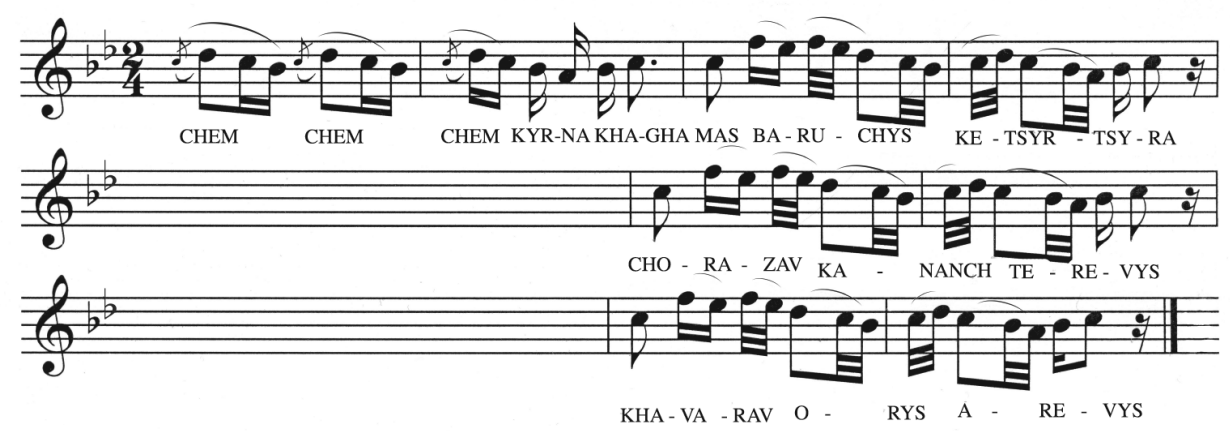

Figure 2. 1st version of Chem chem by Arshak Brutyan.
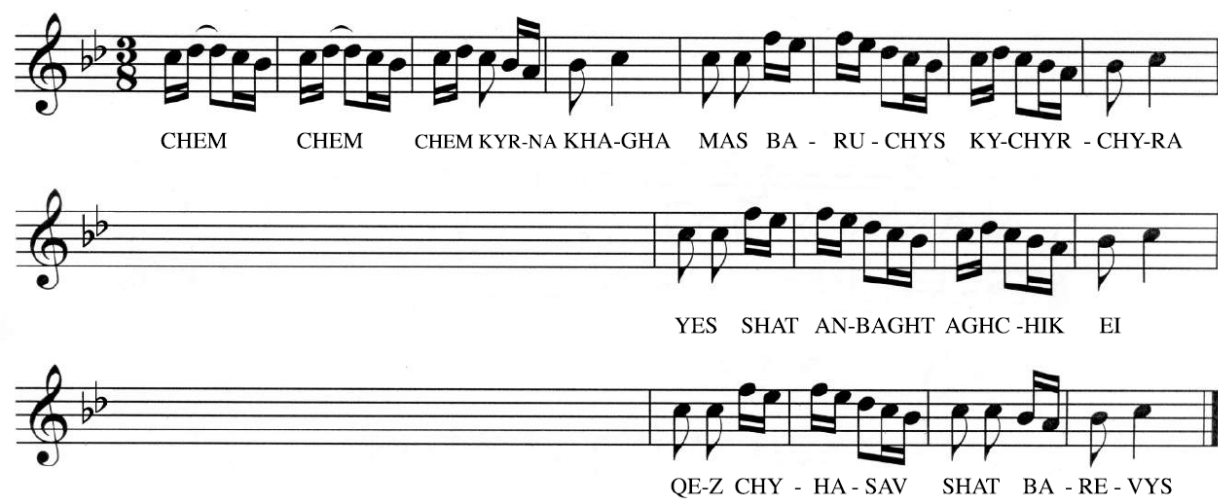

Figure 3. 2nd version of Chem chem by Arshak Brutyan. 
does not occur as a melodic interval between two consequent tones, while in Brutyan's, as we see below, that is much more prominent.

More remarkable differences between the transcriptions occur in the notation of rhythm. Armenian monodic music is melismatic and rhythms are irregular (Pahlevanyan \& Kerovpyan \& Sarkisyan 2001), and in Komitas's transcription this aspect is clearly smoothed, resulting in a rather simple melody in $3 / 4$ time with relatively homogeneous movement. It is difficult to distinguish the embellishing tones from structurally more important ones. In stressed positions - such as the beginning of a bar or a beat, or a long note - the tone $\mathrm{C}$ prevails. Both melody lines contain four bars, just as in the structure of a classical period. As for the tonal structure, balance and completeness are not very strong, but certain developmental characteristics can be found at the beginning of the second melody line containing a rise to the high fourth. Only seconds and thirds are used as melodic intervals, although in the sixth bar this 'oriental' gap is noticeable between structurally important tones, but it does not occur directly in the melody.

Another important difference in Komitas's transcription as compared to Brutyan's is G in the final segment of both melody lines; thereby the melody in his transcription covers almost the whole octave span, confirming the impression that also tonal structure is 'adapted' to the western tradition. In this way, it would be easy to harmonise the melody and transpose it into different tonalities. This, in fact, was done by Komitas in his compilation of solo songs where the song was in G minor (Komitas 1960: 75-76). Of course, while singing or playing only the melody, it is possible to use this transcription as a scheme and perform rhythms as well as pitches more freely, so that a performer knowing the tradition would certainly be able to 'transform' the melody back to Armenian tradition.

Brutyan's transcriptions are rhythmically more diverse. He has transcribed one version of Chem chem in duple and the other in triple time (2/4 and 3/8). In both cases the eighth note is the basic time unit. It is quite common in Armenian folk music for the same melody to be used for dances with different time signature (Atayan 1965: 33-34). Regardless of the time signatures, the way Brutyan has transcribed rhythmic figures does not leave one with the impression of strict metrical thinking. When comparing the two transcriptions by Brutyan, one can easily imagine that it would have been possible to transcribe the two initial syllable figures in the same way: in both cases $\mathrm{C}$ is a short note before a much longer D-flat, followed by quickly descending to B-flat. The same closeness can be observed through the melody. Hence, live performances might not have been so different from the visual notation; rather, they just did not fit very well with the European notation system. At the beginning of the twentieth century 
it was common for musicians-transcribers to consider the time-signature as something that was obligatory in notation, and they tried to convey the rhythms of various different traditions by means of using ever-changing signatures, ties, appoggiaturas, and various additional symbols to fit what they heard into the measures. In Brutyan's first (2/4) transcription, the visual image suggests stronger durational (structural) differentiation between the tones of the melody. Some notes are clearly embellishments to the longer and central tone of the syllable figure. As mentioned previously, Brutyan's transcriptions do not contain descending to $\mathrm{G}$ at the end of both lines, so the melody's pitch range is narrower (A-B-flat-C-D-flat-E-F). The most important difference, however, occurs at the beginning of the second line. In both of Brutyan's transcriptions the 'oriental' gap occurs between consecutive tones (in the descending passage F-E-D-flat). Although E is structurally less important, the characteristic 'oriental' sound becomes more prominent than in the transcription by Komitas. Certainly, all singers performed the song in their own way; however, a comparative analysis leaves the impression that Brutyan tried to record the melismatic character of the melody and its specific intonations while Komitas adapted it more in line with European ideas of a song.

\section{A COMPARATIVE ANALYSIS OF THE SONG LE LE YAMAN}

There are again three transcriptions of this lyrical song, one by Komitas (Fig. 4) and two by Brutyan (Figs. 5 and 6), all made in Limondjian system. ${ }^{20}$ This time, Komitas has dropped the time signature and marked only structural divisions and repetitions with bar lines. The first section contains three melodic phrases that correspond to the structure of the stanza, while the second four and the second section are repeated, and therefore the form of the strophe is ABB. There are also repetitions in the phrases, with the three phrases of the first section containing two melodic motives, $\mathrm{ABB}$, and the four phrases of the second section bring in only one more melodic motive that is repeated like a tonal sequence (ac1c2c3), with the last link ending in the 'tonic' $G$ (we can think in terms of a natural $g$-minor or the dorian mode from $\mathrm{G}$, but the tone E-flat or $\mathrm{E}$ that would define the mode unambiguously is missing and the scale is G-A-B-flatC-D-F). Komitas has chosen longer rhythmic values than Brutyan, and the time signature is absent. This absence might have ideological meaning but in the context of Komitas's transcriptions it probably refers, with longer rhythmic values, to a slow and rhythmically-free performance in which the durations are vague and only long and short notes are clearly differentiated. 


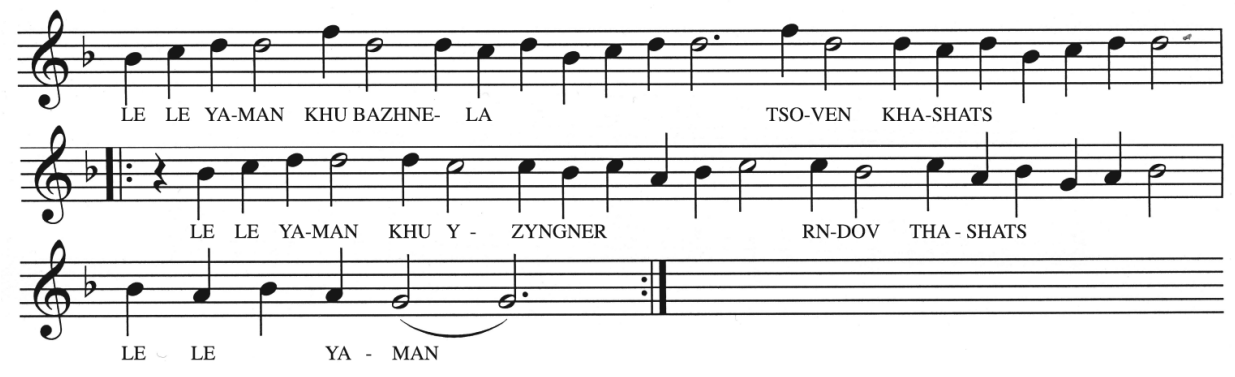

Figure 4. Le le yaman by Komitas.

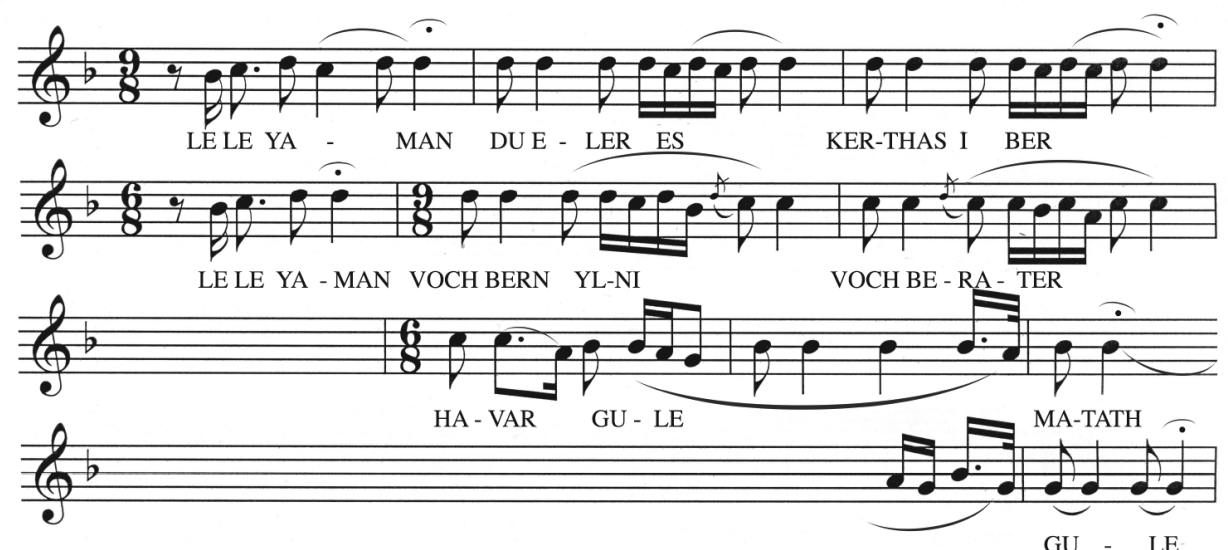

Figure 5. 1st version of Le le yaman by Arshak Brutyan.

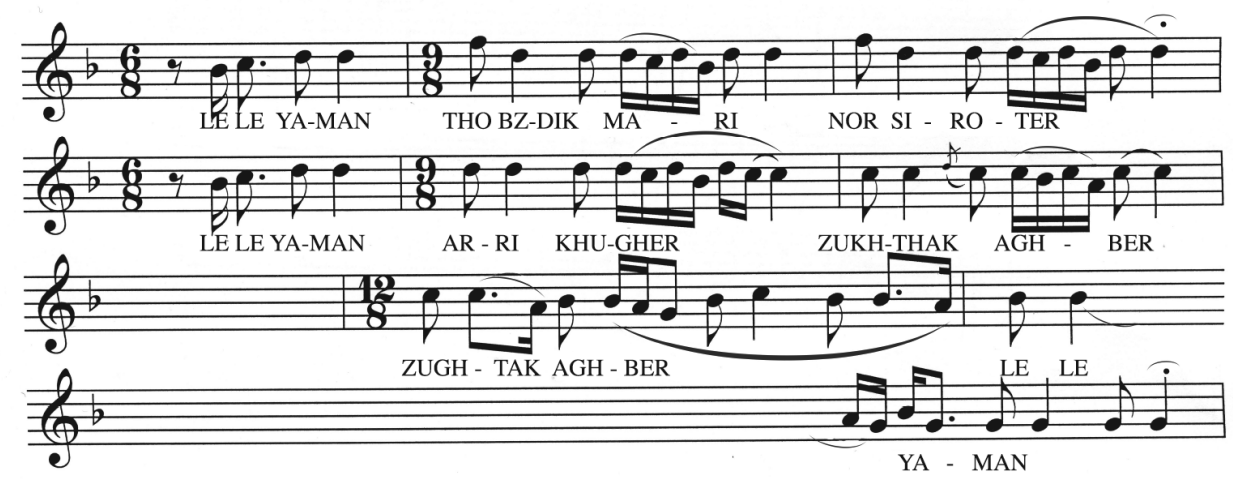

Figure 6. 2nd version of Le le yaman by Arshak Brutyan. 
Brutyan has preferred shorter note values, and has tried to record more nuances. In both transcriptions he has used the sixteenth, eighth, dotted eighth, and quarter notes, fermatas in some phrase endings, and once an appoggiatura and a tie. He has time signatures that constantly change. So his bar lines also mark structural divisions, but in this case using phrases (corresponding to the poetic lines), and not sections of the strophe.

What is more, Brutyan has recorded more small variations and embellishments in the melody and it does not seem so repetitive (schematic) as Komitas's transcription, although structural repetitions are the same. Quite an essential difference between Brutyan's own transcriptions is the lack of F in the first version, with the result that the tonal range of the melody is only fifth (G-A-B-flat-C-D). In Brutyan's second version and in Komitas's transcription, $\mathrm{F}$ occurs in accented positions and is an important characteristic of the song as, due to the lack of E-flat or E, the 'oriental' gap in the scale compares with the European diatonic modes.

\section{CONCLUSION}

The aim of this article was to show how transcriptions of folk tunes can reveal ideas about national identity in a much wider cultural context.

The transcriptions of the songs that have been compared were very similar in many aspects, considering their formal and tonal structure. Evidently, to some extent, both folklorists relied on the same theoretical framework. For example, as was typical of the period, most of their notations were in G (Brutyan 1985: 18) and they used the Limondjian system. At the same time, there were remarkable and systematic differences in the transcriptions of rhythmical figures, metric (or non-metric) structures, and melodic figuration.

In Komitas's transcriptions the rhythmic patterns are simpler. It seems that he used schematised rhythms as if they were a more universal solution. Brutyan, on the other hand, seems to have tried to record the rhythmic thinking inherent in an Eastern culture in the Western notation as accurately as possible. Noteworthy differences can also be noticed concerning Komitas's and Brutyan's melodic thinking. The first, for example, is characterised by adjusting modes, 'masking' the supposed augmented second, etc. Hereby, one has to emphasise that the tendencies described above can also be seen in other transcriptions made by Komitas and Brutyan. While comparing transcriptions by both of them with live music, Brutyan's transcriptions seem more relevant. This way, an impression forms that there are so many differences in transcriptions not 
because the songs were transcribed in different times and places but rather because of the priorities and personal choices made by folklorists.

As was said before, Komitas did not consider ashugh art to be 'real' Armenian music as it was strongly influenced by Middle Eastern art (Shaverdyan 1989: 106-107). The influences of European musical thinking can also be traced in the sound recordings: in 1912, he and his pupil, Spiridon Melikyan, were recorded performing folk tunes that they had collected. When compared to the recordings of traditional musicians, the intonations of Western classical music can clearly be heard. ${ }^{21}$

In contrast to Komitas, Brutyan did not work only with folk tunes, but transcribed much ashugh art music, and today this is considered to be his major contribution to Armenian musicology (Brutyan 1985: 17). Also, his transcriptions of simple folk melodies seem rather complex and often remind one of ashugh art. Unlike Komitas, Brutyan did not travel in the cultural centres of the West, but spent most of his life in Alexandropol, the centre of the ashugh community in the nineteenth century, and the famous ashughs, Jivani and Sheram, often performed at his concerts (ibid.: 15). One can only guess how much those circumstances influenced what he valued in folk music while making the transcriptions.

Today, Komitas's folk tune transcriptions are used as an authoritative source of traditional music. ${ }^{22}$ Indeed, they provide a good source of information for someone who knows the tradition. However, in Armenian traditional music we meet a blending of different cultures as this was a liminal space of various high cultures: Middle Eastern monody, European classical music, and traditional Armenian church singing. For that reason, the transcriptions from the nineteenth century should be approached carefully, as a comparison to recorded and living performances reveals that transcribers have 'corrected' the tunes, adapting them to the Western European system.

\section{NOTES}

1 For example, according to Geodakyan, Komitas foresaw "his mission already in his youth, and moved towards it, obstinately and stubbornly" (S iunosheskikh let on slovno predugadal svoe predznaznachenie i otnyne shel k izbrannoi tseli priamo i uporno) (Geodakyan 1969: 48).

${ }^{2}$ Ashughs - Middle Eastern minstrels who were narrators, singers, instrumentalists, dancers, and actors in one.

3 Komitas: The Complete Works, vol. 9-13 (1999-2004); Etnograficheskii sbornik, Armianskie narodnye pesni $i$ pliaski, tom 2 (Ethnographic collection, Armenian folk 
songs and dances, vol. 2) (1950); Armianskie narodnye pesni, etnograficheskii sbornik (Armenian folk songs, ethnographic collection) (1931).

4 Brutyan, Arshak 1985. Ramkakan Mrmunjner (Peasant Songs). Yerevan: Sovetakan groh.

5 Gevonyan, Armenuhi: Taronizhoghourdakan yergery (Folk songs of Taron region)(1978); Toumajian, Mihran: Armenian Folk Songs 4 (2005); Melikyan, Spiridon: Armianskie narodnye pesni $i$ pliaski 1 (Armenian folk songs and dances 1) (1949), Armianskie narodnye pesni i pliaski 2 (Armenian folk songs and dances 2) (1952); Muradyan, Hayrik: Rodnye pesni (Native songs) (1980); Toumajian, Mihran: Armianskie narodnye pesni 2 (Armenian folk songs 2) (1983), Armianskie narodnye pesni 3 (Armenian folk songs and dances 3) (1986).

${ }^{6}$ Pahlevanyan, Alina: Talin: Zhoghourdakan yergery [Talin: Folk Tunes] (1984). Yerevan: Sovetakan groh.

7 Hayrik Muradyan. Musical Relics of Armenia. CD. Recorded in Armenia from 1958 to 1988. Digitally remastered by ADD. Sondex, 2000.

${ }^{8}$ Live performance by Margarit Voskanyan, four sessions on 12-14 January 2013.

9 For such approaches see, for example, Levon Abrahamyan's Armenia and Armenians between East and West (www.noravank.am/upload/pdf/260_en.pdf, last accessed on October 9,2015$)$. See also the analysis of this topic by political scientist Ronald Grigor Suny, Constructing Primordialism: Old Histories for New Nations (2001).

${ }^{10}$ In the original: "[---] zhiznennyi put' Komitasa otrazhaet ne tol'ko i ne stol'ko ego lichnuiu sud'bu, skol'ko sud'bu vsego armianskogo naroda".

${ }^{11}$ In the original: "V samom sud'be Komitasa, ego zhiznennom puti, ternistom i tragicheskom, otrazilas' tselaia epokha istorii armianskogo naroda. Vremia pod"ema natsional'nogo samosoznaniia, bor'by, rozhdavshikhsia nadezhd i vremia sversheniia uzhasnoi tragedii 1915 goda, zatmivshei samye strashnye stranitsy mnogostradal'noi armianskoi istorii. Komitas do kontsa ispil gor'kuiu chashu stradanii, vypavshikh na doliu ego naroda."

12 See, for example, Geodakyan 1969, Shaverdyan 1989, Pahlevanyan \& Kerovpyan \& Sarkisyan 2001.

13 This, in fact, reflects broader changes: according to Smith, there was a clear division between a Western-orientated, more liberal Armenian nationalism emanating from the diaspora in Istanbul, Vienna, and Paris, and an Eastern-orientated revolutionary nationalism which owed more to Russian populism and German thought (Smith 2010: 12).

${ }^{14}$ For example, Toumajian, Mihran: Armianskie narodnye pesni 4 (Armenian Folk Songs 4) (2005); Melikyan, Spiridon: Armianskie narodnye pesni i pliaski 1 (Armenian folk songs and dances 1) (1949) and Armianskie narodnye pesni i pliaski 2 (Armenian folk songs and dances 2) (1952); Toumajian, Mihran: Armianskie narodnye pesni 2 (Armenian folk songs 2) (1983) and Armianskie narodnye pesni 3 (Armenian folk songs 3) (1986). 
${ }^{15}$ There were some differences in intoning the scale steps vernaghagh ( $e$ in Western notation) and nerknaghagh ( $a$ in Western notation).

${ }^{16}$ See, for example, Geodakyan 1969: pp. 84-85.

${ }^{17}$ See, for example, Brutyan 1973: 226-229; Pahlevanyan 2002: 10.

${ }^{18}$ Transcriptions into the European system were made by the author.

${ }^{19} \mathrm{G}$ occurs only in Komitas's version.

20 Transcriptions into the European system were made by the author.

${ }^{21}$ The Voice of Komitas Vardapet (CD). Recorded in Paris, 1912, digitally remastered by Anima Vox. OCTA Records Co Ltd., 1994.

${ }^{22}$ See, for example, the Grove Dictionary of Music and Musicians.

\section{ARCHIVAL MATERIALS}

House-Museum of Charents in Yerevan: Chem chem Komitas, fund 302, No. 131; Chem chem Brutyan, fund 4, No. 136; Le le jaman Komitas, fund 302, No. 135; Le le jaman Brutyan, fund 3, No. 31 .

\section{REFERENCES}

Adalian, Rouben Paul 2010. Historical Dictionary of Armenia. Lanham, Maryland: Scarecrow Press.

Anderson, Benedict 2006. Imagined Communities. London \& New York: Verso.

Atayan 1965 = Ataian, Robert. Armianskaia narodnaia pesnia. [Armenian Folk Songs.] Moskva: Muzyka.

Atayan 1973 = Ataian, Robert. Armianskaia srednevekovaia notopis'. [Armenian Medieval Notation System.] In: V. Vinogradov (ed.) Muzyka narodov Azii i Afriki. [Music of Asian and African Nations.] Moskva: Sovetskii kompozitor, pp. 168-186.

Bhabha, Homi K. 1994. The Location of Culture. London \& New York: Routledge.

Bohlman, Philip V. 2001 [1999]. Ontologies of Music. In: Nicholas Cook \& Mark Everist (eds.) Rethinking Music. New York: Oxford University Press, pp. 17-34.

Brutyan, Arshak 1985. Ramkakan Mrmunjner. [Peasant Songs.] Erevan: Sovetakan grokh.

Brutyan, Margarit 1973. Ladovaya sistema armyanskoy narodnoy (krest'yanskoy) muzyki. [Modal System of Armenian Traditional (Peasant) Music.] In: I. Zemtsovskiy (ed.) Problemy muzykal'nogo fol'klora narodov SSSR. [Problems of Music Folklore of the Nations of the Soviet Union.] Moskva: Muzyka, pp. 226-238. 
Dahlhaus, Carl 1983 [1980]. Between Romanticism and Modernism: Four Studies in the Music of the Later Nineteenth Century. Berkeley \& Los Angeles: University of California Press.

Davis, Aeron 2008. Investigating Cultural Producers. In: M. Pickering (ed.) Research Methods for Cultural Studies. Edinburgh: Edinburgh University Press, pp. 53-67.

Geodakyan 1969 = Geodakian, Georgii. Komitas. [Komitas.] Erevan: Izd. AN ASSR.

Gevonyan, Armenuhi 1978. Taroni zhohovrdakan yergery. [Folk songs of Taron region.] Erevan: Sovetakan grokh.

Komitas 1931. Narodnye pesni: Etnograficheskii sbornik. [Armenian Folk Songs: Ethnographic Collection.] Erevan: Muz. sektor gos. izdatel'stva SSR Armenii.

Komitas 1950. Etnograficheskii sbornik, t. 2: Armianskie narodnye pesni i pliaski. [Ethnographic Collection, Volume 2: Armenian Folk Songs and Dances.] Erevan: Arm. Gos. izdat.

Komitas 1960. Sobranie sochinenii, T. 1: Sol'nye pesni i duety s soprovozhdeniem fortepiano. [Collected Works, Volume 1: Solo Songs and Duets to the Accompaniment of Piano.] Erevan: Armgosizdat.

Komitas 1999. The Complete Works, Volume Nine: Musical-Etnographic Heritage. Armenian Folk Songs, Book 1. Edited by R. Atayan. Erevan: Gitutyun. Available at http://serials.flib.sci.am/openreader/Hay\%20jox.erg.-1999/book/Binder1.pdf, last accessed on November 19, 2015.

Komitas 2000. The Complete Works, Volume Ten: Musical-Ethnographic Heritage. Armenian Folk Songs, Book 2. Edited by R. Atayan. Erevan: Gitutyun.

Komitas 2000. The Complete Works, Volume Eleven: Musical-Ethnographic Heritage. Armenian Folk Songs, Book 3. Edited by R. Atayan \& G. Gyodakyan. Erevan: Gitutyun.

Komitas 2003. The Complete Works, Volume Twelve: Musical-Ethnographic Heritage. Armenian Folk Songs, Book 4. Ethnographic edition. Edited by R. Atayan \& G. Gyodakyan. Erevan: Gitutyun. Available at http://serials.flib.sci.am/ openreader/Hay\%20jox.\%20erg.-2003/book/Binder1.pdf, last accessed on November 19, 2015.

Komitas 2004. The Complete Works, Volume Thirteen: Musical-Ethnographic Heritage. Armenian Folk Songs. Modal collection, facsimile edition. Edited by R. Atayan \& G. Gyodakyan. Erevan: Gitutyun. Available at http://serials.flib.sci.am/openreader/ Hay\%20jox.\%20erg.-2004/book/Binder1.pdf, last accessed on November 19, 2015.

Kushnaryov 1958 = Kushnarev, Khristofor. Voprosy istorii $i$ teorii armianskoi monodicheskoi muzyki. [Problems of History and Theory of Armenian Monodic Music.] Leningrad: Gosudarstvennoe muzykal'noe izdatel'stvo.

Lippus, Urve 1988. Regiviiside heliread. [The Scales of Runic Melodies.] In: U. Lippus (comp.) Muusikalisi lehekülgi 5. Tallinn: Eesti Raamat, pp. 88-130.

Melikyan 1949 = Melikian, Spiridon. Armianskie narodnye pesni i pliaski 1. [Armenian Folk Songs and Dances 1.] Erevan: Armgiz.

Melikyan 1952 = Melikian, Spiridon. Armianskie narodnye pesni i pliaski 2. [Armenian Folk Songs and Dances 2.] Erevan: Aipetrat.

Muradyan 1980 = Muradian, Airik. Hayreni yergery. [Armenian Songs.] Erevan: Sovetakan grokh. 
Muradyan 1960 = Muradian, Matevos. Armianskoe sovetskoe muzykovedenie (kratkii obzor). [Armenian Soviet Musicology (Short Overview).] In: Robert Ataian \& Margarit Arutyunyan \& Georgi Budaghian (eds.) Muzyka sovetskoi Armenii: sbornik statei. [Music of Soviet Armenia: Collection of Articles.] Moskva: Gosudarstvennoe muzykal'noe izdatel'stvo, pp. 337-353.

Muradyan, Matevos \& Atayan, Robert \& Tatevosyan, Aleksandr 1956. Armianskie kompozitory. [Armenian Composers.] Erevan: Armianskoe gosudarstvennoe izdatel'stvo.

Nercessian, Andy 2000. A Look at the Emergence of the Concept of National Culture in Armenia: The Former Soviet Folk Ensemble. International Review of the Aesthetics and Sociology of Music, Vol. 31, No. 1, pp. 79-94. http://dx.doi.org/10.2307/3108426.

Pahlevanyan 1984 = Pakhlevanian, Alina. Talin: Zhoghovrdakan yergery. [Talin: Folk Tunes.] Erevan: Sovetakan grokh.

Pahlevanyan 2005 = Pakhlevanian, Alina. Voprosy armianskoi muzykal'noi fol'kloristiki . [Problems of Armenian Musical Folklore.] Erevan: Izd-vo EGK.

Panossian, Razmik 2002. The Past as Nation: Three Dimensions of Armenian Identity. Geopolitics, Vol. 7, No. 2, pp. 121-146. http://dx.doi.org/10.1080/714000931.

Pickering, Michael 2008. Experience and the Social World. In: M. Pickering (ed.) Research Methods for Cultural Studies. Edinburgh: Edinburgh University Press, pp. 17-31.

Poladian, Sirvart 1972. Komitas Vardapet and His Contribution to Ethnomusicology. Ethnomusicology, Vol. 16, No. 1, pp. 82-97. http://dx.doi.org/10.2307/850444.

Sachs, Curt 1953. Rhythm and Tempo: A Study in Music History. New York: W.W. Norton \& Company Inc.

Shaverdyan 1989 = Shaverdian, Aleksandr. Komitas. [Komitas.] Moskva: Sovetskii kompozitor.

Smith, Anthony D. 2010. Diasporas and Homelands in History: The Case of the Classic Diasporas. In: Allon Gal \& Athena S. Leoussi \& Anthony D. Smith (eds.) The Call of the Homeland: Diaspora Nationalisms, Past and Present. Leiden \& Boston: Brill, pp. 3-25.

Spencer, Jennifer 2001. Sokal's'ky Petro Petrovych. In: Stanley Sadie \& John Tyrrell (eds.) The New Grove Dictionary of Music and Musicians, 2nd edition. London: Macmillan Publishers Limited, pp. 625-626.

Suny, Ronald Grigor 2001. Constructing Primordialism: Old Histories for New Nations. The Journal of Modern History, Vol. 73, No. 4, pp. 862-896. http://dx.doi. org/10.1086/340148.

Ter-Sarkisyants 2005 = Ter-Sarkisiants, Alla. Istoriia i kul'tura Armianskogo naroda . [History and Culture of Armenian Nation.] Moskva: Vostochnaia literatura RAN.

Tololyan, Khachig 2005. Armenian Diaspora. In: Melvin Ember \& Carol R. Ember \& Ian Skoggard (eds.) Encyclopedia of Diasporas: Immigrant and Refugee Cultures Around the World. Volume I: Overviews and Topics. Berlin: Springer, pp. 35-46. Toumajian, Mihran 1983. Armianskie narodnye pesni 2. [Armenian Folk Songs 2.] Erevan: AN Armianskoi SSR.

Toumajian, Mihran 1986. Armianskie narodnye pesni 3. [Armenian Folk Songs 3.] Erevan: AN Armianskoi SSR.

Toumajian, Mihran 2005. Armianskie narodnye pesni 4. [Armenian Folk Songs 4.] Erevan: AN Armianskoi SSR. 
Turino, Thomas \& Lea, James (eds.) 2004. Identity and the Arts in Diaspora Communities. Warren, Michican: Harmonie Park Press.

Wodak, Ruth \& De Cillia, Rudolf \& Reisigl, Martin \& Liebhart, Karin 1999. The Discursive Construction of National Identity. Edinburgh: Edinburgh University Press.

Yazedjian, Ani 2004. Reconstructing the Armenian: The Genocide as a Cultural Marker in the Reification of Armenian Identity. In: Thomas Turino \& James Lea (ed.) Identity and the Arts in Diaspora Communities. Warren, Michigan: Harmonie Park Press, pp. 39-50.

\section{ONLINE SOURCES}

Ambrazevičius, Rytis 2006. Pseudo-Greek Modes in Traditional Music as Result of Misperception. 9th International Conference on Music Perception and Cognition, pp. 1817-1822. Available at http://www.researchgate.net/publication/228842690_ Pseudo-Greek_modes_in_traditional_music_as_result_of_misperception, last accessed on November 19, 2015.

Pahlevanyan, Alina \& Kerovpyan, Aram \& Sarkisyan, Svetlana 2001. Armenia. The New Grove Dictionary of Music and Musicians. Available at http://www. oxfordmusiconline.com:80/subscriber/article/grove/music/42078, last accessed on October 9, 2015.

Samuelian, Thomas J. \& Hajian, Aram \& Martirossian, Hakob \& Hajian, Tamar 2003. Armenia2020: Diaspora-Homeland Issue Paper prepared by the Arak-29 Foundation (Yerevan). Available at http://citeseerx.ist.psu.edu/viewdoc/downlo ad?doi=10.1.1.468.6733\&rep=rep1\&type=pdf, last accessed on October 9, 2015.

\section{RECORDINGS}

The Voice of Komitas Vardapet (CD) 1994. Recorded in Paris, 1912, digitally remarstered by Anima Vox. OCTA Records Co. Ltd.

Muradyan, Hayrik 2000. Musical Relics of Armenia (CD). Recorded in Armenia, 19581988, digitally remastered by ADD. Sondex. 


\title{
ETHNIC AND CULTURAL ASPECTS IN THE DEVELOPMENT OF KAZAKH THEATRES DURING THE INDEPENDENCE PERIOD: THE PROBLEMS OF HUMAN EXISTENCE
}

\author{
Askhat Mayemirov, Kabyl Khalykov, Bakhyt Nurpeis
}

\begin{abstract}
The article gives a detailed description of folklore motifs that became examples for performances in the Kazakh theatre. The interrelation of myth and reality, used as the nature of time, is represented by an existential communicational human existence in the ethno-cultural discourse. Here the conditions of existence for the heroes of both the reality and myth are the same. The comparison of the heroes' lifestyle with Kazakh folklore gives a new interpretation quality to the director's conception and dramaturgy. The heroes' destinies under the totalitarian era of Stalin, Khrushchev, and Brezhnev are imbued with personification of folklore myths and legends. The examples given in the study are related to the cultural-philosophical paradigms of modernity and the values of current ethno-cultural transformations. Thus, the inclusion of folklore into the theatre becomes an influential art trend, in which art seeks to give a comprehensive and vivid real-life picture of a person who fights for his/her own destiny and justice. The Gabit Musrepov Kazakh Academic Theatre for Children and Youth solves these problems, using the comparative method of folk stories, encouraging the viewer to understand and appreciate the philosophical meaning of human life and existence. The study uses the ratio of diachronic and synchronic presentation of texts and artefacts as regards current events from the perspective of folklore studies, theatre studies, and art history, as well as from the cultural-philosophical viewpoint.
\end{abstract}

Keywords: acting, dramaturgy, folklore, folk wisdom, performance, philosophical sense

\section{THE VALUABLE MEANING OF THE CULTURAL- PHILOSOPHICAL PARADIGM OF MODERN ART}

Art offers an ideal opportunity to explore the constantly mutually forming human-world system in the form of a regulated model that really exists. Art is a mirror in which a person sees him/herself as reflected in the environment, to say more exactly, sees his/her image in the worldview. The authors suggest understanding the worldview in the most general terms, as an orderly knowledge 
of the reality formed in the public (as well as group or individual) consciousness. Both the image and the picture in the model can randomly change themselves, accepting any forms accessible for imagination. The man-made mirror reflects not only conscious efforts of the creator, but also people's intents, emotional state, and undeveloped properties, and their environment concealed from them. Through the spectator, who perceives a work of art, a feedback is 'locked' in a sense, which allows for classifying and evaluating both the effectiveness of the expressive methods and the peculiarities. It is impossible to find another area of human activity, in which the objective and subjective, reality and fantasy, natural and artificial, conscious and unconscious, mind and senses could be combined to such extent.

The years of independence and sovereignty of the Republic of Kazakhstan have undoubtedly been marked by successes in all spheres, including folklore and theatre. A closer look at the past with a view to learn lessons for the future is a specific feature of the social sciences of today. Therefore, there is a permanent interest in folk culture. The present time is, on the one hand, characterised by urbanisation motifs, and on the other - by the idea of continuity through a new vision of images and means of folklore expression, as well as ways of its rethinking in the context of new aesthetic views.

The specific role of folklore and music in the life of the Kazakhs is reflected in many ancient myths and legends, which confirms the deep historical roots of this cultural layer. Quite a few pieces of art could be compared with the depth and beauty of these myths and legends in Kazakh folklore. They were created by ancient tribes and peoples who promoted the ethnogeny of the Kazakhs, who, in turn, developed rich cultural traditions of their ancestors. Attempts to develop these myths, folklore legends, and deep philosophical understanding of the people often became food for thought as regards Kazakh stage directors, writers, playwrights, and artists. Creative intellectuals, despite certain conflicts arising between the classical tradition and innovation, perceive the deep transformation of art. This results in a completely new dimension of human existence. In this regard, Martin Heidegger properly comments: "Art is put forward in the aesthetics horizon. This means that the literary work becomes the subject of emotional experience, and, accordingly, art is considered to be the expression of human life" (Heidegger 1997: 438). The status of art presupposes non-classical structure of the literary world and equal co-existence and communication of different cultural worlds, linked to the life activity of similarly different, particularly dynamic changeable human beings, who organise themselves according to political, management-economic, ethnic, religious-ethnic, and value-based principles. 
The communicative principle of the literary (cultural) world structuring, which by the end of the century became predominant, changes the way and form of art existence, which becomes a largely significant formation (discourse), bearing (transmitting, communicating) valuable meanings. (Khalykov \& Begalinova 2013: 136)

\section{CREATIVE CONCEPTS OF THE KAZAKH THEATRE DURING THE YEARS OF INDEPENDENCE (1991-2015)}

Kazakh folklore, deeply rooted in antiquity and ethnic history, is represented by heroic tales, lyrical and epic poems, tales, and legends, created mainly on the basis of historical events witnessed by people. Their primary sources could be short stories about the heroism of people, distinguished by military prowess, stories about the tragic love of unhappy young people who challenged injustice, active and proactive people's imagination that revealed itself in the struggle against natural forces. They are deeply patriotic by content, poetic in presentation, imbued with a call for unity, fortitude, perseverance, and tenacity in pursuit of the goal. These stories like a drop of water reflect the fate of these people, their wisdom, and attitude toward the world. Kazakh folklore is unique; it includes more than forty genre varieties, many of which are typical only for Kazakh folklore. This folklore is inexhaustible: it includes not only heroic legends, lyrical and epic poems, stories, legends, folk songs, love and ritual songs, philosophical reflections, dedications, and instructive tales, but also many witty sayings, riddles, aphorisms, proverbs, farewell and funeral chants, lullabies, incantations, and spells, giving a complete picture of the Kazakhs' existence and world outlook.

For many foreign countries, our literature and art are among the main sources of information about the past and present life of the Kazakh people. The intelligentsia of the Asian and African colonial countries, keeping in mind our example, is starting to realise that cultural development depends on political and social freedom, which opens up opportunities for the spiritual growth of the people. (Satpaeva 2015)

The Gabit Musrepov Kazakh Academic Theatre for Children and Youth, more commonly known as the Theatre for the Young Spectator (TYS), has greatly contributed to the development and formation of literary and spiritual culture of our country, the aesthetic taste and world outlook of the young generation, and played a certain role in the development of Kazakh theatrical art. 
Under new historical conditions of the twenty-first century, given the globalisation of all life realities, sharp transition from one social formation to another, and social stratification into rich and poor, the problems of the preservation of the Kazakh nation as an ethnic group complete its mentality, language, and also physical nature. The generally Turkic achievements have become a significant spiritual basis in search of prospects: big worldwide archaeological excavations near Aktobe, in Altai, the decoding of ancient and medieval texts from China, the Far East, the CIS (the Commonwealth of Independent States - the former Soviet republics) countries, and inscriptions on Kultegin stele (a stone statue of the ancient Turkic period). Moreover, the appearance of works authored by Lev Gumilev, Murat Adji, Chingiz Aitmatov, Mukhtar Shakhanov, Olzhas Suleimenov, and the CIS and West orientalists have contributed to a great extent as well.

One could also mention the studies of several prominent researchers of Kazakh folklore. For example, the study titled From Folklore to the Epic Novel by Sheriazdan Eleukenov is a fundamental research that reveals patterns of origin, formation, and development of the Kazakh novel from its beginnings to the works of contemporary writers, which meet high professional standards of novelistic art. The author has studied a solid amount of materials related to the artistic heritage of the Kazakh novel (Eleukenov 1987).

Also, the studies titled The Folklore of Kazakh People in the Contemporary Art of Pavlodar Region (2008) and The Folkloric-Mythological Heritage of the Kazakh People (2007) by Daniyar Mergaliev discuss one of the most topical and popular themes of today's music studies - folk music and music folklore, the history and culture of the Kazakh folk art.

The monograph of Sanya Kabdieva on the folk traditions in the Kazakh theatre discusses the development of folk traditions in the modern Kazakh theatre and identifies the interaction patterns of folklore and artistic structure. The author has studied the influence of these traditions by specific examples of theatrical practice (Kabdieva 1986: 112).

Rich content and various forms of folklore as well as its new productive development testify to the fact that the ancient poetic culture offers opportunities for taking a closer look at the life of the Kazakh people, to feel kinship with their thoughts and interests. It is the word of art that opens up new horizons of human life and culture.

Modern Kazakh philosophy believes that "[---] the mankind understood the necessity of cultural diversity and importance of keeping the idiosyncrasy of ethnic cultures as a factor of human civilization existence" (Aiupov 2006: 74). All this in general corrects the Turkic views on the past, present, and future. 


\section{TIME TO ESTIMATE:}

\section{IN SEARCH OF UNIVERSAL MORAL VALUES}

Kazakh academic drama theatres, like all the theatres in Kazakhstan and the CIS, are trying to find answers to questions such as how to respond to the negative challenges of time and to preserve the eternal moral values of the mankind, and how to oppose evil in all its forms. The TYS aspires to find and disclose people with high ethical principles and multi-sided personal qualities as well as rich spiritual values, this way indicating the right direction of today's life studies, showing real conflicts, characters, and types of interrelations. In this regard, the theatre approaches contradictory psychological aspects and life collisions. The theatre reveals images of modern business people as well as those who are presently called 'the lost generation'. This is a huge number of people of all ages and different social strata. They feel psychologically wretched due to all the negative consequences of the sharp and quick stratification into rich and poor. This is a widespread problem for all the CIS peoples.

During all these years, the TYS has turned to the works of different authors and used all the genre varieties, experiencing both visible success and, naturally, also certain loss in this process. Changes in stage managers' and actors' generations are taking place continuously.

\section{THEATRE AGAINST TOTALITARIANISM}

The issue of disclosing grave facts of Soviet totalitarianism was among the first TYS creative searches and became a topical one during the period 1932-1960. First, there was the 'test site' theme. A drama by Olzhas Suleimenov and Bakkoja Mukaev, titled Zamanakyr (The End of the World, 1992), revealed a nation-wide tragedy: moral and physical sufferings and ecological catastrophes. Stage director Raimbek Seitmetov used publicistical means to display physical abnormalities, psychological depressions, etc. He also emphasised the scornful attitude of the Soviet power towards people's troubles. This performance appeared after closing down the Semipalatinsk test site. Along with the mass media, the theatre was the first to highlight in full scale the facts of national grief on the first anniversary of the sovereign state. The performance in which Gulzhamal Kazakhbaeva was playing appealed to the moral and social-philosophical heights. During all the years of atomic explosions her hero, Salikha, one after another buried her children, husband, neighbours, and relatives. Having survived several tragedies in succession, she nevertheless remained humane and firm. 
This performance is built up on the contrast of two acts. In the first act, the spectator becomes witness of a wedding and high hope for the happiness of Dastan and Malika. However, the festive atmosphere is spoiled by horrible reality: both the white-bearded aqsaqals (male elders) and youths frequently reach for a bottle of alcohol. The stage director's intention is to emphasise the fact that during those years such a social evil as alcoholism entered into the lives of the Kazakh nation. Officer Toleubaev comes on behalf of the local garrison and passes a command for all to evacuate immediately as tests are going to be conducted. Nevertheless, the agitated crowd is not going to leave the native places. Having survived almost a century-long suffering in their fight against Kalmyks for independence, as well as some other grave events, such as wars, people expect to survive the unknown evil. This is a historical-genetic stereotype of national behaviour. However, the reality of atomic explosions dissolves their determination. In the second act, the heroes and their tragic destinies appear in full: all Malika and Dastan's seven children die after birth, and the eighth child is born without hands and legs. In the end, the audience learns that Malika has gone crazy because of her grief, and Dastan has hanged himself. Salikha's twelve-year-old son suddenly becomes blind. The aul practically dies out. The remaining seven-eight people become incurably ill. In the final scene Salikha is sitting alone against the background of the dead aul in a huge steppe; however, judging by her pose, the spectator can see a sparkle of hope for revival. The TYS shocked the spectator by displaying these fearful phenomena through the images of characters, their expectations, confessions, and calls for help.

This performance contributed to the development of national self-consciousness: the socially active people fostered the appearance and strengthening of the Nevada-Semipalatinsk international antinuclear movement.

\section{THE THEME OF STALIN'S REPRESSIONS}

"Those who go against the tide can't deserve the people's pride," is one of the famous sayings from the folklore of the Kazakh people. The exposure of mass betrayals of people during the years of Stalin's repressions became another innovative theme at the TYS and the Kazakh theatre in general.

In 2004 playwright Akim Tarazi wrote a play titled Indet (The Epidemic) in the tragicomedy genre. Stage director Esmuhan Obaev staged a play in which the protagonist turned traitorous, constantly writing letters of denunciation not only against the aul's inhabitants, but even against his own father, mother, wife, and daughter. Actor Doskhan Zholzhaksynov was extremely skilful in 
exposing the phenomenon of Azbergen's (the protagonist) betrayal in terms of both psychology and satire. He justified himself in his internal monologues, blaming the time. The actor immediately changed himself internally in the images of Lenin, Stalin, and Brezhnev. He used the specific intonation of these characters, as well as gestures and mimic peculiarities typical of them. The actor recited his monologues, looking directly into the audience, suddenly switching over to the realistic manner of his hero's behaviour. These immediate changes were very convincing. The protagonist's religion was the will of Bolsheviks and the party. Stalin called such blind executors of the party's directions swordbearers - people devoid of humaneness, honesty, and decency.

In the play, Azbergen feels himself to be the most reliable screw in the state's repressive machinery. The emphasis is always laid on such key figures, as under any circumstances the authorities could rely namely on them. So, the finale can be perceived symbolically: Azbergen, who is tenderly touching the loops of gallows, is very sad about the former times. He was a blind screw in terrible machinery and did not understand his fault and the sin of betrayal. Azbergen's victims exerted pressure on his psyche in his visions. The ghosts of dead people constantly appeared before him, and the phantoms of his mother and wife angrily blamed him. However, none of the external factors or his visions could change his outlook. With the collapse of the USSR new times began. The only thing left for his former chief was to wait and hope until they were able to return to the old 'deeds' and habits. The author warns the spectator about the danger deriving from such people, calling for watchfulness. All the actors (mother - K. Kazhygalieva, father - S. Rakyshev, wife - G. Kazakhbaeva, daughter - K. Baitleuova) played emotionally and truthfully, exposing different levels of national sufferings.

\section{THE DESTINY OF YOUTH IN MARKET CONDITIONS}

The themes of modern TYS performances are different. They include destiny of the young people, who have lost contact with their roots and traditions and found themselves in the atmosphere of the market economy machinery, rejecting moral and religious foundations, their old parents and new-born children. Soullessness, cruelty along with alcoholism, drug addiction and prostitution have become widespread vices.

During that period the following performances were in the repertoire: Auyldan kelgen aru (The Girl from Aul, 1992) by I. Saparbai, En ademi kelinshek (The Most Beautiful Woman, 1993, staged by S. Balgabaev), Zhetim burysh (Orphan's Corner, 1992, staged by A. Kenzhekov) by S. Murtaza, Myn ishinde 
zhalgyzdar (Lonely among People, 2000) by B. Rimova, Atau-kere (Deathly Bowl, 2003) by O. Bokeev, Alma bagy (Apple Orchard, 2006) by T. Temenov, and others. In the performance The Girl from Aul, the heroine comes to a big city looking for a better life and gets into all kinds of troubles. The play by O. Kenebaev is realistic by nature, descriptions of characters, and conflicts. Modern music, slang, costumes, and other attributes are widely used. Actress Kuljamila Belzhanova creates a truthful image of an aul girl in a big city: with all her naivety, social immaturity, and depression. In the final act she stealthily leaves her child with other people and runs away in desperation - a deed typical of the present time. The TYS demonstrates a new interpretation of the Kazakh girl's image: a forced refusal from the national spiritual values, along with the beginnings of moral degradation.

A play by Raimbek Seitmetov, The Most Beautiful Woman, is just the opposite by nature. The heroine (Gulbarshyn) is a charming, beautiful, and strong woman, who in spite of her negative life experience (her husband is unemployed and a drunkard) remains optimistic and is ready to help others. This woman, whose role is played by L. Kadenova or A. Mambetova, has become one of the favourite characters of the audience. The performance has become a hit and is still in the theatre's repertoire.

The play Lonely among People (stage director B. Atabaev) shows the moral degradation of the youth. Aldan (R. Omarov) and his wife Samal (S. Kabysheva) are unemployed. Aldan's mother Kunzipa (G. Kazakbaeva) shares a room with them. Young people scorn her; they are not interested in the state of her health and her spiritual demands. Having an excellent knowledge of all the traditions and moral values of the Kazakh family, the married couple cynically rejects them: they send the mother into an old people's home. Kunzipa understands the difficult position of her son and daughter-in-law and sympathises with them; so she leaves the house without complaints, heavyheartedly understanding the cruelty of time and society. The theatre shows the process of the loss of human values by the nation.

The greatest social evil - alcoholism - is revealed in the play titled Deathly Bowl (written by O. Bokeev, staged by Mukhamedia Akhmet-Tore). The stage director and leading actor Nurkanat Zhakypbai raises the performance to the heights of physiological and philosophical generalisations. The spectator gets acquainted with him when the protagonist Tagan, a former university teacher and drunkard, is hired as an unskilled worker by his former classmate Eric. The action takes place in a mountainous taiga home (Katonkaragay area in eastern Kazakhstan, not far from Siberia). Tagan's responsibilities include taking care of the cattle, mowing hay, and cleaning the house for a bottle of vodka, food, and a place to live in. N. Zhakypbai realistically demonstrates the 
unattractive appearance and behaviour of his hero. Through Tagan's destiny he traces all the stages of a person's moral and physical degradation: the loss of spiritual values, family, and service career.

Already Tagan's first contact with Eric's mother Nurke becomes an impetus for his spiritual turning point. While drinking tea, the woman tells him in a motherly manner:

Son, you must give up drinking. You must remember that you belong to a good family. Your parents are worthy people. In the time of Stalin's repressions they saved many people, including myself. Son, I will help you myself. I will treat you with herbs. (Nurpeis 2010)

At first Tagan does not pay attention to her words. However, some time later, he begins to follow her advice and accepts her treatment. Then something significant happens: he sees the beauty of Aina, Eric's wife. The hero's life gradually and slowly changes in a positive way. He is less attracted to alcohol, and interest in life and surrounding people awakens in him. Having noticed Tagan's transformations, Eric intentionally makes him return to alcohol. Awakening after a hard drinking bout, Tagan understands his new degradation. He feels pangs of conscience because Nurke's and Aina's care has turned out to be useless and he has not justified their efforts. He is unable to endure such thoughts and feelings, and tries to commit suicide. However, Aina, who happens to be nearby, pulls him out of the loop. Regaining consciousness, Tagan bursts out with emotions and at the end of the monologue he suddenly feels a flow of new energy, and is glad that he is still alive. This scene marks the beginning of Tagan's spiritual healing. The price of his life and death becomes understandable to him and he is happy to be alive, looking forward to his new full-blooded life. This moment becomes a turning point. He gives Aina a bunch of flowers, taken from his bosom. He presents the flowers silently, and she silently accepts them. The spectator understands that they have made a declaration of love. Actor N. Zhakypbai truly and precisely shows all the nuances and emotions in the hero's behaviour. His eyes are incredibly expressive, and there are sometimes confident, sometimes shy gestures, pauses, and the dynamics of acting. The actor reproduces the difficult and delicate process of spiritual renaissance, self-consciousness, dignity, and common sense.

On his way he meets an old hunter, who tells him about his father. The hunter says that his father was an akyn (Kazakh folk poet and singer), and reads one of his verses by heart. Tagan is shocked, and he tries to remember the verse. This meeting gradually changes him and strengthens all his good intentions, awakening in him the love for his motherland, its people, and traditions. The restoration of genetic memory gives a new purpose to his life, creating a desire to find his own self and confirm himself as a member of society. 
Another central character is Nurke, played by R. Ashirbekova, People's Artist of the Republic of Kazakhstan. In many aspects she reminds us of mothers on the Kazakh scenes, and in this aspect she is traditional, with her rich spiritual world, warm-heartedness, and activeness. However, she is also different. In the first minutes, the performance shows a figure of a woman in snow-white clothes, sitting on a white bed and praying, with a rosary in her hands, and it is obvious that she has been hopelessly ill for a long time already. However, she is not depressed. Nurke most actively participates in the destiny of each character and comments on everything that is happening. She appropriately remembers moments from the past life, and permanently evaluates events taking place in the republic, from an average person's perspective.

Being bedridden, the mother turns out to be a positive and energetic engine of the performance: she helps Tagan to change, helps her beloved daughter-inlaw with tender looks and words, encouraging her independence, views, and devotion to traditions. She has a vivid perception of reality and an inner moral reaction to everything that happens. Through her, people express their opinions about alcoholism as a terrible trouble for each family and for the nation as a whole. She represents not only the mother of her son, but also the mother of the Kazakh nation, which desperately fights to preserve kindness and generosity. Nurke is truly religious, yet not a fanatic. The audience understands that her prayers are concerned with not only her personal destiny, but with the destinies of the surrounding people and the whole nation. Actually, Nurke is a Russian woman called Nyura. She has married a Kazakh and given birth to her son Eric, and she has lived in an aul all her life. The meaning of her life is devotion to her family and national traditions. This woman not only learns the Kazakh traditions and customs with full spiritual readiness and desire, but also observes them throughout her life and teaches others. Nurke knows that she cannot call her parents-in-law by name, as this is regarded as disrespect for them, and she has also learnt that it is necessary to give kumis or some other milk drink even to a casual guest after welcoming, as well as to give this guest an honourable place to sit. Also, she constantly remembers that each person must know their family tree up to seven generations and that the Word and Speech have magical meanings: a good word attracts good deeds, and an evil one - evil deeds. She permanently recites fragments from Kazakh epic literature, proverbs, and sayings by heart, and knows the verses of Kazakh poets. Nurke appears as a vivid encyclopaedia of the national worldview and traditions.

The final scene is most comprehensive as regards its content and expressiveness. During the final minutes of her life she drinks several sips of water. (This is the last deathly bowl that in the Kazakh language is called atau-kere, and, as a rule, all people ask for it before death.) Then she reads Koran prayers 
necessary at that moment, and counts rosary beads. Suddenly an unexpected turn follows: Nurke-Nyura recites the formula, "In the name of the Father, and of the Son, and of the Holy Spirit", and reads this Orthodox Christian prayer to the end, and then she crosses herself, lies calmly down, and dies.

This is a big shock both for Aina and for the audience. During the decade they have lived together, she never heard any Russian words from her beloved mother-in-law. So she is deeply surprised. However, already by the end of the prayer, the audience perceives a deep unexplained feeling, which lives in the soul of each person: the belief in one god for all, to whom the humans always turn with prayers in all languages. In her last breath, Nurke-Nyura appeals to Him not only as to a Muslim, but also as to a Christian, as someone with the same beliefs as her parents. Two forms of religion live in concord in her soul, and she makes the audience understand this unity. The theatre here approves of the necessity of religions (as the centre of God) and moral values, which should again become the basis of life.

The modern Kazakh philosophy says:

As regards the continuation of ethnic and cultural self-identification, we can speak about religious identification, proceeding from the assumption of religious diversity as a display of single religiousness. At the same time, this is the normal life of the human community as well. (Aiupov 2006: 101)

Kazakh folklore has kept many traditions emanating from the Tengri beliefs of Turkic peoples. Tengrianism was the prevailing religion before the adoption of Islam, which is marked by the philosopher Nurmagambet Aiupov in the following way:

Tengrianism as a cultural phenomenon, as an open world outlook and as a religious idea is the legacy of our ancestors [---] The disclosure of its manifestations in the consciousness of modern man - the carrier of the ancient Turkic world archetype, allows for making a conscious cultural selection in the variety of modern philosophical ideas. (Aiupov 2012: 5)

Verbal folklore of the Kazakh people, besides other epic forms, has been thoroughly studied by the outstanding Kazakh writer Mukhtar Auezov. He has described the zhoktau from the Kazakh folklore in small and diverse poetic forms. "Every event in the life of Kazakhs - be it birth, death, or marriage - is reflected in a song. Zhoktau is a memorial song, which lists the advantages of the dead person" (Auezov 2012: 3).

Having closed the eyes of the deceased, Aina begins to sing zhoktau, the Kazakh mournful song. This detail once again emphasises the deep idea that morally and spiritually people do not oppose each other as representatives of 
different nations and religions. A. Imanbaeva plays Aina's part authentically, sincerely, and with rich psychological nuances.

The image of another character - old hunter (K. Zhakibai) - is psychologically close to Nurke's image. Although he appears on the stage only twice, in short episodes, he is remembered by the audience as a truly national character, who is a keeper of national memory, spiritual richness, and human tenderness. K. Zhakibai depicts him as a person who remains fair and stable despite all life troubles and who distinctly distinguishes the boundary between good and evil. This is a man of great personal dignity. He helps Tagan in the process of his healing. The old man forms a harmonious spiritual duet with Nurke.

Eric-Nurke's son - is an antipode to all the other characters. He is a strong, well-educated man, who is not satisfied with living merely on salary, without any career prospects. Having left his parents' house, he has built a new one in the mountains and become a social recluse. The main purpose of his life is increasing his wealth. Played by actor K. Kuandykov, Eric is a merciless miser who blazes with fury. He tries to mislead Tagan in order to make him an obedient slave. Beekeeping has made him enormously rich. Eric's insatiability can be blamed on his own mother, which the audience can see in her eyes, the expression of her face, silence, and short annoying remarks.

The stage director N. Zhakypbai uses the method of phantasmagoria. During the whole performance, from time to time the audience can hear the humming of bee swarms either loud nearby or in the distance. Obviously, these are Eric's pets - the basis of his richness. From his remarks the audience learns that his bees are unusual: the local bees are crossbred with the American ones. This new genotype gives more honey, but the bees are very aggressive. The sting of even one of those bees can kill a man. At the end of the performance this happens: one of the bees stings Eric's mother, who dies on the same day.

Bees are Eric's big love. He is enthused when speaking about them, and vividly imitates their movement. At this moment he seems to transform into a bee himself. It is surprising and awful at the same time. Actor K. Kuandykov is psychologically truthful in his monologue and his supple imitation of bee movement has an almost hypnotic impact on the audience. The stage director together with the playwright Oralkhan Bokeev reaches the existential level of thinking: a man who voluntarily rejects moral values reaches the existential level of a fauna species. It is expedient to emphasise here that O. Bokeev wrote his play Deathly Bowl in the mid-1980s. The writer skilfully predicted the spiritual-ethnic collapse, which was interpreted by the TYS in the light of new historical reality. As it turned out, the prophecies made by O. Bokeev came true. Similarly to Zamza's transformation into a cockroach in Kafka's Metamorphosis, the author predicts the destiny of his nation, who feels the colonial oppression, 
war, hunger, genocide, and nuclear tests, and is worried about how the Kazakh nation will be able to keep its mental and physical health and idiosyncrasy.

In the play Deathly Bowl alcohol is considered the poison for the nation, which can destroy the whole ethnic group. The theatre has convincingly implemented this idea with modern underlying themes and details. As a rule, plays devoted to historical themes have been of great importance in the theatre's repertoire. The stage directors and actors subscribe to the spirit of modernity, making spectators their like-minded persons. The historical facts and characters do not remain illustrations of the past; they are filled with a modern spirit. The TYS solves the tasks of cultivating patriotism and responsibility in the youth.

In the play Abaidyn zhastyk shagy (Abai's Youth) (stage director N. Zhakypbai, 1995), the process of Abai's (a Kazakh poet and educator) development as a poet is most substantial. The impulsiveness of his nature, brightness, and power of his internal world, openness and activity of the hero are depicted by $R$. Omarov with great skill. The main innovation of this performance is connected with the original interpretation of Kunanbai's (Abai's father) image. This is a true historical personality. Earlier on, in the performances of the Auezov theatre, Kunanbai was interpreted as a despotic feudal lord and as a negative personality; however, the TYS gives the spectators real facts of his biography and his spiritual world, and shows him as a progressive figure of the nineteenth century, a thinker and a practitioner. The solution of mass scenes, expressing constant unanimity of Kunanbai and Abai with the nation, is very interesting.

The production of Isatai - Makhambet (Isatai - Makhambet, 2003), a play by I. Zhansugurov, staged by Zh. Khadzhiev, demonstrates Isatai's heroism, love to native land and humanity as a batyr (Kazakh hero, warrior) and poet, brother-in-arms of the great Makhambet Otemisuly (the great Kazakh hero, poet, and political figure) in the fight with colonisers in the nineteenth century. Actor T. Meiramov shows with great psychological skill the last hours of Isatai's life. He knows that the armed forces of Zhangir-khan, jointly with the Russian forces, will soon kill him and Makhambet; nevertheless, not wishing to shed the blood of his people, Isatai wants to solve everything in a peaceful way. He believes in the false promise of Zhangir-khan, gets into a trap and dies, defending his land and people. The courage and powerful spirit of the batyr win the spectators' hearts.

The stage production of S. Zhunusov's Turumtaydai ul edy (Falcon's Son, 2004 ) is similar to the former play. Stage director Zh. Khadzhiev reveals the image of the young Abylai-khan in all the components of the play. Teenager Abylai has remarkable character features, such as love for his native land, 
courage, ability to use weapons, and a gift to understand people from different social strata.

It should be specifically noted that the national and classical works remain in the centre of the TYS's activities. A musical drama by G. Musrepov, Kyz Zhibek (Kyz-Zhibek - a Kazakh version of Romeo and Juliet, 1999) - one of the best works of Zh. Khadzhiev, an outstanding stage manager - has been on already for several years. The well-known legend is thoroughly comprehended in deep contextual, psychological, and socio-philosophical aspects. The stage director develops the best achievements of the Kazakh theatre at a high creative level and along with it opens the new artistic structure of the performance in the national classics.

First of all, the performance is filled with deeply personal, philosophical, and psychological understanding of the national heritage to which Kyz-Zhibek belongs. In this regard it should be stressed that the staging methodology is truly innovative, modern, and authentically national. Owing to the creativity of Zhanat Khadzhiev, the Kazakh stage management as a whole was raised on a new level of achievement in classical stage productions. The talented stage director always raises many moral and psychological problems and reveals new problematic issues. In his interpretations, Zh. Khadzhiev effectively uses such categories as time and space, which requires deep understanding of the actors and the spectators. His performances are usually full of powerful psychological and psychophysical energy. All the components of performances are filled with his willpower, which makes visible not only the characters' emotions, but also their secret thoughts and views.

Zh. Khadzhiev always relies on a spiritual-religious basis, national original and philosophical mind-set, and poetic perception of the world. During historicalsocial cataclysms they remained half-forgotten, as if they were levelled. "Due to his powerful creative impetus, the stage director activates this deep knowledge and memory of soul and heart, which come from the depth of time and space, nomad civilization, and live in each spectator" (Nurpeis 2010).

All Zh. Khadzhiev's stage management solutions are always spectacular, informal-extensional, and easily remembered. He is specifically known by using music, painting, pantomime, and metaphors. It should be especially emphasised that he uses metaphors from different sources, such as folklore, natural world, and nomad craft, and also creates new ones. However, using even widely known national metaphors, he puts his emotional, psychological, and philosophical soul in them. Constant creative tension is typical of each of his performances. It is his way of modern historical reality perception and active influence on it. 


\section{KORKYT'S IDEA OF FIGHTING DEATH}

The history of national culture is a process with its own specific features, which are displayed in the events and phenomena, reflecting worldview, world perception, and mental properties of the nation. "The whole Kazakh culture is filled with ideas, images, and symbols, which, to some extent, are connected with the rites, playing, and ethnic groups" (Khalykov \& Karzhaubaeva 2013: 217).

Several stage productions based on the works of Chingiz Aitmatov have been staged at the TYS: Istykkol tragediyasy (Issyk-Kul Tragedy) and Ak keme (White Steamboat) in 2001, by stage director S. Asylkhanuly, Zhan azaby (Soul Sufferings) on the motives of several works by Aitmatov, in 1997 (stage director N. Zhakypbai), and also Korkyttyn kori (Korkyt's Grave) by Iran-Gaip in 2002, which all reveal modern physiological collisions.

The poetic drama by Iran-Gaip, titled Korkyt's Grave (stage director Z. Khadzhiev), has been on at the TYS already during several seasons. In this performance, Korkyt's personality (who, according to folk legends, was a great shaman who fought until death and did not give up) is sacredly meaningful for Turkic peoples and has an interesting dramaturgical and scenic interpretation. The performance does not aim at the reproduction of historical reality of the seventh century; it is rather a reflection of the artistic perception of the present life of people with all the collisions: interpersonal, social, and daily ones, as well as a search for human spiritual values. In this play Korkyt is not displayed as a traditional folk character. The legend about Korkyt, the founding father of Kazakh music, has a deep philosophical content. Korkyt cannot reconcile himself to the inevitability of death and leaves people, going to the eternal nature, but the mountains, steppes, and forests tell him that the destruction has been inevitable. Then Korkyt takes a piece of wood, hollows out a shirgay - the first kobyz (a traditional Kazakh string instrument), and plays the first melody, finding immortality in the art.

Korkyt, impersonated by Baltabay Seitmamytov, is interpreted as a person in a spiritual crisis; he is looking for the meaning of his life and thinking about the significance of death throughout the whole performance. Collisions of his spiritual perceptions of the meanings of life and death are different and deeply significant, supported by all the components of the performance, first of all, by philosophical conflicts, the dispute of Korkyt and Azrail. Korkyt is not willing to die, and (despite his asking for it) his parents, friend, and mistress also refuse to give their lives for him. Only his devoted wife agrees to die instead of him. The ironic Azrail (T. Kuraliev) calmly states that all are mortal because it is the law of life. However, everyone should find their life goal. At the end of the

performance Korkyt also comes to this conclusion. The maturity of his human 
spirit, the victory over himself and his biological essence transform Korkyt into a great sacral figure. B. Seitmamytov shows Korkyt's constant nervous tension. He renders the emotional perturbations in the character's spiritual life and, remaining subdued in all scenes, displays himself as a master of psychological game. Thus, he brings his character closer to the audience.

The spiritual greatness is, first of all, displayed in Korkyt's actions and his influence on the people around him. In search of his creative self and upon the will of the Absolute he becomes a great kobyzist. Bayterek (poplar) is a tree that he hews with an axe to make the instrument which gives incredible cosmic sounds. Having created the instrument, Korkyt immediately begins to play with great perfection and skill. His music subdues everyone, including Azrail, who is charmed by it and forgets about his initial goals.

The closeness to folklore is displayed in the following moment: the kobyz is made of Bayterek; in Turkic consciousness it is the world tree that unites the sky, land, and the underground world (the world of the dead). Thus, the sacral nature of Korkyt's image is revealed. The sacral nature comes from the Absolute and at the same time he comes to it as a result of his search for the meaning of life. The idea behind Korkyt's search lies in the fact that a human being should learn not to be afraid of life difficulties. The forty-year-old man, full of energy, rises above the crowd. He is a human being and at the same time a God's representative, chosen to be a mediator between people and the cosmos.

Exposing the theme of the crowd and personality, the stage director enriches the intention of the playwright. First of all, it is well expressed in plastic arts. In the course of the performance, the crowd is pushing Korkyt out of its environment, either absorbing or alienating him, or seemingly throwing him away. Further on, it is expressed in the existential social-psychological conflict. In some country the ruler has died, and people are in mourning. Korkyt, who has arrived there, is not aware of this. People ask him to revive Khagan (the ruler, impersonated by S. Zhylkeldiev). Korkyt appeals to Azrail with a request to return his soul, and begins to play his incredible music. Being subdued by the music, Azrail returns life to Khagan. He and the crowd even forget to thank Korkyt. The crowd welcomes Khagan and begins to worship him, i.e. the habitual relations between a ruler and common people are displayed. In addition, each of them pursues their concrete goals. The first words of Khagan after awakening to life are: "Where are my crown and my throne?" People begin to give him gifts and pester him. All of them immediately forget about the great cosmic event: Korkyt's belief in the Absolute, his powerful talent, and the great magic force of art, which helped him to get the soul of Khagan from the angel of death.

Thus, the stage director gives the spectator an idea about the behaviour of today's officials and office-seekers, as well as those who are engaged in pursuit 
of richness and different job positions. Their main goal is be on the top in any situations. Here the stage director blames the crowd for being unspiritual and aimless. The behaviour of the crowd reminds us of today's people, rushing to parties, meetings, and other 'soap bubbles' of social activity.

Any shocks (as death in this case) must spiritually and positively change humans, but both Khagan and the crowd still remain common people in the spiritual aspect, devoting themselves to the 'empty' goals just as it was a thousand years ago. The scenography of L. Tobasheva is simple, expressive, and extensional at the same time. In its depths the powerful blue waves of the sea are seen, merged together with the same light-blue sky. The connection between mortal and cosmic is obvious. Here from time to time a flashing light appears. Depending on the situation, this light embodies either the impact of the Absolute, or enlightenment, or the light of human mind, or a good impulse. Based upon this space, the scene area is a piece of land and people's existence here is perceived philosophically. The stage director metaphorically emphasises that people are always walking on the edge (of their graves). As regards Korkyt, it is expressed in the fact that wherever Korkyt goes, the grave is waiting for him.

Black stones on the seashore are another metaphor. From time to time they move, roll down on each other, and some of them emit light from within; sometimes a ray of daylight drops on them. The stones embody the nature, keenly reflecting the heaven's will. However, in certain spiritual-emotional moments of the performance, they appear as the embodiment of separate people, which in urgent situations are 'flamed' spiritually. At the same time the stones can be perceived as heavenly meteorites and as pieces of Caaba. It means that heaven and earth permanently and vividly communicate with each other, and that people should check themselves even in their daily lives, following the laws of moral world development. This is the unity of the cosmos and all the elements of being: people and heaven, steppe with its wildlife and plants, and stones. It seems that everything constantly interacts with the cosmos, either reacting to its signals or being rejected because of sluggishness. Another polysemantic metaphor of the performance is the abundance of big 'rolling stones'. This is not only the steppe reality, but the images of people, who imprudently follow the will of others and their unchangeable calculations. Moreover, the Kazakhs have a proverb saying, "The human head is Allah's ball". In other words, it is the recognition of human predestination. A howling wind is blowing on the stage and the 'rolling stones' are gathered either in one place, or roll in different directions. Depending on the scene's content, they convey a horrible impression of the feeling of spiritual loneliness, and of the understanding of life tragedy, thus causing suffering and pain. 
At the same time, the aggregate of metaphors and their meanings is expressed in Korkyt's spiritual feelings, and causes his desire at least to raise people's optimism, if only for a while, thus reviving connections with moral values that emanate from the Absolute.

The principle of earthly life limits, established by the Absolute, enables people to succeed in the implementation of their own life goals and tasks. The stage director and the scenic designer skilfully and unconventionally express this principle also in Azrail's dress. He wears a dark-red long chapan (men's coat), with a brown kerchief on the head, with crimson tassels, and a brown shirt and black boots. At first sight, it looks like daily clothes of a steppe dweller. However, scarlet wings make Azrail's figure sacral and ominous. They are seen, when he flaps his arms, from the sleeves down along the body. Each time, when the red wings are seen, the image of blood immediately appears, i.e. a thought of death that is always close. The dark colouring of the chapan and shirt intensify the horrible impression. It becomes clear at once that this is a routine appearance of the Angel of Death, who constantly sheds blood when he takes human souls. The fresh and old blood both show in the colouring of his dress. In the believers' perceptions Archangel Azrail sheds blood in the astral world in the very moment of human death. The stage director has made a brave step: he expresses this view in the dress colouring and red wings, which shock the spectator. This is both a psychological and a moral shock, which gives impetus to thinking about life and death.

In the performance only Korkyt can see the Angel of Death. The others cannot even suspect that this angel is quite close. This significant metaphor reveals the philosophical content of the stage production. T. Kuraliev opens the image of Azrail as an ironic person: he knows how miserable his attempts are to avoid death, so he is calm, confident, and internally laughs at the human efforts to avoid death. There is one disputable moment in the performance, connected with the image of Azrail. When the Angel of Death is about to take Korkyt's life, the latter gives him his kobyz. It means that the great sacral instrument that helps people and saves them is passed into the hands of death and taken away from life, i.e. it passes into Nothingness. The playwright has done it intentionally, in spite of the folkloric plot. In the tales about Korkyt, the kobyz is passed to the baksy (shaman), or, in other words, to an especially talented person; thus the kobyz and the relevant spiritual-aesthetic beginning prevail throughout ages. Iran-Gaip gives the kobyz into the hands of death, thus wishing to tell his contemporaries that presently the connection with the sacral world is lost and the world of people has turned out to be on the edge of an abyss.

Korkyt gives away the kobyz because there is no worthy successor close to him. This is an awful and distinct moral-psychological detail. The music of 
A. Raiymkolova is one of the main acting characters in the stage performance. It sounds from the very first minute of the performance up to the last one, changing the characters' mood and taking the spectators from the meditation to the premonition of tragedy. Its infernal sound has no analogues, and its magic nature has been given birth by the cosmos itself. Such an understanding is typical of the Turkic nations, and also of music specialists from the western and eastern countries. Empirically, it is confirmed by the personal experience of cosmonaut T. Musabayev: during two years of flights on the orbit he heard the melody of kobyz on several occasions.

The stage director J. Khadzhiev once again focused his attention on such phenomena as the role of a shaman in society and the meaning of kobyz music and the instrument itself. Thus, J. Khadzhiev restored the ethnic genetic, historical, and aesthetic basis of Turkic world outlook. The performance turned out to be integral and deep, with spectacular content, despite the fact that some actors' performance was superficial at times, and T. Kuraliev and K. Demesinov, who played the role of Azrail, sometimes descended to the level of communication with their partners.

The performance includes a whole complex of moral, social-psychological, philosophical, and worldview conflicts. The painful spiritual search of an individual is in the centre of the stage performance. The search is displayed as wide-scale and meaningful also because it shows the destiny of a genius, a meaningful figure, whose phenomenon is still waiting to be perceived.

In May 2002 this play was staged during the international festival of Turkiclanguage countries, Nauryz, in Kazan, where B. Seitmamytov, who played the role of Korkyt, received an award for the best male role.

The TYS continues to keep alive the traditions of the Kazakh theatre: a constant interest in folklore, historical and ethical-philosophical as well as psychological problems, attitude towards the stage language as an important instrument of spirituality (the use of monologues), devotion to the actor's psychological game, love of stage metaphor and symbols through the images of heroes, musical instruments, private possessions, weapons, etc. The political changes that are taking place in Kazakhstan, as well as the important spiritual and economic changes, require a search for new expressive means, innovation of the stage language, and a dialogue with the spectator. So, the Gabit Musrepov Kazakh Academic Theatre for Children and Youth is in constant search. 


\section{THE MEANING OF THE 'EXISTENCE PUZZLE' PERFORMANCE}

The well-known Kazakh film critic Bauyrzhan Nogerbek, who has studied the impact of folk traditions on the cinema, has defined several levels of screenfolklore relationship in a movie (Nogerbek 2010: 29). These are as follows:

The direct level - filming folkloric and literary works; the indirect interpretation level - creating films based on folkloric and literary works; the quotation level - when the understanding and inclusion of folklore fragments in the film structure take place organically, at the modern artistic thinking level. (Fomin 1983: 140)

Valeriy Fomin, when studying the ambiguous role of folklore, notes that "a folklore fragment is, in most cases, a complex and key metaphor, a kind of poetic mirror, in which the 'non-folk' part of the narrative is reflected; this part vividly reveals the hidden problems, conflicts, and new semantic values" (Yampolsky 1993: 61). The theatre situation is somewhat different. Theatrical art is the 'root bearer' of folklore traditions in the form of oral works and songs.

Kazakh folklore is full of ideas, images, and symbols, linked by epics, rituals, and games. Its means of expression include the word, music, movement, dance, plastic art, and improvisation - all that makes the theatre a modern phenomenon, with its specific staginess and originality. Comprehension of the theatrical nature through the play, folk music, and the plot is often linked with numerous signs and symbols. "The Kazakh music culture has traditions of such folk singers as 'sal' and 'seri', based upon contests of oral folklore genres and singing” (Khalykov \& Karzhaubaeva 2013: 217). Obviously, all the world theatres have similar experience; in other words, this problem is related to the world theatrical art and requires a comprehensive study, which implies a high level of generalisation. And, last but not least, the theatre has kept the original effective character of folklore plays. Every nation, in every period of its history, cultivates the art of performance, as well as acting, which corresponds to the realities and traditions of the society where it exists. It is connected with the evolution of social consciousness and with a certain set of resources (art, technology, etc.), which are inherent in a particular epoch. All researchers agree that "it is clear that the development of the theatre kept its originality and identity since ancient times, and thus the development of the theatre took place in all countries in the same ways, although in different historical periods. It had the same directions and genres: religious performances, oral-poetic tradition, folk or fair shows, performances of the so-called one-man theater" (Khalykov \& Karzhaubaeva 2013: 219). 
Folklore is a state of mind that is cultivated by people in their creative work, and has given life to people's substantial cultural development. Speaking about the social aspect of folklore as art, it can be called a living and inexhaustible source of all cultures. However, the action and the sound of folklore, which create the meaning of the game, are not the 'existence puzzle' in the postmodern sense; it is something profoundly different. Another thing is that philosophy and art are related to social, public relations, and public human existence.

Philosophy as something that is loudly expressed, visible consciousness, the theatre as the confirmation of sleepless existence and the art itself are the means of keeping and prolonging consciousness, which make the culture vivid. Without it, culture would transform into imitation, a frozen and dead collection of the monuments of culture. (Khalykov 2009)

The birth of consciousness, expressed as a performance at the theatre, just lies in the opening of this groundlessness of a human being, and the necessity to take one's own decisions. Being puzzled by existence, which stuck a human being in the very aggregate of its attentive habituation, perplexity dawned upon him with a strange light and the whole structure of his seemingly good routine life, as Anatoly Akhutin wrote, will prevail in his existence from now on (Akhutin 1997: 117). Thus, we see that game and seriousness do not exclude each other, and that the theatre, in particular, and the art, in general, do not simply evoke joyful feelings, but also provoke and suggest the Idea, which is the fundamental issue of human existence. According to Nietzsche's philosophy, "not only the limits, but the dignities of this Nietzsche's relation between philosophy and art, which are capable of searching the indescribable are beyond our abstract and scientific vision, the notion of tragic, and existential truth of life" (Nietzsche 1982: 544). The game's aesthetic and philosophical experience of the sharpened consciousness, astonishment, and amazement turned out to be in their aggregate as a single whole - spiritual search, in which the division into feelings, will, and thoughts is relative. As a philosophical text, these works of art are peculiar 'machines' of the intellect: their task, language, and internal 'arrangement' are called to 'suggest' the idea to a human being, to knock him out of the saddle of the ordinary language, cognitive and other stock-phrases, and to lead him into the awakening, gathered, sharpened, and attentive existence (Stefan-Sebastian 2013: 86).

Speaking about the idea of the 'existence puzzle' performance, we can see the question of the "Chronotope era when a person has no proper place in the world" (Borev 2002: 389). However, this is not the time and era of folklore predominance, or the era of the primeval culture. It is "the Topos Era, which implies the artistic space thinking and Man is on the stage, merging with nature: 
almost absolute dominance of nature over Man" (ibid.: 281). Nietzsche called the culture existing before the twentieth century - as Apollonia and the culture of the twenty-first century - Dionysian. Thus, the idea of the 'existence puzzle' performance is more suitable for deconstruction, absurdity, destruction, and other postmodern terms. Culture loses its human idea inherent in folklore along with sincerity, steadfastness, and constancy of being. After gaining abstract dimensions in human perception, the theatre has gotten tired of deconstruction and needs positive myths, legends, folklore heroes, and the real human art.

\section{CONCLUSION}

"The history of scenic art is always a dialectic interaction between the traditional and the new. The ratio of folklore and the new professional theatrical forms changed at different historic stages on the Kazakh scene" (Kabdieva 2002: 19). Folk traditions were still the factor that formed the Kazakh theatre. The Gabit Musrepov Kazakh Academic Theatre for Children and Youth became the place where dramatic stories of verbal folklore along with their problems, characters, and the imagery system became the basis of the Kazakh dramaturgy, and folk songs constituted a basis for the Kazakh opera and musical drama theatre, due to the unfading examples of musical folklore. This proves the fact that Kazakh folklore, which represents the content of the Kazakh national life, acquired universal significance, having assumed the noble mission of understanding and rapprochement between peoples. The traditional Kazakh Puppet Theatre Orteke (meaning 'a goat'), whose name originates from the galloping animal, playing the dombra (musical string instrument), embodies an intangible spiritual value, and it is also based on folklore. Orteke is recognized by UNESCO as a part of the world heritage, one of the spiritual values of the mankind. All kinds of arts revived by the young Kazakh artists are inspired by folklore, its symbols, and characters. The transformation of folklore is also widely used in modern popular music (Kazakh ethno-folk groups Turan, Ulytau, Roksanaki) and contemporary art (centre Red Tractor).

Globalising cultural signs show that the current state of human existence in culture reflects certain fragility, impermanence, and fragmentation. It means that the human being needs steadfastness, purity, and unselfishness. This can be derived only from art and folklore. As an important factor of cultural integration and an indispensable means of succession, traditional folk art has created and is still creating truly aesthetic and moral values. The present social and cultural situation is marked by a contradiction between the potential impact of the musical, visual, and verbal folklore heritage as a bearer of human values 
and aesthetic experience of the formation and development of social spiritual culture and the lack of a stable need of the younger generation to communicate with this type of national culture.

The problem of traditions and their interconnection with the culture of everyday life is of interest in cultural and art studies. The traditional world outlook of the Kazakhs remains the basis for the deep originality of the Kazakh theatrical, musical, and folkloric art, embodied in a complex of national ethnic and cultural traditions.

\section{REFERENCES}

Aiupov, Nurmagambed 2006. Tiurkskaia filosofiia: desiat' voprosov i otvetov. [Turkic Philosophy: Ten Issues with Answers.] Almaty: Kainar.

Aiupov, Nurmagambed 2012. Tengrianstvo kak otkrytoe mirovozzrenie. [Tengrianism as an Open World Outlook.] Monograph. Almaty: KazNPU im. Abaia. Available at http://tengrifund.ru/tengrianstvo-kak-otkrytoe-mirovozzrenie.html, last accessed on November 22, 2015.

Akhutin, Anatolii 1997. Rozhdenie soznaniia: Drevnegrecheskaia tragediia i filosofiia. [Birth of Consciousness: Ancient Greek Tragedy and Philosophy.] In: A. Akhutin (comp.) Tiazhba o bytii. Moskva: Russkoe fenomenologicheskoe obshchestvo, pp. 117-161.

Auezov, Mukhtar 2012. Kazakhskii epos i dorevoliutsionnyi fol'klor. [Kazakh Epic and the Pre-Revolutionary Folklore.] Available at http://el.kz/m/articles/view/ content-3510, last accessed on November 22, 2015.

Borev, Iurii 2002. Estetika: Uchebnik. [Aesthetics: Textbook.] Moskva: Vysshaia shkola.

Eleukenov, Sheriazdan 1987. Ot fol'klora do romana-epopei: Ideino-esteticheskoe i zhanrovoe svoeobrazie kazakhskogo romana. [From Folklore to the Epic Novel: Ideological-Aesthetic and Genre Originality of the Kazakh Novel.] Monograph. Alma-Ata: Zhazushy.

Fomin, Valerii 1983. Kino i fol'klor: stupeni vzaimodeistviia. [Film and Folklore: The Levels of Interaction.] Voprosy metodologii i metodiki izucheniia istorii sovetskogo teatra $i$ kino. [Questions of Methodology and Technique of Studying the History of Soviet Cinema and Theatre.] Kishinev: Shtiintsa, p. 75.

Heidegger, Martin 1997. Being and Time. Transl. by V. Bibikhin. Moscow: Ad Marginem.

Kabdieva, Saniia 1986. Fol'klornye traditsii v kazakhskom teatre. [Folk Traditions in the Kazakh Theatre.] Monograph. Alma-Ata: Oner.

Kabdieva, Saniia 2002. Kazakhskii teatr na kanune peremen. [The Kazakh Theatre on the Eve of Change.] In: S. Kabdieva (comp.) Sovremennoe iskusstvo Kazakhstana: problemy i poiski. [Contemporary Art of Kazakhstan: Problems and Searches.] Almaty: Fond Soros-Kazakhstan, p. 24.

Khalykov, Kabyl 2009. Bytie cheloveka v sovremennom iskustve: perfomansi i aksii. [Human Genesis in Modern Art: Performances and Acts.] Aktual'nye problemy 
gumanitarnykh i sotsial'nykh issledovanii. VII Regional'naia nauchnaia konferentsiia molodykh uchenykh Sibiri v oblasti gumanitarnykh $i$ sotsial'nykh nauk. [Topical Problems of Humanitarian and Social Study: Materials of the 7th Regional Scientific Conference in the Field of Humanitarian and Social Sciences.] Novosibirsk: Novosibirskii gosudarstvennyi universitet, pp. 176-180.

Khalykov, Kabyl \& Begalinova, Gulnara 2013. The Highest Art Tasks of the World and Humans Transforming. World Academy of Science, Engineering and Technology, Vol. 7, No. 5, pp. 558-567. Available at http://waset.org/ publications/4131/the-highest-art-tasks-of-the-world-and-humans-transforming, last accessed on November 22, 2015.

Khalykov, Kabyl \& Karzhaubaeva, Sangul 2013. Traditional Culture and Up-To-Dateness SPACE INTERACTION: Artistic and Cultural Processes in Kazakhstan. In: A. Sandu \& A. Caras (eds.) International Scientific Conference Tradition and Reform: Social Reconstruction of Europe, November 7-8. Bucharest: Medimond, pp. 217-220.

Mergaliev, Daniiar 2007. Fol'klorno-mifologicheskoe nasledie kazakhskogo naroda. [Folklore-Mythological Heritage of the Kazakh People.] Izvestie Altaiskogo gosudarstvennogo universiteta, Vol. 4, No. 3, pp. 129-131. Available at http:// cyberleninka.ru/article/n/folklorno-mifologicheskoe-nasledie-kazahskogonaroda, last accessed on November 22, 2015.

Nietzsche, Friedrich 1982. Daybreak: Thoughts on the Prejudices of Morality. Transl. by R. J. Hollingdale. Cambridge, UK: Cambridge University Press.

Nogerbek, Bauyrzhan 2010. Folklore Traditions in Kazakh Cinematography. San'at: Journal of the Academy of Arts of Uzbekistan, No. 1, pp. 58-61. Available at http://sanat.orexca.com/2010/2010-1/bauryrjan_nogerbek-2/, last accessed on November 22, 2015.

Nurpeis, Bakhyt 2010. Poiski kazakhskoi rezhissury v gody nezavisimosti. [Searches of the Kazakh Stage Direction in the Years of Independence.] Voprosy iazyka, literatury i iskusstva. Respublika Kyrgyzstan, Nos. 1-2. Bishkek: AVRASYC, pp. 262-267.

Satpaeva, Shamshiiabanu 2015. Kazakhskii fol'klor $v$ otsenke zarubezhnoi kritiki. [Kazakh Folklore in the Evaluation of Foreign Criticism.] Available at http:// bibliotekar.kz/shamshijabanu-kanyshevna-satpaeva-vejani/kazahskii-folklor-vocenke-zarubezhnoi-k.html, last accessed on November 22, 2015.

Ştefan-Sebastian, Maftei 2013. Philosophy as 'Artwork': Revisiting Nietzsche's Idea of a 'Philosophy' from the Point of View of the 'Artist'. Procedia: Social and Behavioral Sciences, Vol. 71, pp. 86-94. DOI:10.1016/j.sbspro.2013.01.012.

Yampolsky 1993 = Iampol'skii, Mikhail. Pamiat' tiresiia: intertekstual'nost' $i$ kinematograf. [Memory of Tiresius: Text Studies and Cinema.] Moskva: RIK Kul'tura. 


\title{
DISCURSIVE DEPICTION OF CUSTOMARY CONFLICT MANAGEMENT PRINCIPLES IN SELECTED AFRICAN PROVERBS
}

\author{
Mehari Yimulaw Gebregeorgis
}

\begin{abstract}
The objective of this study is to explore how proverbs of traditional African societies contribute to depicting the communities' conflict prevention and conflict management principles. To this end, proverbs collected from different parts of Africa, mainly Nigeria, Ghana, Cameroon, Republic of Congo, Botswana, Zimbabwe, Kenya, and Ethiopia were analysed using socio-semiotic approach to discourse studies and interpretive analysis. The findings of the study show that the proverbs of traditional African societies are instrumental in depicting the societies' conflict prevention and conflict management principles. Together with the 'prevention is better than cure' doctrine, taking communal responsibility, transparent truth-finding, participatory negotiation, win-win solution, and reconciliation and restoration of social harmony are among the traditional African conflict management principles that are portrayed through different African communities' proverbs.
\end{abstract}

Keywords: conflict, prevention, proverb, reconciliation, societies

\section{INTRODUCTION}

Conflict, which goes back to the origin of human beings, is "a relationship between two or more parties who have or think that they have, incompatible goals" (GIZ 2013: 13). It is exhibited at national, communal, and familial levels. Societies, groups, and individuals enter into disputes to control scarce resources such as power, money, and land. As long as individuals, groups, and societies continue to have socially structured clashes of interests and values, conflict remains part and parcel of human life. To illustrate this fact, the Ethiopians say: "Even the legs of one person get the friction of a quarrel" (Gira ena qegn egirm ygachalu) (ibid.: 19).

Despite its being an experience common to all races, there can be differences in the forms and levels of conflict in societies and in answer to them they have developed their respective conflict resolution mechanisms. The mechanisms can be formal or/and informal justice systems. Because they are culturally ap- 
propriate, economically affordable, and bureaucratically swift, informal justice systems "are the cornerstone of dispute resolution and access to justice for the majority of populations, especially the poor and disadvantaged in many countries, where informal justice systems usually resolve between 80 and 90 per cent of disputes" (Wojkowska 2006: 5-6). Aware of these merits, in 2004 the then UN Secretary General, Kofi Annan, indicated in his report to the Security Council that "due regard must be given to indigenous and informal traditions for administering justice or settling disputes, to help them continue their often vital role and to do so in conformity with both international standards and local tradition" (UN 2004: 12).

Customary conflict resolution mechanisms are not only methodically bound up with the social and economic realities of everyday life in traditional African societies, but are also strongly rooted in the culture and history of the people of the continent. Hence, "large segments of the rural populations, the overwhelming majority in most African countries, continue to adhere principally to traditional institutions" (ECA 2007: 1). In traditional African societies, rules in customary conflict resolution institutions are more dependable, better able to deal with conflict and accepted as legitimate. As a result, communities are more obedient to the customary rules (Nkonya \& Markelova \& Kato 2009). As much as they can, traditional African societies try to avoid having recourse to westernised justice systems. For example, the Yoruba of south-western Nigeria always pray: "Whether for good or bad may God not let us have a court case" (Atebi atare Olorun ma je a rejo) (Albert et al. 1995: 15). Aware of this, Kuruk states that "in no African country is customary law totally disregarded, or proscribed" (Kuruk 2002: 13).

Traditional African conflict resolution philosophies handed down from generation to generation have been a source of guidance on maintaining the peace and harmony of communities. As oral societies, traditional Africans have used folklore such as tales, idioms, riddles and proverbs to deliver their views on conflicts and their resolution mechanisms. These genres are instrumental in conveying what to do and what not to do for harmonious coexistence. From familial to communal levels, folklore is "mostly used to praise, to scold or appraise people's behaviour, hence promote or rather coerce accepted good morals among the people. The idioms, riddles and proverbs encourage people to adhere and strive for good societal moral values which in a way help them to be tolerant towards each other" (Moumakwa 2010: 42).

In doing so, proverbs, one genre of communicating traditional communities' conflict prevention and conflict management knowledge, are fused in discourse where and when appropriate as they are not learned and used separately (Yankah 2012). 
Proverbs can be studied from different perspectives as they have both areas of improvement and areas of strength. Different communities have proverbs which help to resolve conflict; equally, they have proverbs which portray prejudices on different sections of a society. For example, see Hussein (2009) and Yitah (2006) for gender stereotyping role of sexist proverbs in East and West Africa respectively. The scope of this study was, however, limited to the contributions of proverbs in resolving conflict. Specifically, the objective of the study was to explore how traditional African conflict prevention and conflict management principles are depicted in African proverbs.

Following the introduction, the conceptual framework of the study is discussed and the methodology is then presented. Based on the methodology, traditional African conflict prevention and conflict management principles depicted in their proverbs are analysed. Finally, concluding remarks are given.

\section{CONCEPTUAL FRAMEWORK}

A proverb is a medium that conveys numerous superior and compact ideas and beliefs. Although all societies use proverbs as a means of portraying their knowledge and life philosophies, their role for illiterate society in this regard is irreplaceable. "Proverbs have been used as disseminators of traditional wisdom, knowledge and apparent truths that are handed down from generation to generation, especially in the absence of vigorous written literature" (Degnew \& Wodajo 2014: 94). Though proverbs talk about human beings, like other folklores, they are metaphorical narratives based on animals, plants, people etc. Rich vocabulary, graphic statement, allusions, association and comparison are the main language features of proverbs (Adeyemi \& Salawudeen 2014).

Finnegan (1970: 390) says that "in many African cultures a feeling for language, for imagery, and for the expression of abstract ideas through compressed and allusive phraseology comes out particularly in proverbs". Similarly, Adegoju (2009: 58) opines that proverbs are employed to "communicate truths that may be abstract and difficult to grasp, as they usually dramatize and configure the bare truths in the facts of everyday life. Through this, such truths become so substantial that they stimulate imagination and challenge our understanding of situations". As a result, proverbs enhance the pragmatic effect of the speaker's communicative intent, clarity, and taste. The Ethiopians say, "As tej (Ethiopian local beer made of honey and hops) is drunk using brelee (a round vase-shaped container made of glass), a matter is discussed using proverbs"1 (Neger bemsale tej be bril). The analogy here is between breele, the container, and proverb, the medium. As brelee is the appropriate container for drinking the local beer, 
proverbs are a suitable medium for discussing issues. Otherwise, as the Oromo of the same country say, "A speech without a proverb is like a stew without salt" (Dubbiin mammaaksa hin qabne ittoo sooqidda hin qabne) (Hussein 2009: 97). Here, the analogy is between salt and a proverb. As a stew is made delicious by adding salt, conversation is made interesting by employing proverbs. In this regard, the Nigerians explicitly say, "Proverbs constitute the spice or salt of human communication" (nnu e ji eri okwu) (Oraegbunam 2009: 58).

As a repository of traditional African knowledge, philosophy, customs, ethical standards, morals, and wisdom, proverbs have a vital educational function. "Proverbs are central to indigenous education and various themes of traditional education were imparted through the vehicle of proverbs" (Adeyemi \& Salawudeen 2014: 188). They instigate reflection and invite deeper thinking and consideration of issues. They help to shape the sentiments, views, and moral awareness of one's audience. Aware of these benefits, traditional leaders and mediators ${ }^{2}$ use proverbs to exert a strong moral force and correct social wrongs. As Olatunji clearly states, the use of proverbs to teach socialisation and deterrence is prescriptive. They "outline a rule of conduct. They state what should or should not be done and lay conditions for certain actions and attitudes. They serve as social charters condemning some practices while recommending others" (Olatunji 1984: 175).

As a part of the indigenous knowledge systems entrenched in the cultural practices of communities and communal wisdom, intellectualism and morality in conflict prevention and conflict management are often conveyed through proverbs. Properly used, conflict prevention and conflict management proverbs are tough to refute; instead, they make people think critically about their view of the matter. In this way, proverbs serve as a "law that regulates societal codes of conduct. This makes them not only persuasive but useful in preventing conflict from happening and stopping conflict once it would have broken up" (Makamani 2013: 8). In conflict prevention and resolution, African proverbs are instrumental in providing speakers with a medium through which to realise a variety of communally anticipated goals. They are used as tools to persuade when settling disputes; teach communal morals; expound lessons of good and evil; give guidance on right actions and explain the need for and benefits of mutual understanding and peaceful coexistence.

For example, the following authentic martial conflict resolution scenario from Urhobo community of Nigeria in Ohwovoriole (2011: 126-128) clearly depicts how discourse participants employ proverbs as salt or spice with the aim of adding the persuasive effect on their discourse. 


\section{Conflict resolution scenario 1}

Cause of conflict:

Discourse participants: financial problems of the family

- wife, trades in corn and runs a little poultry business

- husband, an assistant driver

- six mediators (four male and two female relatives)

Venue: husband's family

The dialogue was held on a family issue among the discourse participants mentioned above. The husband, who had been trained in poultry business but preferred to be a driving assistant, had given the responsibility of the poultry business to his wife. But his wife did not like the idea and she wanted her husband to come back home and run the poultry business himself. She was urging him to do so with the help of the mediators. Hereafter, the dialogue between the participants went on as follows:

1. Woman: I no longer understand what my husband is doing. You are all witnesses that he

2. only came home because of the injury that almost took his life. He has left the care of

3. the family to me. One finger cannot pick up louse from the head. He spends his time and

4. money on mistresses that give him incurable diseases. I want to know

5. why he neglects the children and me.

6. Man: Are you now the man in this marriage?

7. Woman: I am a woman. Why should I do the work a woman should do as well as that

8. which a man ought to do? I will not run that poultry again.

9. Man: (retorts in anger) I am your husband and you must not forget that I am the one to

10. make all the decisions in this union and your duty is to obey. Have you ever asked why I

11. had to take up the assistant driver's job? A person who has one finger pointing at

12. another has three pointing towards himself.

13. 1st Mediator: My brother, the hand of the squirrel should not deny one of the

14. elephant's thigh. I do not see the sense in your neglecting your lucrative poultry

15. business and staying away from your family for the most part of the year. Husband, do this

16. so that I do that and that makes the home peaceful. I am not against you, but remember,

17. when the roots of a tree begin to decay, it spreads death to the branches.

18. 2nd Mediator: My child, your words are hard and are not expected from a sensible

19. woman like you. This is not enough for you to fight over. If a man sees a snake and a

20. woman kills it, it is all right as long as the snake is killed. The husband and the

21. children are yours. You should not use your mouth to bring them bad luck. When the 
22. earthworm pays respect to the soil, it opens for it.

23. 3rd Mediator: My people, my sister needs to be encouraged here. Taking care of five

24. children alone is not easy. One who defecates on the roadside gives room for the

25. passers-by to curse him. Six months ago the baby had chickenpox and was admitted to

26. hospital. The doctor and nurses kept asking for the child's father and he never came in

27. spite of several messages sent to him. My sister has her goods to sell in addition to

28. running the poultry. If one cannot help the wife to carry her load, one should not

29. add to the burden.

30. 4th Mediator:

My people, "This is not enough for you to fight over" makes the fighter angry.

31. When will my son learn that assistant driver's job is dangerous and unprofitable?

32. Whenever the vehicle breaks down on a long journey, you have to spend the night in it

33. instead of the comfort of your bed. The sooner you resign from this job and return, the

34. better for you and your household. I understand the poultry business is lucrative. If

35. properly managed, whatever income received from it should be enough to maintain your

36. family. A person carrying an elephant home on his head need not use his toes to dig

37. up cricket on the way. Come home and take care of your wife and your children. This

38. will please all of us here. When a child is given what she has been clamouring for, her

39. restlessness disappears. I hope I have spoken the mind of everybody here, but I want

40. him to respond.

41. Man: My elders, I thank you very much for this meeting. You need only tell a child a

42. phrase and he completes the sentence. I have heard all you have told me. I promise to

43. give up the job in another two weeks after I have collected this month's salary from the

44. company.

Using proverbs, disputants are pressed to overcome their feelings of resentment and anger, which lead to retaliation, accusations, and counter-accusations. They are urged to forgive each other and restore peace (Ohwovoriole 2011). They are further encouraged to concentrate on tolerance and mutual aid, which restore and sustain communal peace. In this regard, Akinmade (2012: 128) argues that proverbs "perform diverse functions, ranging from bringing peace where there is conflict and misunderstandings, giving hope where there is despair and light where there is darkness in human relationships and interactions". 


\section{METHODOLOGY}

A qualitative research methodology was used to explore how proverbs of traditional African societies contribute to depicting the communities' conflict prevention and conflict management principles. In the genre of qualitative research, this study specifically employed the socio-semiotic approach to discourse studies and interpretive analysis. While the latter adheres to analysis of discourse to discover what social beliefs it constructs and what social actions it performs, the former, according to Renkema (2004), advocates that social context is fundamental in the study of discourse. Halliday and Hasan (1985) argue that there are three concepts of discourse that help us interpret the social context: the field (social action in which a participant is engaged), tenor (participant in the social action), and mode (what role the language plays). In this study, conflict prevention and conflict management, disputants and mediators, and proverbial discourse as a means of conveying conflict prevention and conflict management principles are understood as the field, tenor, and mode respectively.

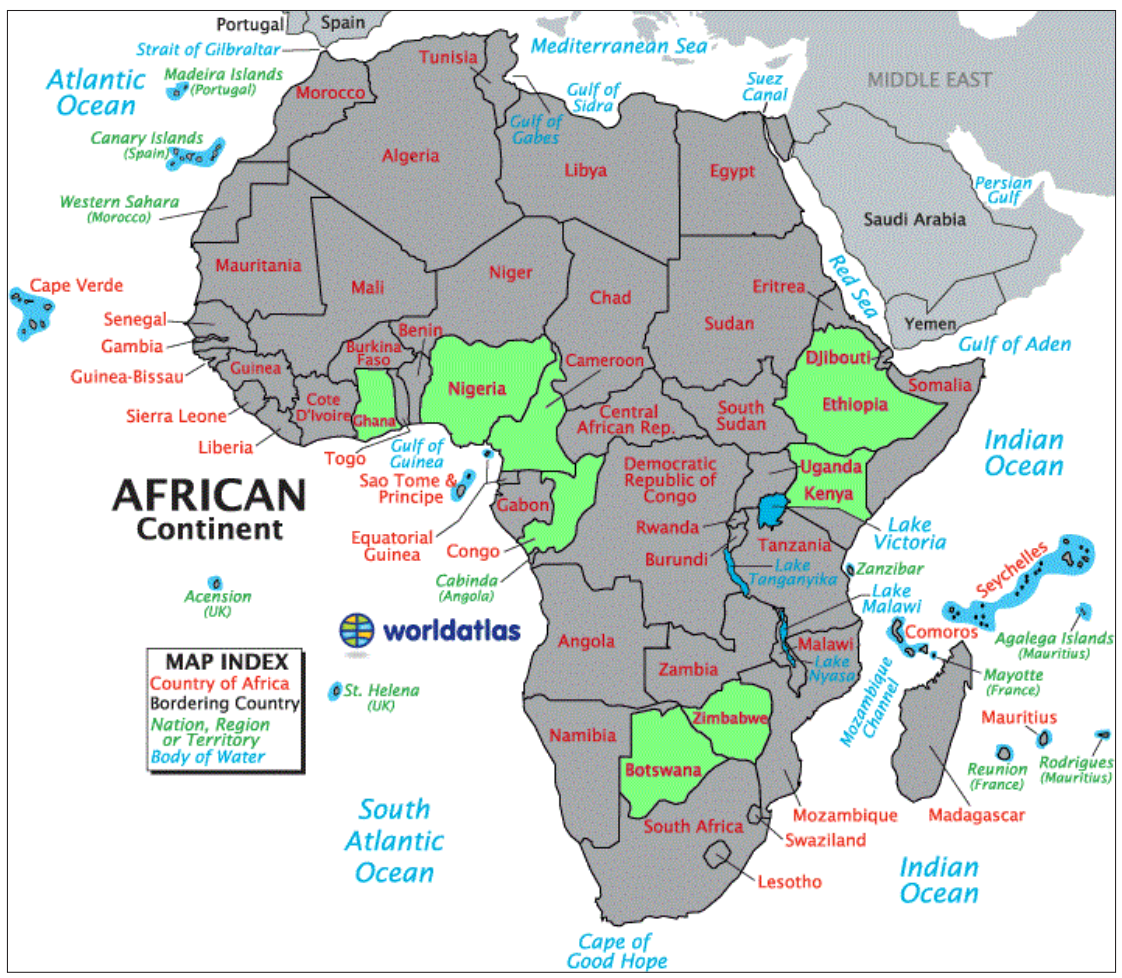

Figure 1. Locations of the main sources of data across the continent (http: / / www.worldatlas.com / webimage/countrys / africa/africaa.htm). 
Through convenience sampling, published and unpublished resources on traditional African proverbs were accessed. First, more than 400 proverbs were grossly collected mainly from: Nigeria, Ghana, Cameroon, Republic of Congo, Botswana, Zimbabwe, Kenya, and Ethiopia. Then, through purposive sampling, 110 proverbs on conflict and its prevention and management principles from all the main data source countries were selected for analysis.

In this study, language is understood as part of the major social processes and activities which construct social reality. Along with this, in the course of analysing discourse to discover what social reality and ideology it represents, discourse is defined as "the interrelated sets of texts and the practices of production, dissemination and reception that bring a particular version of social reality into being" (Porter 2005: 3); hence, the role of language in the process of constructing social beliefs about conflict and the means of preventing and managing it is drawn. In other words, traditional African discourse conveyed through proverbs on conflict prevention and conflict management was analysed to discover what social action it performs and what social reality it constructs. In this way, the study elucidates how traditional Africans use their proverbs to impart their conflict prevention and conflict management principles.

As employing proverbs requires seeing one thing in terms of another, aiming at more vividness, the analysis and interpretation were made considering the appropriateness of the context in which the proverb was used. Specifically, the relationship and fitness of the proverb to its referent in the social context were considered. In fact, the micro-analysis was made with the assumption that the multifaceted social, cultural, ideological, and societal structures which affect the proverbs' production and interpretation are the macro-context in which the proverbs exist.

Every traditional African community has its own sound conflict prevention and conflict management institution. Although they are sensitive to the sociocultural situations of the participants, most traditional African conflict prevention and conflict management mechanisms display common features. One medium for depicting these shared principles is folklore. The following section discusses how selected proverbs from different African societies portray their principles of conflict prevention and conflict management.

\section{CONFLICT PREVENTION}

Traditional African societies understand that human beings are social animals. One cannot live without the support and recognition of others. According to Kaphagawani (2006), quoted in Mandova \& Wasosa (2013: 876), their motto, 
"I am because we are, and since we are therefore I am", clearly depicts their philosophy. In line with this, Olateju further explains:

The inherently African semantic field of ubuntu provides a good example in this regard. It signifies a socially caring and sharing way of thinking and living, which is well captured in the rhyming Xhosa expression, Umntu ngumntu ngabantu [sic]. Literally this means that a human being is a human being through human beings. Or, paraphrased, a human being becomes a true human being through her/his relationships with other human beings. Similar or comparable expressions are found all over Africa. (Olateju 2013: 234)

Indeed, regardless of its different linguistic form, this principle is found in almost all traditional African societies. For example, the Tigray from Ethiopia assert that "The cure for human being is a human being" (Nisbis ya medhanit seb).

Hence, traditional African societies believe that full intention and commitment to accept and respect the humanity of the other is a precondition for peaceful coexistence. They understand and sense others' interest as the others do for them because, as the Urhobo community of Nigeria say, "When the earthworm pays respect to the soil, it opens for it" (Ohwovoriole (2011: 127) (see the conflict resolution scenario 1 , Nos. $21 \& 22$ ). In order not to spoil this healthy relationship, 'prevention is better than cure' is the fundamental principle of most of traditional African conflict prevention and conflict management institutions. For example, the Amhara say, "Take care instead of suffering the consequences" (Tamo kememaqeq askedmo metenqeq).

One source of conflict, according to traditional African societies, is opening a space for dispute. In this regard, the Yoruba from Nigeria say, "If the wall does not open up, the lizard will not be able to enter" (Bi ogiri ko la nu, Alangba ko le r'aye wo be) (Abayomi 2014: 2). In the same way, the Amhara say, "Hyena enters through a way paved by dog" (Wusha beqededew jib yigebal). Both proverbs are laden with imagery. While lizard and hyena are metaphors for something evil that causes conflict, the hole in both proverbs is a metaphor for misunderstanding between disputants. So, the lesson drawn from these proverbs is, "Do not leave space for conflict". As leaving a physical space allows lizard and hyena to enter, leaving space for misunderstanding will lead to dispute.

In order to close the space for conflict, communities need to predict potential sources of conflict. As the Africans say, it is then that they will overcome them. "You can only jump over a ditch if you have seen it from afar" (Malunga \& James 2004: 5). The ditch here symbolises a potential source of conflict. In line with this, traditional African societies understand that not being able to keep the required physical and relational distance is one source of conflicts. To 
express this social truth, the Nigerians and the Cameroonians say, "Familiarity breeds contempt; distance breeds respect", and "Do not step on the dog's tail, and he will not bite you", respectively. In the latter, a dog is a metaphor for another person. As a dog does not bite you as long as you do not touch its tail, by extension, a person does not attack you if you refrain from attacking him/her.

When there is misunderstanding, violent conflict resolution mechanisms are not advised as a solution. Instead, communities encourage solving the problem through discussion. For instance, this belief is clearly portrayed in the following proverb from Botswana: "The greatest fight is verbal" (Ntwa kgolo ke ya molomo) (Moumakwa 2010: 43). Correspondingly, the Kenyans say, "A man who uses force is afraid of reasoning". Furthermore, to succinctly indicate the relevance of being careful to maintain peaceful relationships, the same people say, "Do not say the first thing that comes to your mind". The reason for urging people to think before they speak is also clearly captured in the Yoruba proverb, "A good word may bring forth kola nut from the pocket while a bad one may bring forth the arrow from the scabbard" (Iwo ti o ka sa igi, liagbe, ti, okota ogure lofa, ti ode idi opeti ogbe enu s'oke ope nrol' asan ni) (Obisakin 2010: 55). Similarly, the Oromo of Ethiopia promote non-violent communication by saying, "Good words are better than good bedrooms" (Afaan gaariin hafaa gaarii caala) (GIZ 2013: 56).

Generally, in their effort to prevent conflict, traditional African societies are aware of the need for patience. That is why the Fulbe people who live in West, Central, and East Africa say, "Patience can cook a stone" (Munyal deefan hayre) (Afriprov 2005: 1). Here, a stone is a metaphor for a problem which in the beginning looks irresolvable. Therefore, the lesson being conveyed in this proverb is that there is no problem that cannot be solved as long as there is patience.

\section{CONFLICT MANAGEMENT}

Regardless of their effort to prevent, traditional African societies discern that conflict is part and parcel of being human. For example, the Zimbabweans say, "Committing a crime is not associated with a tree but with human beings" (Mhosva haiwiri pamuti asi pamunhu) (Mandova \& Wasosa 2013: 875). Again, the Batswana (citizens of Botswana) say, "A wrong does not decay; it is the meat that decays" (Moumakwa 2010: 59). By this, they mean that social conflict is natural. The remedy is acknowledging this social reality and addressing it peacefully whenever it happens (Phillips 2011).

Traditional African societies believe that a conflict has to be managed as soon as possible. To remind us of this, the Kenyans say, "Those who get to the 
river early drink the cleanest water". If a conflict is not managed within a short period of time, the problem will become large and complex. In this regard, the Ethiopians believe that "evil penetrates like a needle and then becomes like an oak tree". Likewise the Zimbabweans warn us that if a conflict is not resolved as soon as possible, it will be exposed to third-party interference: this is captured in their proverb, "Slowness is of the leopard; the hyena ate in transit" (Chinono chikave chengwe; Bere rakadya richifamba) (Mandova \& Wasosa 2013: 875). So, as the Yoruba say, "One dares not go to bed with the roof on fire" (A ki $i$ finá sórí òrùlé sùn) (Adegoju 2009: 63). In this regard, the Amhara say, "Put out the fire before it destroys" (Sayqatel beqtel) (GIZ 2013: 77).

Traditional African societies, however, do not like to turn to West-oriented justice systems; according to Ayittey (1991), quoted in Phillips (2011: 149), they believe that "establishing guilt and executing retribution and punishment without reference to the victim or the wider families or future reincorporation of the offender into the community" are not good for lasting peaceful coexistence of communities. The same belief is held by the Yoruba, who say, "Litigants do not return from the court and remain friends" (A kii ti kootu bo ka sore) (Phillips 2011: 149).

Traditional African societies rely on their customary conflict resolution institutions. They believe in discussion. For example, the Batswana say, "The good of the conflict is discussion" (Molemo wa kgang ke go buiwa) (Moumakwa 2010: 43). Similarly, the Kenyans understand that "having a good discussion is like having riches". Wise mediators and community leaders are responsible for settling disputes through mediation. The Yoruba people say, "One never hears 'beat him up' from the mouth of an elder" (A kii gbo "lu u" lenu agba) (Adeyemi \& Salawudeen 2014: 190). The following sub-sections discuss in more detail how traditional African communities employ proverbs in applying their conflict management principles.

\section{COMMUNAL RESPONSIBILITY AND TRANSPARENT TRUTH-FINDING}

In sociocentric traditional African communities, conflict is not seen as an individual issue. Kaphagawani (2006), quoted in Mandova and Wasosa (2013: 876), argues that most traditional African societies share the view that "whatever happens to the individual happens to the whole group, and whatever happens to the whole group happens to the individual". Be it on the side of the accused in taking responsibility for the damage or on the side of the victim in reacting to the offence, issues are handled at communal level because, according to the 
Cameroonians, "Rain does not fall on one roof alone". The message conveyed through the proverb is that the impact of an event on an individual, be it good or bad, has a certain impact on the other members of the community as well. With this understanding, the family or community is accountable for the offence committed by its member. By the same token, the family or community is expected to defend a member who is a victim (Kuruk 2002). The reason for this solidarity, according to the Ethiopians, is, "A single stick may smoke, but it will not burn". There are also different versions of the proverb from different countries. The Nigerians say, "One finger cannot pick up louse from the head" (Urhiobo ovo se muee ishuu) (Ohwovoriole 2011: 132) (see conflict resolution scenario 1 , No. 3). In the same way, to underscore how a collective response to a problem is a force which makes it possible to speak, to be listened to and eventually to solve the problem, the Congolese say, "A single bracelet does not jingle". In all the aforementioned proverbs, the single stick, one finger, and the single bracelet are metaphors for an individual member of a community. Showing the individual's inability to solve big challenges alone, traditional African communities advocate the benefits of cooperation in resolving the conflict. In this regard, the Ethiopians say, "When spider webs unite, they can tie up a lion" (Dir siyaber anbesa yasr). Here, individuals are symbolised as weak as a single spider web. The lesson in this proverb is that as the webs brought together could tie up a lion, united individuals can solve a difficult problem. Beyond safeguarding the disputants, collective responsibility is preferred to individual accountability for a smooth settlement of the dispute, as we can learn from the Swahili proverb, "Where there are many, nothing goes wrong".

When they start discussion on behalf of an offender from their group, Amhara mediators often say, "A cow gave birth to a fire: she wanted to lick it, but it burned; she wanted to leave it, but she could not because it was her own child" (Lam esat welda endatlsat aqatelat endattewat weldat). In the proverb, the lawbreaker is symbolised by a fire while his or her family or clan is represented by a cow. Mediators quote the proverb to preach the community that they should defame the wrongdoer and take collective responsibility eventually. The proverb also indicates that the family or the clan that takes the responsibility for it has no choice as long as the wrongdoer is a member of the unit. To declare the family's or the clan's willingness to take responsibility for the offence committed by their member, the same community says, "A cow's horns are not heavy for it" (Le lam kendwo aykebdatme). In the same vein, the Zimbabweans say, "An elephant's tusks are never too heavy for it". Here the offending member is symbolised by the horn of the cow / tusk of an elephant to show that as no part of the body is too heavy for the individual to carry, a clan/family member is a part of the community and cannot be a burden for the group. In traditional 
African societies, whatever mistake you make, your family or clan members are on your side to share your problem and to co-own the solution.

Once the accused side takes responsibility, mediators discover the root cause of the conflict through investigation. To this end, mediators encourage disputants to be open and honest in telling the real cause of the dispute. In doing so, the Amhara say, "Fetch water from the source; verify the matter from deep within" (Negern kesiru wuhan ketiru) (GIZ 2013: 31). Otherwise, as the Tigray from the same country say, "He who conceals his wound hides medicine for his wound" (Habaeya quslus habae medhanitu).

Mediators also use other proverbs to further urge disputants to tell the truth. For example, the Tigray say, "Truth may get thin but it won't be wrecked" (Haqis tqetin ember aytbtekn). The Batswana add, "Ninety-nine lies may help you, but the hundredth will give you away". The Cameroonians' version of this wisdom is, "Lying can get you a wife, but it won't keep her". The abovementioned proverbs say that regardless of the time it takes, the truth will be revealed eventually. As the Cameroonians say, "The darkness of night cannot stop the light of morning". Here, darkness and light are metaphors for lies and truth respectively. The Tigray warn an alleged liar that "Food carried for a certain trip, and liars, gradually get lighter" (Sinqin hashawin endahader yqell). Here, the analogy is between the gradual reduction of the weight of food consumed on a journey and the eventual untrustworthiness of a liar.

Mediators employ these proverbs to preach that unless the real cause of the problem is identified, a lasting solution cannot be found. If the peaceful dispute resolution process is to come up with a real solution, disputants have to honestly reveal the real cause of their problem. By doing so, disputants can proceed to mutual understanding and common ground, which are crucial to resolving the dispute. In this regard, the Oromo from Ethiopia say, "People can agree when they understand one another well" (Yoo waligalaan alaa galaan) (GIZ 2013: 46).

In the course of an examination, in Botswana, for example, mediators and leaders make the disputants sit in front of them so that they will have eye contact with them. Mediators do this for they believe that "words are easily spoken out when facing each other" (Mafoko a matlhong) (Moumakwa 2010: 53), and the Amhara say, "Discussants communicate well through facial expression" (Negre beayin yigebal). This strategy helps to monitor disputants' body language in order to discourage them from telling untruth. Following the establishment of truth, the conflict management process proceeds to negotiation, solution, and reconciliation. 


\section{PARTICIPATORY NEGOTIATION, WIN-WIN SOLUTION, AND RECONCILIATION}

In traditional African conflict resolution institutions, mediators or community leaders do not simply impose their decision on disputants. Instead, they allow participation by those attending the court hearing in general and the disputants in particular. The general public is invited to put forward their comments on any aspect of the process. In this regard, the Batswana say, "Everyone has a right to say what they think" (Mmualebe o a bo a bua la gagwe). Speakers are not judged for whatever they say at the trial because the same people believe that "all said at the kgotla (a customary conflict resolution institution in Botswana) is beautiful" (Mafoko a kgotla a mantle otlhe) (Moumakwa 2010: 24). The Zimbabweans' version of this wisdom says, "A court knows no fool" (Dare harina benzi) (Mandova \& Wasosa 2013: 876). The proverbs denote that everyone's contribution to the traditional court proceedings is valued and respected on the understanding that it is the individual's right to voice whatever opinion they have. These practices help traditional African communities develop a sense of owning their respective traditional conflict resolution mechanisms and strengthen their ties and accountability to these institutions' ethos.

After the victim of the conflict is soothed, the mediators set the stage for disputants to meet face to face. Based on the principle demonstrated in the African proverb, "A mother of twins must sleep on her back" (Malunga \& James 2004: 5), mediators work to embrace both the victim and the offender. They do so by encouraging both sides to be morally upright people who demonstrate good manners, helpfulness, concern, compassion, sincerity, and so on (Moumakwa 2010: 41).

Disputants are allowed to present their positions (their mutually exclusive demands), interests (the motivation underlying their demands), and needs (their requirements) (GIZ 2013: 31). In the course of negotiation, however, mediators urge disputants to adhere to non-violent discussion focusing on decreasing tension, blame, and counter-blame. In this regard, the Zimbabweans say, "A court does not condemn an individual but it condemns the crime" (Dare harizonde munhu, varume dare rinozonda mhosva) (Mandova \& Wasosa 2013: 876). They advise disputants to restrain themselves from using bad words. For example, the Yoruba people say, "It is your utterance that will determine the reply that you get" (Isoro ni igbesi) (Obisakin 2010: 44). Mediators counsel disputants to restrain themselves from pointing fingers at one another. In this regard, the Nigerians adhere to the belief that "A person who has one finger pointing at another has three pointing towards himself" (Ohwo re onie uriobo ovo ke ohwofa vwe era onie koma roye) (Ohwovoriole 2011: 127) (see conflict resolution 
scenario 1, Nos. 11-12). Likewise, the Zimbabweans say, "The monkey does not see his own backside; it sees its neighbour's". By saying so, mediators try to make the disputants look at themselves instead of pointing a finger at their opponents.

Disputants, particularly the victim of the conflict, are urged to accept the peaceful way of dispute resolution for the sake of innocent others and the community at large. Mediators persuade the victim to overcome his/her hatred, antagonism, and vengeful desires. In doing so, they say, "If you close your eyes because of the bad people around you, you will not see the good people passing by". In this Africans' proverb, closing the eyes represents refusing to solve the problem through peaceful negotiation.

If disputants refuse to attend a peaceful discussion and utter further provocative words, mediators, for example, in Zimbabwe reprimand them by saying, "If your mouth were a knife, it would cut off your lips". Ethiopian mediators also discourage disputants from speaking too much, saying, "The fool speaks, the wise man listens". Besides, the Cameroonians say, "A chattering bird builds no nest". Moreover, if disputants keep on resisting the mediators' advice, they could be warned by the Africans' proverb, "Ears that do not listen to advice accompany the head when it is chopped off".

When one of the disputants shows resistance to a peaceful settlement of a dispute because he/she and/or his/her group is more powerful than his/her opponent, the Shona people from Zimbabwe warn that "every power is subject to another power". Hence, as is said by the Ethiopians, "What is inflated too much will burst into fragments". If mediators think that disputants are showing resistance because they are being manipulated by other parties, they tell them not to be the tools of others, using proverbs like the following from Botswana, "A fool and water will go the way they are diverted".

When mediators advise a public figure or a head of a certain institution, they give due emphasis to the implications of his/her wrongdoing for other people around him/her. For example, the Urhobo from Nigeria say, "When the roots of a tree begin to decay, it spreads death to the branches" (Esiri urhe de gbo ko orue omen e neje) (Ohwovoriole 2011: 127) (see conflict resolution scenario 1, Nos. 16-17). Here, while the root symbolises a senior person, head, etc., the branches connote subordinates of the senior or head. Moreover, there are instances when the offending elder or leader faces serious criticism using proverbs, for he/she has failed to be a role model for his/her community. In this regard, Yankah (2012: 50) has documented his actual observation of such an occasion as presented below. The proverb (see conflict resolution scenario 2, Nos. 3-4) along with the discourse was spoken, following the failure of a 70-year-old man to utter the Great Oath of the community, presented by a 40-year-old plaintiff 
who accused the defendant of illegally farming his piece of land, for claiming the land.

\section{Conflict resolution scenario 2}

Interaction: judicial proceedings

Size of audience: $\quad 60$ or more

Proverb speaker: man, 60 years of age

Place: $\quad$ Kumasi (palace of the king of Asante)

\section{Original language: Akan}

You, elder X,

1. I remember you were once a sub-chief. By the grace of the ancestors, you were

2. once the Yokohene of -----. You yourself know you are elder; apologies, the

3. elders have said, the forest bird may be pardoned, if it doesn't know that rice is

4. edible grain; but bird of the grassland has no excuse. If one should be ignorant

5. of tradition, it should not be an elder like you. You were once a sub-chief; a land

6. claim has been backed by the Great Oath and you, of all, still encouraged your

7. wife to plough the land; an elder like you, what is your worth if you hold the

8. Great Oath in contempt? You are guilty!

In the proverb, a person who makes a mistake deliberately is symbolised by a bird of grassland, while a person who makes a mistake unknowingly is represented by a forest bird. Hence, the lesson is that a person who makes a mistake deliberately will suffer the consequence.

This being so, traditional African societies give due emphasis to a win-win solution of a dispute. They try to identify the interests of both parties and they work to come up with a solution which fairly satisfies both sides (Ohwovoriole 2011). In their efforts to advance a win-win principle of conflict resolution, the Oromo from Ethiopia say, "For the lake not to dry, for the frogs not to die" (Akka Haroon hin gonne akka raachi hin dune) (GIZ 2013: 22). By the same token, the Igbos from Nigeria say, "Let the kite perch and let the eagle perch also, whichever denies the other its perching right, let its wings break off..." (Egbe bere ugo bere nke si ibe ya ebela nku kwapu ya) (Oraegbunam 2009: 58-59). Here, the lake, frog, kite, and eagle connote disputants. Both proverbs emphasise the necessity for negotiation which leads to a win-win solution.

To this end, disputants are usually urged to compromise some of their positions and focus on give-and-take for the sake of peaceful coexistence. That is why the Tigray say, "For the safety of the clay oven, let the rat pass by" (Menti eta mugogo tihlef eta enchiwa). The aforementioned proverbs are used to advo- 
cate the relevance of considering the demands of others to achieve successful reconciliation that realises peace and harmony. They promote this view for they believe that as the Kenyans say, "There is no cure that does not cost". Compromising someone's demand for the benefit of the other side and the community at large means that both parties, along with the mediators, can negotiate fair agreement that can satisfy both sides as well as the community as a whole.

In fact, if the truth-finding process has found that one person/group is clearly a victim while the other is clearly an offender, compensation may precede apology and forgiveness. Depending on the level of damage, a victim may be compensated by the offender. In this instance, the offending group employ collective compensation; they believe that, as the Ethiopians say, "Fifty lemons are a load for one person, but for fifty persons they are perfume" (Amsa lomi leand sew shekmu leamsasew gin gitu). In this context, the lemon is a metaphor for the offender's burden of paying compensation. The proverb expounds that collective compensation is vital in lightening the burden of an offender while developing a sense of belonging for community members who contribute something to the compensation. This way, they strengthen their group solidarity. Otherwise, if a member of a community fails to share the problem now, all the burden will fall on him/her in case he/she faces a similar problem in the future. To advise community members not to risk this challenge, the Tigray say, "One who eats alone, dies alone" (Beynu ya zibli'es Beynu yimewut). The Zimbabweans also use the same expression in the same context.

The ultimate goal of traditional African societies' conflict resolution process is, however, restoring peace and harmony among the disputing groups in particular and the community as a whole (Olateju 2013). Justice for traditional African communities is apology, forgiving and forgetting and eventually restoring social relations in the interest of peaceful coexistence (Ohwovoriole 2011). Vengeance and malice are not part of their notion of justice (Oraegbunam 2009). In this regard the Yoruba warn that "it is sickness that can be cured, as we cannot cure death" (Àisàn làá wò, a kì í wo ikú) (Adegoju 2009: 63). By this, they mean that plotting murder as revenge causes irremediable fatal damage.

As the Kenyans say, "After a foolish deed comes remorse". Hence, moving towards settling a matter, offender's regret for his/her wrongdoing is conveyed through his/her apology. At this juncture, the Congolese say, "Lower your head modestly while passing, and you will harvest bananas". The Batswana also say, "It is better to walk than curse the road". Both proverbs encourage apology by the offender and forgiveness by the victim. Furthermore, the Yoruba people use the following proverb to underscore the necessity of forgiving, "If we chastise a child with the right hand, we should draw them near ourselves with the left" (Bí a bá fi owó òtún bá omo wí, à sì tún fi owó òsì fà á móra) (Adegoju 2009: 
65). In the proverb, the offender who is begging for forgiveness is symbolised as a child being disciplined. The same people also clearly indicate the appropriateness of forgiving the offender after an admission of guilt and an apology. As they say, "If one agrees that one is guilty in a case, then one will not stay long on his knees" (B'elejo ba m'ejoo re lebi, ko nipe lori ikunle) (Kazeem 2010: 6). The social bonds of traditional African societies cannot be easily broken. For this reason, casting a wrongdoer out of his/her community is hardly possible.

Mediators in traditional African societies always believe that their success in their reconciliation efforts is heavily dependent on the Creator. The Creator supports and monitors their conflict resolution endeavours. For example, the Amhara of Ethiopia in this regard say, "Man begins, the Creator completes it" (Sew yasibal fetari yfetsmal). For this reason, they beg Him to be with them in their reconciliation efforts and give credit to Him at the end of a successful reconciliation (Olateju 2013). Mediators persuade disputants that everything is predetermined by the Creator, as the Urhobo from Nigeria say, "The water to be drunk by one from the river always awaits one" (Ame ra da dje waan) (Ohwovoriole 2011: 130). Remedy for every problem is also from the Creator. The Ghanaians believe that "if God breaks your leg, He will teach you how to limp" (Afriprov 2004: 1). The Tigray also believe that "when God creates cliff, along with it, He creates a ladder" (Gedel ya enkifetirs medeyaybo ewun yfetr). In the proverb, social challenge and its possible solution are symbolised by cliff and ladder respectively.

With the above understanding, verdicts of mediators are respected and enforced through the support of their Creator and the social morality of the target community. In principle, every community member has a responsibility to respect and implement the decisions of the mediators. It is believed that someone who breaks consensus may suffer social sanctions and his/her Creator's coercion (Adan \& Pkalya 2006). That is why the Tanzanians from East Africa say, "If you refuse the elder's advice, you will walk the whole day" (Afriprov 2000: 1).

\section{CONCLUSION}

In an effort made to find out contributions of traditional African societies' proverbs in depicting the communities' conflict prevention and conflict management principles through socio-semiotic approach to discourse studies and interpretive analysis, they are found indispensable in portraying peace-keeping and peacemaking values among the communities. For their discourse to have pragmatic force, taste, and precision, communities widely employ proverbs when they prevent and resolve conflicts using their own conflict prevention and conflict 
management principles. Persuading disputants to avoid conflict and to settle their dispute peacefully, preaching communal moral, teaching lessons of good and evil, and explaining the need for and benefit of mutual understanding and peaceful coexistence are among the social goals performed by employing proverbs. If the communities use culture and context sensitive proverbs, they play a vital role in legitimising traditional African society's conflict prevention and conflict management institutions.

Through their proverbs, traditional African societies preach closing space for dispute, avoiding provocation and settlement of disagreement through peaceful discussion and patience. Despite all these efforts, when disputes occur, the communities employ proverbs which encourage taking communal responsibility to address the dispute, following transparent truth-finding procedures, creating forum for participatory negotiation, finding win-win solutions, and aiming at reconciliation and restoration of communal peace and harmony.

If the proverbs are to continue being a source of wisdom for the generations to come, they have to be properly collected, documented, and used where appropriate. Makamani (2013: 11) argues, "Africans should, and can, utilise their own knowledge systems to overcome challenges hence become truly independent and thus experience a developmental boost guided by Ubuntu/Unhu and/or Ujamaa way of life enshrined in African proverbs". Otherwise, as Dore (n.d.), cited in ECA (2007: 11), notes, "When policy neglects history, culture, and social context, huge amounts of effort and resources can be wasted on poorly conceived initiatives".

\section{NOTES}

1 Except for some of the Ethiopian proverbs, proverbs without source are taken from Special Dictionary, available at: http://www.special-dictionary.com/, last accessed on November 27, 2015.

2 Though priority is given to seniors either in terms of age or social status, any matured person who is accepted by disputants and capable of mediation can be a mediator.

\section{REFERENCES}

Abayomi, Onifade 2014. Philosophical Significance of Yoruba Proverbs. Available at http://www.academia.edu/3397082/Philosophical_Significance_of_Yoruba_ Proverbs, last accessed on November 27, 2015.

Adan, Mohamud \& Pkalya, Ruto 2006. Conflict Management in Kenya: Towards Policy and Strategy Formulation. Practical Action (report). Available at http:// practicalaction.org/media/view/6194, last accessed on November 27, 2015. 
Adegoju, Adeyemi 2009. Rhetoric in Conflict-Related Yoruba Proverbs: Guide to Constructive Conflict Resolution in Africa. African Study Monographs, Vol. 30, No. 2, pp. 55-69. Available at http://www.africa.kyoto-u.ac.jp/asm/normal/asm_302.html, last accessed on November 27, 2015.

Adeyemi, Adeniyi Babadunde \& Salawudeen, Olabisi Muijidat 2014. The Place of Indigenous Proverbs in Peace Education in Nigeria: Implications for Social Studies Curriculum. International Journal of Humanities and Social Science, Vol. 4, No. 2, pp. 186-192. Available at http://www.ijhssnet.com/journals/Vol_4_ No_2_Special_Issue_January_2014/18.pdf, last accessed on November 27, 2015.

Afriprov 2000 = African Proverb of the Month. Afriprov.org: African Proverbs, Sayings and Stories. Available at http://www.afriprov.org/index.php/african-proverb-ofthe-month/26-2000proverbs/152-march2000.html, last accessed on November 27, 2015 .

Afriprov 2004 = African Proverb of the Month. Afriprov.org: African Proverbs, Sayings and Stories. Available at http://www.afriprov.org/index.php/african-proverb-ofthe-month/30-2004proverbs/205-sep2004.html, last accessed on November 27, 2015.

Afriprov 2005 = African Proverb of the Month. Afriprov.org: African Proverbs, Sayings and Stories. Available at http://www.afriprov.org/index.php/african-proverbof-the-month/31-2005proverbs/220-patience-can-cook-a-stoneq-fulfulde-beninburkina-faso-cameroon-central-african-republic-chad-mali-niger-nigeria-sudanand-togo-.html, last accessed on November 27, 2015.

Akinmade, Arinola C. 2012. The Decline of Proverbs as a Creative Oral Expression: A Case Study of Proverb Usage among the Ondo in the South-Western Part of Nigeria. AFRREV LALIGENS: An International Journal of Language, Literature and Gender Studies, Vol. 1, No. 2, pp. 127-148. Available at http://afrrevjo.net/ journals/laligens/Vol_1_(2)_art_10.pdf, last accessed on November 27, 2015.

Albert, Isaac Olawale \& Awe, Tinu, \& Hérault, Georges \& Omitoogun, Wuyi 1995. Informal Channels for Conflict Resolution in Ibadan, Nigeria. Ibadan: Institut français de recherche en Afrique.

Ayittey, George B. N. 1991. Indigenous African Institutions. Ardsley-on-Hudson, NY: Transnational Publishers.

Degnew, Tesfaye \& Wodajo, Mesfin 2014. The Socio- Cultural Functions of Kafa Proverbs. African Journal of History and Culture, Vol. 6, No. 6, pp. 94-99. DOI: 10.5897/ AJHC2014.0198.

ECA 2007 = United Nations Economic Commission for Africa. Relevance of African Traditional Institutions of Governance. Available at http://www.uneca.org/search/ node/Relevance\%20of\%20African\%20Traditional\%20Institutions\%20of\%20 Governance, last accessed on December 1, 2015.

Finnegan, Ruth 1970. Oral Literature in Africa. Oxford \& New York: Oxford University Press.

GIZ 2013 = Deutsche Gesellschaft für Internationale Zusammenarbeit. Shimgelina under the Shade: Merging Ethiopian Wise-Counsel Mediation and Facilitative Mediation. A Training Manual. Addis Ababa: Central Printing Press. Available at http://www.ziviler-friedensdienst.org/sites/ziviler-friedensdienst.org/files/anhang/ 
publikation/zfd-merging-ethiopian-wise-counsel-mediation-and-facilitativemediation-1949.pdf, last accessed on November 27, 2015.

Halliday, Michael A. K. \& Hasan, Ruqaiya 1985. Language, Context and Text: Aspects of Language in a Social-Semiotic Perspective. Victoria: Deakin University.

Hussein, Wolyie J. 2009. A Discursive Representation of Women in Sample Proverbs from Ethiopia, Sudan and Kenya. Research in African Literatures, Vol. 40, No. 3, pp. 96-108. http://dx.doi.org/10.2979/RAL.2009.40.3.96.

Kaphagawani, Didier N. 2006 [2004]. African Conceptions of a Person: A Critical Survey. In: K. Wiredu (ed.) A Companion to African Philosophy. Malden, MA: Blackwell, pp. 332-342.

Kazeem, Ademola 2010. The Logic in Yoruba Proverbs. Itupale Online Journal of African Studies, Vol. 2, pp. 1-14. Available at http://www.researchgate. net/publication/259717846_The_Logic_in_Yoruba_Proverbs, last accessed on November 27, 2015.

Kuruk, Paul 2002. African Customary Law and the Protection of Folklore. Copyright Bulletin, Vol. XXXVI, No. 2, pp. 4-32. Available at http://unesdoc.unesco.org/ images/0012/001277/127784e.pdf, last accessed on November 27, 2015.

Makamani, R. 2013. African Proverbs and Conflict Management: A Study of Selected Shona, Oshivambo, Yoruba and Swahili Proverbial Expressions. Available at http://ir.polytechnic.edu.na/bitstream/handle/10628/429/Makamani.\%20African\%20proverbs.pdf;jsessionid=C35036DA2353AA683DC60E0BC12EF03D?se quence=1, last accessed on November 27, 2015.

Malunga, Chiku \& James, Rick 2004. Using African proverbs in organizational capacity building. Praxis Note No. 6. Available at http://www.intrac.org/data/files/ resources/103/Praxis-Note-6-Using-African-Proverbs-in-Organisational-CapacityBuilding.pdf, last accessed on November 27, 2015.

Mandova, Evans \& Wasosa, Wellington 2013. The Role of Proverbs in the Shona Judicial System with Special Reference to Nhango Dzokusuma Nyaya Padare. International Journal of Asian Social Science, Vol. 3, No. 4, pp. 871-877. Available at http://www.aessweb.com/pdf-files/ijass-3(4)-871-877.pdf, last accessed on November 27, 2015.

Moumakwa, Constance 2010. The Botswana Kgotla System: A Mechanism for Traditional Conflict Resolution in Modern Botswana. Case Study of the Kanye Kgotla. Master's Thesis in Philosophy of Peace and Conflict Transformation. Faculty of Humanities, Social Sciences and Education, University of Troms $\emptyset$. Unpublished. Available at munin.uit.no/bitstream/handle/10037/3211/thesis.pdf?sequence=1, last accessed on November 27, 2015.

Nkonya, Ephraim \& Markelova, Helen \& Kato, Edward 2009. Looking beyond the Obvious: Uncovering the Features of Natural Resource Conflicts in Uganda. CAPRi Working Paper No. 95. Available at: www.ifpri.org/sites/default/files/publications/ capriwp95.pdf, last accessed on November 27, 2015.

Obisakin, Lawrence Olufemi 2010. Proverbs in Communication: A Conflict Resolution Perspective. New York: Triumph Publishing.

Ohwovoriole, Felicia 2011. Peacemaking and Proverbs in Urhobo and Yoruba Martial Conflicts: Part 1. African Conflict and Peacebuilding Review, Vol. 1, No. 2, pp. 122-135. Available at https://muse.jhu.edu/journals/african_conflict_and_ peacebuilding_review/toc/acp.1.2.html, last accessed on November 27, 2015. 
Olateju, Animashaun Rofiah 2013. Preserving the Traditional Measures of Preventing Conflict in Africa. Journal of Education Research and Behavioral Sciences, Vol. 12, pp. 232-238. Available at http://www.apexjournal.org/jerbs/archive/2013/Dec/ fulltext/Olateju.pdf, last accessed on November 27, 2015.

Olatunji, Olatunde 1984. Features of Yoruba Oral Poetry. Ibadan: University Press Limited.

Oraegbunam, Ikenga K.E. 2009. The Principles and Practice of Justice in Traditional Igbo Jurisprudence. Available at www.ajol.info/index.php/og/article/viewFile/52335/40960, last accessed on November 27, 2015.

Phillips, Foluso 2011. Peacemaking and Proverbs in Urhobo and Yoruba Martial Conflicts: Part 2. African Conflict \& Peacebuilding Review, Vol. 1, No. 2, pp. 136-152. Available at https://muse.jhu.edu/journals/african_conflict_and_peacebuilding_ review/toc/acp.1.2.html, last accessed on November 27, 2015.

Porter, Terry B. 2005. Identity Subtexts in the Discursive Construction of Sustainability. Available at http://www.mngt.waikato.ac.nz/ejrot/Vol9_1/Porter.pdf, last accessed on November 27, 2015.

Renkema, Jan 2004. Introduction to Discourse Studies. Amsterdam: John Benjamins Publishing.

Special Dictionary. Proverbs. Available at http://www.special-dictionary.com/proverbs/, last accessed on November 27, 2015.

UN 2004 = United Nations Security Council. The Rule of Law and Transitional Justice in Conflict and Post-Conflict Societies: Report of the Secretary-General, S / 2004 / 616, 23 August. Available at www.unrol.org/files/2004\%20report.pdf, last accessed on November 28, 2015.

Wojkowska, Ewa 2006. Doing Justice: How Informal Justice Systems Can Contribute. United Nations Development Programme, Oslo Governance Centre. Available at http://siteresources.worldbank.org/INTLAWJUSTINST/Resources/EwaWojkowska. pdf, last accessed on November 28, 2015.

Yankah, Kwesi 2012 [1985]. The Proverb in the Context of Akan Rhetoric. New York: Diasporic Africa Press.

Yitah, Helen 2006. Throwing Stones in Jest: Kasena Women's "Proverbial" Revolt. Oral Tradition, Vol. 21, No. 2, pp. 233-249. Available at http://journal.oraltradition. org/issues/21ii/yitah, last accessed on November 28, 2015. 


\title{
SCIENTIFIC CONTACTS WITHIN ETHNOLOGY AND FOLKLORISTICS BETWEEN SWEDEN AND ESTONIA
}

\section{Personal Experiences and Considerations}

\author{
Anders Gustavsson
}

In recent years, presentations of scholars' subjective experiences and reflections have been an object of increasing interest in Nordic ethnology and folkloristics (Hellspong \& Skott 2010; Rogan \& Eriksen 2013). In this survey I will present a self-reflective overview of my experiences with new research contacts that became possible beginning in 1991, after the Baltic States - Estonia, Latvia, and Lithuania - had been in isolation for decades. Although after 1991 ethnological views in Sweden focused on all the three Baltic countries, the focus here will be on Estonia as ethnologists at Uppsala University had the most contacts with this country throughout the 1990s. I held a professorship at Uppsala University between 1987 and 1997.

During my childhood and youth in western Sweden in the 1940s and 1950s, I did not hear much about the Baltic States. Sweden's deportation of 146 Balts to the USSR in 1946 was the most well-known episode and one that also proved tragic for Sweden (Ekholm 1984). In 1958, a farmer's family moved from the Kalmar district in eastern Sweden to the farm next to the one where I grew up in western Sweden. The farmer's wife told our family about her Swedish/ Estonian background and her former life in Estonia. When she was eleven years of age, she and her family experienced a dramatic escape by boat as refugees from the Estonian island of Ormsö (Vormsi) to Sweden. This was just after the second Soviet invasion of Estonia in 1944.

In 1966, I began my studies of ethnology at the University of Lund. Among my first contacts at the Folklife Archives was an elderly librarian who was known as The Rector. He was said to have been a rector in Estonia before fleeing to Sweden. He was a conscientious person who kept a close eye on the students' loans of books (see Frykman 1988: 92). Other than that, I heard nothing about 
the Baltic States during my basic instruction in ethnology or during the period of post-graduate studies that preceded my doctorate in 1972. When I was appointed as associate professor in ethnology at Lund in the 1970s, I did hear about Gustav Ränk (1902-1998) who worked on the ethnology of food. He had been the first holder of the professorship of ethnology at Tartu University in the years 1939-1944. When the professorship was abolished, he fled to Sweden. During the Soviet period ethnological research in Estonia existed under the label of ethnography (Annist \& Kaaristo 2013). In 1947, the Chair of Folklore at Tartu (State) University was united with the Department of Literature. Within the available courses, the possibility to specialise in folklore remained (see http://www.ut.ee/folk/index.php/en/department/history).

Ränk became a well-known and respected ethnologist in Stockholm (Hellspong 1993: 10). The later appointed professor of ethnology at Tartu University, Elle Vunder (see below), was overjoyed at being able to meet him in Stockholm after 1991. This enabled her to interview him about his life in Estonia. In the 1970s, I became acquainted with Ilmar Talve (1919-2007). He had graduated in 1942, after completing studies in ethnology in Tartu, but had later fled to Sweden through Germany. In Stockholm he continued his studies in ethnography and in 1960 he defended his doctoral thesis about sauna and drying houses in Northern Europe. I heard him speak about his background in Estonia. In 1962, he was appointed professor of ethnology at the Finnish University in Turku, Turun Yliopisto, where he worked until 1986. His research concentrated on the folk culture of Finland. He also wrote a wide-ranging work on the cultural history of Estonia, which was published in 2004 (Talve 2004: 101ff.; Elmevik 2007: 14f.).

During the summer of 1980, I participated in fieldwork focused on culture in the coastal region of south-eastern Finland together with colleaguesethnologists from Helsinki. This was the time when I learned how Finnish scholars established contacts with Estonia by sea. A colleague of mine, folklorist Leea Virtanen, had just returned from a boat trip to Tallinn.

It was only when the Baltic Sea seminars under the name Kolloquium Balticum Ethnographicum were resumed in 1984 in Schwerin, East Germany, after having been discontinued since 1966, that I came into contact with scholars from the Baltic States. They were able to travel freely behind the Iron Curtain but were absolutely forbidden to travel farther west. During a later conference in Stralsund, East Germany, in 1987, plans were made to hold the next conference in Riga, Latvia. Scholars from Latvia expressed grave doubts about whether their Nordic colleagues would be able to get entry permits to the Baltic States. These doubts were based on the intense Soviet rearmament at the time and their deployment of missiles quite near to Sweden. Thanks to the political 
liberalisation that occurred under the leadership of Mikhail Gorbachev after 1987, this conference could be held in late April, 1990. Several Nordic delegates participated and even one from West Germany. That would have been completely impossible in earlier years.

In Riga I became acquainted with Elle Vunder, who presented a paper on German influences on Estonian folk art (Vunder 1993: 142ff.). My own paper concerned a study of the Forest Finns who had emigrated from Finland in the 1500s and 1600s to the border districts of Norway/Sweden (see below) (Gustavsson 1993: 24f.). While we were in Riga, we became very aware of the obvious political unease because of a Latvian parliamentary election scheduled only a few days later in early May. Domestic Soviet troops from Moscow, called the black berets, were posted in the streets. The Letts themselves had no idea about what the future would hold. We Nordic delegates were extremely relieved at being able to leave Riga on 30 April. We later followed news reports of events that took place in connection with the election with great interest.

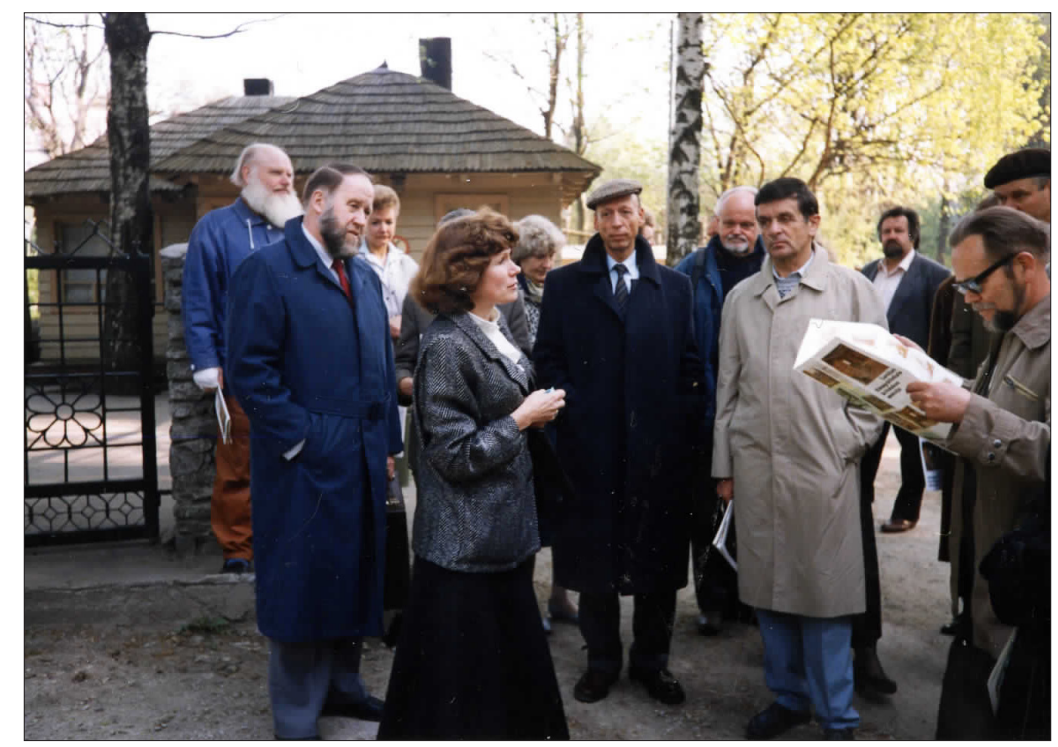

Figure 1. A conference held by Kolloquium Balticum Ethnographicum in Riga, Latvia, in 1990. The man in the middle wearing a dark coat and a cap is Kai Detlev Sievers from Kiel, West Germany. Standing to his right and wearing a light coat is Hermann Strobach from East Berlin. To the extreme left of the first row is Nils Storå from the Abo Akademi, Finland. Photograph by Anders Gustavsson. 
Having had these experiences in Riga, I took great interest in attending the so-called Monday Movement meetings held in the Main Square in Uppsala throughout 1990 and 1991. The purpose of these meetings, which were arranged in a great many Swedish towns, was to demonstrate solidarity with the Baltic States' attempts to liberate themselves from the USSR (see https://sv.wikipedia. org/wiki/Måndagsrörelsen). Andres Küng and some well-known Swedish politicians, such as Carl Bildt, came to Uppsala where they spoke to large crowds of people at noon, Monday after Monday. As early as 1989, another colleague, Professor Juha Pentikäinen from Helsinki, visited Uppsala. There he spoke about his personal experiences in Tallinn, recalling the mass demonstrations that had taken place since 1987, featuring spontaneous singing of national songs and hymns. These events, called the Singing Revolution, finally led to the restoration of independence in Estonia in 1991 (Thomson 1991; Smidchens 2014).

The first Nordic project I participated in together with an Estonian was the so-called Finnforest project (Gustavsson 1987, 1989, 1993), which lasted from 1986 to 1990. Project participants met each year to conduct fieldwork among the descendants of the Finns who had migrated from Savolax in central Finland to the border districts of Norway and Sweden in the 1500s and 1600s. Our studies concentrated on northern Värmland County in Sweden and Hedmark County in Norway. Thanks to Finnish contacts with Estonia, Toivo Sikka from the Estonian National Museum in Tartu was granted permission to travel and participate in these fieldwork studies. This also provided Nordic scholars with an opportunity to understand the difficult research conditions in Estonia. As Norwegian folklorist Stein R. Mathisen wrote in a report of one fieldwork session, "the participants showed great interest in the possibility of collaborating with Estonia" (Mathisen 1990: 147).

Closer contacts with Estonian researchers, research students, and museum professionals became possible only after 1991. By that time ethnologists in Uppsala had realised the importance of setting up cooperative projects with the newly independent Baltic States. This began with Estonia and continued with Latvia and Lithuania. Students and researchers from the Baltic States could be invited to come to Uppsala. The younger generation had an obvious longing for contacts with the West and, geographically speaking, Sweden lay closest to hand. Several students learned Swedish for the purpose of being able to read Swedish literature and to acquire personal contacts in Scandinavia.

The Swedish/Estonian records in the Dialect and Folklore Archives in Uppsala (Dialekt- och Folkminnesarkivet, abbreviated DUF, formerly ULMA) proved to be of special interest to Estonian researchers. This material had been collected in Estonia in the interwar years and also among the Swedish/Estonian refugees who had come to Sweden during the final phases of World War II. The 


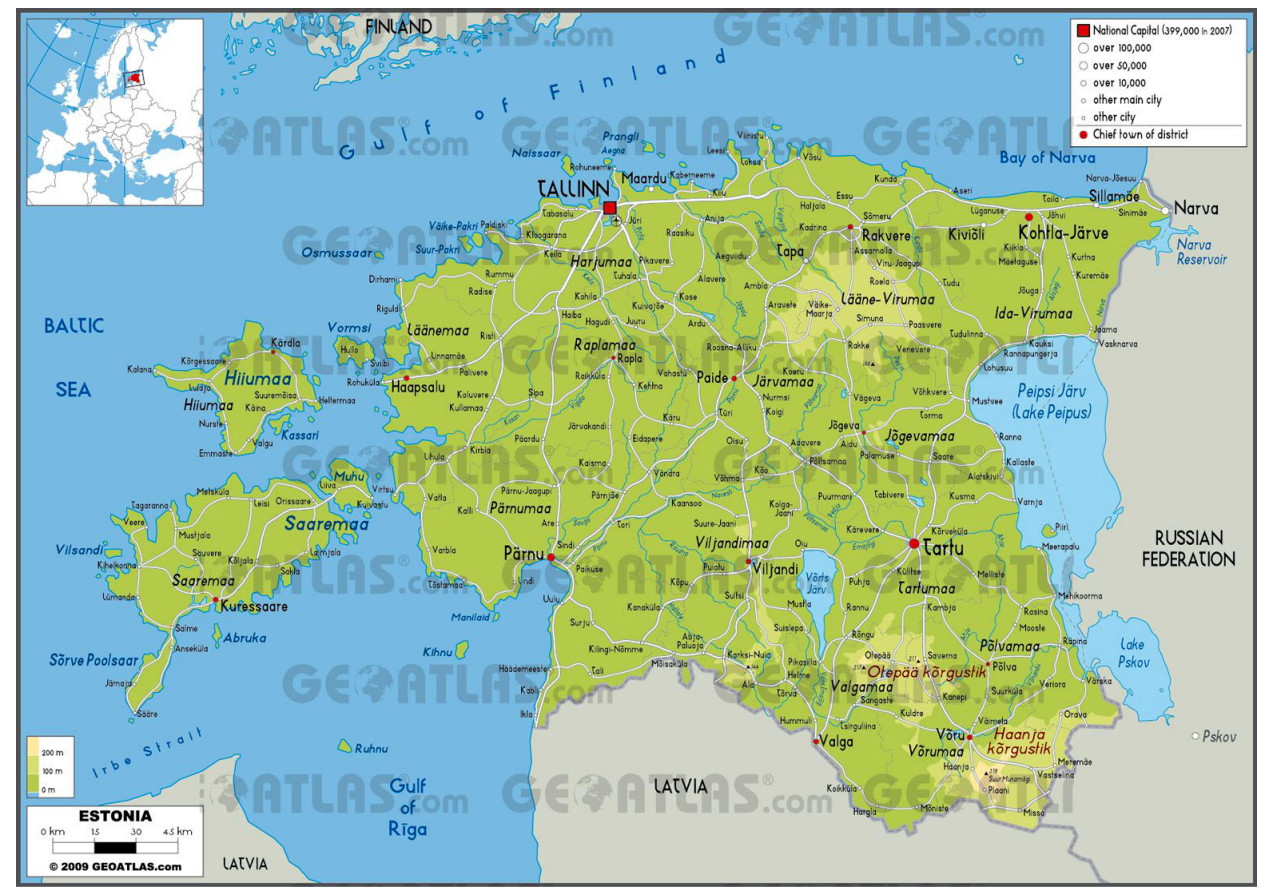

Figure 2. Map of Estonia after regaining independence in 1991 (http:/ / www.geoatlas.com/en/maps/countries-4/estonia-1165).

most important collector of material on both language and folk culture was Nils Tiberg (1900-1980) (see www.sprakochfolkminnen.se/folkminnen/samlingar/ estlandssvenska-samlingar.html). During the early 1990s, head archivist Wolter Ehn became the central person regarding contacts with Estonia. The Swedishspeaking historian and ethnologist Juta Holst from the Estonian Open Air Museum at Rocca al Mare, Tallinn, established in 1957 (http://evm.ee/eng/home), spent several periods as a guest researcher at the archives in Uppsala. Here she studied the Swedish/Estonian material that had been collected in Sweden. Her research interests focused on Swedish/Estonian agriculture during the interwar years. As a professor at the Institute of Ethnology at Uppsala, I was involved in the contacts with Juta Holst. Elle Vunder also came to Uppsala as a guest researcher and visited our home at the time.

In my capacity as professor, I took part in arranging three Nordic research courses in Uppsala in the early 1990s. At the time, the Nordic Research Training Academy (Nordisk forskerutdanningsakademi (NorFA)) had made funds available to participants from the Baltic States. This gave several Estonian 


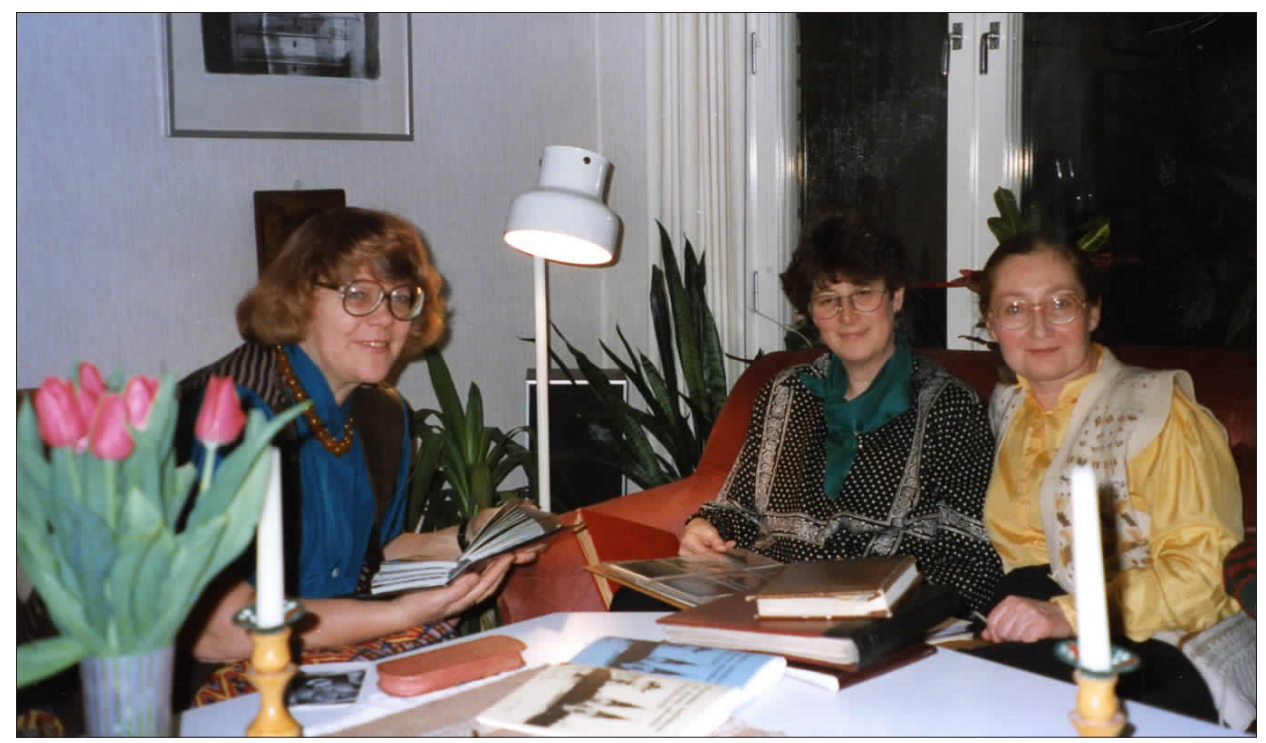

Figure 3. Elle Vunder from Tartu (on the left) with Juta Holst from Tallinn (on the right) on a visit to the author's home in Uppsala in 1992. Between them the author's wife, Kristina. Photograph by Anders Gustavsson.

research students an opportunity to come to Uppsala. Several of them had learned Swedish. Some of the discussions were held in English to accommodate participants not only from the Baltic States but also from Finland. The importance of these research courses is apparent in the evaluations later made by the Baltic participants. One of them from Tallinn wrote after completing a research course in 1991:

I think that the opportunity to participate in such research courses is extremely important, especially for the Baltic States and their futures because we have not had such contacts earlier (in the years after 1940) and information about studies in the humanities has been obstructed. (Gustavsson 1992: 9)

Nordic cooperation with the Baltic States was also launched on the student level. In 1992, the Institute of Ethnology at Uppsala was visited by two lecturers and six students from Tartu University. This was in response to an invitation from the Uppsala section of the Nordic Ethnological and Folkloristic Working Group (NEFA). NEFA Uppsala made a return visit in the spring of 1993. NEFA publishes the journal Nord Nytt: Nordisk tidsskrift for etnologi og folkloristik (Nordic News: The Nordic Journal of Ethnology and Folkloristics). A theme 
issue, Estnisk etnologi (Estonian Ethnology), published in 1994, included articles by Estonian scholars written either in Swedish or in Estonian and translated into Swedish. As a graduate student, Liisa Pakosta at Tartu University wrote in the preface to this theme issue:

We hope that this little contribution is representative for a country on the Baltic Sea that has long been disregarded. Much has taken place in Scandinavia during the past fifty years. One element in this development is the nearly total break in contacts between the Baltic States and the Nordic countries. [---] It is to be hoped that this issue of Nord Nytt can also serve as a cultural and scientific link that can contribute to the integration of Scandinavia and the Baltic States into a single cultural area. (Pakosta 1994: 3)

In connection with a Nordic research network on the topic of Alcohol and Abstinence, I arranged three symposia in Uppsala in the years 1989, 1991, and 1993. Younger scholars from the Baltic States were able to attend the final gathering of the network thanks to special funds set aside for this purpose by the Nordic Research Training Academy NorFA (Gustavsson 1994: 8f.). The Balts were increasingly included in Nordic education and research cooperation in the years following 1991.

Contacts with Estonian scholars led to invitations to scholars and students at the Institute of Ethnology in Uppsala and to the personnel at ULMA/DUF. An excursion to Estonia took place between May 3 and 7, 1993. The guides were Juta Holst and Elle Vunder in Tallinn and Tartu respectively. We were able to visit the Swedish/Estonian coastal districts that had had a Swedish-speaking population as early as the $1200 \mathrm{~s}$. We also inspected the ruins of secret Soviet radio interceptions and radar installations. These were used to spy on Western activities in the Baltic Sea and on Swedish radio transmissions. No Estonians were allowed to come near these sites until after the Soviet withdrawal in the autumn of 1992, half a year before our visit. Before their withdrawal, they had destroyed military buildings and even burned large areas of nearby forests. Some islands were completely ruined because of all the abandoned military debris. We were also told of how Estonians were not permitted to use the best beaches near Tallinn during the Soviet occupation. These had been reserved for the Soviet troops. It was even thought that many of the fires that had broken out at the buildings in the Open Air Museum at Rocca al Mare had been started for political reasons.

We met some elderly women from the coastal districts who were still able to speak Swedish despite the fact that this language had not been taught during the Soviet occupation. They told us about the Soviet defence systems on the 


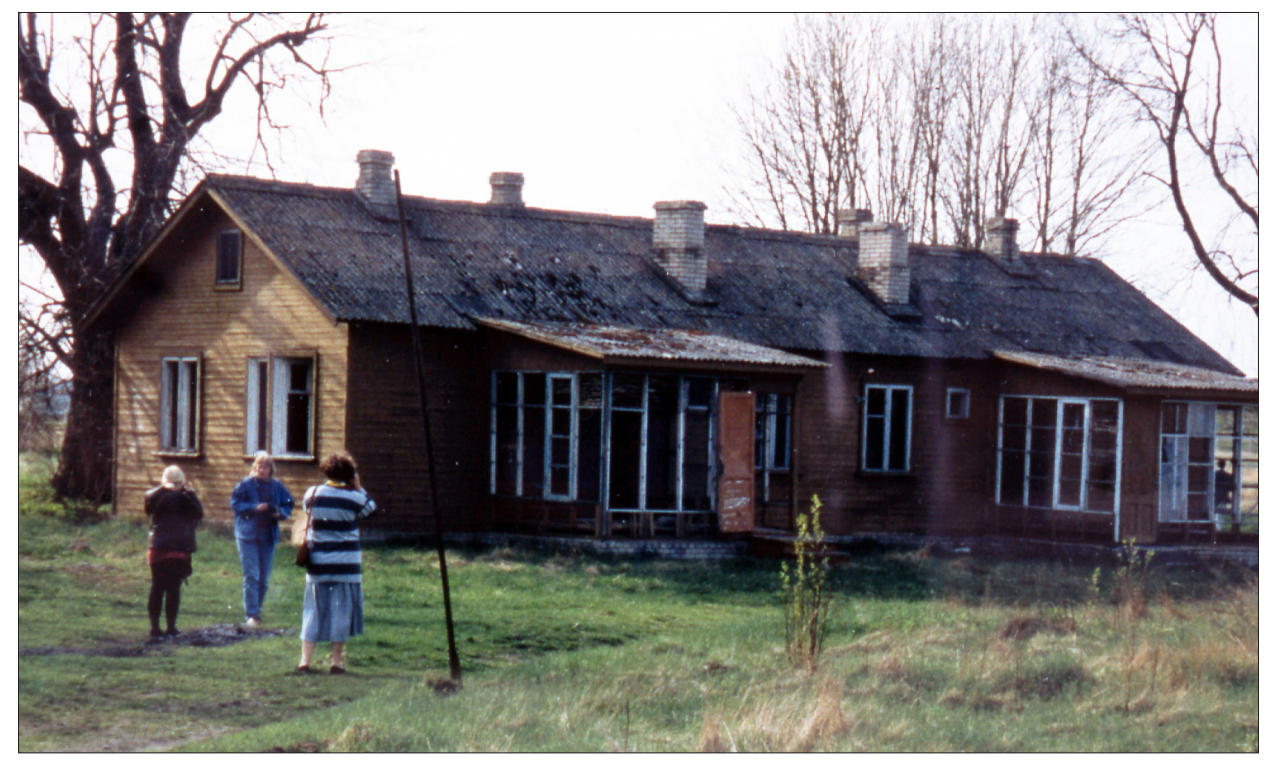

Figure 4. A military building in western Estonia whose windows and inventories were destroyed by the Soviet troops before they left the district in 1992. Photograph by Kristina Gustavsson 1993.

islands along the western coast of Estonia. Local Swedish/Estonian inhabitants were deported during the last phases of World War II. An amateur artist, Felix Georg Sedman, who had lived his entire life on Nuckö (Noarootsi), told us in Swedish about his confirmation in 1936, led by Sven Danell, the future Swedish bishop of Skara diocese. This storyteller remembered the deportation of Estonians to Siberia in both 1941 and 1949. Soldiers had driven up in trucks at dawn and taken nearly all the local people, both young and old. Very few deportees ever returned to their home village. Sedman had escaped, however. His later attempt to escape to Sweden failed and led to his imprisonment. The excursion participants felt the terrible history of this Swedish neighbouring region as having occurred uncomfortably close by.

When we later visited Tartu during our excursion, the story of how the Swedish King Gustav II Adolf had founded the university in 1632 was told with great pride. A small statue of this king set up in commemoration of the founding was not allowed to remain by the Soviet occupation forces and was removed and destroyed. In connection with the Singing Revolution, the people of Tartu built a statue of snow representing Gustav II Adolf. A completely new and permanent statue was erected after Estonia had regained independence in 1991. 


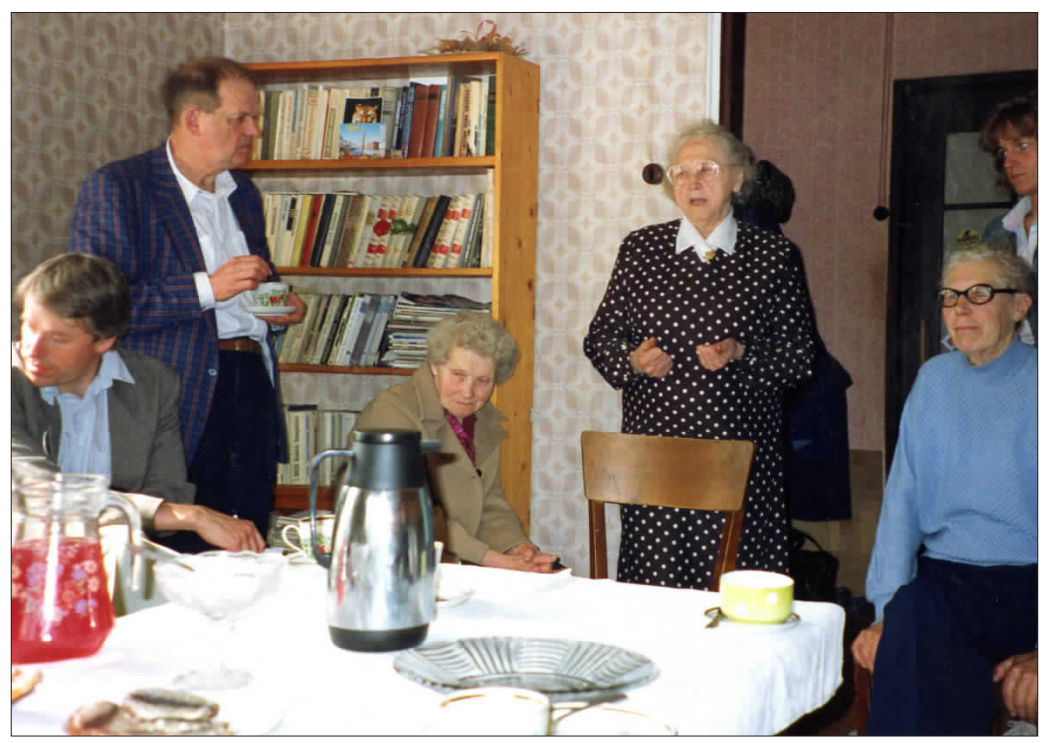

Figure 5. Ethnologist Wolter Ehn standing on the left is listening to three elderly Swedish /Estonian women who relate in Swedish about the circumstances of their lives. The woman standing in the centre is Vilhelmine Sandvik who invited us for coffee in her home. Photograph by Kristina Gustavsson 1993.

Ants Viires (1918-2015) was the only one of the ethnologists trained before the war who still lived in Estonia. At the time of our visit in 1993 it was felt to be of prime importance that new ethnologists and folklorists could be trained as quickly as possible. These were some of the students who visited Uppsala during their study tours. Some of these newly educated scholars were appointed to leading positions at universities and museums at a very young age since no older candidates were available. Jaanus Plaat became director of the Estonian National Museum in Tartu, founded in 1909, at the age of thirty. Ülo Valk (born in 1962) became professor of folkloristics in Tartu at the same age in 1994. He specialised in the field of worldwide concepts of the devil. Elle Vunder (born in 1939) became professor of ethnology in Tartu in 1994 at the age of fifty-five. Ten years later she was honoured with a Festschrift emphasising her scientific achievements. I was among the nine Nordic scholars who contributed articles to the publication. These marked the contacts of Estonian ethnology with Scandinavia under Elle Vunder's leadership (Kõresaar \& Leete 2004). My contribution concerned ritual commemorations of sudden death in times past and present (Gustavsson 2004). 
The cooperative efforts between Uppsala and Estonia were tragically interrupted when Wolter Ehn and two of his ULMA-colleagues perished in the Estonia shipwreck on 28 September 1994. Wolter Ehn's wife Marianne was one of the last to be rescued from the sea. These ULMA-colleagues were travelling to follow up the contacts with Estonian scholars and museum personnel, which had been inaugurated during the previous year's excursion. I will never forget the memorial service that was held when the coffins holding the victims from Uppsala were returned and placed outside Uppsala Cathedral.

The next exchange visit to Tartu was the one carried out by me and research assistant Jimi Axelsson from Uppsala on 9-14 March 1996. Axelsson was a very active participant in the NEFA Swedish/Estonian cooperative projects. We visited the Estonian National Museum in Tartu, accompanied by a younger scholar named Anu Järs. She had attended a Nordic conference in Uppsala on alcohol and abstinence in 1993. We also studied the immense collections in the folklore archives that had been established in 1927 and since 1940 had been preserved at the Estonian Literary Museum in Tartu. We had the pleasure of attending a disputation in ethnology held for one of the young scholars, Ene Kõresaar. Her thesis on woven textiles considered in a semiotic perspective had

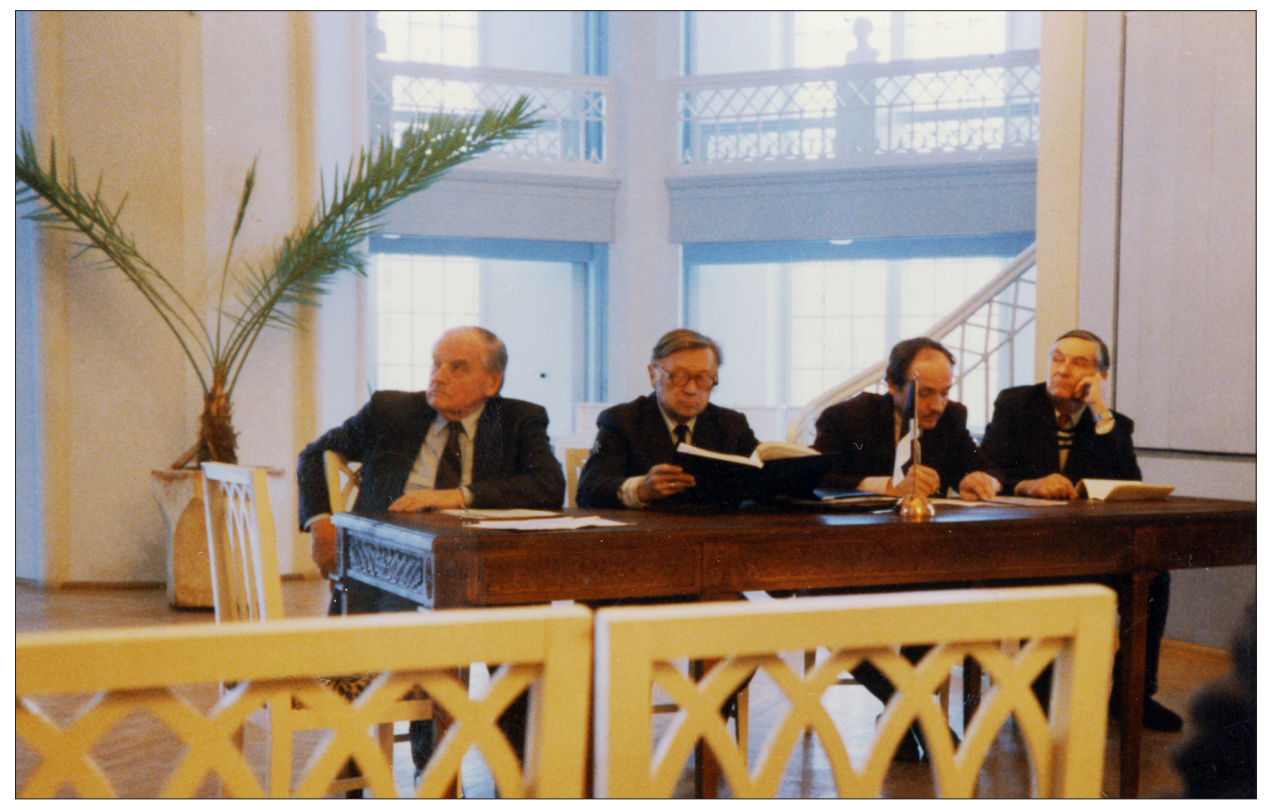

Figure 6. The evaluation board for Ene Kõresaar's thesis. Ants Viires, the first opponent, is on the far left. Photograph by Anders Gustavsson 1996. 
Ants Viires as the first opponent. Thanks to simultaneous interpretation into English, I was able to understand the entire disputation. Afterwards Viires expressed his strong belief that young students and scholars had far more interest in theory than in empirical evidence. This led to ethnologists' losing the more widespread group of readers they had once had in Estonia.

One highlight of the visit to Tallinn in 1996 was visiting Ants Viires at his home together with Juta Holst and Elle Vunder. He had been trained as an ethnologist in Tartu before World War II and had remained in Estonia during the entire period of the Soviet occupation. His ethnological activities were strictly curtailed and restricted during this period. He refused to join the communist party. He had no possibility of taking an examination in ethnology but in 1979 he was allowed to present a doctoral dissertation in history in Moscow. This dealt with popular forms of transportation in the Baltic States. Despite all these difficulties, he was greatly respected in Scandinavia. He was created an honorary doctor at the University of Helsinki in 1982 and an honorary member of the Royal Gustav Adolf Academy for Swedish Folk Culture in 1984.

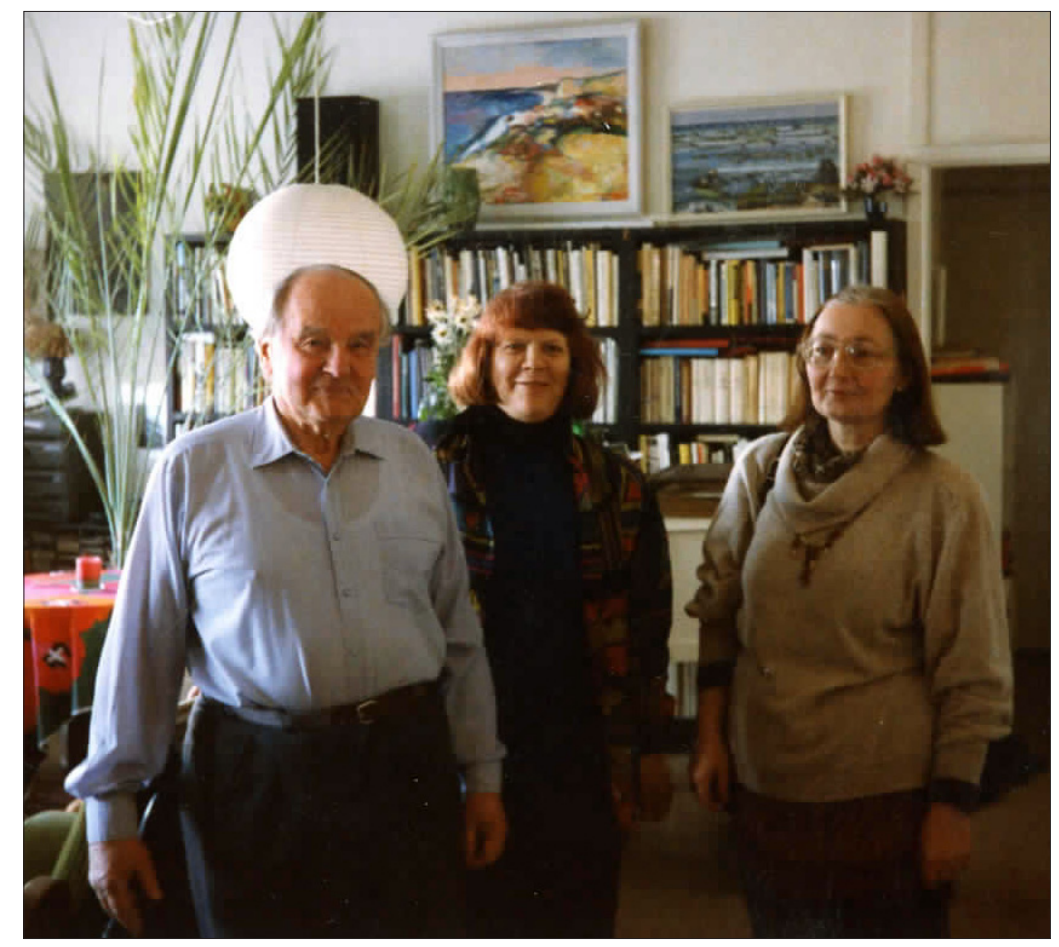

Figure 7. Visiting Ants Viires's home in Tallinn in 1996 with Elle Vunder (in the middle) and Juta Holst (on the right). Photograph by Anders Gustavsson. 
After 1991, Ants Viires held lectures on ethnology in Tallinn, based at the Institute of History. When he was nearly eighty years of age, he published a standard work on Estonian folk culture (Anepaio \& Jürgenson 1998a: 12ff.). For this work he was awarded a medal for meritorious service from the Estonian president, Lennart Meri. On his eightieth birthday, 23 December 1998, he was honoured with a Festschrift to which I and ten other Nordic scholars contributed (Anepaio \& Jürgenson 1998b). My contribution dealt with how both oral narratives and silence are related to the power structure of the surrounding community on either the local or the national level (Gustavsson 1998).

It was also a great pleasure to be present at the re-opening of the Institute of Folkloristics in Tartu in 1996. The professorship in folkloristics had been established in 1920. Throughout the entire interwar period, until 1939, it had been held by folklore scholar Walter Andersson (see www.ut.ee/folk/index.php/ en/department/history). In a report written after a study tour in Estonia in 1996, I noted "the go-ahead spirit and international outlook of the new generation of students and researchers. [---] It is no longer Scandinavia and Sweden that are of prime interest to young Estonians; it is the whole world. The young people are curious to discover not just about the present but also the past. Their increased interest in theoretical awareness is highly palpable" (Gustavsson 1996: 8f.).

The younger scholars' progress since the previous visit in 1993 was, in other words, very obvious. As now the entire world and not only Scandinavia was the focus of their interest, English became the language they wished to learn. Now they tried to take their study and research trips in English-speaking countries. Thanks to their knowledge of the English language, Estonian scholars were able to participate in international conferences arranged by the Societé Internationale d'Ethnologie et de Folklore (International Society for Ethnology and Folklore - SIEF), and the International Society for Folk Narrative Research (ISFNR). In 1996, Jaanus Plaat took part in a conference in Portugal, arranged by me and Maria Santa Montez from Lisbon, under the auspices of the SIEF Working Group on Folk Religion. He presented a paper on religious revival movements in the western regions of Estonia during the period lasting from the mid-1800s to the outbreak of World War II (Plaat 1999).

Ethnologists and folklorists in Tartu even began to publish journals. The first one, Pro Ethnologia, was published by the Estonian National Museum between 1993 and 2005. All articles published in it were written in both Estonian and English in order to attract interest abroad. In 1996, folklorists started Folklore: Electronic Journal of Folklore, which has published 61 volumes so far (see www. folklore.ee/folklore/); Mare Kõiva and Andres Kuperjanov have been editors during the entire period. It is remarkable that Tartu folklorists so quickly published a journal in both printed and digital form. This was many years before 


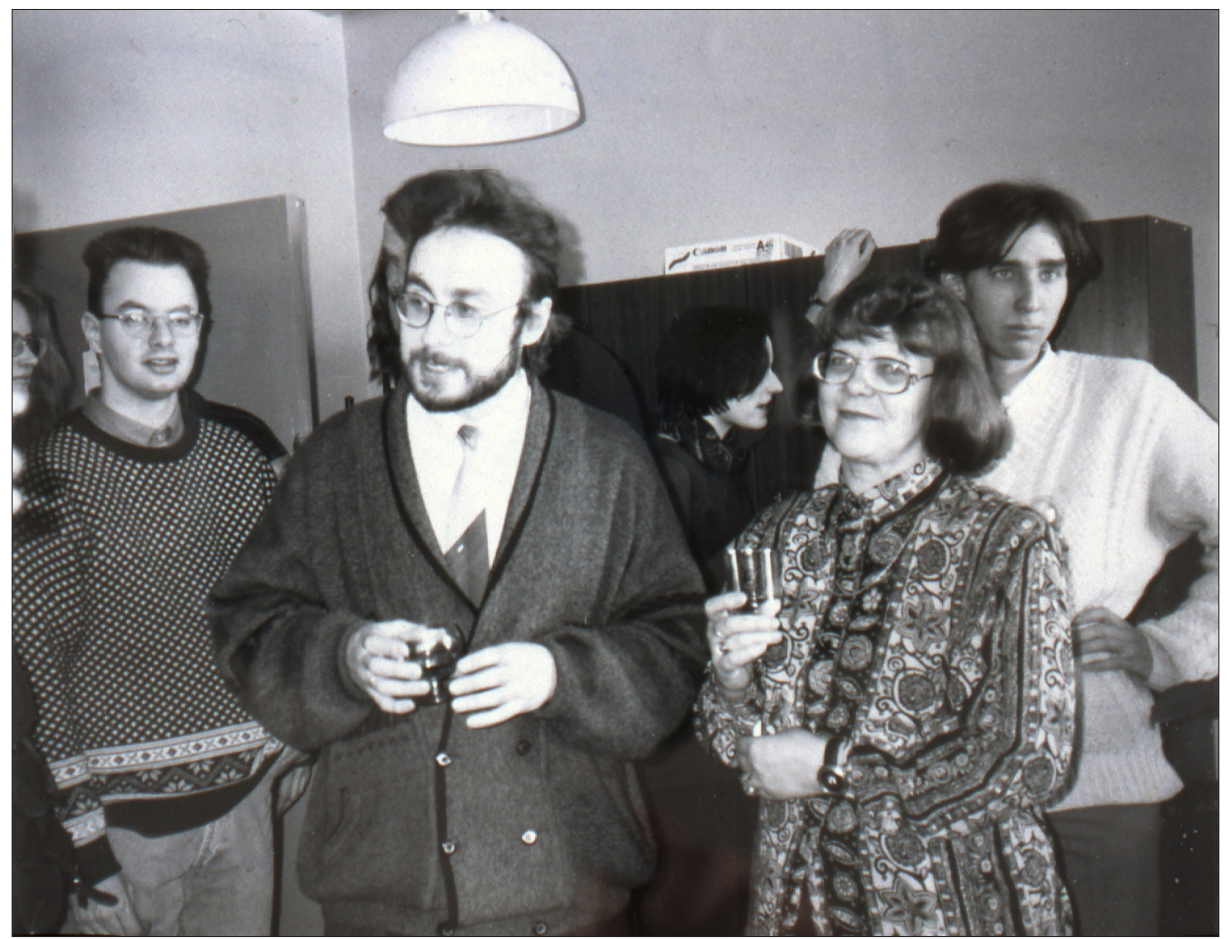

Figure 8. The re-opening of the Institute of Folkloristics in Tartu in 1996. Standing in the foreground (from the left) are Jimi Axelsson, Ülo Valk, and Elle Vunder. Photograph by Anders Gustavsson.

similar attempts were made in Nordic folkloristics and ethnology. I have had the pleasure of publishing three peer-reviewed articles on the topic of death in this journal. They have aroused a great deal of international interest. The next digital journal to be published by the University of Tartu, the Journal of Ethnology and Folklore, appeared in 2007. Two issues are published annually, and scientific papers are accepted from the entire world.

Folklorists in all three Baltic States established The Baltic Institute of Folklore and Folkloristics (BIF) in 1995. It has published the Journal of the Baltic Institute of Folklore and the BIF Newsletter. Its goal has been to coordinate and inform about Baltic folklore research on an international level (see www. folklore.ee/BIF/).

Folklorists in Tartu have also been engaged in international activities through the International Society for Folk Narrative Research, ISFNR. The decision made by the ISFNR, whose members come from eighty countries, to 
hold its 14 th congress in Tartu on 26-31 July, 2005, was a major achievement for the University of Tartu. The theme of the 2005 congress was Folk Narrative Theories and Contemporary Practices. More than two hundred delegates from all over the world attended the congress. The occasion gave me an excellent opportunity to grasp the enormous progress made in Estonian folkloristics after the country had regained independence in 1991, and the international contact network that had been built up. This had been the precondition for holding the world congress there. Mare Kõiva and Ülo Valk played a major role in planning and administering the congress. Ülo Valk was elected president for the period 2005-2009. He also became editor-in-chief of the newly founded ISFNR Newsletter, a position he still holds today (see http://www.isfnr.org/index2.html).

In connection with this conference I was also able to carry out fieldwork accompanied by an Estonian interpreter. The topic of my study was the renewal of religious ceremonies and rituals concerning death among the Orthodox Finno-Ugric Seto people in south-eastern Estonia. They lived on both sides of the Russian/Estonian border and experienced many difficulties when the border became strictly regulated and more difficult to cross after Estonia had regained independence in 1991. Until World War II, the south-eastern border of Estonia had held a more easterly direction towards Russia to the south of the long and narrow Lake Peipsi. During the Soviet occupation the border was drawn more towards the west and divided the Seto people's core area into two. The important town of Petseri (Pechory) ended up on the Russian side. The Seto people have preserved ancient folk costumes and song traditions, which we were able to see and study closely.

An earlier tradition concerning the use of cemeteries as assembly areas for religious ceremonies and meals has been resurrected and intensified after independence was regained in 1991. This was something I experienced on an important religious holiday, Päätnitsapäev (St. Paraskeva's memorial day), in the village of Saatse near the Russian border. Both younger and older relatives of the deceased had set up tables laid with food on many graves. Food and drink, especially vodka but also soft drinks, were available. It was very obvious that this was a festive occasion for the surviving relatives. At the same time they experienced a feeling of solidarity with the deceased. Priests taking part in the meals conversed with me in German. The participants also displayed an evident hospitality to strangers. Not being aware of the cultural codes, I first had much more interest in documentation, conversation, and taking photographs than in eating and drinking. Both the priests and my interpreter insisted on my accepting whatever I was offered. Non-acceptance of this hospitality would have been seen as an insult to both the living and the dead. 


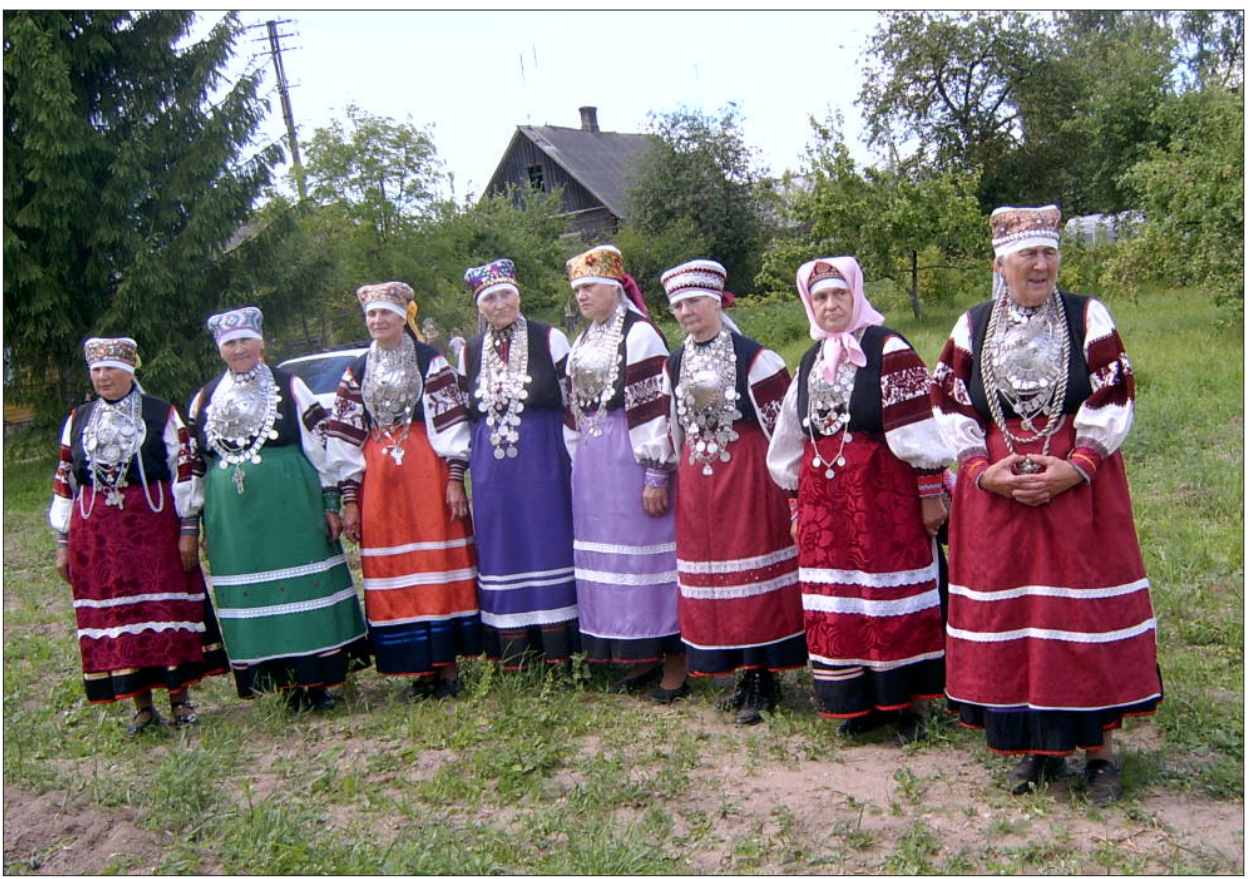

Figure 9. Eight elderly Setu women dressed in traditional folk costumes present folk songs. Photograph by Anders Gustausson 2005.

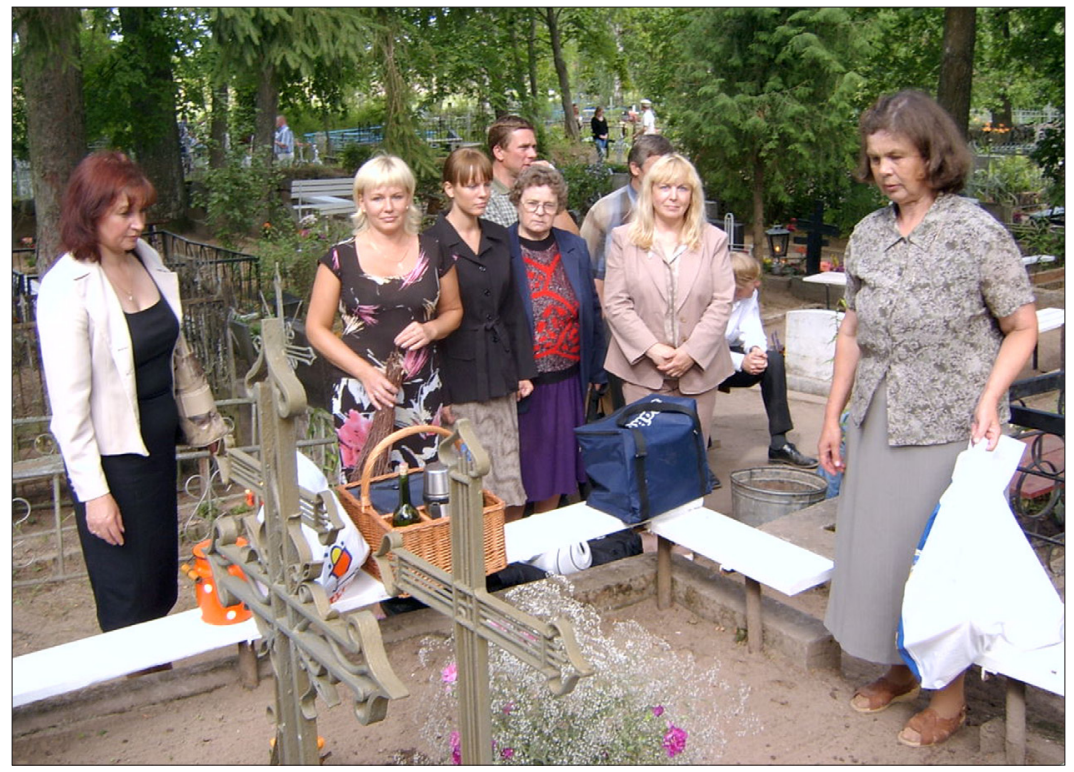

Figure 10. Relatives have arranged a meal on the grave of a deceased in Saatse, Estonia. Photograph by Anders Gustavsson 2005. 
The next occasion on which ethnologists and folklorists in Tartu were asked to arrange a large international congress was on 1-5 July 2013. This was the eleventh congress of the SIEF. Approximately five hundred delegates from over forty countries participated. Chief responsibility for this well-arranged congress lay with Kristin Kuutma (see www.siefhome.org/congresses/sief2013/ index.shtml). Topics in the field of cultural heritage, one of her main fields of interest, played a major role at the congress. Kuutma started as and still is the leader of the SIEF Working Group on Cultural Heritage and Property. I have found this group's activities to be of great benefit in my studies on the choice and conservation of cultural heritage in the form of grave memorials in Swedish cemeteries (Gustavsson 2014b).

The theme for the congress, Circulation, could be interpreted both in an abstract and a tangible sense. I chose a panel having a tangible emphasis, titled Cycling: Past, Present, and Future. My paper presented the earliest history of cycling in Norway and Sweden (Gustavsson 2014a).

The Baltic States received double attention during the summer of 2013 in that the ISFNR also arranged its sixteenth international congress in Vilnius, Lithuania. It was held during the week before the congress in Tartu. The theme was Folk Narrative in the Modern World: Unity and Diversity. One positive feature of this coordination was that it allowed foreign delegates from distant

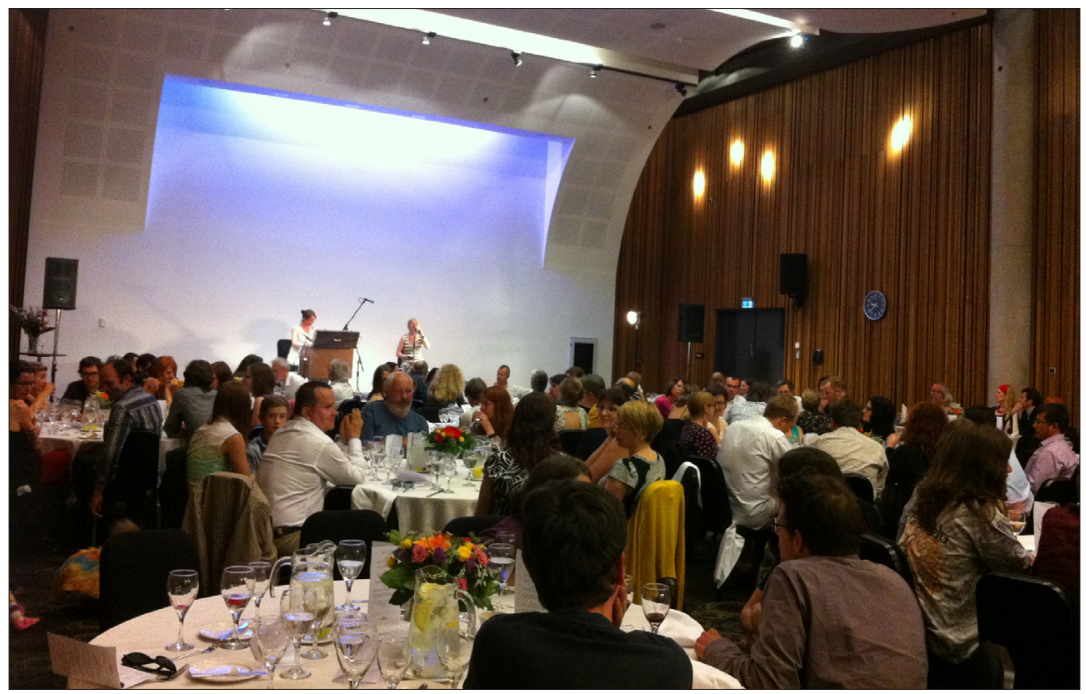

Figure 11. The final dinner marking the end of the SIEF congress in Tartu in 2013. Photograph by Kristina Gustavsson. 


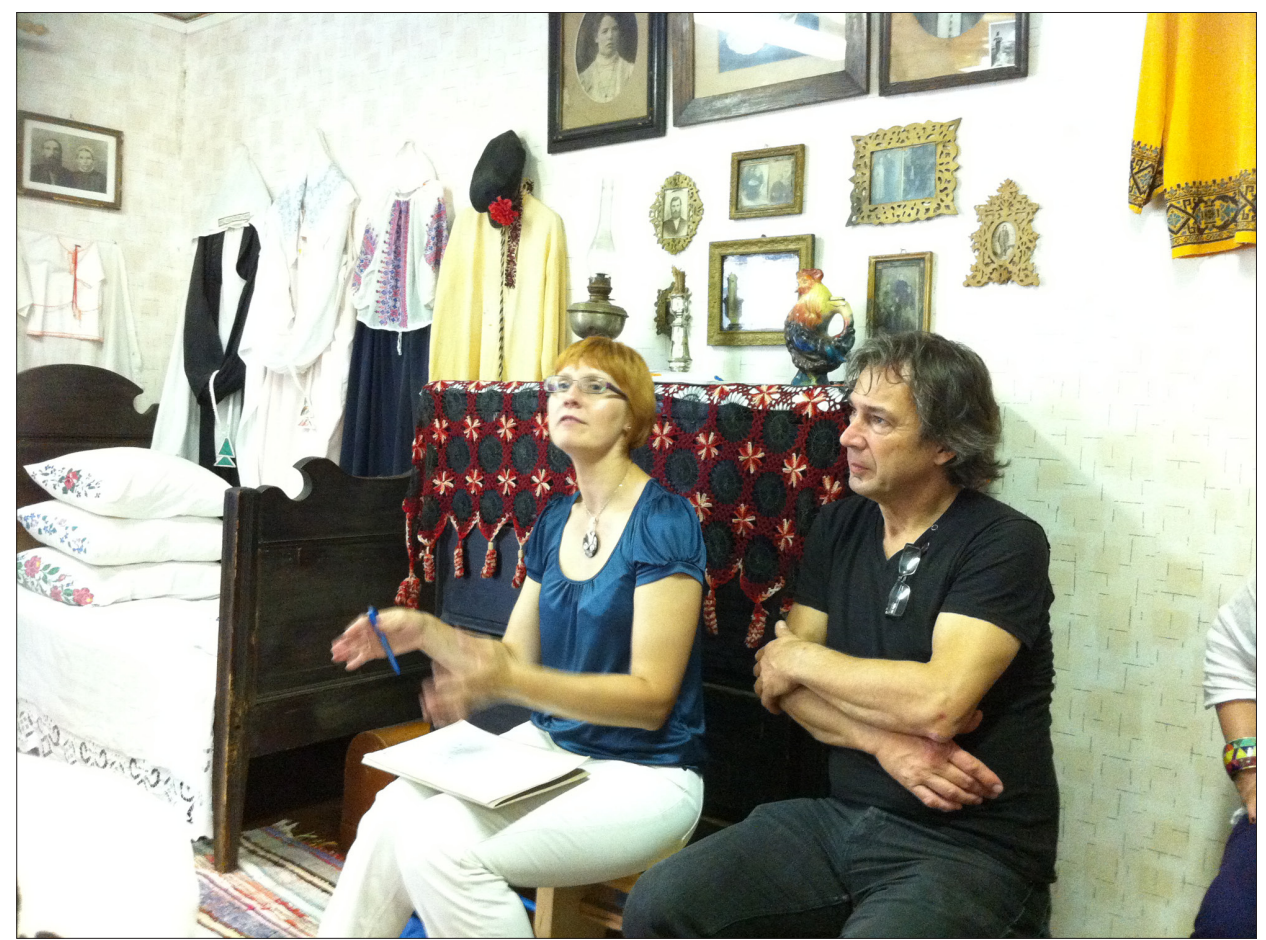

Figure 12. A visit to the ultra-Orthodox minority museum on the western shore of Lake Peipsi on 4 July 2013. Sitting on the right is Professor Peter Jan Margry from the SIEF secretariat in Amsterdam, Holland. Photograph by Kristina Gustavsson.

countries to participate in both congresses. The bus from Vilnius to Tartu in the weekend between the two congresses was fully booked and the journey provided an instructive opportunity to experience landscapes in large regions of the Baltic States.

During an excursion in connection with the SIEF congress in Tartu, we had the opportunity of meeting an ultra-Orthodox religious minority from Russia. Starting in the early 1700 s, the group had found refuge in the village of Räpina on the western shore of the long and narrow Lake Peipsi in south-eastern Estonia. The excursion participants also exhibited political interest in their eagerness to catch a glimpse of Lake Peipsi through which the border with Russia had run since 1991. We were also made aware of the local Estonian inhabitants' unease brought on by Vladimir Putin's show of political power on the other side of the lake. 
In conclusion I wish to emphasise that the purpose of this survey has been to demonstrate the expansive development that has taken place in Estonian ethnology and folkloristics during the more than twenty years that have passed since independence was regained in 1991. The re-construction of ethnology and folkloristics that has taken place after that has been fantastic. Contacts with the outside world, first with Scandinavia and later on also with the rest of Europe and the entire world have been extremely successful. A specific proof of this is that the small country of Estonia was entrusted first with the arrangement of an international ISFNR congress in 2005 and thereafter an international SIEF congress in 2013.

\section{REFERENCES}

Anepaio, Terje \& Jürgenson, Aivar 1998a. Eessõna. [Foreword.] In: Terje Anepaio \& Aivar Jürgenson (eds.) Kultuuri mõista pü̈̈des / Trying to Understand Culture. Tallinn: Teaduste Akadeemia Kirjastus, pp. 13-18.

Anepaio, Terje \& Jürgenson, Aivar (eds.) 1998b. Kultuuri mõista pü̈̈des / Trying to Understand Culture. Tallinn: Teaduste Akadeemia Kirjastus.

Annist, Aet \& Kaaristo, Maarja 2013. Studying Home Fields: Encounters of Ethnology and Anthropology in Estonia. Journal of Baltic Studies, Vol. 44, No. 2, pp. 121151. http://dx.doi.org/10.1080/01629778.2013.775846.

Ekholm, Curt 1984. Balt- och tyskutlämningen 1945-1946. [The Deportation of Baltic and German Military Internees in 1945-1946.] Uppsala: Studia Academiae Upsaliensis.

Elmevik, Lennart 2007. Minnesord den 6 november 2007. [Commemorative Speech on 6 November 2007.] Saga och Sed: Kungl. Gustav Adolfs Akademiens årsbok, pp. 11-18.

Frykman, Jonas 1988. Folklivsarkivet, frågelistorna och forskningen. [Folklore Archives, Questionnaires, and Research.] In: Nils-Arvid Bringéus (ed.) Folklivsarkivet i Lund 1913-1988: En festskrift till 75-årsjubileet. Lund: Skrifter från Folklivsarkivet i Lund, pp. 91-107.

Gustavsson, Anders 1987. The Finnish Settlers' Days as a Process of Revitalization. Arv: Nordic Yearbook of Folklore, pp. 59-71.

Gustavsson, Anders 1989. "Skogsfinnar": Några inblickar i ett nordiskt forskningsprojekt. ["Forest Finns": Some Insights in a Nordic Research Project.] Saga och Sed: Kungl. Gustav Adolfs Akademiens årsbok, pp. 85-98.

Gustavsson, Anders 1992. Inledning. [Introduction.] In: Anders Gustavsson (ed.) Kulturforskning i Tyskland och Norden. ETNOLORE 12. Uppsala: Etnologiska institutionen, pp. 7-21.

Gustavsson, Anders 1993a. Inledning. [Introduction.] In: Anders Gustavsson (ed.) Kulturforskning kring alkohol $i$ Norden. ETNOLORE 14. Uppsala: Uppsala universitet, pp. 7-17. 
Gustavsson, Anders 1993b. "Waldfinnen": Einblicke in ein nordisches Forschungsprojekt. In: Saulvedis Cimermanis (ed.) Colloquium Balticum Ethnographicum: Wege und Teilnehmer ethnisch-kultureller Kontakte in der Ostseeregion. Riga: Zinātne, pp. 24-37.

Gustavsson, Anders 1996. Exchange Trip to Tartu University, 9-14 March 1996. NIF Newsletter, Vol. 24, Nos. 2-3, pp. 7-9.

Gustavsson, Anders 1998. To Tell or Not to Tell: Relating to the Surrounding Power Situation. In: Terje Anepaio \& Aivar Jürgenson (eds.) Kultuuri mõista püüdes / Trying to Understand Culture. Tallinn: Teaduste Akadeemia Kirjastus, pp. 83-97.

Gustavsson, Anders 2004. Rituals around Unexpected Death. In: Ene Kõresaar \& Art Leete (eds.) Everyday Life and Cultural Patterns: International Festschrift for Elle Vunder. Studies in Folk Culture, Vol. 3. Tartu: Tartu University Press, pp. 206-238.

Gustavsson, Anders 2014a. Cycling as Innovation in Norway and Sweden: A Narrative Study of the Acceptance of a Technical Novelty. Open Journal of Social Sciences, Vol. 2, No. 1, pp. 72-85. http://dx.doi.org/10.4236/jss.2014.21009.

Gustavsson, Anders 2014b. Grave Memorials as Cultural Heritage in Western Sweden with Focus on the 1800s. Oslo: Novus Press.

Hellspong, Mats 1993. Etnologien i dagens Estland. [Ethnology in Today's Estonia.] Rig: kulturhistorisk tidskrift, Vol. 76, No. 1, pp. 5-10. Available at http://cts.lub.lu.se/ ojs/index.php/rig/article/view/5522, last accessed on October 28, 2015.

Hellspong, Mats \& Skott, Fredrik (eds.) 2010. Svenska etnologer och folklorister. [Swedish Ethnologists and Folklorists.] Acta Academiae Regiae Gustavi Adolphi CIX. Uppsala: Kungl. Gustav Adolfs Akademien för svensk folkkultur.

Kõresaar, Ene \& Leete, Art (eds.) 2004. Everyday Life and Cultural Patterns: International Festschrift for Elle Vunder. Studies in Folk Culture, Vol. 3. Tartu: Tartu University Press.

Mathisen, Stein R. 1990. Nordic Research Course in Finnskogen. Ethnologia Scandinavica, Vol. 20, pp. 147-148.

Pakosta, Liisa 1994. Förord. [Preface.] Nord Nytt: Nordisk tidsskrift for folkelivsforskning, No. 56, Estnisk etnologi, pp. 3-4.

Plaat, Jaanus 1999. Revivalist Movements and Changes in the Folk Religion and Everyday Life of the Estonian and Swedish Peasantry in Western Estonia in the 18th-20th Centuries. In: Anders Gustavsson \& Maria Santa Montez (eds.) Folk Religion: Continuity and Change. Lisboa \& Uppsala: Universidade Nova de Lisboa \& Uppsala Universitet, pp. 225-231.

Rogan, Bjarne \& Eriksen, Anne (eds.) 2013. Etnologi og folkloristikk: En fagkritisk biografi om norsk kulturhistorie. [Ethnology and Folkloristics: A Critical Biography of Norwegian Cultural History.] Oslo: Novus forlag.

Smidchens, Guntis 2014. The Power of Song: Nonviolent National Culture in the Baltic Singing Revolution. Seattle \& London: University of Washington Press.

Talve, Ilmar 2004. I Villa Lusthusporten hos professor Sigurd Erixon. [In Villa Lusthusporten with Professor Sigurd Erixon.] Saga och Sed: Kungl. Gustav Adolfs Akademiens årsbok, pp. 101-114.

Thomson, Clare 1991. The Singing Revolution: A Political Journey through the Baltic States. London: Michael Joseph. 
Vunder, Elle 1993. Über die Beeinflussung der estnischen Volkskunst durch das deutsche Kunsthandwerk. In: Saulvedis Cimermanis (ed.) Colloquium Balticum Ethnographicum: Wege und Teilnehmer ethnisch-kultureller Kontakte in der Ostseeregion. Riga: Zinātne, pp. 142-162.

\section{INTERNET SOURCES (all last accessed on November 19, 2015)}

http://www.geoatlas.com/en/maps/countries-4/estonia-1165

http://evm.ee/eng/home

https://sv.wikipedia.org/wiki/Måndagsrörelsen

www.folklore.ee/folklore/

www.folklore.ee/BIF/

www.folklore.ee/folklore/ksisu.htm\#rec

www.isfnr.org/index2.html

www.nordforsk.org

www.ne.se/uppslagsverk/encyklopedi/lång/baltutlämningen

www.ne.se/uppslagsverk/encyklopedi/lång/gustav-ränk

www.siefhome.org/congresses/sief2013/index.shtml

www.sprakochfolkminnen.se/folkminnen/samlingar/estlandssvenska-samlingar.html www.ut.ee/folk/index.php/en/department/history 


\section{TH INTERNATIONAL HUMOUR CONFERENCE AT HOLY NAMES UNIVERSITY, OAKLAND, CALIFORNIA, JUNE 29 - JULY 3, 2015}

In the summer of 2015, an international conference on humour studies took place at Holy Names University, where Professor Martin Lampert from the Department of Psychology, the long-serving secretary of the International Society for Humor Studies (ISHS), invited humour scholars from all over the world to hold their 27th annual meeting. This year, the conference featured more than 150 presentations, workshops, and performances from scholars and professionals representing 26 countries. The dense programme was generally targeted at five areas: 1) cognition and creativity; 2) culture, gender, and community; 3) health and well-being; 4) individuals and individual styles; and 5) public and private discourse. In addition to that, there were five panels / general sessions, sponsored symposia by renowned associations and societies dealing with humour, some roundtables (e.g. teaching humour studies at university), workshops, and plenty of extracurricular activities.

The general sessions, the first of which dealt with judiciary humour, featured Christie Davies (University of Reading, UK), Marc Galanter (University of Wisconsin Law School, US), and attorney Pamela Hobbs (US). The discussion touched upon the uses of humour in courts, especially from a cross-cultural perspective, with examples given mostly from the court practices of Great Britain and the Unites States. The last speaker, Dr Hobbs, pointed out that quite often the use of humour is connected with illustrating a thought to elucidate a law, as humour has the ability to make explanations more memorable and digestible, even if at the same time it makes them more ambiguous. Another thought-provoking general session was on cross-cultural perspectives on women in stand-up comedy, chaired by Sharon Lockyer (Centre for Comedy Studies Research, Brunel University, UK), held on the third day of the conference. It started with a presentation from Dr Lockyer and continued with an overview of women comedians from around the world, as the other speakers talked about women's stand-up in Japan (Kimi Oshima, Kanagawa University) and the United States (Regina Barreca, University of Connecticut). Generally, it can be said that in recent years the Western stand-up comedy scene features more female comedians than before and this trend is rising. The same goes for female rakugo performers in Japan (rakugo being a tradition of comic storytelling in which the performer sits on the stage and acts out a humorous narrative (quite often in dialogic format) without any other props than just a paper fan and a small cloth). Yet another very successful general session was on cognitive science, chaired by Graeme Richie (University of Aberdeen, UK). The first presenter, Seana Coulson (University of California, US) suggested that, in order to fully understand a visual-textual joke, the audience needs to be familiar with the evolution of the joke and see the different layers of meaning and reference, at least to some extent. Tony Veale (University College Dublin, Ireland) continued with irony in rule-based generative systems or automatic 
'joke machines'. He argued that it is actually the audience that reads the information into the text, and their set of previous knowledge does not have to coincide with that of the humour creator, in this case - a computer programme. People look for newness, and putting old, recognisable elements into a novel context is a key to creativity and art - and quite often also to humour. He also referred to the paradox inherent in the attempts to bring together computers and humour: How can we build a rule-based system (a computer script) that can break the rules?

Sponsored symposia were centred around introducing the various associations dealing with humour and its applications: the Japanese Society for Laughter and Humor Studies (with a fascinating discussion about catastrophe humour, comparing its main features in Japan and in the United States); the Association for the Study of Play (talking about the positive effects that humour can have, e.g. in language learning, but also the darker side, e.g. bullying and teasing); the International Society for Luso-Hispanic Humor Studies, the Observatoire de l'Humour in Canada (giving a much-needed insight into French-language humour industry); the European Journal of Humour Research (bringing together research on humour and nationally specific communication styles); the Israeli Society for Humor Studies, the Association for Applied and Therapeutic Humor, and the American Humor Studies Association. The (growing) number of these associations and the wealth of topics that they cover give evidence of the versatility and vitality of the field.

As already mentioned, there were more than 150 paper presentations at the ISHS annual conference, divided into three parallel sessions over four and a half days. To mention only a few, Ayesha Ashfaq (University of Punjab Lahore, Pakistan) and Joshua L. Moss (University of California, US) presented their papers in the session called Humour in the Global Media, and initiated a polemical discussion on the role of and right to joke in the globalising world. The first speaker stressed the need for political correctness and formulated a set of rules for journalists and cartoonists in order to avoid international conflicts. Moss focused more on the process and not so much on the reception of humour, and blamed the missing context for causing what he called transnational humour controversies. Generally speaking, humour illuminates boundaries and elucidates them where they were hidden before. Worth noting is Elliott Oring's (California State University, US) critical presentation on so-called benign violations theory created by Peter McGraw and his team, which has received great media coverage but has been built on just a few doubt-raising studies and premises. Oring called upon researchers to check the evidence for their theories and thus contribute to a stronger academic validity of the field.

A good selection of workshops included a fast insight into Paul McGhee's humour intervention programme (The 7 Humor Habits Program), in which the author introduced the inner workings of his system and advocated for the daily use of small humour-related and humour-enhancing tasks.

The first conference day ended with a roundtable discussion of humour in animation art. People from Pixar Animation Studios and Cartoon Art Museum in San Francisco (Craig Good, Austin Madison, Jeff Pidgeon, Christian Roman, and Andrew Farago) spoke about creating visual humour. Their recent reference point was the animated movie Inside Out (2015), and although no visual examples were demonstrated to the public, 
the discussion showed vividly that any humorous text has to contain a balancing amount of other emotional aspects in order to have an effect on the audience.

In addition to the academic programme, Dr Lampert had compiled an extremely varied and enjoyable evening programme, with the traditional ISHS joke-telling competition (this year unanimously won by the talented joke-teller and long-time ISHS member Joyce Saltman), and numerous other exciting events like an improv competition, stand-up comedy competition, and the play titled Lend Me a Tenor. Of these, the improv competition definitely deserves a mention as the most entertaining and professionally delivered one. The winner, Made Up Theatre from San Francisco, unfolded an unforgettable story of the importance of imaginary friends before the very appreciative audience, receiving the loudest applause and highest points of the jury.

The strong academic programme and amusing social events combined with the breath-taking views from the Oakland Hills overlooking the San Francisco-Oakland Bay Area made for a great conference. The next ISHS conference will take place in Dublin, Ireland, on June 27- July 2, 2016, under the title Humour as Embodied Practice, and will be hosted by Professor Eric Weitz from the Department of Drama, in partnership with the Trinity Long Room Hub, and with support from Fáilte Ireland.

Liisi Laineste 


\section{BOOK REVIEWS}

\section{MINING CORPORATION AND LOCAL COMMUNITIES IN INTERACTION: THE CASE OF BATU HIJAU}

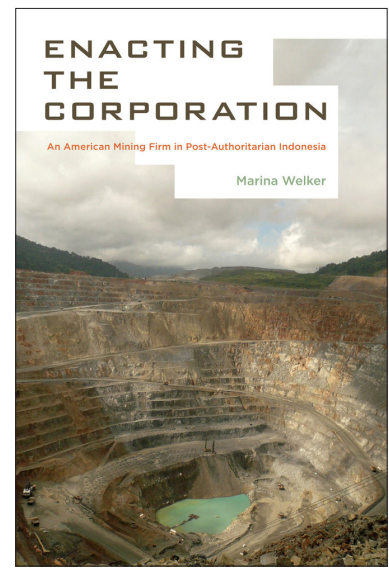

Marina Welker. Enacting the Corporation: An American Mining Firm in Post-Authoritarian Indonesia. Berkeley \& Los Angeles \& London: University of California Press, 2014. 289 pp.

As noted in the report of the United Nations Research Institute for Social Development (UNRISD) in 1995, “... rapid socio-economic changes in the second half of the 20th century brought many [people] an improvement of life, but there are millions who did not receive any benefits" (Trevogi mira 1997: 24). On the contrary, they experienced a negative impact as a result of the developing infrastructure of global economy, focused on meeting the growing demand for goods and services in developed countries.

The monograph from anthropologist $\mathrm{M}$. Welker of Cornell University (Ithaca, NY) contributes to the development of scientific understanding on the practice of interaction between large mining corporations and local communities, from the point of view of socio-cultural anthropology. Based on the outcomes of a two-year research into the areas of development of copper and gold deposits of the US corporation Newmont (Denver, US) in the Batu Hijau region (in the south-western part of the island of Sumbawa, Indonesia), the author draws a broad panorama of the perceptions with regard to the company by the local population, who are mainly Muslim and predominantly agrarian in their original economic specialisation. She also studies the interactions that arise between the parties, problems in their relationship, and Newmont's targeted policies to resolve them (which are particularly valuable).

During the period of development of mineral deposits on Sumbawa Island (since the mid-1990s until present), the Newmont company has acquired considerable experience in working with local communities and their integration into the corporate space; reaching, as a result, a reduction of social and ethnic tension. By virtue of the purposeful policy of Corporate Social Responsibility (CSR), and a variety of implemented measures in this regard, the author outlines that the company generally managed to resolve the underlying problems that caused various kinds of protests from the local community (violent and aggressive rhetoric of national and religious rejection), which were characteristic of the period of the start of mining operations. As a result, they can proceed towards the design of new vectors for local socio-economic development on the basis of the US corporation, its infrastructure, and its support. In synchronisation with this process, the degree of discontent with the presence of a foreign company and a large contingent of foreign experts and employees on the land of the local residents gradually 
decreased. The desire for cooperation strengthened, and also some new ideas formed in the public consciousness of aborigines who gradually began to associate the feeling of stability of local communities (including their economic, social, and even cultural aspects) with the presence of a mining company in the area. How was Newmont able to achieve such an effect?

According to the main part of the monograph, Welker gradually reviews various mechanisms of the mutual adaptation of the foreign company and the indigenous communities of Sumbawa Island. It is significant that it is the corporation itself that had to change in the first place, including the top level of decision-making. The first chapter, titled We Need to Newmontize Folk: New Social Disciplines at Corporate Headquarters (pp. 33-66), provides a detailed analysis of changes in the company's management and its interactions with the external environment in the initial period of operation of the extractive industries in the south-western part of Sumbawa Island. This included measures such as the extension of power and budget for corporate services responsible for communication with local communities, focus on getting a Social License to Operate and a further annual holding of social impact assessment (SIA). On the one hand, these actions are significant as they entail unprecedented measures to counteract racist and anti-Muslim sentiment among the American employees of the corporation, and on the other hand they attempt to adapt the working environment and the company's infrastructure to the cultural and religious needs of its employees - Muslims employed in the region of extraction (up to the organisation of specially equipped places for namazprayer in mining areas).

Welker mentions that originally there existed two opinions with regard to the question of what should be the approach to organising effective support to local communities. The following shows that both of them successively competed in the practical activities of the company.

The first approach is based on the patronage model of interaction (reviewed in the second chapter, Pak Cormel Is Our Regent Whom We Respect: Mine, State and Development Responsibility, pp. 67-98), in which the company assumes a greater part of the responsibility for the maintenance of social infrastructure, the economic development of local communities, funding of cultural programmes, construction of mosques and religious schools, etc. However, the duty of the corporation lies only in providing sufficient funding, and local elites - acting as intermediaries between the company management and local people - allocate the funds. This so-called patronage approach, involving the mediation with local elites, is essentially based on the traditional foundations of social organisation of indigenous communities without disturbing the historical practices of the distribution of social and material wealth and resources.

The other approach, called the sustainable development model, is rather different and oriented towards the perspective of sustainable development of local communities, described in detail in Chapter 3, under the heading My Job Would Be Far Easier If Locals Were Already Capitalists: Incubating Enterprise and Patronage (pp. 99-128). This approach is about the attempts of corporations (by making use of their resources) to lay a foundation for long-term independent economic development of groups of the local population, with the potential of continuation after the completion of the regional mining activities. In this direction, Newmont has implemented extensive training programmes on the basics of modern business for local residents, in order for them to develop neces- 
sary business skills. This part of Welker's monograph includes interesting facts that give credence to the special approach the managers of the organisation brought to the training sessions with the potential (mainly Muslim) entrepreneurs. To facilitate the 'immersion' of students in the semantic space of individual entrepreneurship - the free market and competitive business - the company decided to include religious lectures in the classroom. The essence of these lectures was the justification - including quotations from the Koran - with regard to the rights of Muslims and their need for doing business.

Educational work was also carried out among the local farmers in an attempt to introduce them to effective technologies of agriculture and thus contribute to the growth of the subsistence level (Chapter 4, We Identified Farmers As Our Top Security Risk: Ethereal and Material Development in the Paddy Fields, pp. 129-156).

Evaluating the effectiveness of the two models that were employed by the company for local community support, Marina Welker concludes that the managers of Newmont did not manage to actually run the programme for sustainable development. The reason for that was the unwillingness of many participants of the programme to positively regard the neo-liberal idea of independent development. However, any manifestation of patronage on the part of the corporation was perceived among the local populations as something more familiar. The reason is that it fits quite well with the basis of traditional social organisation (including the elements of clan structure) and the traditions of the local communities in the area of distribution of socially significant resources (with a leading role in this process for local elites). It is worth mentioning that this seems to be the logical manifestation of stability for Potestarian traditional cultures that emerge full-blown among indigenous peoples in such situations. Related examples can be found among the peoples of southern Siberia, or rather their individual rural communities, who are included in the negotiations with mining companies or energy-sector enterprises on the issue of the required compensation for damages incurred by the indigenous communities (Etnologicheskaia Ekspertiza 2005).

In the next chapter (Corporate Security Begins in the Community: The Social Work of Environmental Management, pp. 157-182) the author evaluates the discourse that ensued between the Newmont company, local communities, and environmental organisations on the issue of environmental safety of the technologies used in copper and gold mining in the immediate vicinity of human settlements and vulnerable ecosystems. From Welker's point of view, it is a successful demonstration of a mining company conducting its operations with a minimum of harm to the environment, which became an important step in the fight against attempts to demonise Newmont. Its evaluation in the social consciousness of local residents gradually evolved from 'Newmonster' to 'Goodmont'. In that way another significant source of tension was neutralised. However, during the start of the Newmont project in the region of Batu Hijau it caused real concerns for local communities, which in turn increased the discourse of conflict.

The final, sixth chapter of the book (We Should Be Like Starbucks: The Social Assessment, pp. 183-214) discloses the practice of continuous monitoring of the social impact of the company on the local communities, thoroughly analysing the selection process of social auditors, systematic check-ups of the effectiveness of corporate social responsibility policies and procedures on the public discussion of its actual agenda.

The material presented in the book by Marina Welker, Enacting the Corporation: An American Mining Firm in Post-Authoritarian Indonesia, is particularly interesting 
in a comparative context. In fact, it features a qualitatively described case, revealing a complex system of relations between a large mining corporation on Sumbawa Island and the local indigenous communities. Techniques, problems, and results of these relations are not only described in detail by the author, but analysed with enough detail from the perspective of the socio-anthropological approach.

A comparison between the practices presented in this book and the reality of relations between indigenous peoples and mining companies in other parts of the world including, for instance, the circumpolar territories - seems extremely promising to me.

Vladimir Poddubikov

Kemerovo State University / Moscow State University

\section{Acknowledgement}

The review was written in the framework of the project, "The resource curse in the circumpolar areas: Russian and international experience in the field of analysis and resolution of conflicts over non-renewable resources in areas traditionally inhabited by indigenous ethnic groups" (RSCF, grant No. 15-18-00112, PI prof. Dmitri Funk).

\section{References}

Etnologicheskaia ekspertiza 2005. Vypusk 1. Otsenka vozdeistviia OOO MetAl, OAO MMK - Magnitogorskii metallurgicheskii kombinat i UK Iuzhnyi Kuzbass (stal'naia gruppa Mechel) na sistemy zhizneobespecheniia avtokhtonnogo i russkogo naseleniia Chuvashskoi sel'skoi administratsii MO g. Myski Kemerovskoi oblasti. [Ethnological Expert Examination. Issue 1. Estimation of MetAl Company (Magnitogorsk Metallurgy Plant) and Southern Kuzbass Coal Company (Mechel Steel Group) Influence on the Traditional Subsistence Systems of the Indigenous People and Russian Population of Chuvashenskaya Local Authorities (Town Myski, Kemerovo Region).] Kemerovo: Skif.

Trevogi mira 1997. Sotsial'nye posledstviia globalizatsii mirovykh protsessov. Doklad IuNRISD, podgotovlennye dlia Vsemirnoi vstrechi na vysshem urovne v interesakh sotsial'nogo razvitiia. [States of Disarray: The Social Effects of Globalization. Executive Summary of an UNRISD report for the World Summit for Social Development.] Moscow: Institute of Ethnology and Anthropology (RAS). 


\title{
NORTHERN CULTURES UNDER THE PRESSURE OF INDUSTRIAL DEVELOPMENT
}

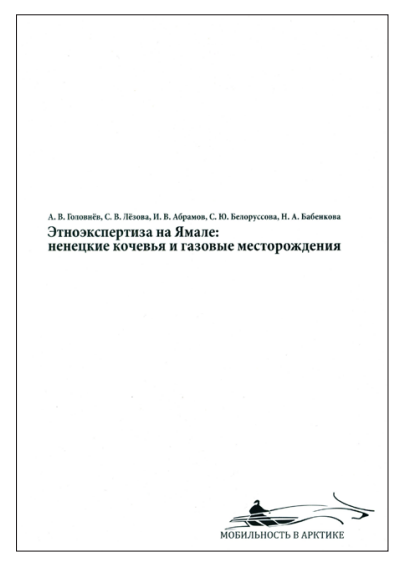

\author{
A. Golovnev \& S. Lezova \& I. Abramov \& S. Belorussova \\ \& N. Babenkova. Etnoekspertiza na Iamale: Nenetskie \\ kochev'ia i gazovye mestorozhdeniia. [Ethno-Expertise \\ on the Yamal Peninsula: Nenets Pastures and Gas \\ Fields.] Ekaterinburg: Izdatel'stvo AMB, 2014. 232 pp. \\ In Russian.
}

There exists a wide variety of literature devoted to the role of the oil and gas industry in post-Soviet Russia, which includes not only scientific research on the impact of oil development on the Northern peoples (see, e.g., some recent works: Wiget \& Balalaeva 2010; Stammler 2013; Stammler \& Wilson 2006; Wiget \& Balalaeva 2014; Sirina \& Iarlykapov \& Funk 2008; Khaknazarov 2011; Novikova 2014; Miskova 2014, and others), but also works in line with the so-called ethnological expertise. Although there exist a number of typically Russian well-known features (see, e.g., Bogoyavlensky et al. 2002; Zvidennaia \& Novikova 2010; Martynova \& Novikova 2012), the latter in general fit into the generally accepted understanding of the scientific and practical research defined as a part of applied anthropology and anthropology of development.

The presented collective research refers to the genre of Russian works on "ethnological expertise" (basically known in the anthropological practice as social impact assessment), but at the same time has its own features that make this work worthy of special attention.

The book Ethno-Expertise on the Yamal Peninsula: Nenets Pastures and Gas Fields is written by Andrei Golovnev, a renowned specialist on the culture of the North - in particular Samoyed cultures - in collaboration with his students, members of the Institute of History and Archaeology of the Ural Branch of the Russian Academy of Sciences. The results of an actual expertise carried out in the area of geological exploration in the territory of the Kruzenshtern gas field (on the western coast of the Yamal Peninsula, July-August 2013) and the subsequent report that was prepared based on its results, lie at the heart of the reviewed work. As noted in the introduction, the report - quite acceptable for experts - would be too impenetrable for the general reader. In this regard, the authors decided, on the one hand, to greatly facilitate the language of the text, while on the other hand to talk not only about the results of the work, but also about the course of the research. The authors were perfectly able to reach their goals. The book is easy to read (you can say in one sitting) and a great number of colour illustrations (over 60), charts, and maps contribute to this greatly.

This collective monograph, which is how one could define the genre of this work, consists of two parts virtually equal in volume: the research itself (Kochevniki $i$ nedropol'zovatel $i$ (Nomads and mineral developers), pp. 12-107) and appendices (Istochniki i bazy dannykh (Sources and databases), pp. 108-223).

There are four chapters in the research part of the work that are presented successively: the context of carrying out the expert evaluation, description, and analysis of 
the boundaries of nomads and specifics regarding the organisation of Nenets' nomadic cultures, the "voice of the tundra" (statements of indigenous peoples about the future industrial development of their lands), and foresight reflections of the authors.

The presented work wins the reader over with the abundance of recent field data and the actual voices of people whose problems are being discussed. The use of several methods of fixing/describing the movement of herders, GPS-recordings of human movement during the day, maps of nomadic migrations (with annual coverage of the process) and the footage of movements/actions including photographic and video material (p. 56) should be highlighted among the authors' undisputed research achievements. A similar technique has already been used in the Russian field (Safonova \& Sántha 2013a; Safonova \& Shanta $2013 \mathrm{~b}$ ), but in relation to the Nenets it seems that indeed it has been used for the first time.

The final chapter of the main part of the book includes scenarios and recommendations. It represents the main factors of pessimistic (pp. 99-100) and optimistic (pp. 100102) scenarios, as well as recommendations on compensation (pp. 102-103, 106-107), largely based on the "Declaration of co-existence of indigenous peoples and the oil \& gas industry in the Nenets and Yamal-Nenets autonomous regions and other territories of the Russian North", generated by our colleagues from the Arctic Centre, University of Lapland, in the years $2007-2008 .{ }^{1}$

The section of appendices to the book includes a general characterisation of historical sources, a short story about the traditions of the nomads on the Yamal Peninsula, and an essay presenting analogues of ethnological expertise of recent times in Russia (as performed by the staff of the Institute of Ethnology and Anthropology of the RAS) and abroad (project ENSINOR). The section also contains characteristics of the legal framework with regard to indigenous peoples in the Russian Federation and the YamaloNenets region in particular, and a thorough analysis of the situation with regard to the cultural heritage of the indigenous peoples of the North (pp. 108-143). In addition, the section of appendices is completed by unique primary materials of the 1926-1927 census of the indigenous population of Yamal, which is the first time ever for these materials to appear in print (pp. 143-223). The latter appendix is extremely informative, although without comments or analysis or a description of the logic of how this document refers to the contemporary problems of herders caused by the industrial development of the tundra, it remains, in my opinion, an independent text in the book.

There are at least two more general observations to be made on the provided expertise, which emerge within the context of broad reflections on the status of expert-analytical works of Russian ethnologists.

The text presented for the judgment of colleagues (as a result of the expertise) was created incidentally: this "ethological expertise" was not ordered by industrial companies, local authorities, or by public organisations of the Nenets. Ethnologists were simply invited (p. 9) by ecologists, who conducted their own environmental expertise in the above-mentioned area of the Yamal Peninsula. This clearly describes the situation of "ethnological expertise" in Russia, whose necessity and rules of conduct have remained without legislative consolidation and regulation on the federal level for about 15 years. ${ }^{2}$

There is another problem, which is closely associated with the one above: The ethnologists participating in the project considered "the possible consequences of geological exploration without any clear picture of the planned industrial development of the ter- 
ritory" (p. 15). The lack of plans for industrial development "complicated the expertise, forcing to guess about the scale of industrial invasion which they would have to deal with" (ibid.). The legislative optionality of the ethnological expertise and its informal nature led to inability to obtain the required documents and extremely complicated the task of the experts. As a result, an attempt was made to assess the possible consequences of such development on the territory of the Kruzenshtern gas field "by analogy", by focusing on the already existing models of industrial impact on the Yamal tundra.

Through trial and errors Russian applied anthropology is trying to find entrance into the world of uneasy relations between science and the state, business, and local populations, which live in the impact zone of management decisions on a daily basis. There is no doubt that the collective monograph Ethno-Expertise on the Yamal Peninsula: Nenets Pastures and Gas Fields with its advantages and some, perhaps, controversial approaches is a useful step in this progressive process. This book will be of interest to all those involved in the cultures of the reindeer herders of the circumpolar world and in research in the field of applied and public anthropology.

\author{
Dmitri Funk \\ Moscow State University / Tomsk State University
}

\title{
Acknowledgement
}

The review is written within the framework of the project "The resource curse in the circumpolar areas: Russian and international experience in the field of analysis and resolution of conflicts over non-renewable resources in areas traditionally inhabited by indigenous ethnic groups" (RSCF, grant No. 15-18-00112).

\section{Notes}

1 See description of the project ENSINOR on the site of the Arctic Centre of the University of Lapland, Finland (http://www.arcticcentre.org).

2 About 15 years since the term was used for the first time in the legislation of the Russian Federation. It appeared in the law "On the guarantees of the rights of indigenous peoples of the Russian Federation", adopted in 1999.

\section{References}

Bogoyavlensky, D. \& Martynova, E. \& Murashko, O. \& Khmeleva, E. \& Yakel, Y. \& Yakovleva, O. 2002. Opyt provedeniia etnologicheskoi ekspertizy: otsenka potentsial'nogo vozdeistviia programmy OAO “Gazprom" poiskovo-razvedochnykh rabot $v$ akvatoriiakh Obskoi $i$ Tazovskoi gub na komponenty ustoichivogo razvitiia etnicheskikh grupp maloschislennykh narodov Severa. [The experience of ethnological expert evaluation: Assessment of the potential impact of the 
programme of "Gazprom" exploration in the waters of the Ob and Taz Bays on the components of the sustainable development of ethnic groups of indigenous peoples of the North.] Assotsiatsiia korennykh malochislennykh narodov Severa, Sibiri i Dal'nego Vostoka.

Khaknazarov, S. 2011. Kompensatsionnye vyplaty v aspekte sociologicheskikh issledovanii: na primere Surgutskogo raiona KhMAO - Iugry. [Compensation in the aspect of sociological research: The example of the Surgut district of Khanty-Mansiysk autonomous region - Yugra.] Vestnik ugrovedeniia, Vol. 4, No. 7, pp. 106-112.

Martynova, E. \& Novikova, N. 2012. Tazovskie nentsy $v$ usloviiakh neftegazovogo osvoeniia: Etnologicheskaia ekspertiza 2011 goda. [Taz Nenets in terms of oil and gas development: Ethnological expertise 2011.] Moskva: Institut etnologii i antropologii im. N.N. Miklukho-Maklaia RAN.

Miskova 2014 = Mis'kova, Elena. Review: Behrends Andrea, Reyna Stephen P., and Günther Schlee (eds.) Crude Domination: An Anthropology of Oil. New York \& Oxford: Berghahn Books, 2011. Sibirskie istoricheskie issledovaniia, No. 4, pp. 104110. Available at http://journals.tsu.ru/siberia/\&journal_page=archive\&id=1175, last accessed on October 8, 2015.

Novikova, Natalia 2014. Okhotniki i neftaniki: issledovanie po iuridicheskoi antropologii. [Hunters and oilmen: A research in legal anthropology.] Moskva: Nauka.

Safonova, Tatiana \& Sántha, Istvan 2013a. Culture Contact in Evenki Land: A Cybernetic Anthropology of the Baikal Region. Leiden \& Boston: Global Oriental.

Safonova, Tatiana \& Shanta [Sántha], Istvan 2013b. Vsyrechi na evenkiiskoi zemle: kiberneticheskaia antropologiia baikal'skogo regiona. [Meetings on the Evenki land: A cybernetic anthropology of the Baikal region.] Saint Petersburg, Aletheia.

Sirina, A. \& Iarlykapov, A. \& Funk D. (eds.) 2008. Neft', ekologiia, kul'tura. [Oil, Ecology, Culture.] Etnograficheskoe obozrenie, No. 3, pp. 3-108.

Stammler, Florian 2013. Oil without Conflict? The Anthropology of Industrialisation in Northern Russia. In: A. Behrends \& S. Reyna \& G. Schlee (eds.) Crude Domination: An Anthropology of Oil. New York \& Oxford: Berghahn Books, pp. 243-269.

Stammler, Florian \& Wilson, Emma 2006. Dialogue for Development: An Exploration of Relations between Oil and Gas Companies, Communities, and the State. Sibirica, Vol. 5, No. 2, pp. 1-42.

Wiget, Andrew \& Balalaeva, Olga 2011. Khanty, People of the Taiga: Surviving the Twentieth Century. Fairbanks: University of Alaska Press.

Wiget, Andrew \& Balalaeva, Olga 2014. Neft', marginalizatsiia i vostochnye khanty. [Oil, Marginalization, and the Eastern Khanty.] Sibirskie istoricheskie issledovaniia, No. 4, pp. 38-72. Available at http://journals.tsu.ru/siberia/\&journal_ page $=$ archive\&id $=1175$, last accessed on October 8, 2015.

Zvidennaia, O. \& Novikova, N. 2010. Udegeitsy: okhotniki i sobirateli reki Bikin (Etnologicheskaia ekspertiza 2010 goda). [Udege people: Hunters and gatherers of the Bikin River (Ethnological expertise 2010).] Moskva: Institut etnologii i antropologii im. N.N. Miklukho-Maklaia RAN. 


\section{OUR AUTHORS}

Elif Boyacıoglu is a $\mathrm{PhD}$ candidate at the Department of History, Bilkent University, in Ankara, Turkey. She received her MA focusing on the folkloric belief of the revenant in Great Britain from Bilkent University. Her main fields of research include primarily the perceptions of death, folkloric beliefs surrounding the dead and death, and rites of passage.

boyacio@bilkent.edu.tr

Toms Kencis is a folklorist, researcher at the Archives of Latvian Folklore at the Institute of Literature, Folklore and Art, University of Latvia. His research interests concern fields of knowledge and cultural production, paying special attention to disciplinary history, cultural nationalism, fine arts, and verbal charms.

toms1985@gmail.com

Evangelos Avdikos is professor of folklore at the Department of History, Archaeology, and Social Anthropology, University of Thessaly (Greece). He teaches oral narrative, supernatural stories (legends, curses, vampires), and rituals, and his research interests focus on folktales, fables, riddles, proverbs, cultural identities, and oral history.

avdikos@uth.gr

Véronique Campion-Vincent belongs to the French CNRS (Centre national de la recherche scientifique - National Centre of Scientific Research). For thirty years she has been studying rumours and urban legends, treating these phenomena as sociological and anthropological facts.

campionv@msh-paris.fr

Valentina Kharitonova, Candidate of Science in folkloristics (1983) and Doctor of Science in ethnology (2000), is leading a group of medical anthropology at the Institute of Ethnology and Anthropology, Russian Academy of Sciences, Moscow. She is President of the Association of Medical Anthropologists, and editor-in-chief of Medical Anthropology and Bioethics journal. She has published several books and over 300 articles on EastSlavic and indigenous Siberian spiritual beliefs and practices, folklore, and medical anthropology.

medanthro@mail.ru,Valkharit@iea.ras.ru

Anders Gustavsson was professor of cultural history at the Department of Cultural Studies and Oriental Languages, University of Oslo, in 1997-2010, and senior professor beginning in 2011 . His research has concerned popular religion, popular movements with emphasis on temperance and revivalist movements, coastal culture, cultural meetings, tourism, border cultures, rites of passage, gravestone symbolism, memorial internet websites, popular paintings, fieldwork, and methodology.

anders.gustavsson@ikos.uio.no 
Brigitta Davidjants received her MA degree in musicology from the Estonian Academy of Music and Theatre in 2007. Currently she is affiliated with the Estonian Academy of Music and Theatre where she examines how cultural policy is created and preserved, how 'Armenianness' is presented, and how music can be related to self-identification of a nation, geopolitics, and unequal power relations. She is also the founder of the Armenian folk ensemble Atlas.

brigitta.davidjants@gmail.com

Carme Oriol is a full-time university professor of Catalan Philology and Folk Literature and director of the Arxiu de Folklore at the Universitat Rovira i Virgili (Tarragona, Spain). She has conducted fieldwork in Andorra and Catalonia. Her research interests include folk narrative and the history of folklore. Several years she has been working with the projects "The Catalan Folktale Catalogue" and "Bio-bibliographic Collection of Popular Catalan Literature". She is co-author of the book Index of Catalan Folktales (Oriol \& Pujol 2008).

carme.oriol@urv.cat

Askhat Mayemirov is assistant professor at the Department of Acting Skills and Directing at the Kazakh National Academy of Arts named after T. Zhurgenov. His scientific interests include theatrical directing in Kazakhstan, the method of M. Chekhov, and the energy of acting. In 2010 he defended his MA thesis at the Russian Academy of Theatre Arts (GITIS), under the heading "Verfremdungseffekt and Aesthetics of Epic Theatre Brecht in Modern Directing". His doctoral studies at the Kazakh National Academy of Arts focus on theatre directing in Kazakhstan, continuity and innovation (1991-2015).

askhatmaemirov@mail.ru

Kabyl Khalykov is $\mathrm{PhD}$, professor, and Vice-Rector for Research at the Kazakh National Academy of Arts named after T. Zhurgenov. He has authored a book titled Stage Design, Contemporary Art and Cultural Politics of Kazakhstan in 1990-2000. He has also published a book-length study about the reflection of a person's essence and the human being in art, as well as several essays and articles, monographs devoted to philosophical anthropology and philosophy of cultures, titled Reflection of the Essence of Person in Art (2005), and The Problem of Human Being in Contemporary Art (2009).

kabylkh@gmail.com

Bakhyt Nurpeis, $\mathrm{PhD}$, is Dean of the Art Studies Faculty of the Kazakh National Academy of Arts named after T. Zhurgenov. She has authored two books: "Kazakhstan's Youth Theatre" and "Stages of Formation and Development of Kazakh Directing (1915-2005)". Bakhyt Nurpeis has also published more than a hundred articles devoted to actual problems of the Kazakh theatrical art.

bakytn_70@mail.ru 
Mehari Yimulaw Gebregeorgis is a post-doctoral fellow at the Institute for Dispute Resolution in Africa, University of South Africa. His research areas in the past three years have been traditional conflict resolution mechanisms and gender studies.

mehariymulaw@yahoo.com 

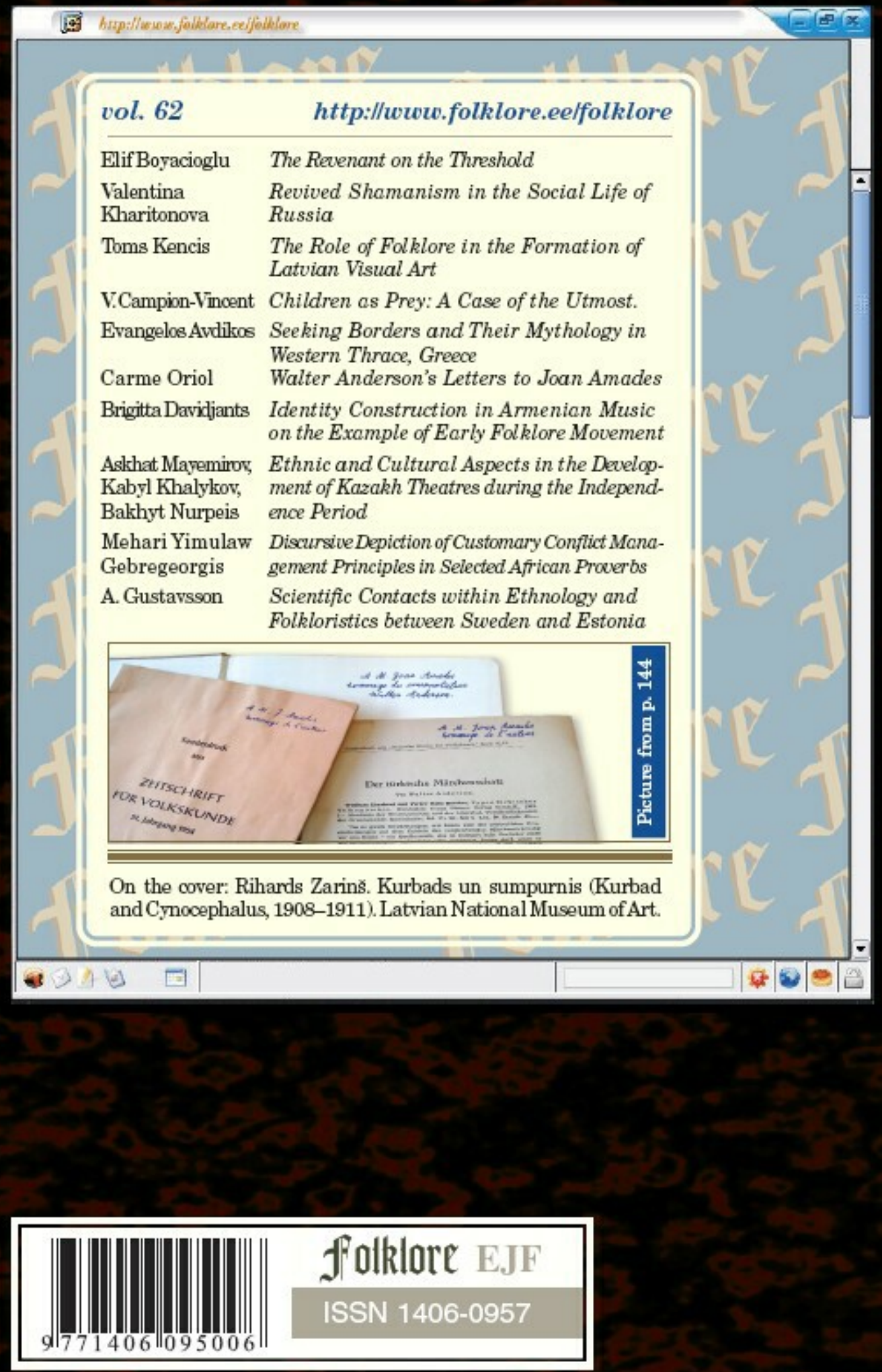